\title{
Membuat Berbagai Grafik dengan STATCAL
}

\section{(31 Menu Grafik)}

Diperbaharui: 18 Oktober 2018

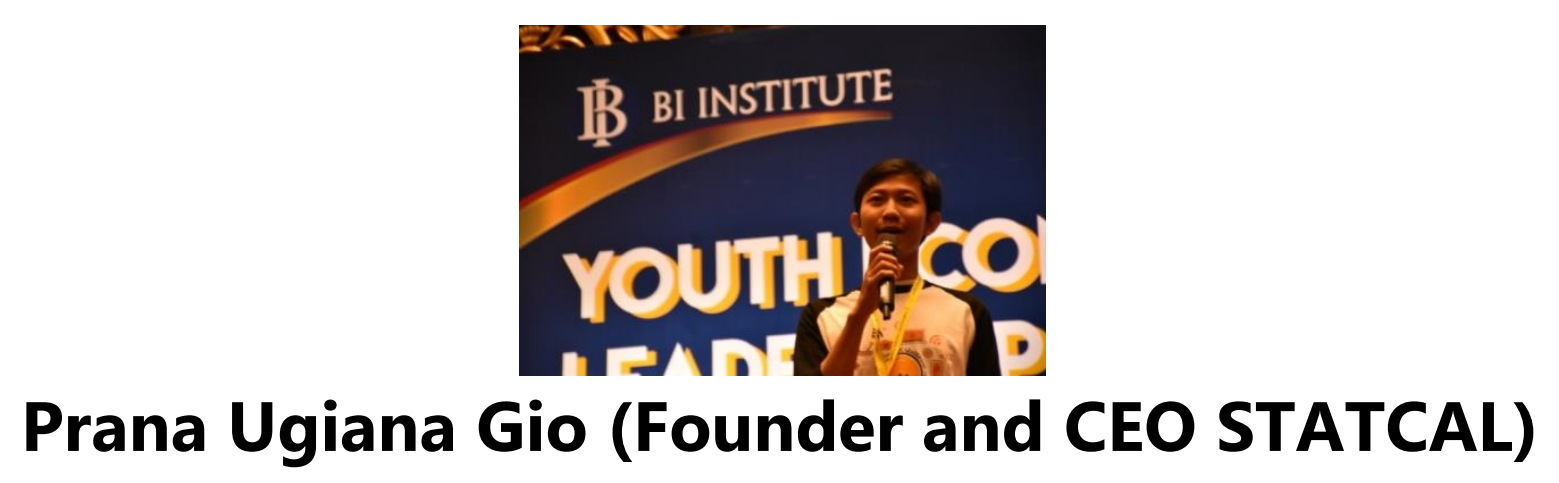

Download STATCAL di: WWW.statcal.com

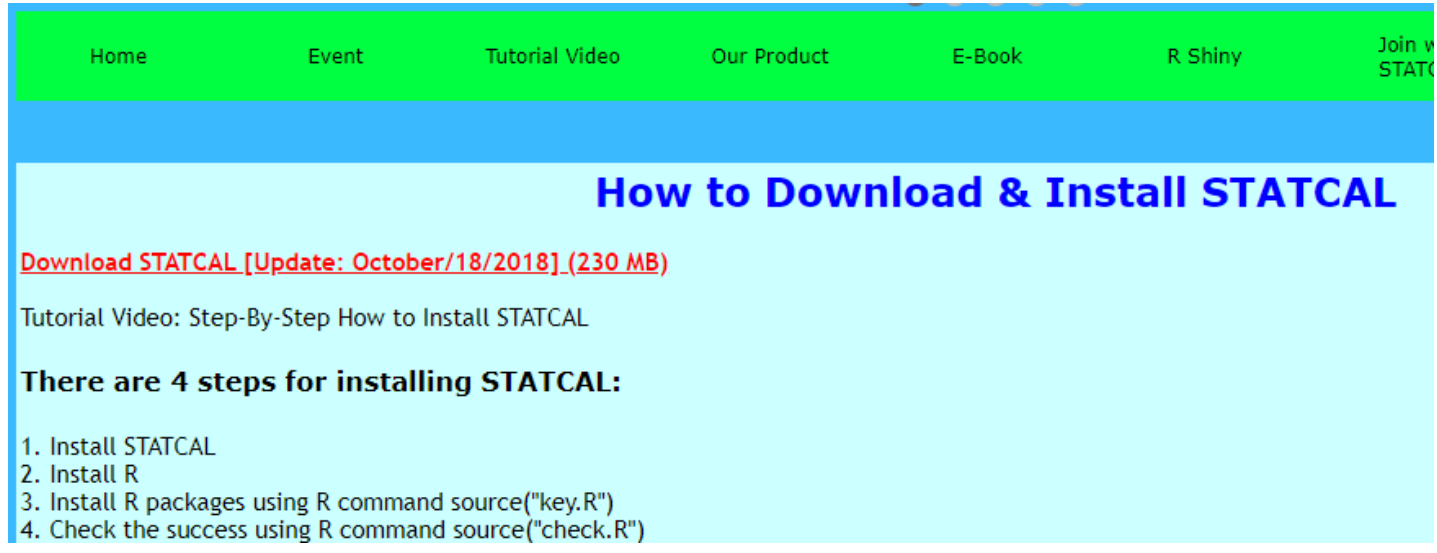

\section{“Tinggalkan Jejakmu dalam Suatu Karya yang Bermanfaat"}




\section{DAFTAR ISI}

1. Membuat Grafik Batang Rata-Rata dengan Menu Bar: Average-I

2. Membuat Grafik Batang Rata-Rata dengan Menu Bar: Average-II

3. Membuat Grafik Batang Rata-Rata dengan Menu Bar: Average-III

4. Membuat Grafik Batang Rata-Rata dengan Menu Bar: Average-IV

5. Membuat Grafik Batang Rata-Rata dengan Menu Bar: Average-V

6. Membuat Grafik Batang Frekuensi dengan Menu Bar: Frequency-I

7. Membuat Grafik Batang Frekuensi dengan Menu Bar: Frequency-II

8. Membuat Grafik Batang Frekuensi dengan Menu Bar: Other-I (Skala Likert)

9. Membuat Grafik Batang Frekuensi dengan Menu Bar: Other-III

10. Membuat Grafik Batang Rata-Rata dengan Menu Bar: Other-III

11. Membuat Grafik Batang Frekuensi dengan Menu Bar: Other-IV

12. Membuat Grafik Batang Rata-Rata dengan Menu Bar: Other-IV

13. Membuat Grafik Batang Frekuensi dengan Menu Bar: Other-V

14. Membuat Grafik Batang Rata-Rata dengan Menu Bar: Other-V

15. Membuat Grafik Garis Rata-Rata dengan Menu Line: Average-I

16. Membuat Grafik Garis Rata-Rata dengan Menu Line: Average-II

17. Membuat Grafik Garis Rata-Rata dengan Menu Line: Average-III

18. Membuat Grafik Garis Frekuensi dengan Menu Line: Frequency-I

19. Membuat Grafik Garis Frekuensi dengan Menu Line: Other-I

20. Membuat Grafik Garis Rata-Rata dengan Menu Line: Other-I

21. Membuat Grafik Garis Frekuensi dengan Menu Line: Other-II

22. Membuat Grafik Garis Rata-Rata dengan Menu Line: Other-II

23. Membuat Grafik Garis dengan Menu Line: Other-III

24. Membuat Grafik Lingkaran Frekuensi dengan Menu Circle: Frequency-I

25. Membuat Grafik Lingkaran Frekuensi dengan Menu Circle: Frequency-II

26. Membuat Grafik Sebaran Data dengan Menu Boxplot-I

27. Membuat Grafik Sebaran Data dengan Menu Boxplot-II

28. Membuat Grafik Korelasi dengan Menu Correlation-I

29. Membuat Grafik Korelasi dengan Menu Correlation-II

30. Membuat Grafik Sebaran Data dengan Menu Scatter Plot-I

31. Membuat Grafik Sebaran Data dengan Menu Scatter Plot-II

32. Membuat Grafik Sebaran Data dengan Menu Scatter Plot-III

33. Membuat Grafik Sebaran Data dengan Menu Scatter Plot-IV

34. Membuat Grafik Sebaran Data dengan Menu Scatter Plot-V

35. Membuat Grafik Time Series dengan Menu Time Series-I

36. Membuat Grafik Time Series dengan Menu Time Series-II 


\section{Mengolah Data dengan}

Program Aplikasi Statistika

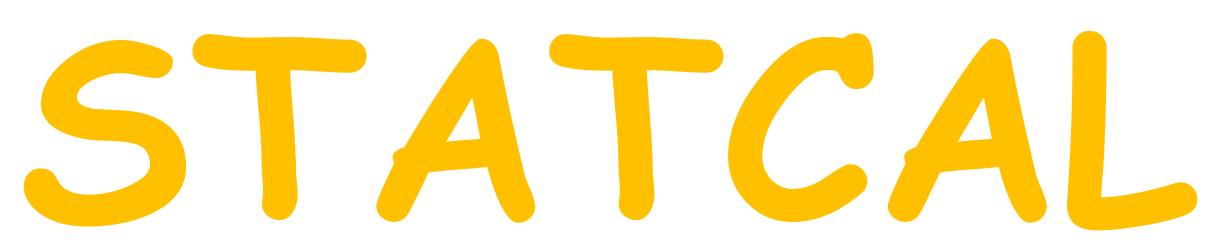

Membuat Grafik Batang Rata-Rata dengan Menu Bar: Average-I

Oleh Prana Ugiana Gio

Founder \& CEO STATCAL

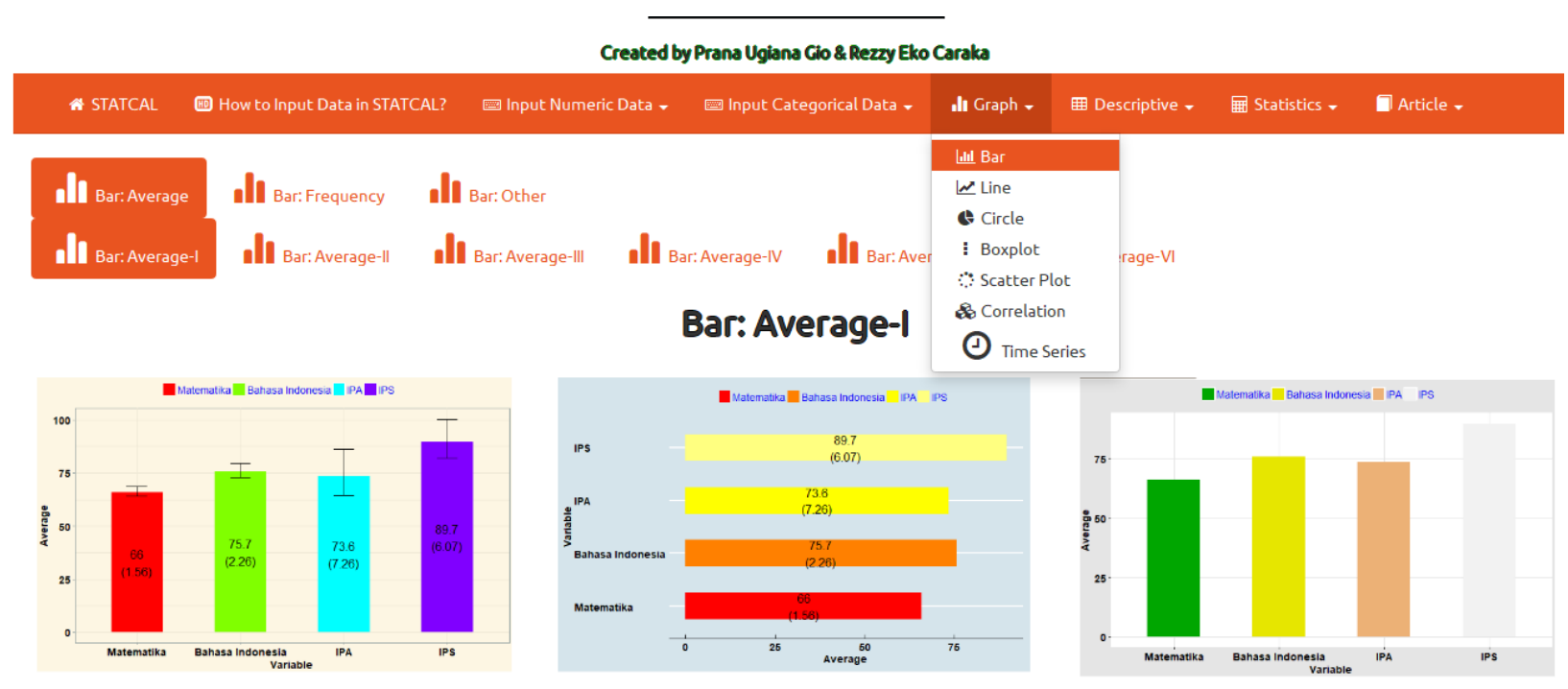


Misalkan diberikan data nilai ujian matematika, bahasa Indonesia, IPA dan IPS dari 10 siswa (Tabel 1.1).

Tabel 1.1 Data Nilai Ujian Matematika, Bahasa Indonesia,
IPA dan IPS dari 10 Siswa (Data Fiktif)

\begin{tabular}{|c|c|c|c|c|}
\hline Nama & Matematika & Bahasa Indonesia & IPA & IPS \\
\hline Andi & 67 & 71 & 66 & 89 \\
\hline Ugi & 66 & 77 & 67 & 88 \\
\hline Edi & 65 & 75 & 67 & 87 \\
\hline Rani & 67 & 78 & 88 & 89 \\
\hline Rini & 65 & 76 & 76 & 98 \\
\hline Dina & 64 & 77 & 77 & 94 \\
\hline Fitri & 69 & 75 & 76 & 78 \\
\hline Budi & 64 & 79 & 65 & 99 \\
\hline Santoso & 66 & 74 & 78 & 87 \\
\hline Dono & 67 & 75 & 76 & 88 \\
\hline
\end{tabular}

Berdasarkan data pada Tabel 1.1, diketahui siswa yang bernama Ugi, memperoleh nilai matematika 67, nilai bahasa Indonesia 71, nilai IPA 66 dan nilai IPS 89. Dari data pada Tabel 1.1, disajikan grafik batang rata-rata seperti pada Gambar 1.1.

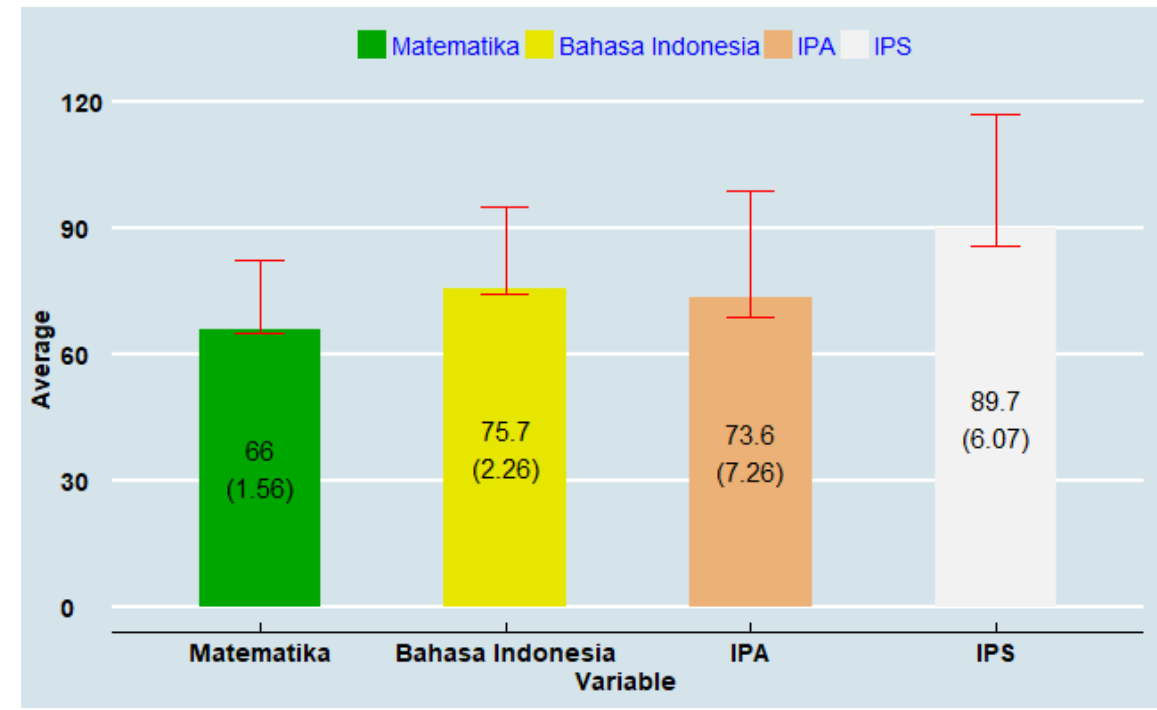

Gambar 1.1 Grafik Batang Rata-Rata 
Berdasarkan grafik batang rata-rata pada Gambar 1.1, diketahui:

$\Rightarrow$ Rata-rata nilai matematika adalah 66, dengan standar deviasi 1,56.

$\Rightarrow$ Rata-rata nilai bahasa Indonesia adalah 75,7, dengan standar deviasi 2,26, dan seterusnya.

Untuk membuat grafik batang rata-rata pada Gambar 1.1, kita akan menggunakan menu Bar: Average-I (Gambar 1.2).

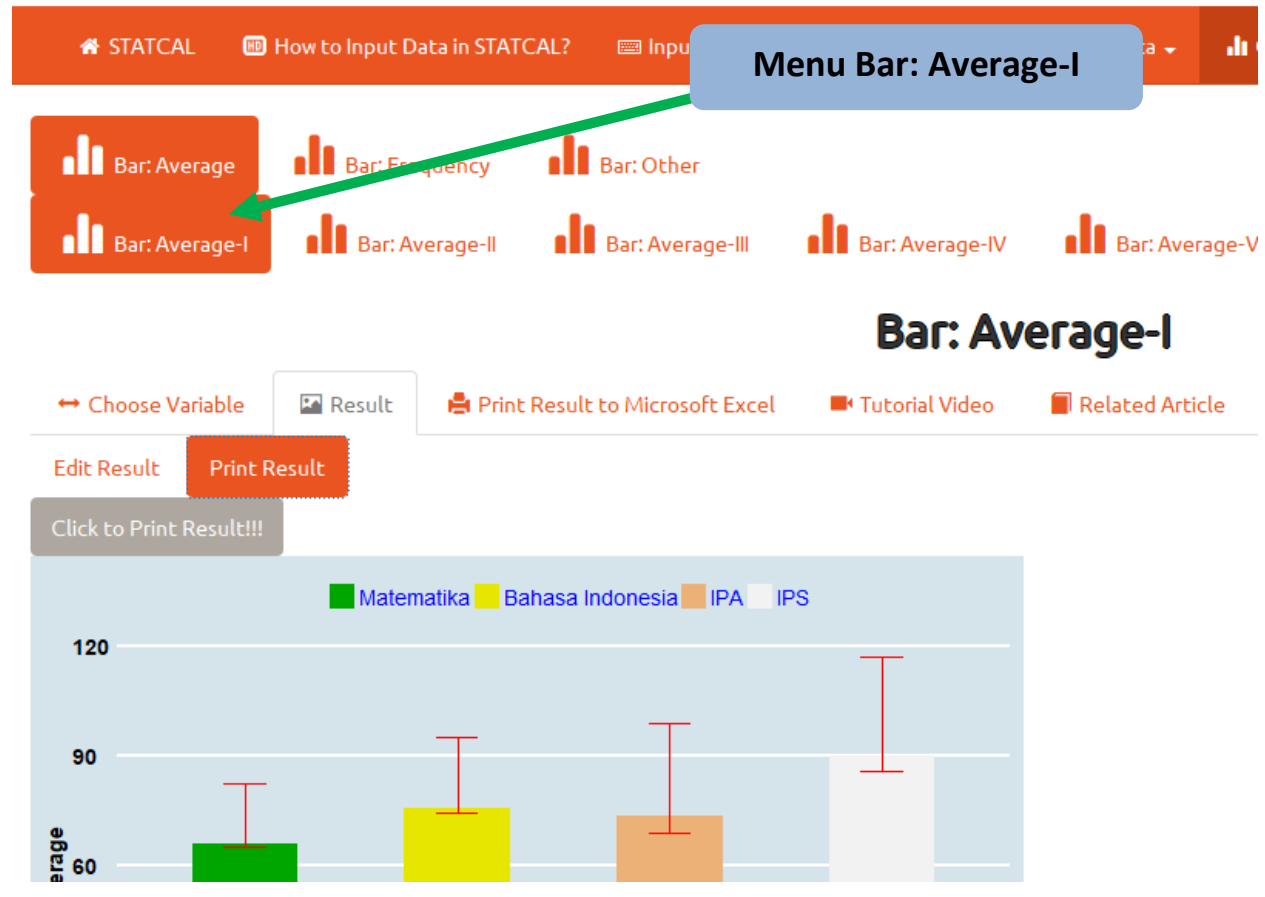

Gambar 1.2 Menu Bar: Average-I

Langkah pertama adalah input data pada Tabel 1.1 ke dalam STATCAL seperti pada Gambar 1.3. Perhatikan bahwa data diinput pada bagian Input Numeric Data. Selanjutnya kita akan mengakses menu Bar: Average-I dengan memilih Graph $=>$ Bar $=>$ Bar: Average $=>$ Bar: Average-I (Gambar 1.4). 


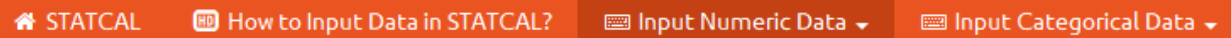

\section{㖥 Input Numeric Data}

\section{Numeric Data}

\begin{tabular}{l} 
Nanne of Variable \\
Matematika \\
Bahasa Indonesia \\
IPA \\
IPS \\
\hline
\end{tabular}

\section{Sett Nuniber of Coluño}

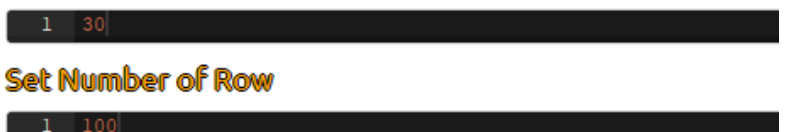

\begin{tabular}{|c|c|c|c|c|c|c|c|c|}
\hline \multicolumn{1}{|c|}{100} & \multicolumn{1}{|c|}{ V3 } & V4 & V5 & V6 & V7 & V8 \\
\hline 1 & 67.00 & 71.00 & 66.00 & 89.00 & & & & \\
\hline 2 & 66.00 & 77.00 & 67.00 & 88.00 & & & \\
\hline 3 & 65.00 & 75.00 & 67.00 & 87.00 & & & \\
\hline 4 & 67.00 & 78.00 & 88.00 & 89.00 & & & \\
\hline 5 & 65.00 & 76.00 & 76.00 & 98.00 & & & \\
\hline 6 & 64.00 & 77.00 & 77.00 & 94.00 & & & \\
\hline 7 & 69.00 & 75.00 & 76.00 & 78.00 & & & \\
\hline 8 & 64.00 & 79.00 & 65.00 & 99.00 & & & \\
\hline 9 & 66.00 & 74.00 & 78.00 & 87.00 & & & \\
\hline 10 & 67.00 & 75.00 & 76.00 & 88.00 & & & \\
\hline 11 & & & & & & & \\
\hline & $\mathbf{0}$ & $\mathbf{0}$ & $\mathbf{N}$ & & & \\
\hline
\end{tabular}

\footnotetext{
Matematika Bahasa Indonesia IPA IPS $\begin{array}{llll}67 & 71 & 66 & 89\end{array}$

$\begin{array}{llll}66 & 77 & 67 & 88\end{array}$

$\begin{array}{llll}65 & 75 & 67 & 87\end{array}$

$\begin{array}{llll}67 & 78 & 88 & 89\end{array}$

$\begin{array}{llll}65 & 76 \quad 76 & 98\end{array}$

$\begin{array}{llll}64 & 77 & 77 & 94\end{array}$

$\begin{array}{llll}69 & 75 & 76 & 78\end{array}$

$\begin{array}{llll}64 & 79 & 65 & 99\end{array}$

$\begin{array}{llll}66 & 74 & 78 & 87\end{array}$

$\begin{array}{llll}67 & 75 & 76 & 88\end{array}$

Number of $\mathrm{NA}$ in Matematika $=0$

Number of NA in Bahasa Indonesia $=0$

Number of $\mathrm{NA}$ in $\mathrm{IPA}=0$

Number of $\mathrm{NA}$ in IPS $=0$
}

Gambar 1.3 Input Data Numerik pada Bagian Input Numeric Data 


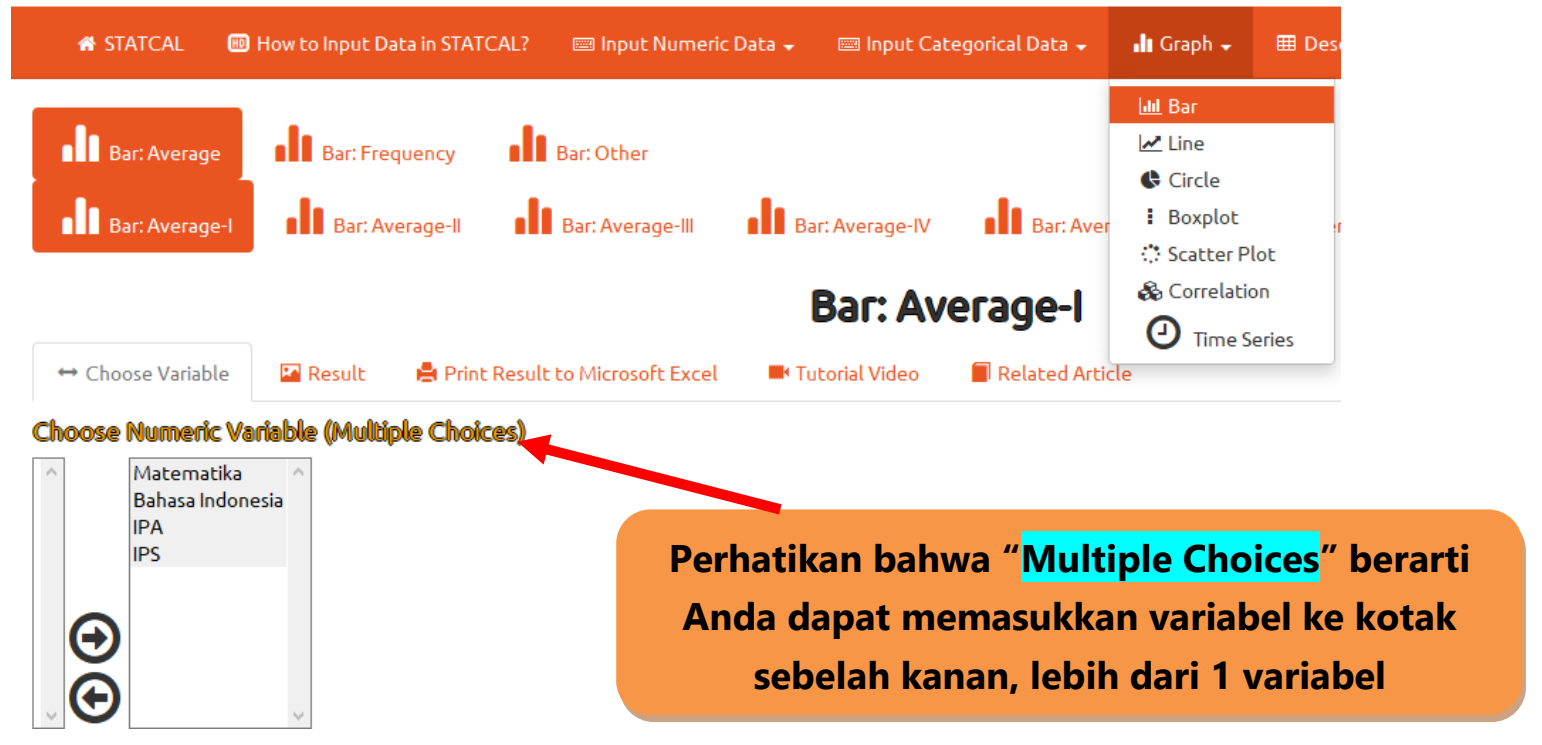

Gambar 1.4 Menu Bar: Average-I

Pada Gambar 1.4, bagian Choose Numeric Variable (Multiple Choices), pindahkan seluruh variabel ke kotak sebelah kanan. Gambar 1.5 merupakan keterangan beberapa menu pada Bar:

Average-I.

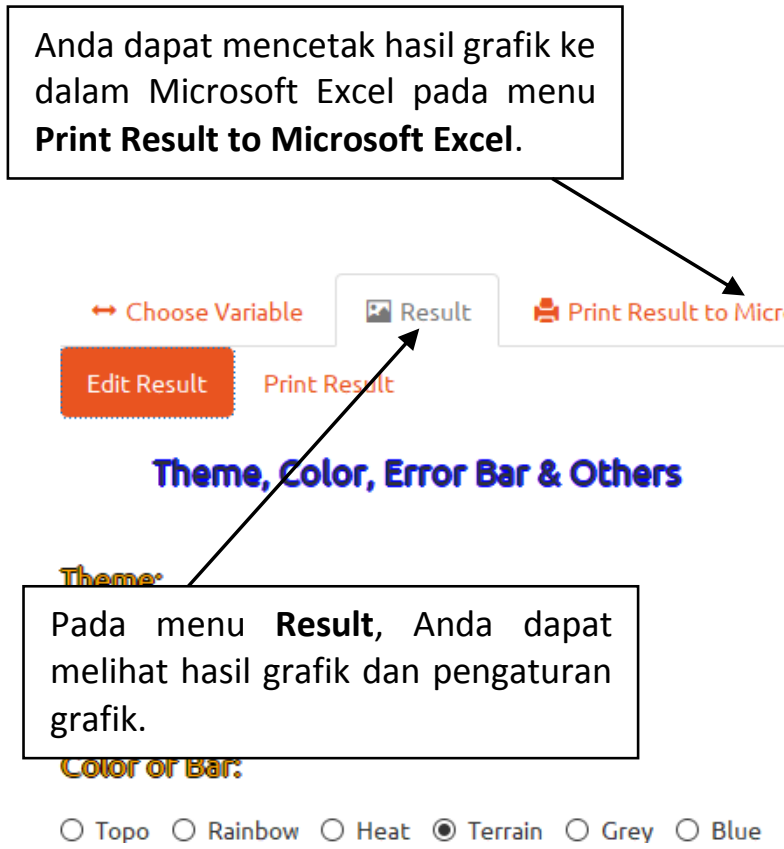

Tutorial video terkait membuat grafik Bar: Average-I dapat dilihat pada bagian Tutorial Video. Untuk memutar video tersebut, pastikan terkoneksi internet!!!

Gambar 1.5 Keterangan Beberapa Menu pada Bar: Average-I 
Gambar 1.6 disajikan grafik batang rata-rata.

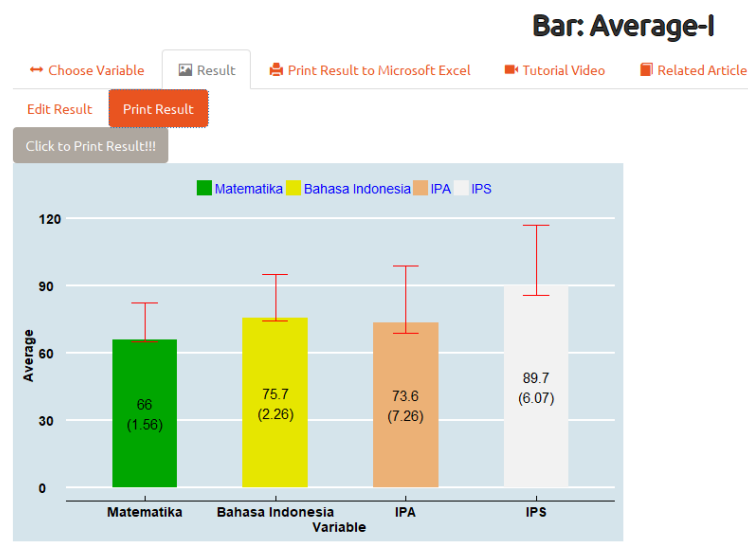

\section{Gambar 1.6 Grafik Batang Rata-Rata}

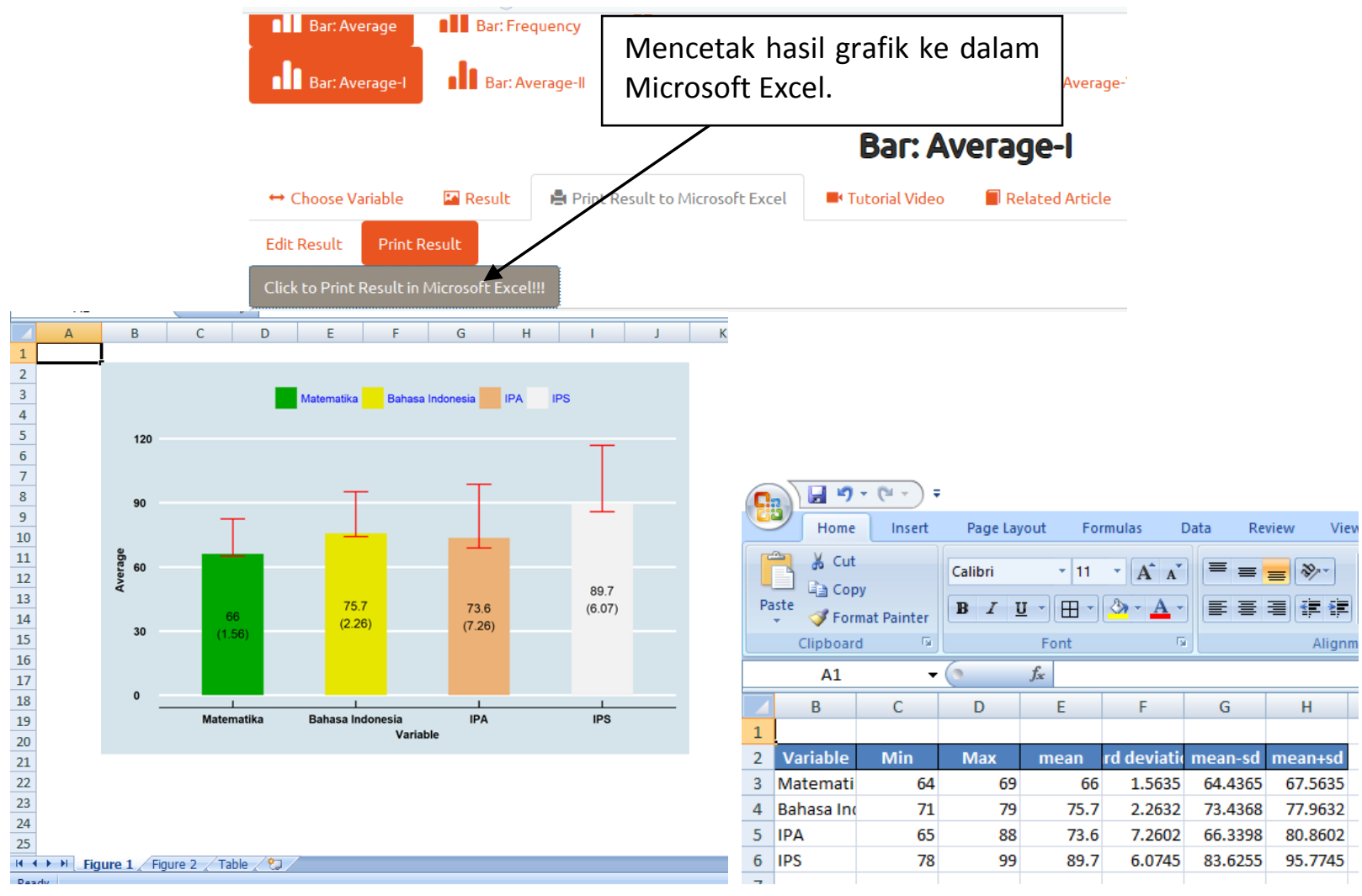

\section{Gambar 1.7 Hasil Grafik Dicetak ke Microsoft Excel}

Gambar 1.7 diperlihatkan hasil grafik dicetak ke dalam Microsoft Excel. 


\section{Mengolah Data dengan}

Program Aplikasi Statistika

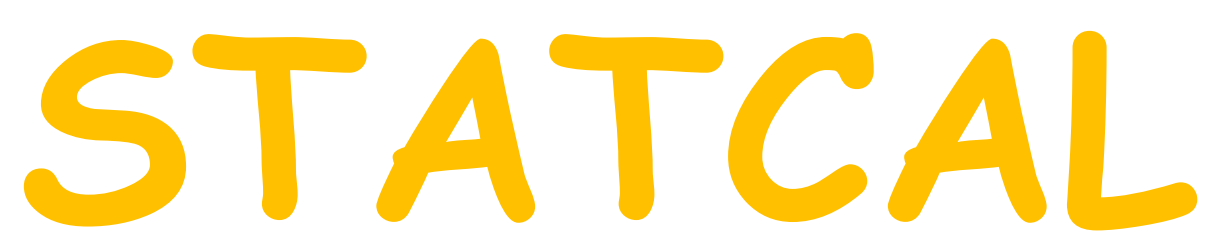

Membuat Grafik Batang Rata-Rata dengan Menu

Bar: Average-II

Oleh Prana Ugiana Gio

Founder \& CEO STATCAL

Created by Prana Ugiana Gio \& Rezzy Eko Caraka

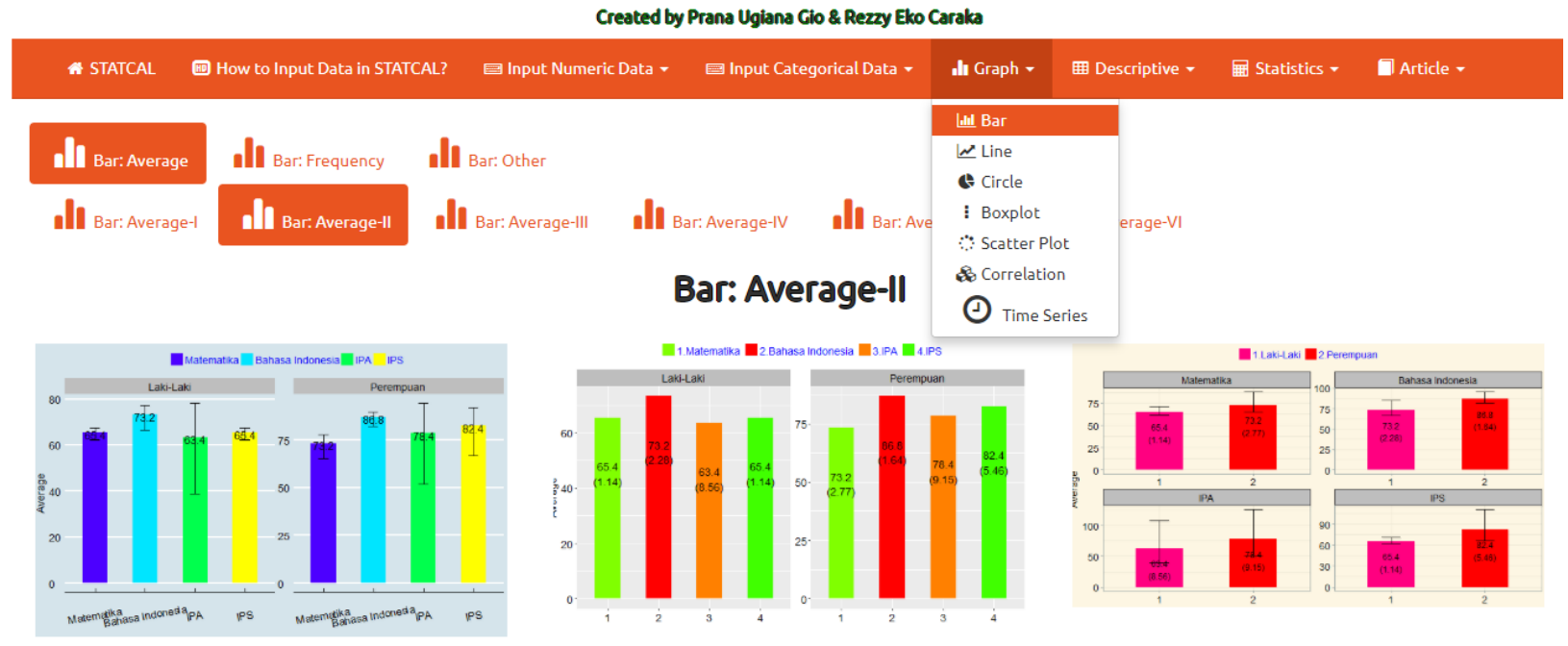


Misalkan diberikan data nilai ujian matematika, bahasa Indonesia, IPA dan IPS, berdasarkan jenis kelamin, dari 10 siswa (Tabel 1.1).

Tabel 1.1 Data Nilai Ujian Matematika, Bahasa Indonesia, IPA dan IPS berdasarkan Jenis Kelamin dari 10 Siswa (Data Fiktif)

\begin{tabular}{|c|c|c|c|c|c|}
\hline Nama & Jenis Kelamin & Matematika & Bahasa Indonesia & IPA & IPS \\
\hline Ugi & 1 & 65 & 71 & 65 & 65 \\
\hline Egi & 1 & 66 & 72 & 67 & 66 \\
\hline Andi & 1 & 67 & 77 & 54 & 67 \\
\hline Anto & 1 & 65 & 73 & 56 & 64 \\
\hline Amar & 1 & 64 & 73 & 75 & 65 \\
\hline Rini & 2 & 71 & 85 & 76 & 85 \\
\hline Rina & 2 & 70 & 88 & 77 & 87 \\
\hline Riri & 2 & 74 & 86 & 87 & 77 \\
\hline Dira & 2 & 77 & 89 & 87 & 87 \\
\hline Fitri & 2 & 74 & 86 & 65 & 76 \\
\hline
\end{tabular}

\begin{tabular}{|c|c|}
\hline \multirow{2}{*}{ Angka } & Label \\
\cline { 2 - 2 } & Jenis Kelamin \\
\hline 1 & Laki-laki \\
\hline 2 & Perempuan \\
\hline
\end{tabular}

Berdasarkan data pada Tabel 1.1, diketahui siswa yang bernama Ugi, dengan jenis kelamin lakilaki, memperoleh nilai matematika 65, nilai bahasa Indonesia 71, nilai IPA 65 dan nilai IPS 65.

Dari data pada Tabel 1.1, disajikan grafik batang rata-rata seperti pada Gambar 1.1 dan Gambar 1.2. 


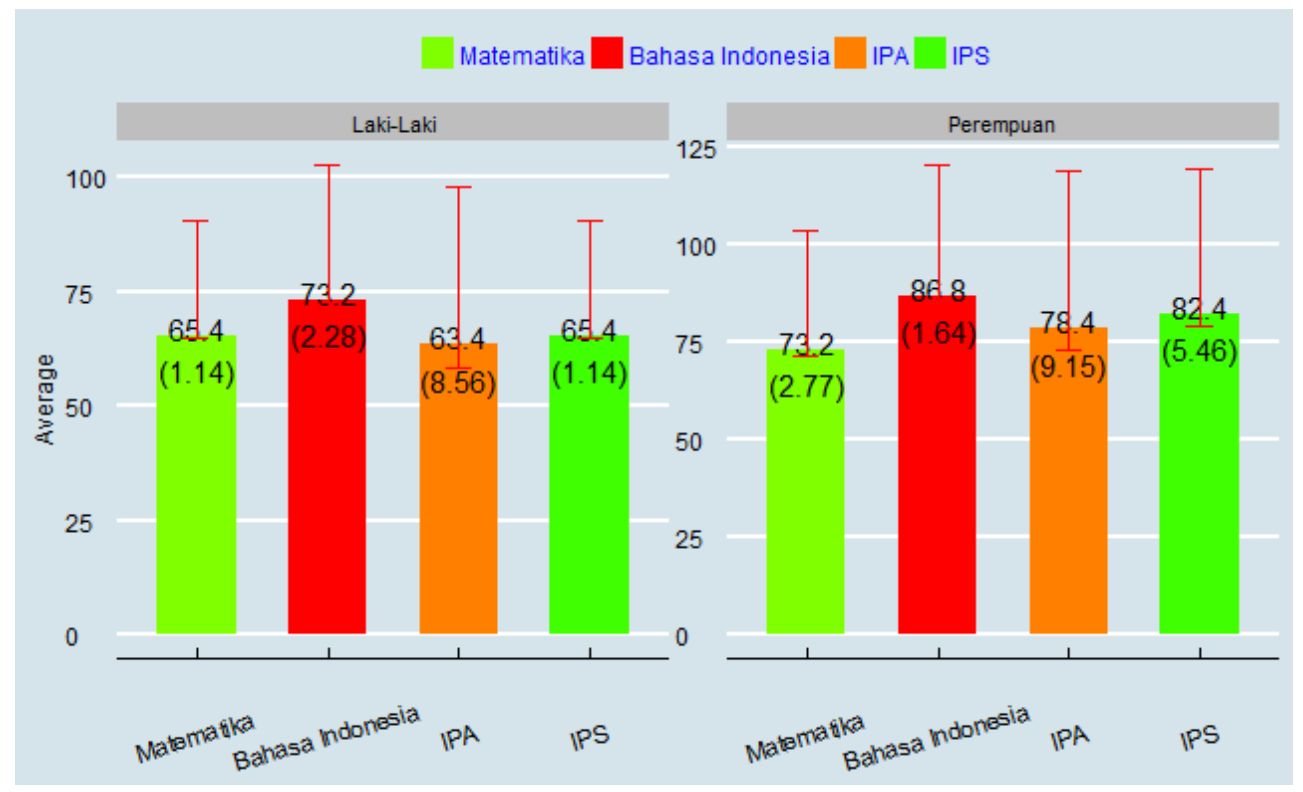

Gambar 1.1 Grafik Batang Rata-Rata

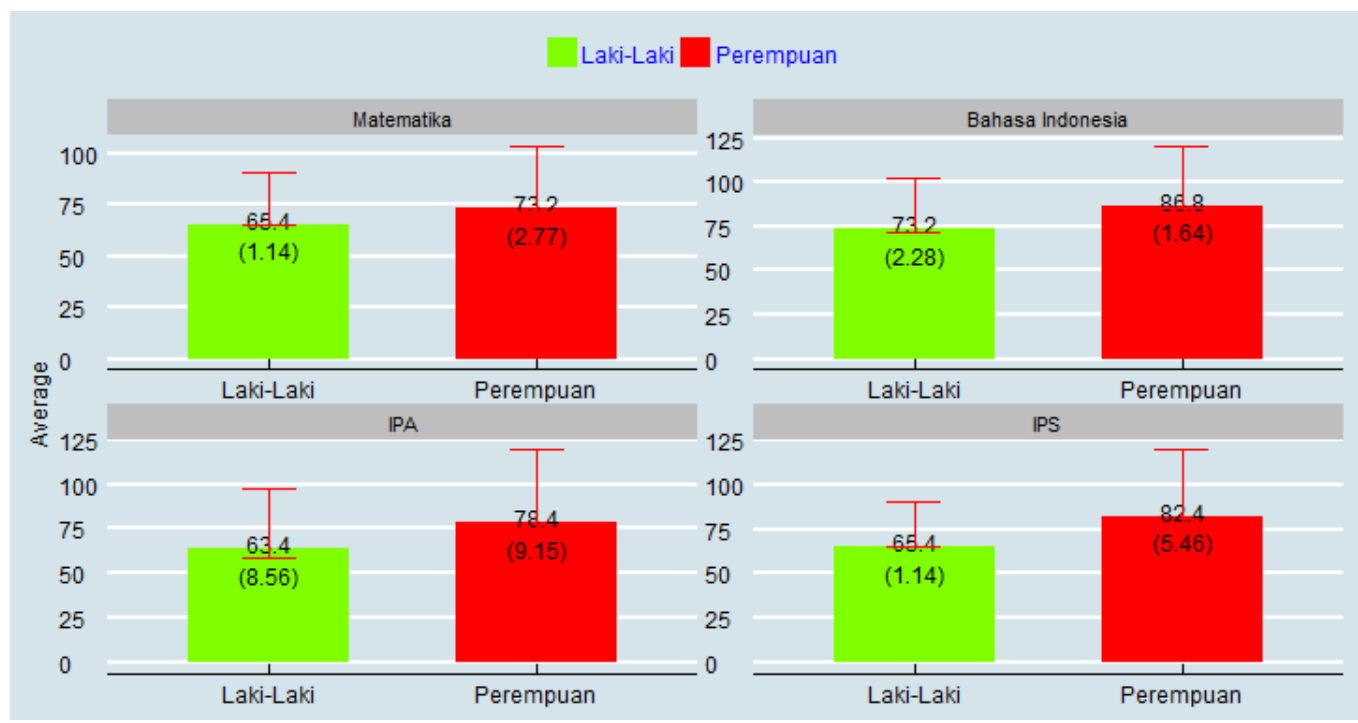

Gambar 1.2 Grafik Batang Rata-Rata

Berdasarkan grafik batang rata-rata pada Gambar 1.1 dan Gambar 1.2, diketahui:

$\Rightarrow$ Rata-rata nilai matematika laki-laki adalah 65,4 , dengan standar deviasi 1,14 . Sementara rata-rata nilai matematika perempuan adalah 73,2, dengan standar deviasi 2,77. 
$\Rightarrow$ Rata-rata nilai bahasa indonesia laki-laki adalah 73,2, dengan standar deviasi 2,28. Sementara rata-rata nilai bahasa indonesia perempuan adalah 86,8, dengan standar deviasi 1,64.

Untuk membuat grafik batang rata-rata pada Gambar 1.1 dan Gambar 1.2, kita akan menggunakan menu Bar: Average-II (Gambar 1.3).

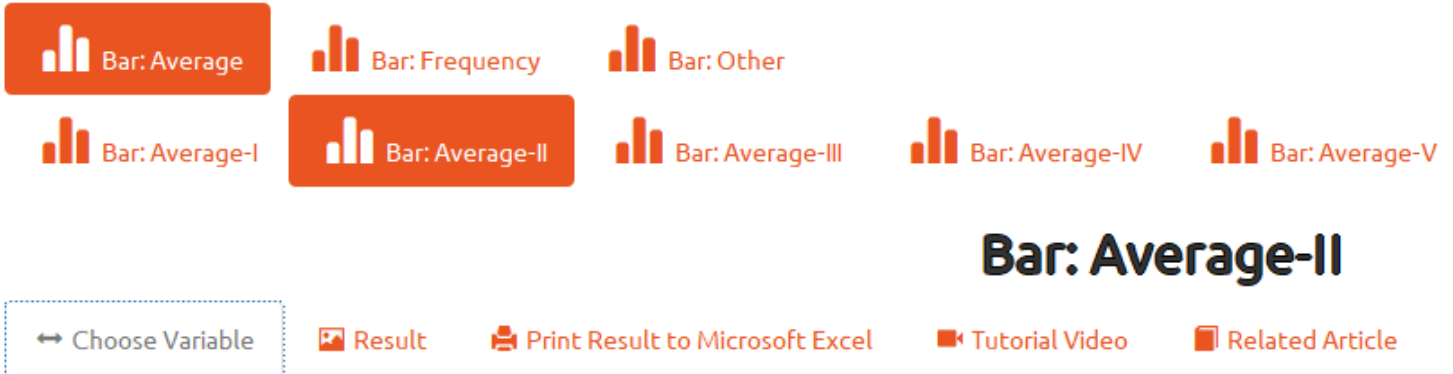

\section{Gambar 1.3 Menu Bar: Average-II}

Langkah pertama adalah input data pada Tabel 1.1 ke dalam STATCAL seperti pada Gambar 1.4 (input data numerik) dan Gambar 1.5 (input data kategori). Selanjutnya kita akan mengakses menu Bar: Average-II dengan memilih Graph => Bar => Bar: Average => Bar: Average-II (Gambar 1.6). 


\section{A STATCAL 四 How to Input Data in STATCAL? 四 Input Numeric Data v 回 Input Categorical Data v}

\section{Numeric Data}

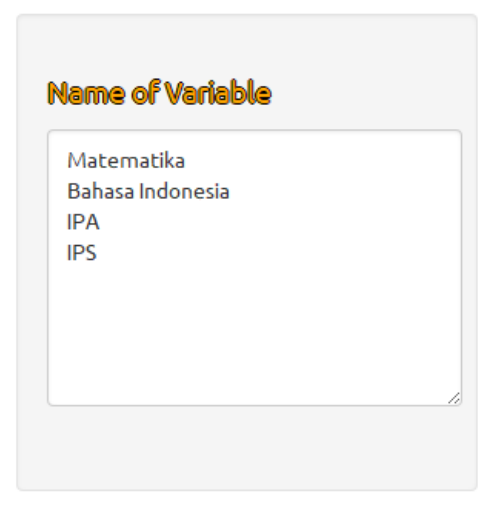

\section{Selt Nunober of Colunono}

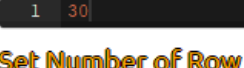

\section{Selt Nundoer of Rom}

\begin{tabular}{|c|c|c|c|c|c|c|c|c|}
\hline 1 100 & & & & & & \\
\hline & V1 & V2 & V3 & V4 & V5 & V6 & V7 & V8 \\
\hline 1 & 65.00 & 71.00 & 65.00 & 65.00 & & & & \\
\hline 2 & 66.00 & 72.00 & 67.00 & 66.00 & & & & \\
\hline 3 & 67.00 & 77.00 & 54.00 & 67.00 & & & & \\
\hline 4 & 65.00 & 73.00 & 56.00 & 64.00 & & & & \\
\hline 5 & 64.00 & 73.00 & 75.00 & 65.00 & & & & \\
\hline 6 & 71.00 & 85.00 & 76.00 & 85.00 & & & & \\
\hline 7 & 70.00 & 88.00 & 77.00 & 87.00 & & & & \\
\hline 8 & 74.00 & 86.00 & 87.00 & 77.00 & & & & \\
\hline 9 & 77.00 & 89.00 & 87.00 & 87.00 & & & & \\
\hline 10 & 74.00 & 86.00 & 65.00 & 76.00 & & & & \\
\hline & & & & & & & \\
\hline
\end{tabular}

Gambar 1.4 Input Data Numerik

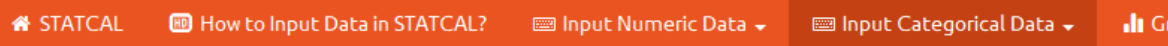

Input Categorical Data

\section{Categorical Data}

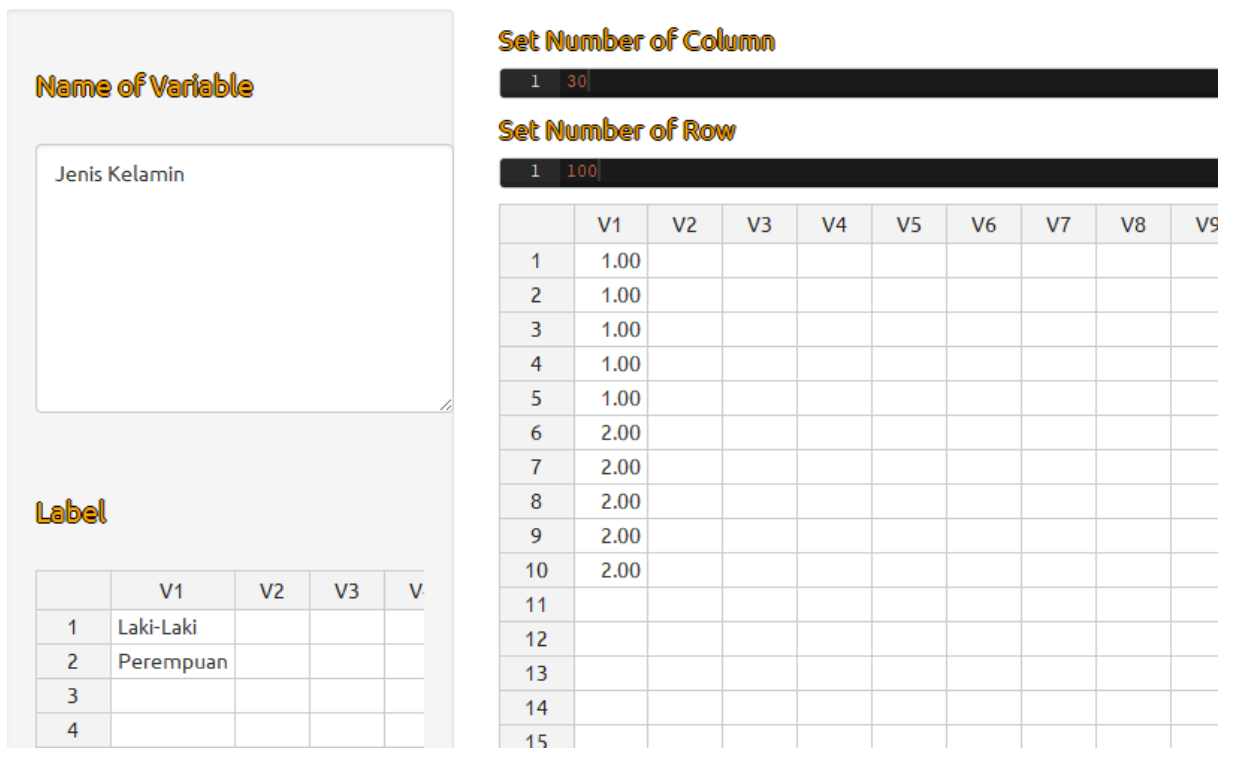

Gambar 1.5 Input Data Kategori 


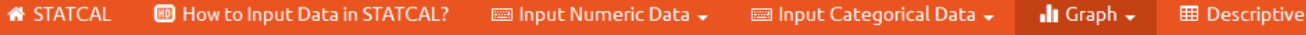

\begin{tabular}{|c|c|c|c|c|c|}
\hline Ill Bar:Average & Ill Bar: Frequency & dll Bar: Other & & & \\
\hline \multirow[t]{2}{*}{ Il Bar: Average-1 } & Il Bar: Average-\| & Ill Bar: Average-III & Il Bar: Average-IV & dll Bar: Average-v & |l| Bar: Average-VI \\
\hline & \multicolumn{5}{|c|}{ Bar: Average-Il } \\
\hline$\rightarrow$ Choose Variable & Result & sult to Microsofft Exce & - Tutorial Video & 1 Related Article & \\
\hline
\end{tabular}

Gambar 1.6 Menu Bar: Average-II

Pada Gambar 1.7:

$\Rightarrow$ Bagian Choose Numeric Variable (Multiple Choices), pindahkan seluruh variabel ke kotak sebelah kanan.

$\Rightarrow$ Bagian Choose Categorical Variable (Single Choice), pindahkan variabel jenis kelamin ke kotak sebelah kanan.

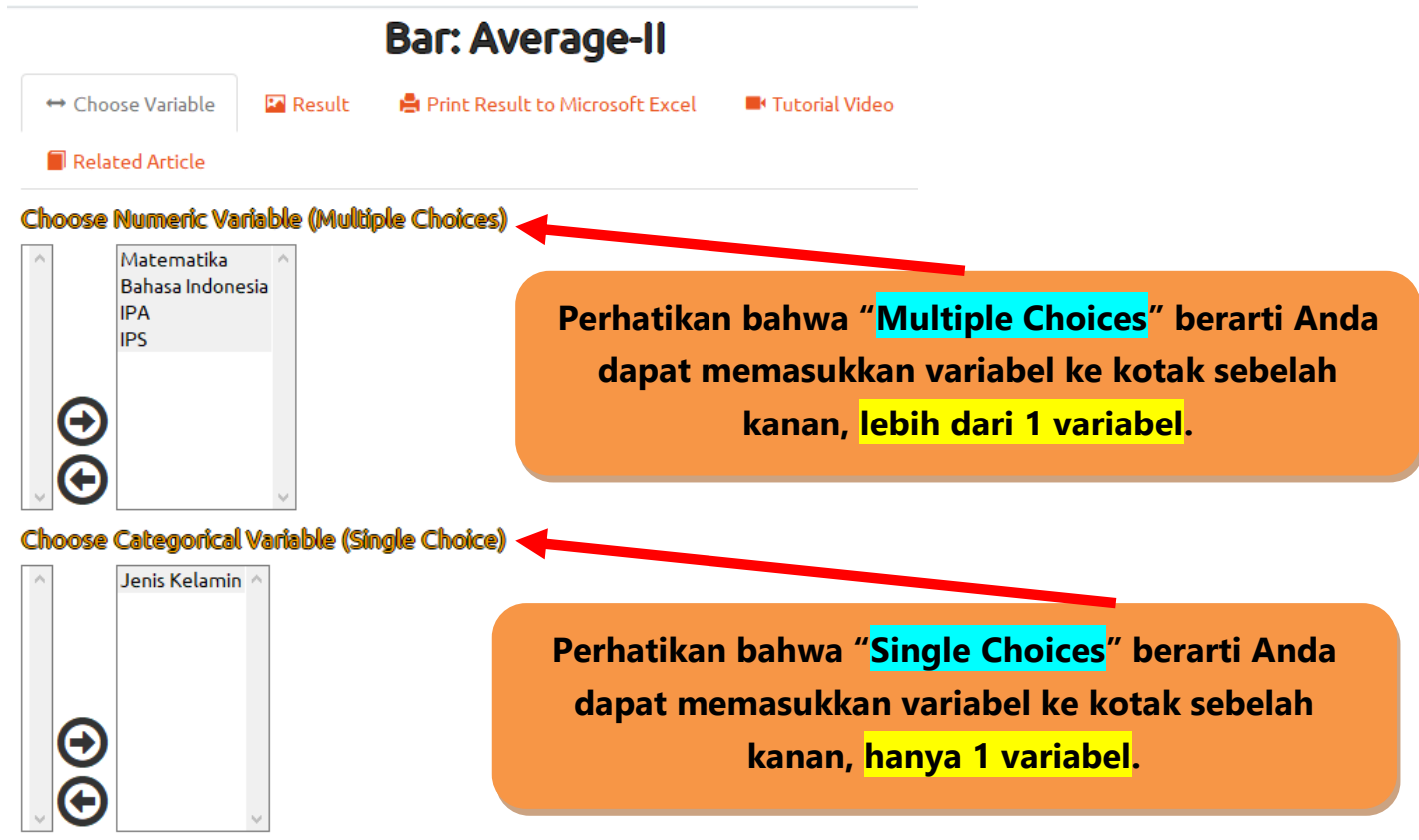

Gambar 1.7 Pemilihan Variabel 
Gambar 1.8 merupakan keterangan beberapa menu pada Bar: Average-II.

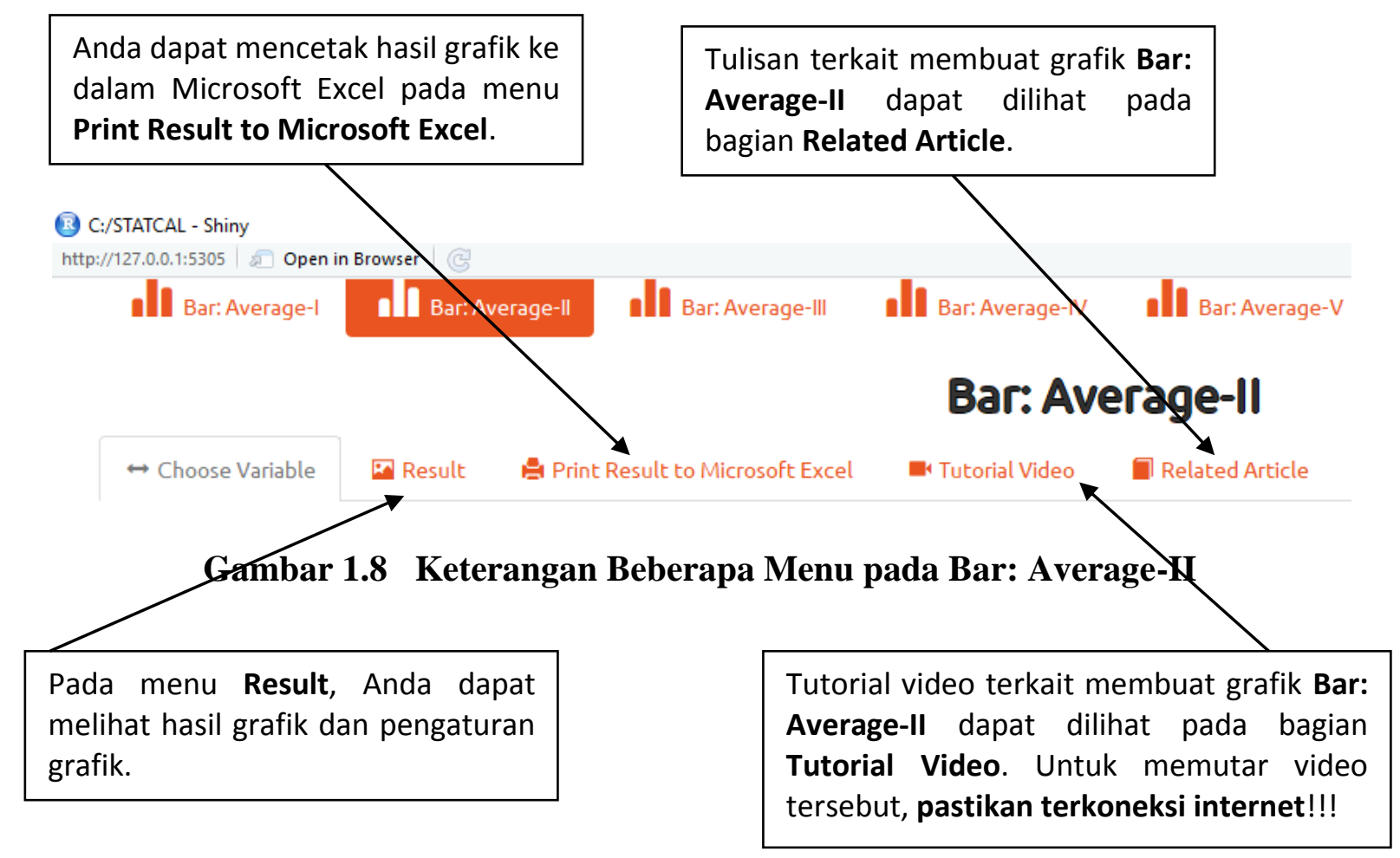

Gambar 1.9 disajikan grafik batang rata-rata.

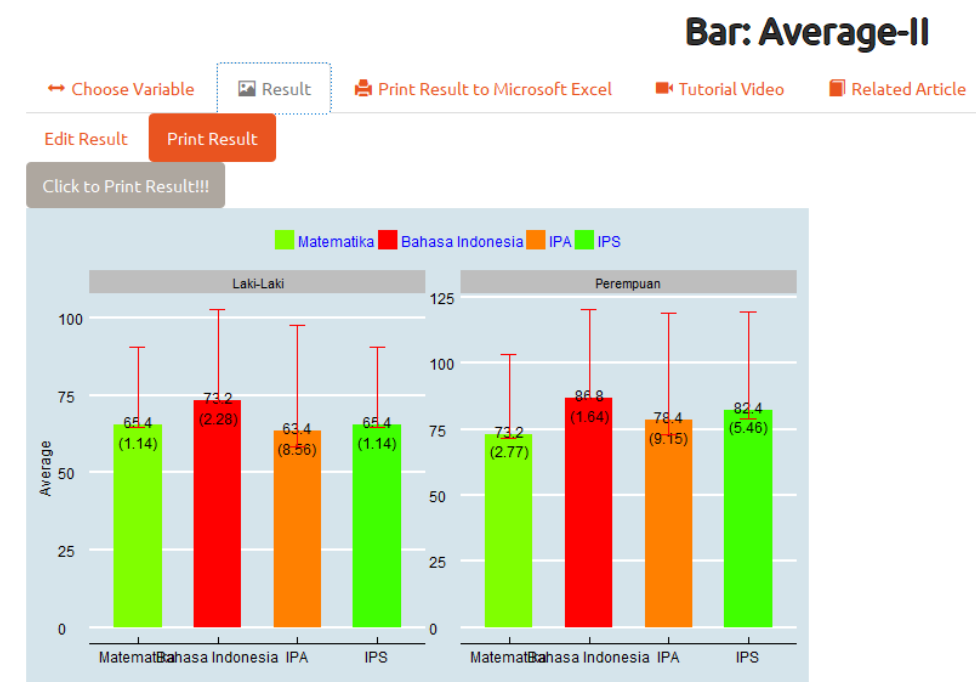

Gambar 1.9 Grafik Batang Rata-Rata 


\section{Mengolah Data dengan}

Program Aplikasi Statistika

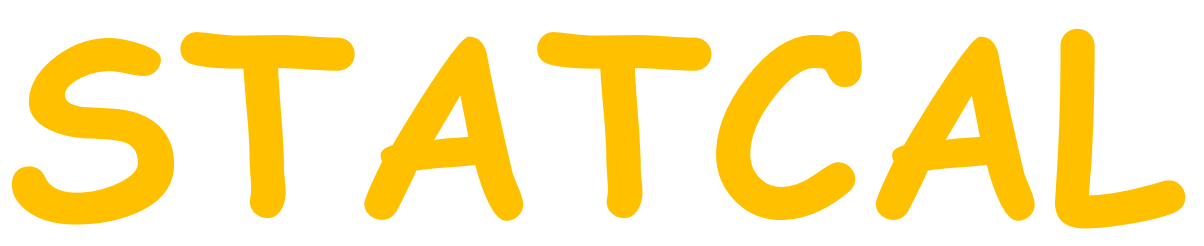

Membuat Grafik Batang Rata-Rata dengan Menu

Bar: Average-III

Oleh Prana Ugiana Gio

Founder \& CEO STATCAL

Created by Prana Ugiana Gio \& Rezzy Eko Caraka

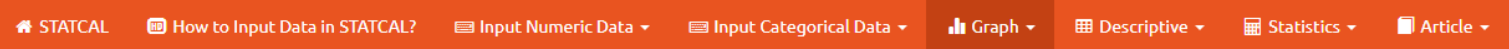

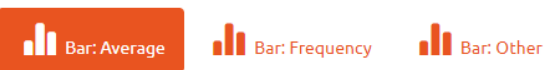

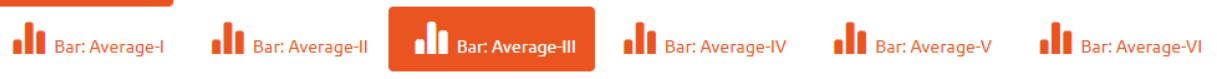

Bar: Average-III
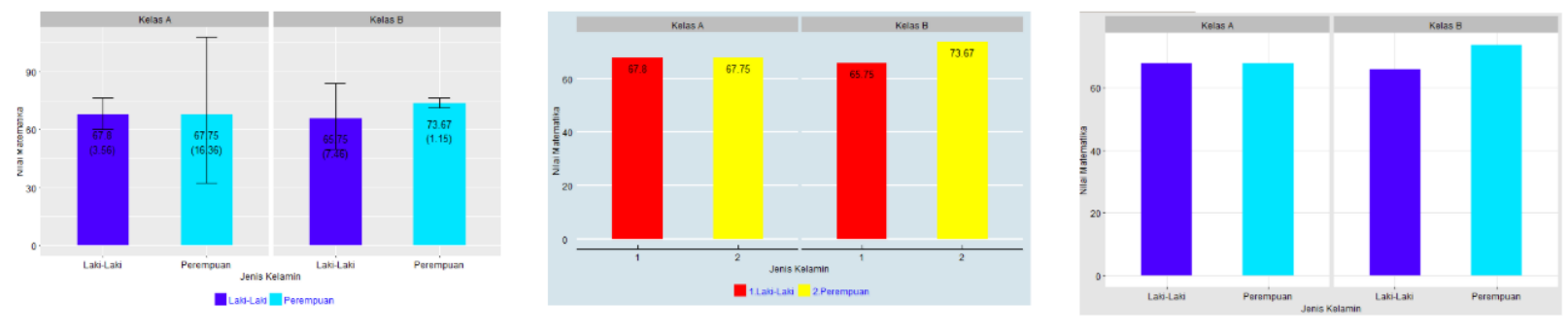
Misalkan diberikan data nilai ujian matematika berdasarkan jenis kelamin dan kelas (Tabel 1.1).

Tabel 1.1 Data Nilai Ujian Matematika berdasarkan Jenis Kelamin dan Kelas (Data Fiktif)

\begin{tabular}{|c|c|c|c|}
\hline Nama & Jenis Kelamin & Kelas & Nilai Matematika \\
\hline Andi & 1 & 1 & 65 \\
\hline Budi & 1 & 1 & 66 \\
\hline Ugi & 1 & 1 & 67 \\
\hline Egi & 1 & 1 & 74 \\
\hline Toni & 1 & 1 & 67 \\
\hline Tarno & 1 & 2 & 57 \\
\hline Geri & 1 & 2 & 64 \\
\hline Ganda & 1 & 2 & 75 \\
\hline Darmo & 1 & 2 & 67 \\
\hline Fitri & 2 & 1 & 83 \\
\hline Intan & 2 & 1 & 45 \\
\hline Sari & 2 & 1 & 75 \\
\hline Suci & 2 & 1 & 68 \\
\hline Rini & 2 & 2 & 73 \\
\hline Rina & 2 & 2 & 75 \\
\hline Fivi & 2 & 2 & 73 \\
\hline
\end{tabular}

\begin{tabular}{|c|c|c|}
\hline Angka & Jenis Kelamin & Kelas \\
\hline 1 & Laki-Laki & Kelas A \\
\hline 2 & Perempuan & Kelas B \\
\hline
\end{tabular}

Berdasarkan data pada Tabel 1.1, diketahui siswa yang bernama Ugi, dengan jenis kelamin lakilaki, kelas A, memperoleh nilai matematika 67. Dari data pada Tabel 1.1, disajikan grafik batang rata-rata seperti pada Gambar 1.1. 


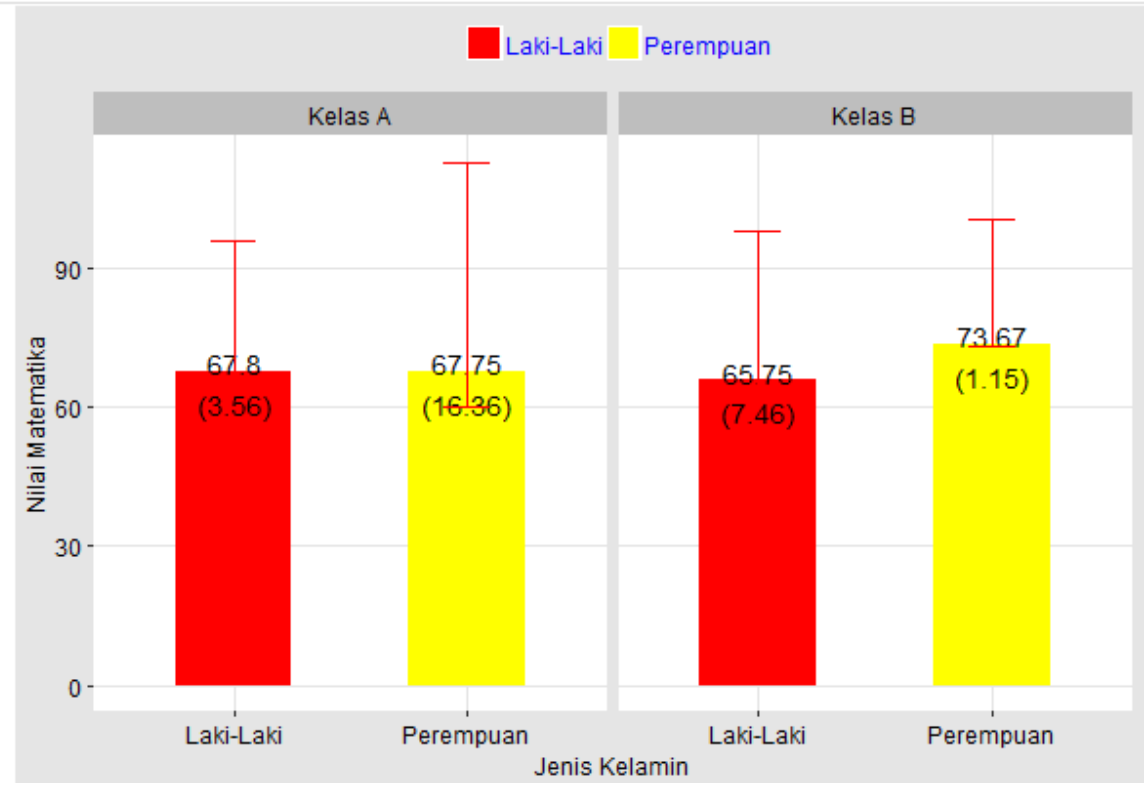

\section{Gambar 1.1 Grafik Batang Rata-Rata}

Berdasarkan grafik batang rata-rata pada Gambar 1.1, diketahui:

$\Rightarrow$ Rata-rata nilai matematika laki-laki kelas A adalah 67,8, dengan standar deviasi 3,56. Sementara rata-rata nilai matematika perempuan kelas A adalah 67,75 , dengan standar deviasi 16,36 .

$\Rightarrow$ Rata-rata nilai matematika laki-laki kelas B adalah 65,75, dengan standar deviasi 7,46. Sementara rata-rata nilai matematika perempuan kelas B adalah 73,67 , dengan standar deviasi 1,15 .

Untuk membuat grafik batang rata-rata pada Gambar 1.1, kita akan menggunakan menu Bar: Average-III (Gambar 1.2). 


$$
\begin{aligned}
& \text { all Bar: Average } \quad \text { all Bar: Frequency } \quad \text { ill Bar: Other }
\end{aligned}
$$

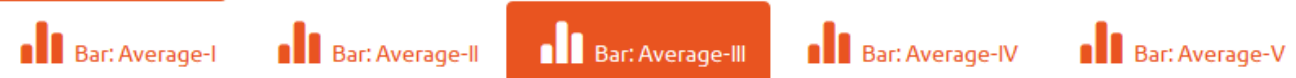

\section{Gambar 1.2 Menu Bar: Average-III}

Langkah pertama adalah input data pada Tabel 1.1 ke dalam STATCAL seperti pada Gambar 1.3 (input data numerik) dan Gambar 1.4 (input data kategori). Selanjutnya kita akan mengakses menu Bar: Average-III dengan memilih Graph $=>$ Bar $=>$ Bar: Average $=>$ Bar: AverageIII (Gambar 1.5).

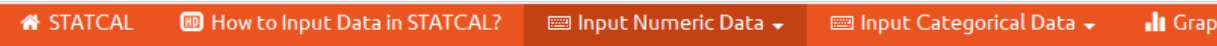 国 Input Numeric Data \\ Numeric Data}

\begin{tabular}{|c|c|c|c|c|c|c|c|c|c|c|}
\hline \multirow{19}{*}{$\begin{array}{l}\text { Nanne op Variable } \\
\text { Nilai Matematika }\end{array}$} & \multicolumn{10}{|c|}{ Sett Nunnber of Columan } \\
\hline & \multirow{2}{*}{\multicolumn{10}{|c|}{ Set Number of Row }} \\
\hline & & & & & & & & & & $1 \quad 100$ \\
\hline & 1 & $\begin{array}{c}\mathrm{V} 1 \\
\text { us.u }\end{array}$ & V2 & V3 & V4 & V5 & V6 & v7 & V8 & V9 \\
\hline & 2 & $66.0 \mathrm{c}$ & & & & & & & & \\
\hline & 3 & 67.00 & & & & & & & & \\
\hline & 4 & 74.00 & & & & & & & & \\
\hline & 5 & 67.0 & & & & & & & & \\
\hline & 6 & 57.00 & & & & & & & & \\
\hline & 7 & $64.0 \mathrm{c}$ & & & & & & & & \\
\hline & 8 & 75.00 & & & & & & & & \\
\hline & 9 & 67.00 & & & & & & & & \\
\hline & 10 & 83.00 & & & & & & & & \\
\hline & 11 & $45.0 \mathrm{c}$ & & & & & & & & \\
\hline & 12 & 75.00 & & & & & & & & \\
\hline & 13 & 68.00 & & & & & & & & \\
\hline & 14 & 73.00 & & & & & & & & \\
\hline & 15 & 75.00 & & & & & & & & \\
\hline & 16 & 73.00 & & & & & & & & \\
\hline
\end{tabular}

Gambar 1.3 Input Data Numerik 


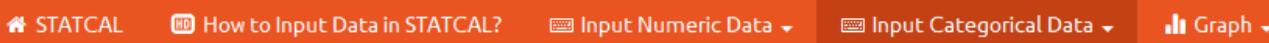

\section{国 Input Categorical Data}

\section{Categorical Data}

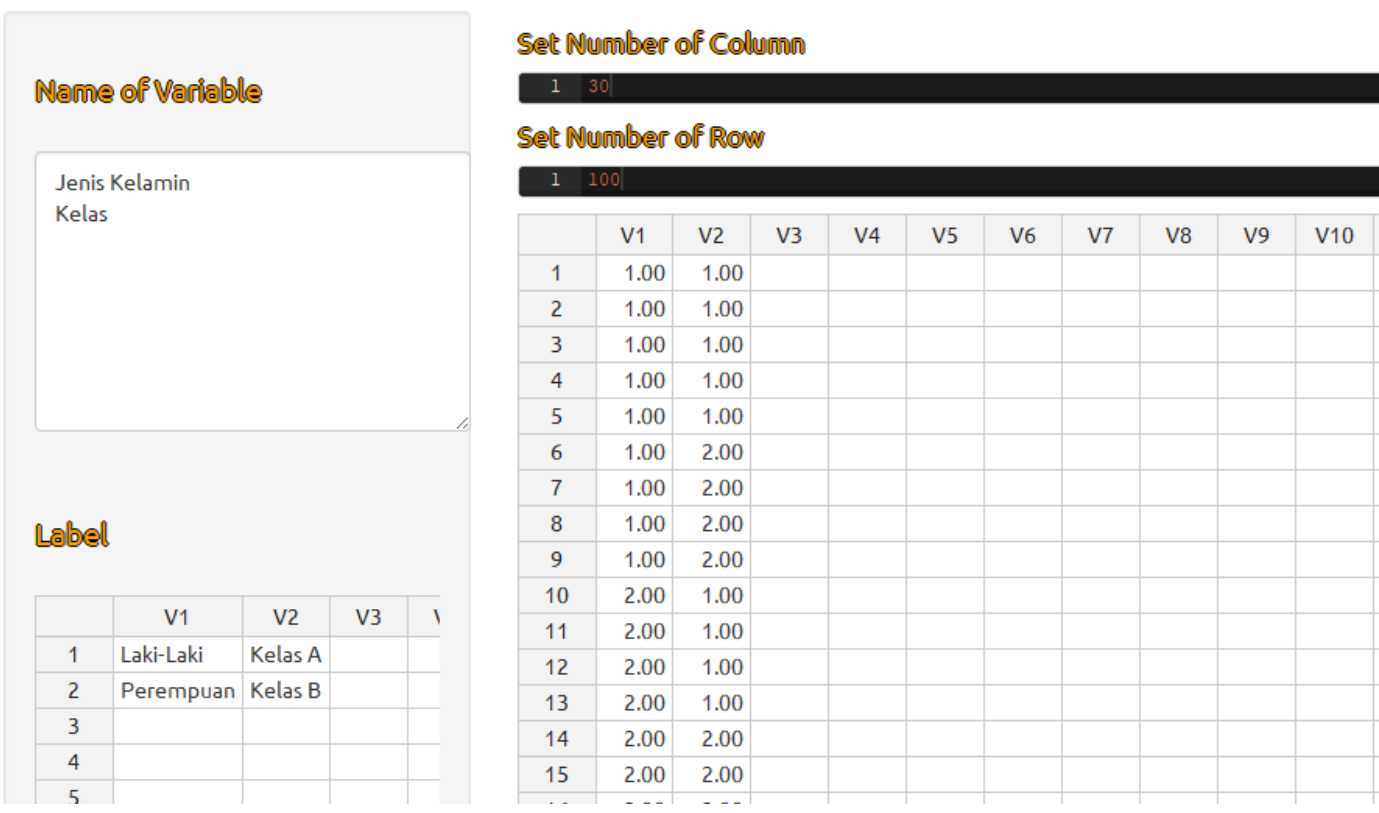

Gambar 1.4 Input Data Kategori

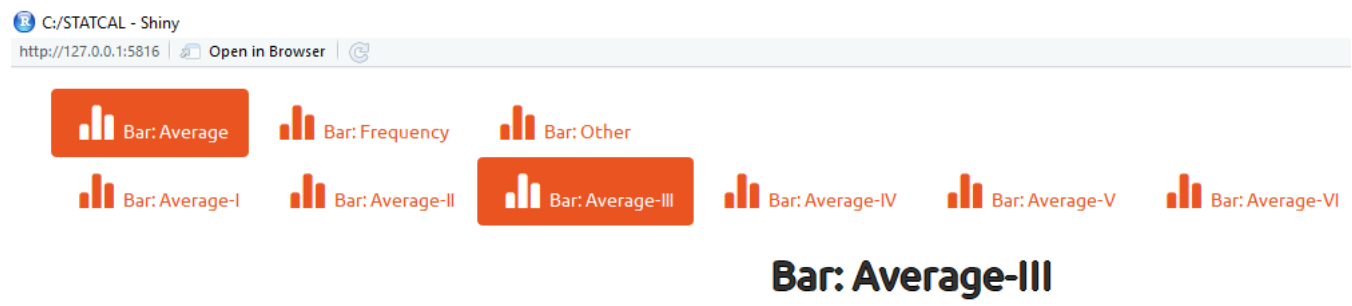

Gambar 1.5 Menu Bar: Average-III

Pada Gambar 1.6:

$\Rightarrow$ Bagian Choose Numeric Variable (Multiple Choices), pindahkan seluruh variabel ke kotak sebelah kanan.

$\Rightarrow$ Bagian Choose Categorical Variable (Single Choice), pindahkan variabel jenis kelamin ke kotak sebelah kanan. 


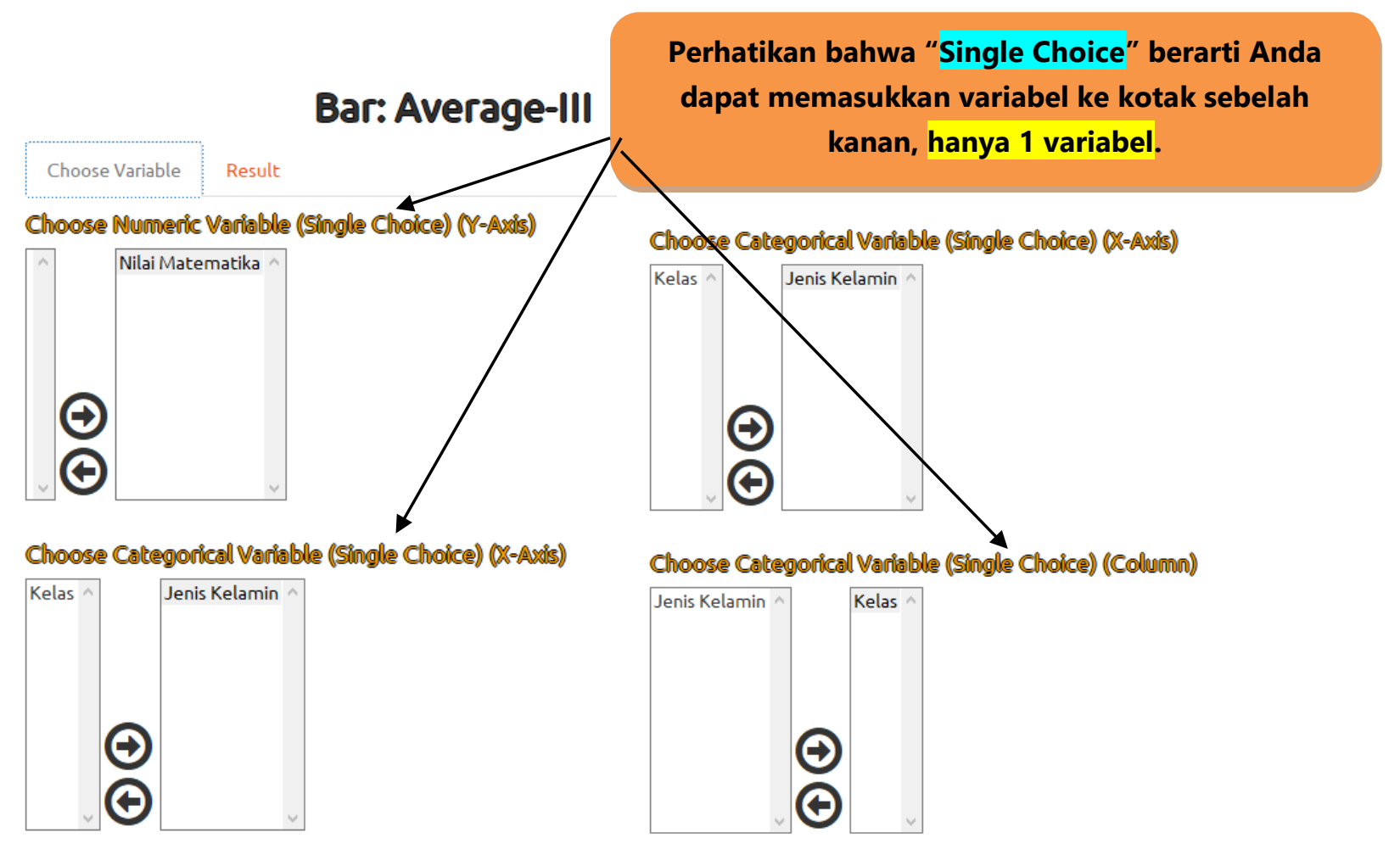

\section{Gambar 1.6 Pemilihan Variabel}

Gambar 1.7 merupakan keterangan beberapa menu pada Bar: Average-III.

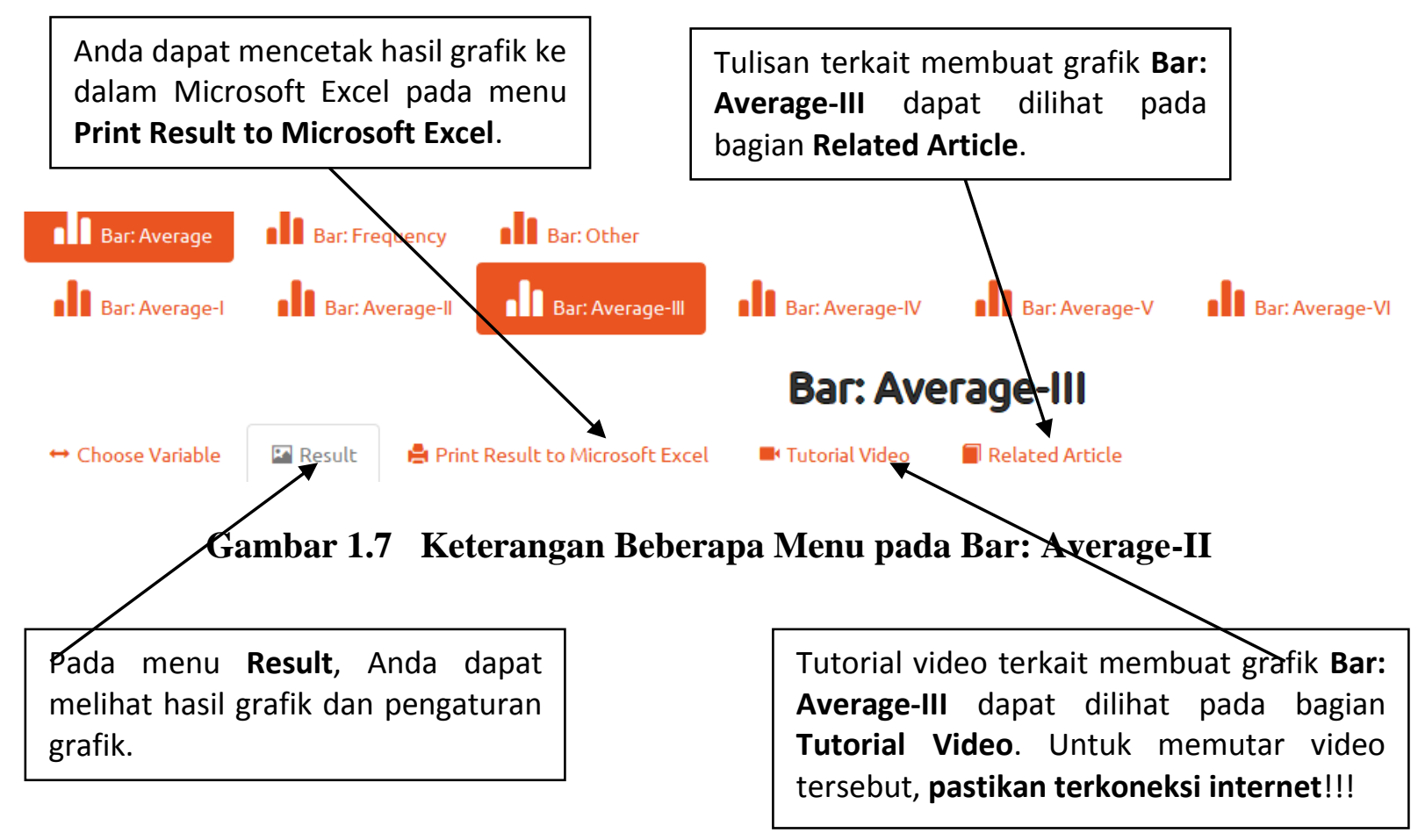


Gambar 1.8 disajikan grafik batang rata-rata.

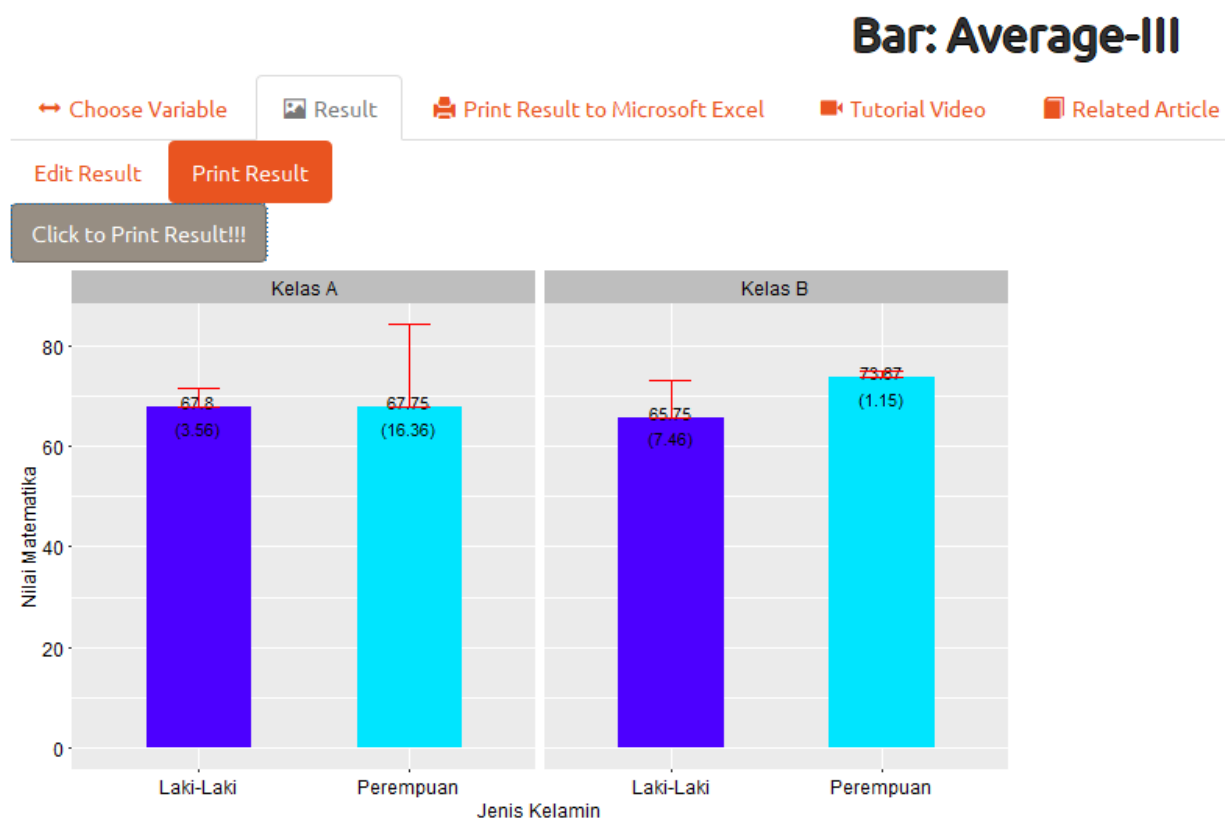

Gambar 1.8 Grafik Batang Rata-Rata 


\section{Mengolah Data dengan} Program Aplikasi Statistika

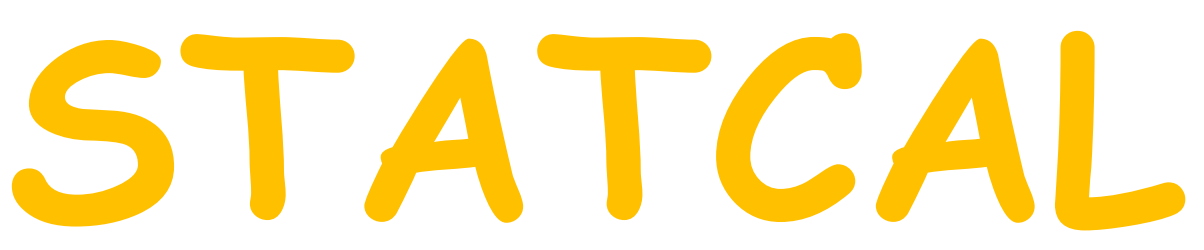

Membuat Grafik Batang Rata-Rata dengan Menu

$$
\text { Bar: Average-IV }
$$

Oleh Prana Ugiana Gio

Founder \& CEO STATCAL

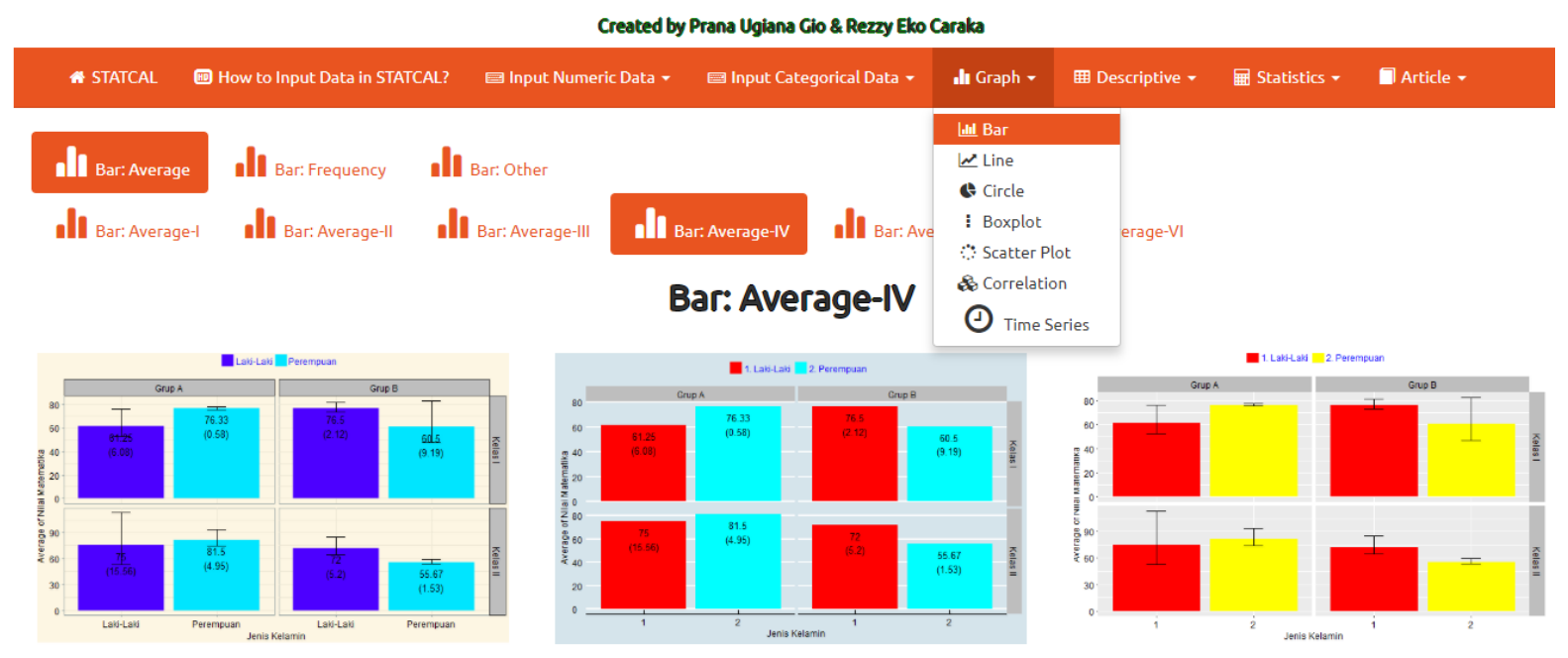


Misalkan diberikan data nilai ujian matematika berdasarkan jenis kelamin, kelas dan grup (Tabel $1.1)$.

\section{Tabel 1.1 Data Nilai Ujian Matematika berdasarkan Jenis Kelamin, Kelas dan Grup (Data Fiktif)}

\begin{tabular}{|c|c|c|c|c|}
\hline Nama & Jenis Kelamin & Kelas & Grup & Nilai Matematika \\
\hline Andi & 1 & 1 & 1 & 67 \\
\hline Ugi & 1 & 2 & 1 & 86 \\
\hline Egi & 1 & 1 & 1 & 66 \\
\hline Ardi & 1 & 1 & 1 & 56 \\
\hline Ahmad & 1 & 2 & 2 & 75 \\
\hline Dori & 1 & 2 & 2 & 66 \\
\hline Dani & 1 & 1 & 2 & 78 \\
\hline Rudi & 1 & 1 & 2 & 75 \\
\hline Ahong & 1 & 2 & 1 & 64 \\
\hline Didi & 1 & 1 & 1 & 56 \\
\hline Danu & 1 & 2 & 2 & 75 \\
\hline Fitri & 2 & 1 & 1 & 76 \\
\hline Fini & 2 & 1 & 2 & 67 \\
\hline Fani & 2 & 1 & 1 & 76 \\
\hline Rini & 2 & 2 & 2 & 56 \\
\hline Rina & 2 & 2 & 1 & 78 \\
\hline Tantri & 2 & 2 & 2 & 54 \\
\hline Tuti & 2 & 1 & 2 & 57 \\
\hline Siti & 2 & 2 & 1 & 2 \\
\hline Sinta & 2 & 1 & 2 & 2 \\
\hline Titik & 2 & 1 & 2 & 2 \\
\hline
\end{tabular}

\begin{tabular}{|c|c|c|c|}
\hline Angka & Jenis Kelamin & Kelas & Grup \\
\hline 1 & Laki-Laki & Kelas I & Grup A \\
\hline 2 & Perempuan & Kelas II & Grup B \\
\hline
\end{tabular}

Berdasarkan data pada Tabel 1.1, diketahui siswa yang bernama Ugi, dengan jenis kelamin lakilaki, kelas II, grup A, memperoleh nilai matematika 86. Dari data pada Tabel 1.1, disajikan grafik batang rata-rata seperti pada Gambar 1.1. 


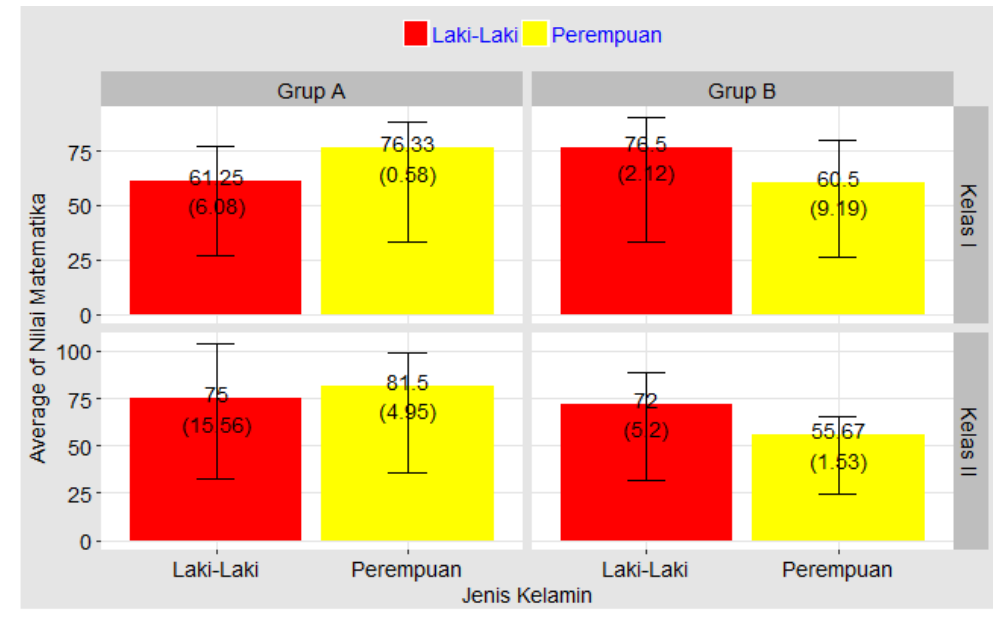

Gambar 1.1 Grafik Batang Rata-Rata

Berdasarkan grafik batang rata-rata pada Gambar 1.1, diketahui:

$\Rightarrow$ Rata-rata nilai matematika dari kelas I, grup A, laki-laki, adalah 61,25, dengan standar deviasi 6,08. Sementara nilai rata-rata matematika dari kelas I, grup A, perempuan, adalah 76,33, dengan standar deviasi 0,58.

$\Rightarrow$ Rata-rata nilai matematika dari kelas II, grup A, laki-laki, adalah 75, dengan standar deviasi 15,56. Sementara nilai rata-rata matematika dari kelas II, grup A, perempuan, adalah 81,5 , dengan standar deviasi 4,95 .

Untuk membuat grafik batang rata-rata pada Gambar 1.1, kita akan menggunakan menu Bar: Average-IV (Gambar 1.2).

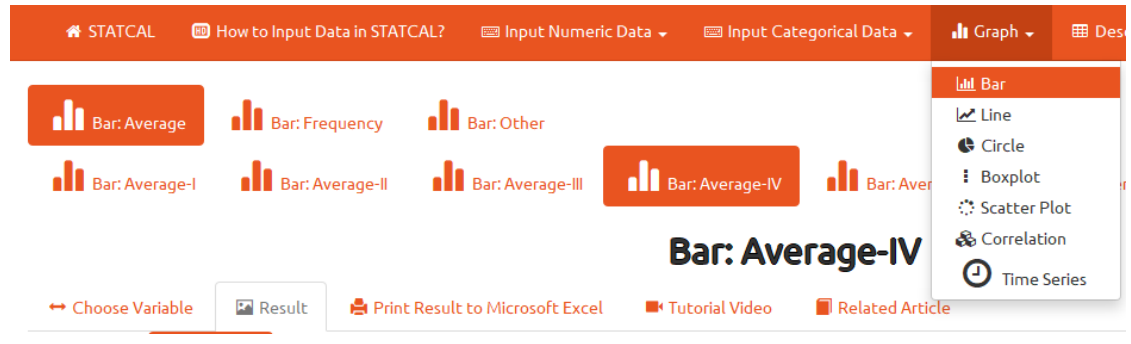

Gambar 1.2 Menu Bar: Average-IV 
Langkah pertama adalah input data pada Tabel 1.1 ke dalam STATCAL seperti pada Gambar 1.3 (input data numerik) dan Gambar 1.4 (input data kategori). Selanjutnya kita akan mengakses menu Bar: Average-IV dengan memilih Graph => Bar => Bar: Average => Bar: Average-IV (Gambar 1.5).

\section{N STATCAL How to Input Data in STATCAL? 回 Input Numeric Data - 回 Input Categorical Data v In}

Input Numeric Data

\section{Numeric Data}

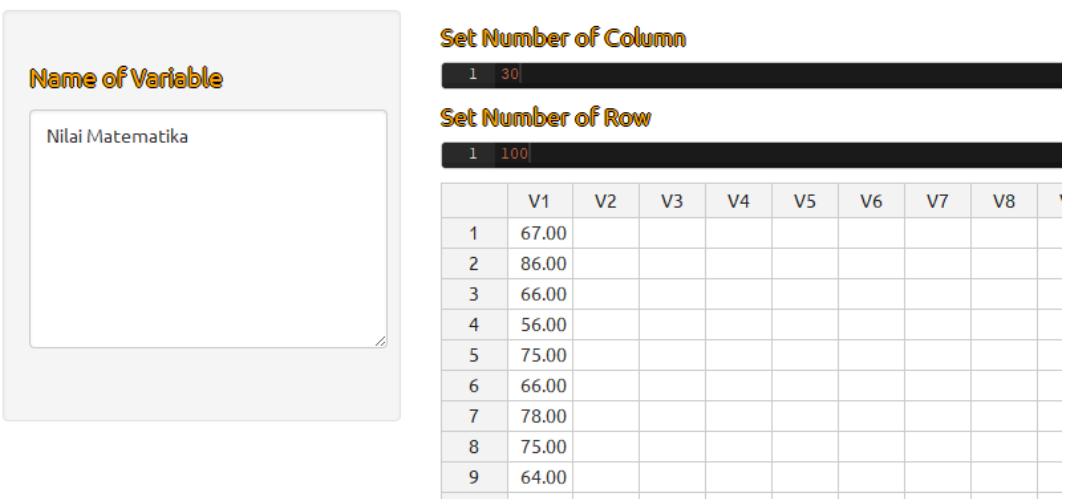

Gambar 1.3 Input Data Numerik
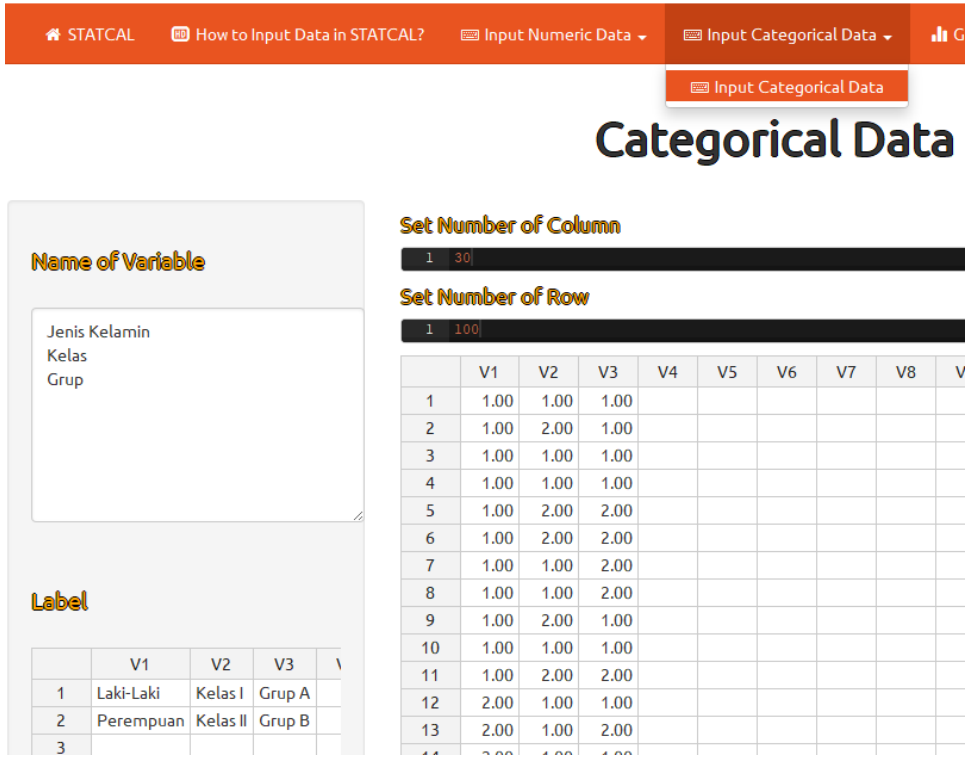

Gambar 1.4 Input Data Kategori 


\begin{tabular}{|c|c|c|c|c|}
\hline Dhar: Average & Bar: Frequency & If Bar: Other & & \\
\hline Bar: Average-I & D Bar: Average-II & al| Bar: Average-III & Bar: Average-IV & alf Bar: Average \\
\hline & & & Bar: A & IV \\
\hline oose Variable & Result & Result to Microsoft Exce & - Tutorial Video & 7 Related Article \\
\hline
\end{tabular}

\section{Gambar 1.5 Menu Bar: Average-IV}

Pada Gambar 1.6, masukkan variabel seperti pada Gambar 1.6.

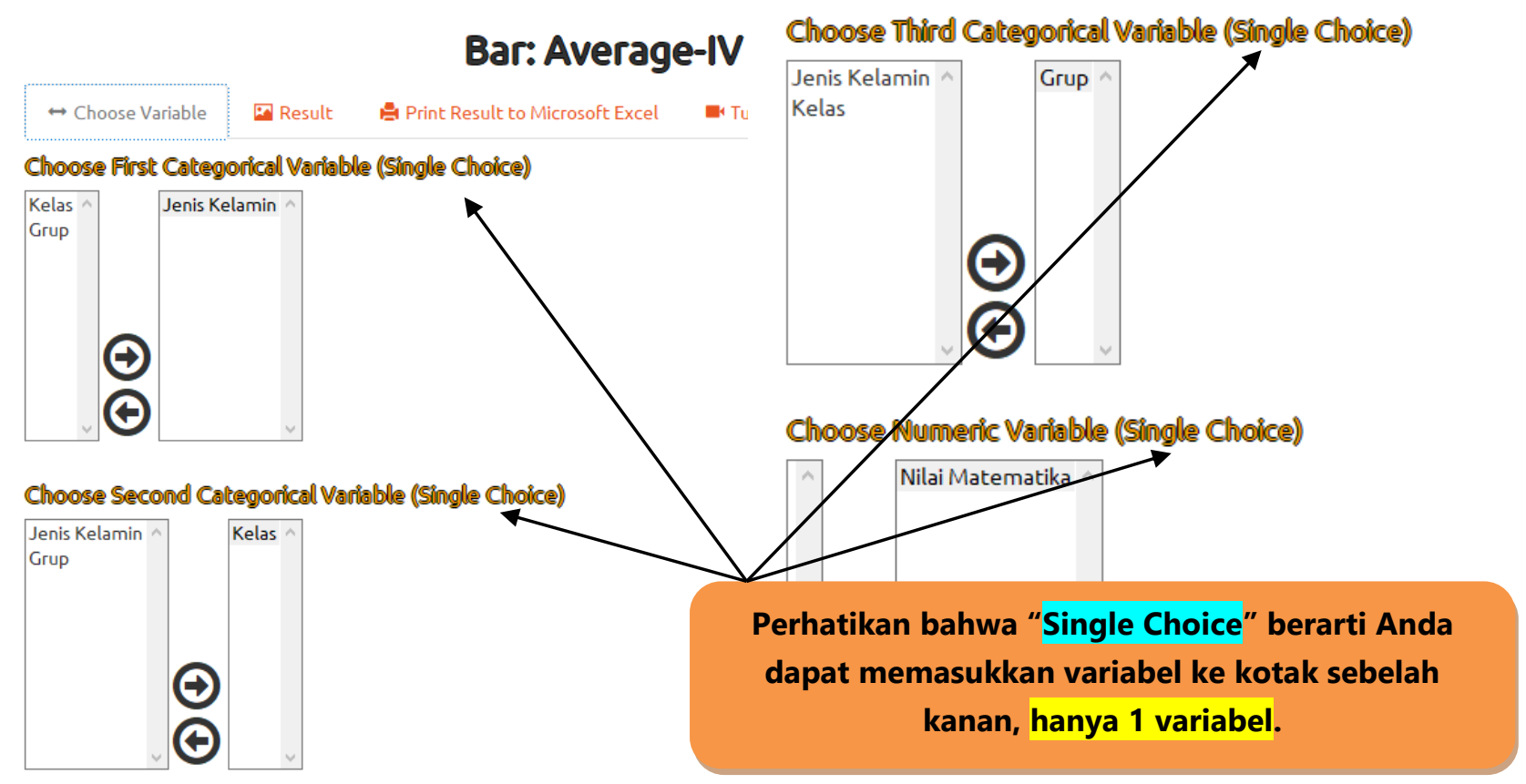

Gambar 1.6 Pemilihan Variabel

Gambar 1.7 merupakan keterangan beberapa menu pada Bar: Average-IV. 


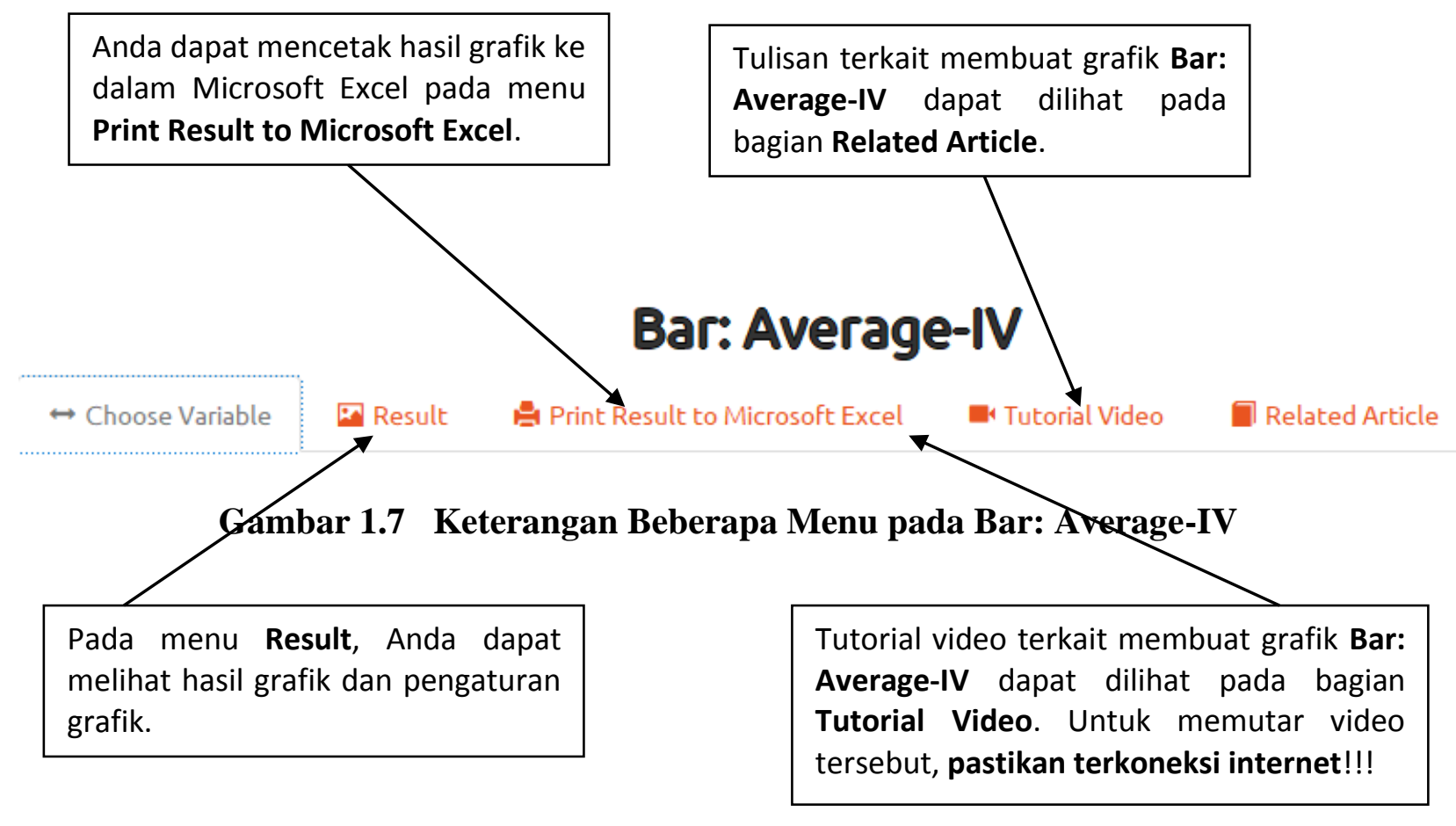

Gambar 1.8 disajikan grafik batang rata-rata.

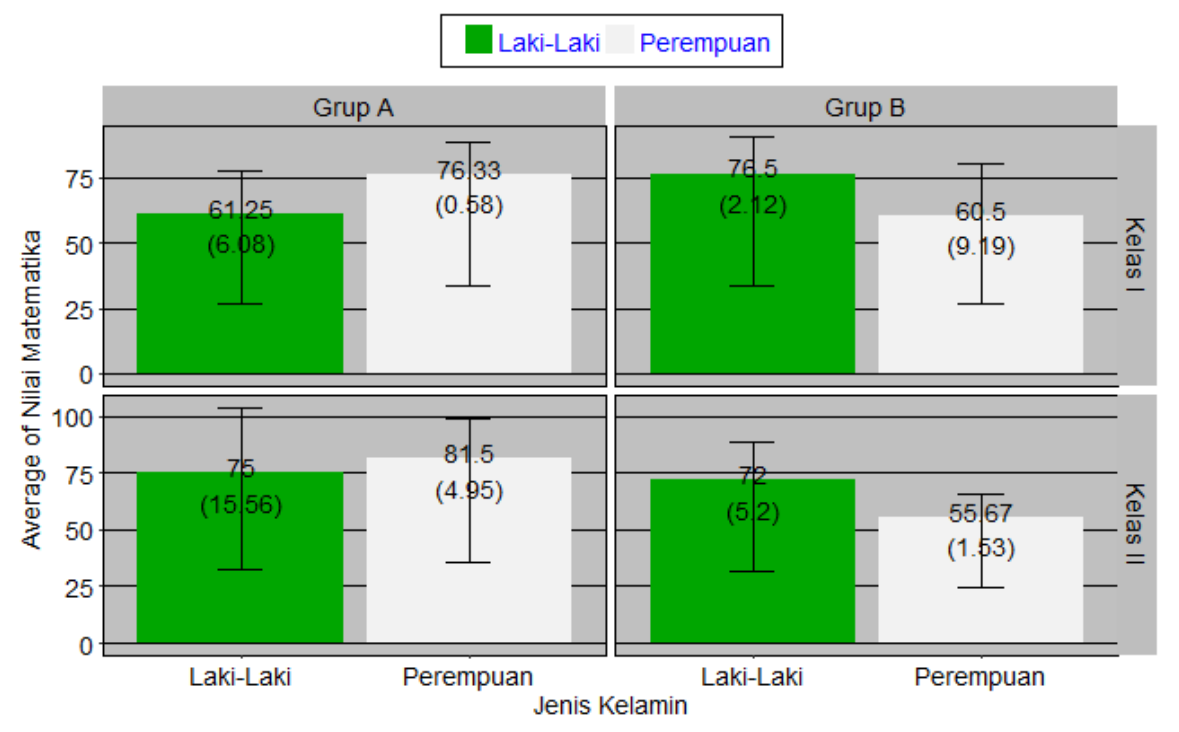

Gambar 1.8 Grafik Batang Rata-Rata 


\section{Mengolah Data dengan} Program Aplikasi Statistika

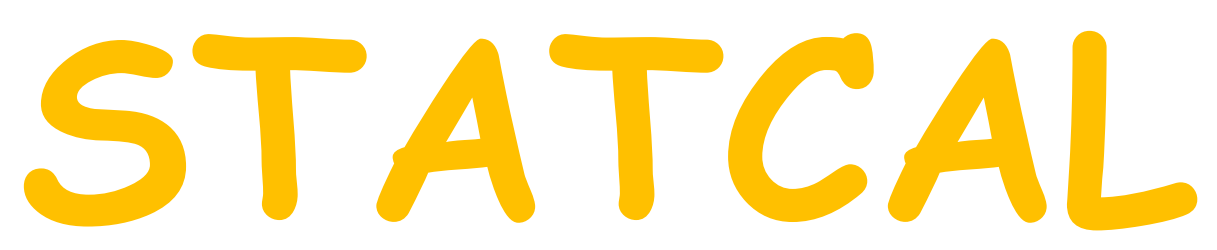

Membuat Grafik Batang Rata-Rata dengan Menu

$$
\text { Bar: Average-V }
$$

Oleh Prana Ugiana Gio

Founder \& CEO STATCAL

Created by Prana Ugiana Gio \& Rezzy Eko Caraka

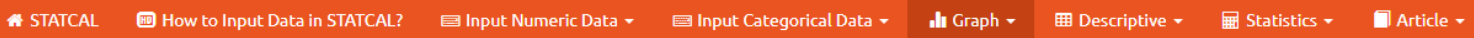

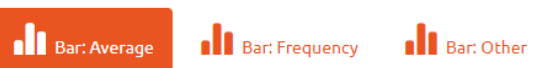

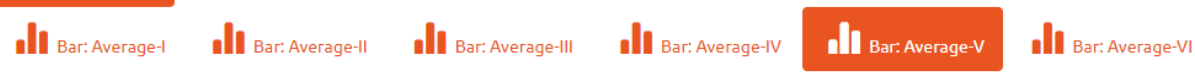

Bar: Average-V
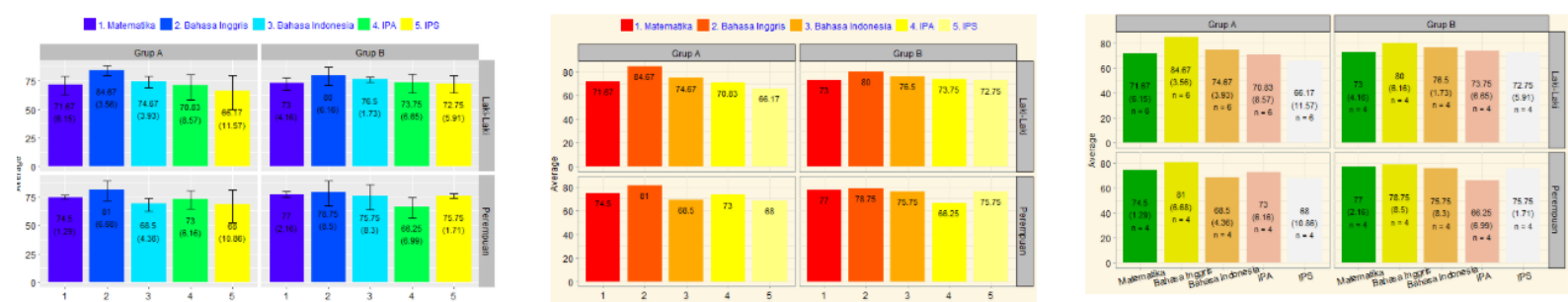
Misalkan diberikan data nilai ujian matematika, bahasa inggris, bahasa Indonesia, IPA dan IPS, berdasarkan jenis kelamin dan grup (Tabel 1.1).

Tabel 1.1 Data Nilai Ujian Matematika, Bahasa Inggris, Bahasa Indonesia, IPA dan IPS berdasarkan Jenis Kelamin dan Grup (Data Fiktif)

\begin{tabular}{|c|c|c|c|c|c|c|c|}
\hline Nama & Jenis Kelamin & Grup & Matematika & Bahasa Inggris & Bahasa Indonesia & IPA & IPS \\
\hline Andi & 1 & 1 & 75 & 87 & 76 & 77 & 75 \\
\hline Ugi & 1 & 1 & 77 & 85 & 77 & 65 & 45 \\
\hline Egi & 1 & 2 & 78 & 78 & 78 & 64 & 64 \\
\hline Arman & 1 & 1 & 65 & 88 & 75 & 56 & 67 \\
\hline Doni & 1 & 2 & 74 & 89 & 75 & 78 & 77 \\
\hline Beni & 1 & 1 & 79 & 86 & 78 & 76 & 78 \\
\hline Roy & 1 & 2 & 72 & 75 & 75 & 78 & 75 \\
\hline Vino & 1 & 1 & 65 & 78 & 67 & 74 & 65 \\
\hline Tarno & 1 & 2 & 68 & 78 & 78 & 75 & 75 \\
\hline Roki & 1 & 1 & 69 & 84 & 75 & 77 & 67 \\
\hline Rina & 2 & 1 & 74 & 75 & 66 & 78 & 65 \\
\hline Rini & 2 & 2 & 77 & 78 & 65 & 74 & 78 \\
\hline Dini & 2 & 1 & 73 & 89 & 67 & 64 & 75 \\
\hline Riri & 2 & 2 & 78 & 85 & 85 & 57 & 74 \\
\hline Rita & 2 & 1 & 75 & 84 & 66 & 75 & 78 \\
\hline Sari & 2 & 2 & 79 & 85 & 78 & 67 & 75 \\
\hline Furi & 2 & 2 & 74 & 67 & 75 & 67 & 76 \\
\hline Sinta & 2 & 1 & 76 & 76 & 75 & 75 & 54 \\
\hline
\end{tabular}

\begin{tabular}{|c|c|c|}
\hline Angka & Jenis Kelamin & Grup \\
\hline 1 & Laki-Laki & Grup A \\
\hline 2 & Perempuan & Grup B \\
\hline
\end{tabular}

Berdasarkan data pada Tabel 1.1, diketahui siswa yang bernama Ugi, dengan jenis kelamin lakilaki, dari grup A, memperoleh nilai matematika 77, bahasa inggris 85, bahasa Indonesia 77, IPA 65 dan IPS 45. Dari data pada Tabel 1.1, disajikan grafik batang rata-rata seperti pada Gambar 1.1. 


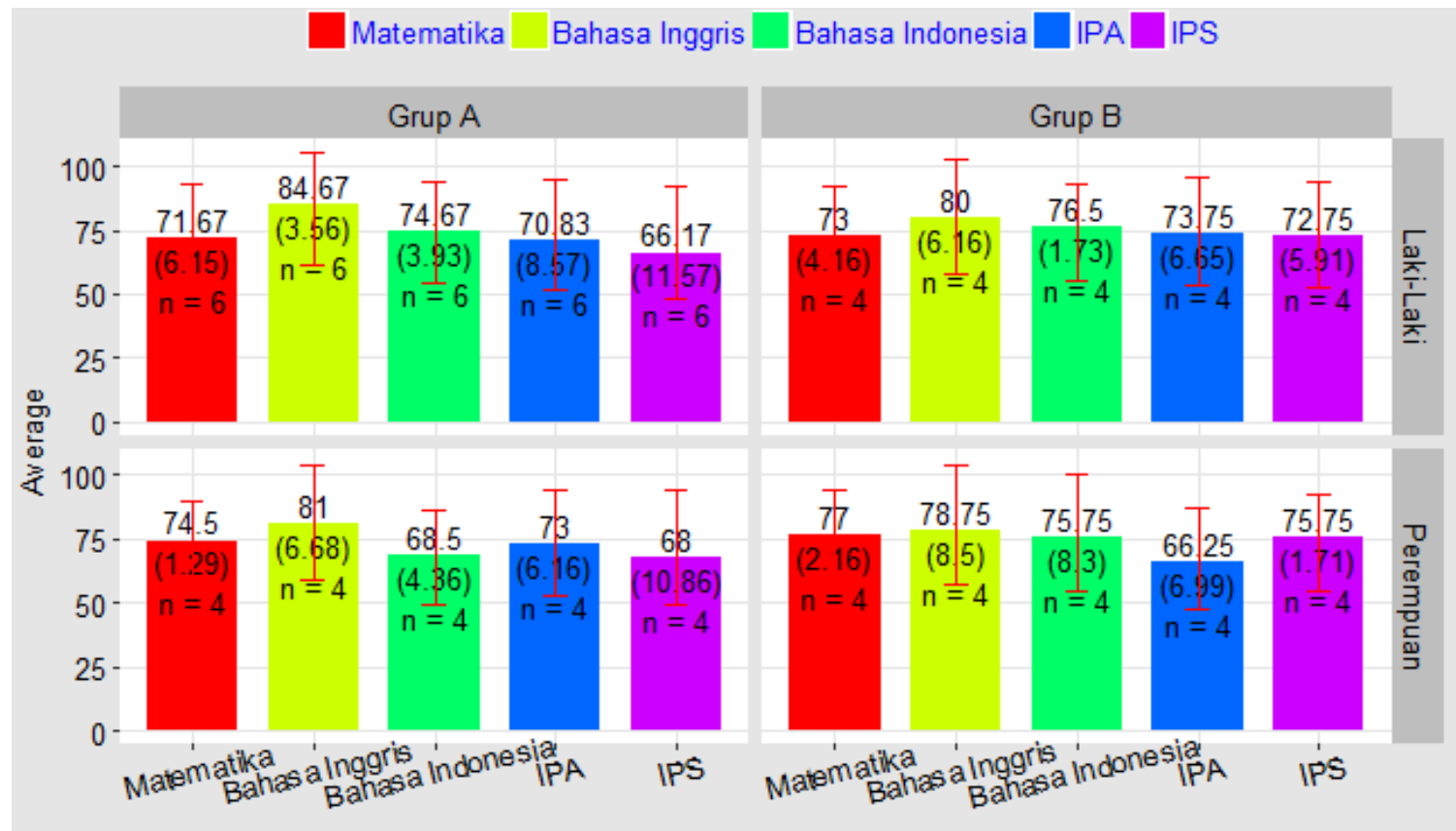

Gambar 1.1 Grafik Batang Rata-Rata

Berdasarkan grafik batang rata-rata pada Gambar 1.1, diketahui:

$\Rightarrow$ Rata-rata nilai matematika laki-laki dari grup A adalah 71,67, dengan standar deviasi 6,15. Jumlah siswa laki-laki dari grup A sebanyak 6 siswa.

$\Rightarrow$ Rata-rata nilai matematika perempuan dari grup A adalah 74,5, dengan standar deviasi 1,29. Jumlah siswa perempuan dari grup A sebanyak 4 siswa.

Untuk membuat grafik batang rata-rata pada Gambar 1.1, kita akan menggunakan menu Bar: Average-V (Gambar 1.2).

If Bar: Average all Bar: Frequency all Bar: Other

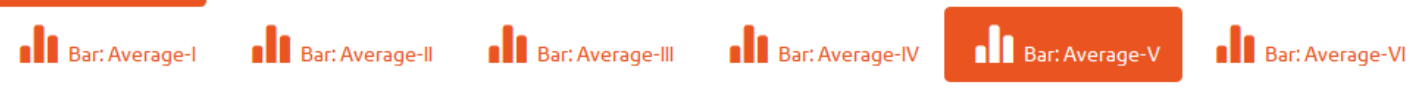
Bar: Average-V

Gambar 1.2 Menu Bar: Average-V 
Langkah pertama adalah input data pada Tabel 1.1 ke dalam STATCAL seperti pada Gambar 1.3 (input data numerik) dan Gambar 1.4 (input data kategori). Selanjutnya kita akan mengakses menu Bar: Average-V dengan memilih Graph => Bar => Bar: Average => Bar: Average-V (Gambar 1.5).

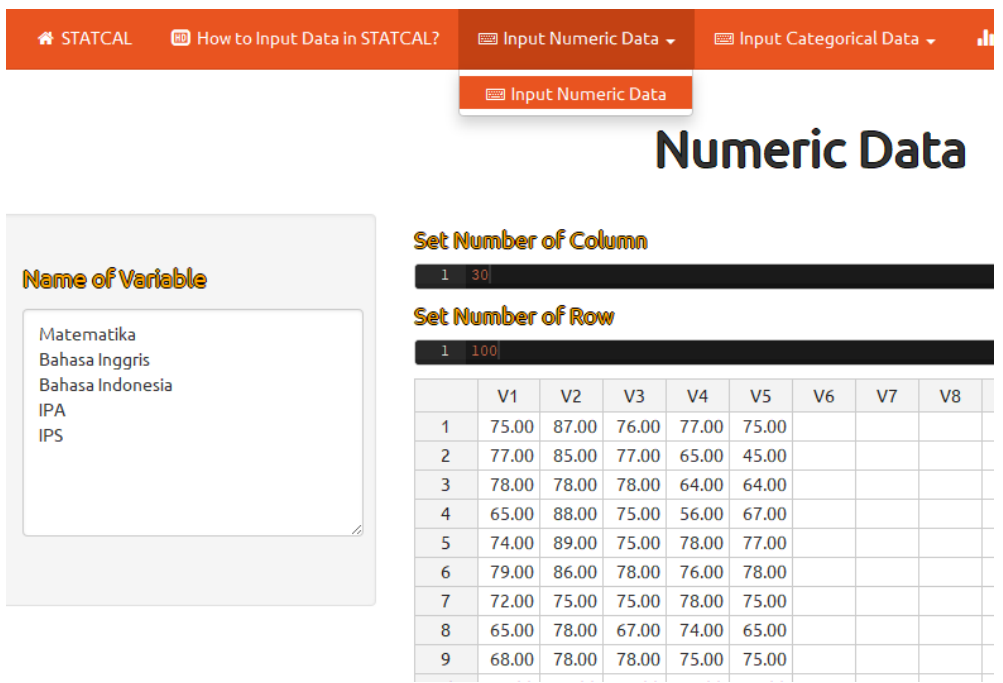

\section{Gambar 1.3 Input Data Numerik}

* STATCAL How to Input Data in STATCAL? 回 Input Numeric Data - 回 Input Categorical Data v Il C 國 Input Categorical Data

\section{Categorical Data}

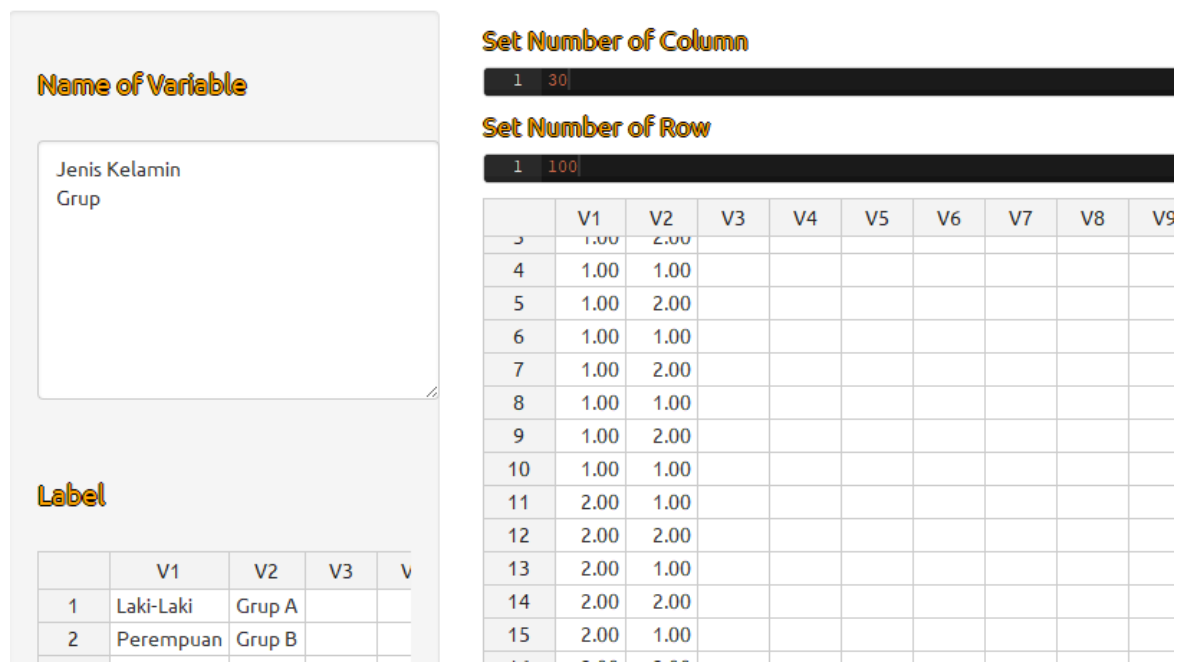

Gambar 1.4 Input Data Kategori 


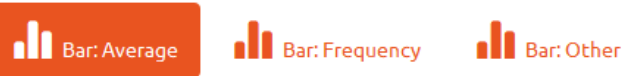
ill Ba:Averager
Ill Bar:Average-|l
Ill вar:Average-lil
ill Bar:Averge-

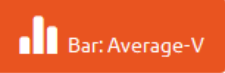
III вar:Average-VI

\section{Bar: Average-V}

\section{Gambar 1.5 Menu Bar: Average-V}

Pada Gambar 1.6, masukkan variabel seperti pada Gambar 1.6.

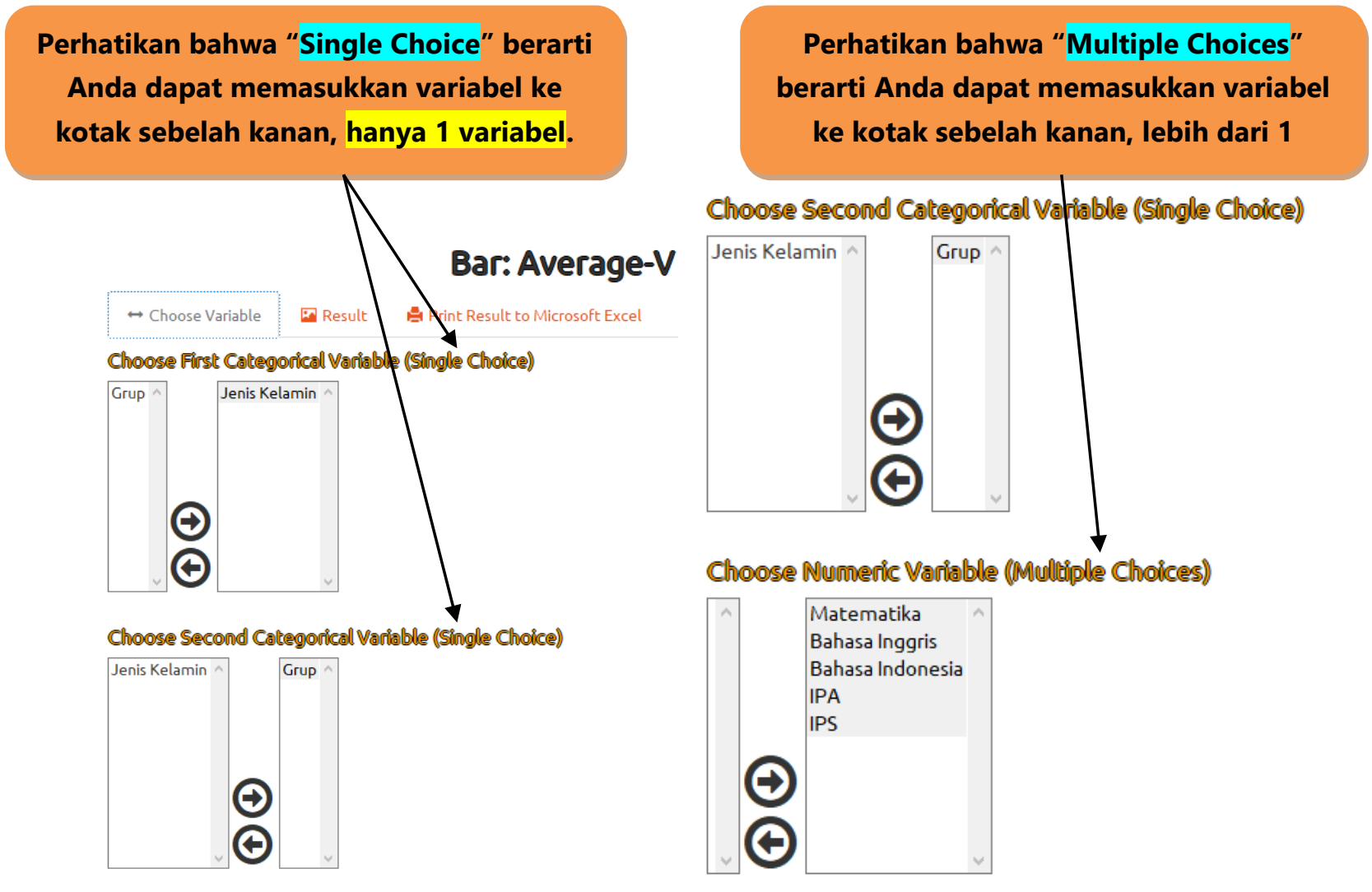

Gambar 1.6 Pemilihan Variabel

Gambar 1.7 merupakan keterangan beberapa menu pada Bar: Average-V. 


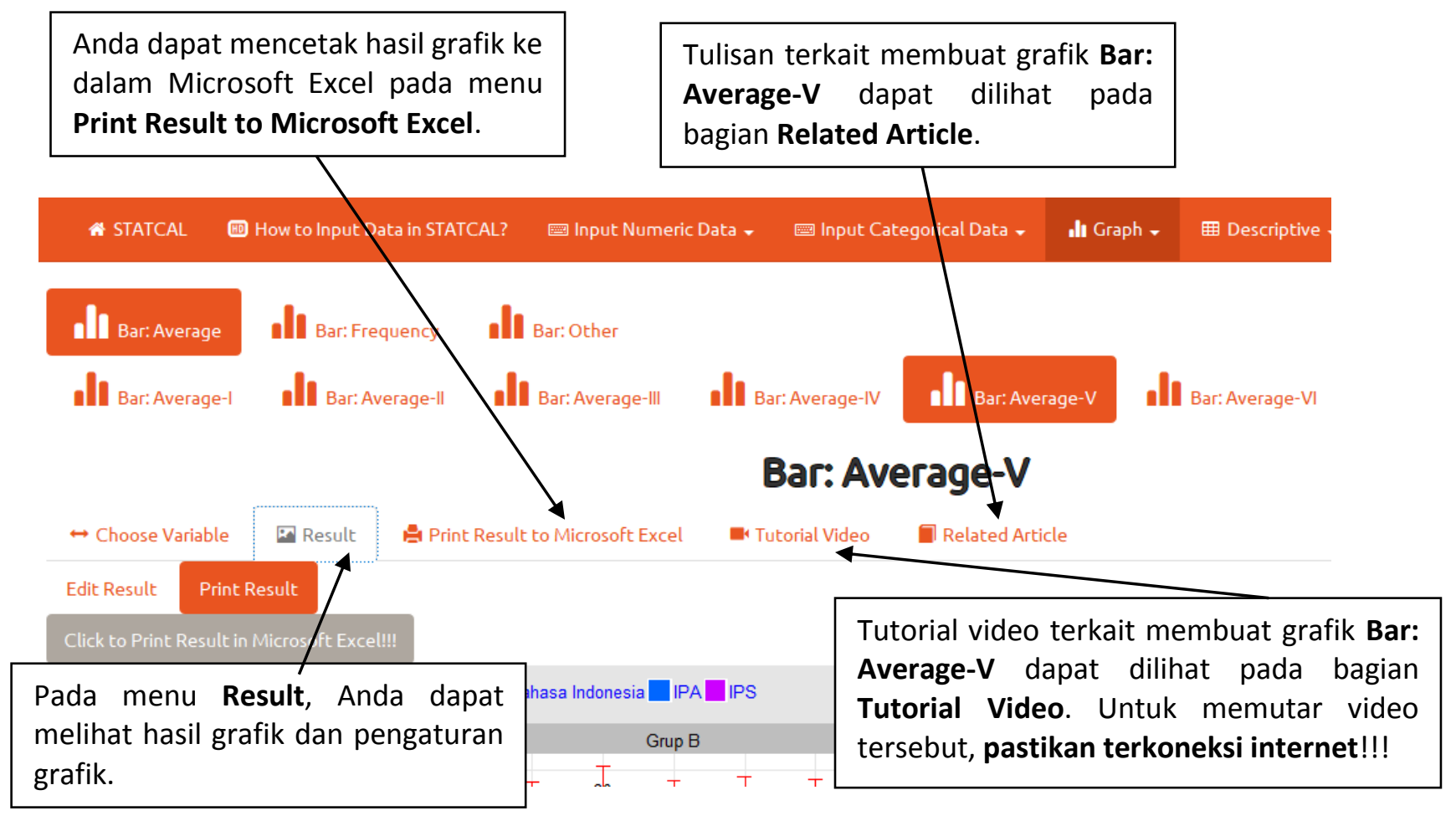

Gambar 1.7 Keterangan Beberapa Menu pada Bar: Average-V

Gambar 1.8 disajikan grafik batang rata-rata.

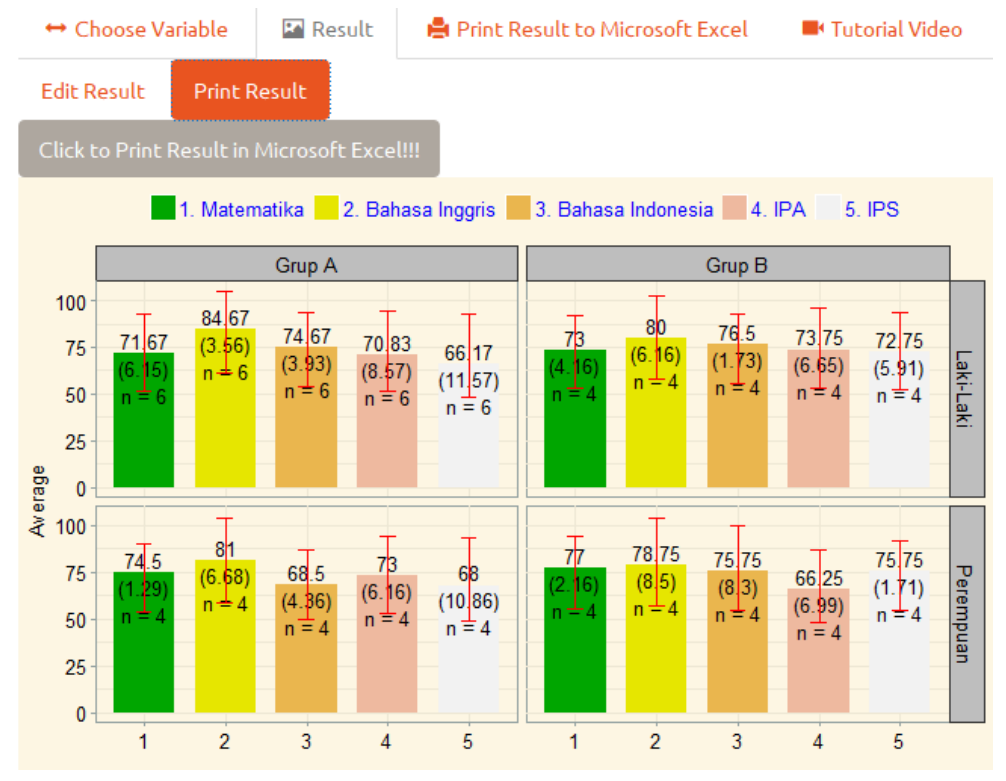

Gambar 1.8 Grafik Batang Rata-Rata 


\section{Mengolah Data dengan}

Program Aplikasi Statistika

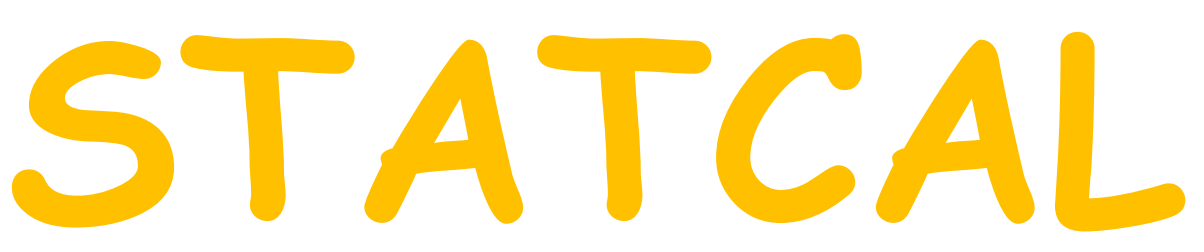

Membuat Grafik Batang Frekuensi dengan Menu

Bar: Frequency-I

Oleh Prana Ugiana Gio

Founder \& CEO STATCAL

Created by Prana Ugiana Gio \& Rezzy Eko Caraka

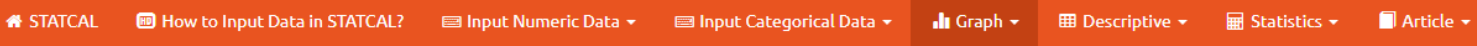

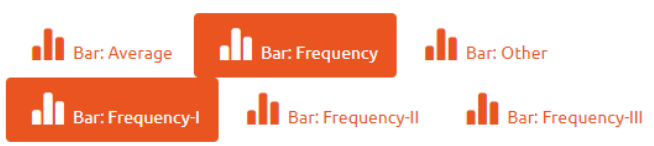

Bar: Frequency-1
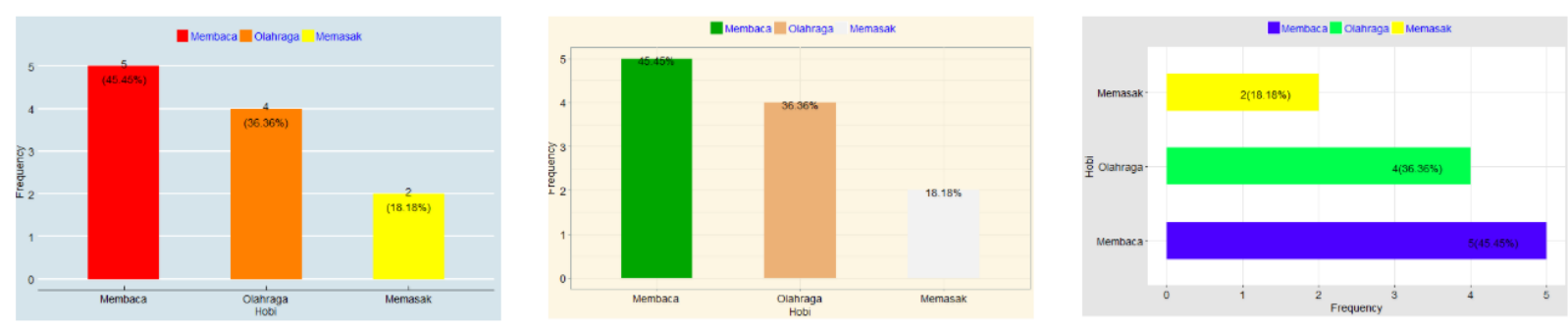
Misalkan diberikan data hobi dari 11 responden (Tabel 1.1).

Tabel 1.1 Data Hobi dari 11 Responden (Data Fiktif)

\begin{tabular}{|c|c|}
\hline Nama & Hobi \\
\hline Ugi & 1 \\
\hline Egi & 2 \\
\hline Andi & 3 \\
\hline Edi & 1 \\
\hline Rina & 1 \\
\hline Rini & 2 \\
\hline Suci & 2 \\
\hline Ani & 1 \\
\hline Fitri & 1 \\
\hline Tini & 2 \\
\hline Andi & 3 \\
\hline
\end{tabular}

\begin{tabular}{|c|c|}
\hline Angka & Hobi \\
\hline 1 & Membaca \\
\hline 2 & Olahraga \\
\hline 3 & Memasak \\
\hline
\end{tabular}

Berdasarkan data pada Tabel 1.1, diketahui responden yang bernama Ugi memiliki hobi membaca, responden yang bernama Egi memiliki hobi olahraga, dan seterusnya. Dari data pada Tabel 1.1, disajikan grafik batang frekuensi seperti pada Gambar 1.1.

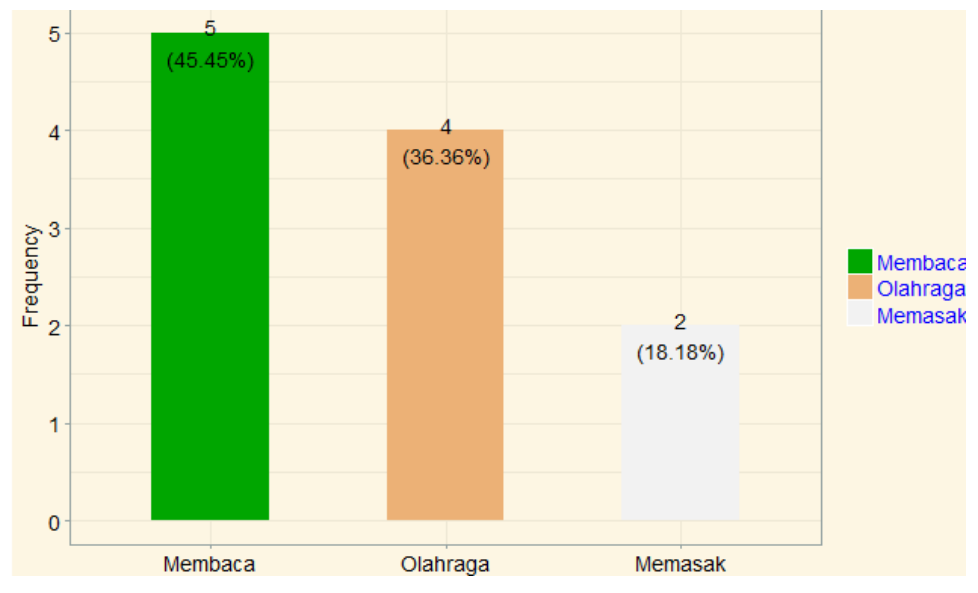

Gambar 1.1 Grafik Batang Frekuensi 
Berdasarkan grafik batang frekuensi pada Gambar 1.1, diketahui:

$\Rightarrow$ Jumlah responden dengan hobi membaca sebanyak $5(45,45 \%)$ responden.

$\Rightarrow$ Jumlah responden dengan hobi olahraga sebanyak $4(36,36 \%)$ responden.

$\Rightarrow$ Jumlah responden dengan hobi memasak sebanyak $2(18,18 \%)$ responden.

Untuk membuat grafik batang frekuensi pada Gambar 1.1, kita akan menggunakan menu Bar: Frequency-I (Gambar 1.2).

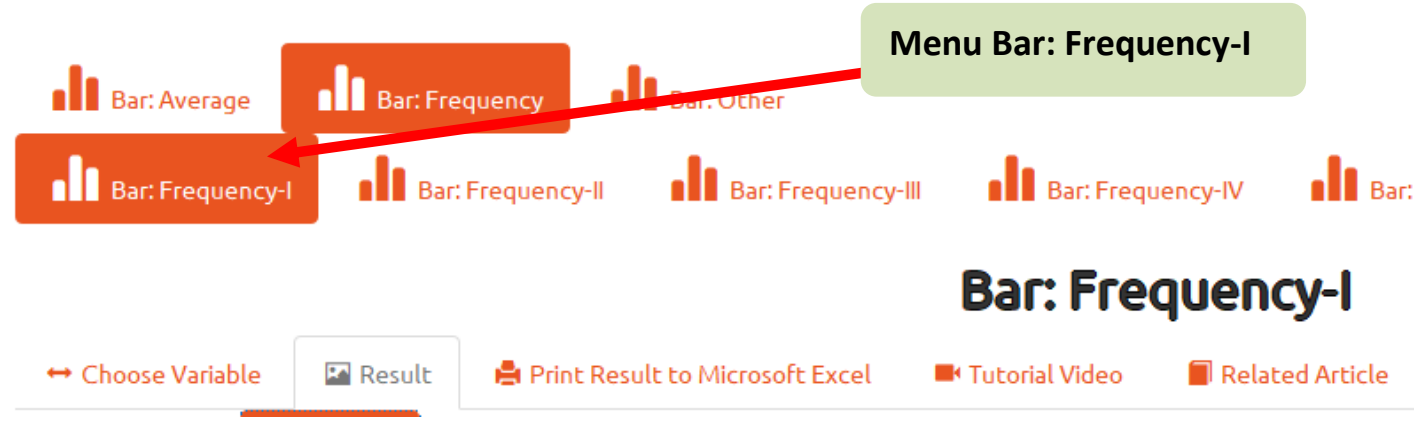

Gambar 1.2 Menu Bar: Frequency-I

Langkah pertama adalah input data pada Tabel 1.1 ke dalam STATCAL seperti pada Gambar 1.3. Perhatikan bahwa data diinput pada bagian Input Categorical Data. Selanjutnya kita akan mengakses menu Bar: Frequency-I dengan memilih Graph $=>$ Bar $=>$ Bar: Frequency $=>$ Bar: Frequency-I (Gambar 1.4). 


\section{Categorical Data}

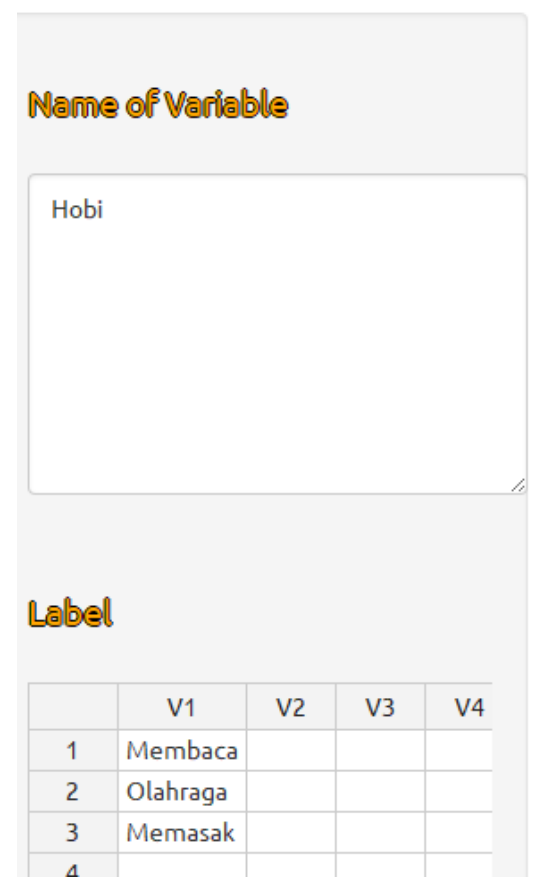

\section{Set Numober of Colunon}

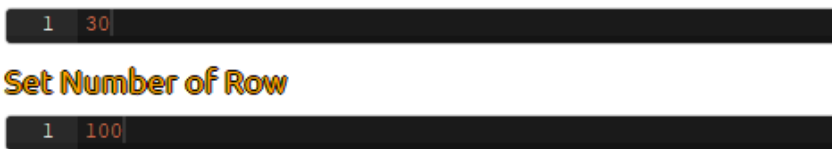

\begin{tabular}{|c|c|c|c|c|c|c|c|c|c|}
\hline & V1 & V2 & V3 & V4 & V5 & V6 & V7 & V8 & 1 \\
\hline 1 & 1.00 & & & & & & & & \\
\hline 2 & 2.00 & & & & & & & & \\
\hline 3 & 3.00 & & & & & & & & \\
\hline 4 & 1.00 & & & & & & & & \\
\hline 5 & 1.00 & & & & & & & & \\
\hline 6 & 2.00 & & & & & & & & \\
\hline 7 & 2.00 & & & & & & & & \\
\hline 8 & 1.00 & & & & & & & & \\
\hline 9 & 1.00 & & & & & & & & \\
\hline 10 & 2.00 & & & & & & & & \\
\hline 11 & 3.00 & & & & & & & & \\
\hline \multicolumn{10}{|c|}{12} \\
\hline \multicolumn{10}{|c|}{13} \\
\hline 14 & & & & & & & & & \\
\hline
\end{tabular}

Gambar 1.3 Input Data Kategori pada Bagian Input Categorical Data

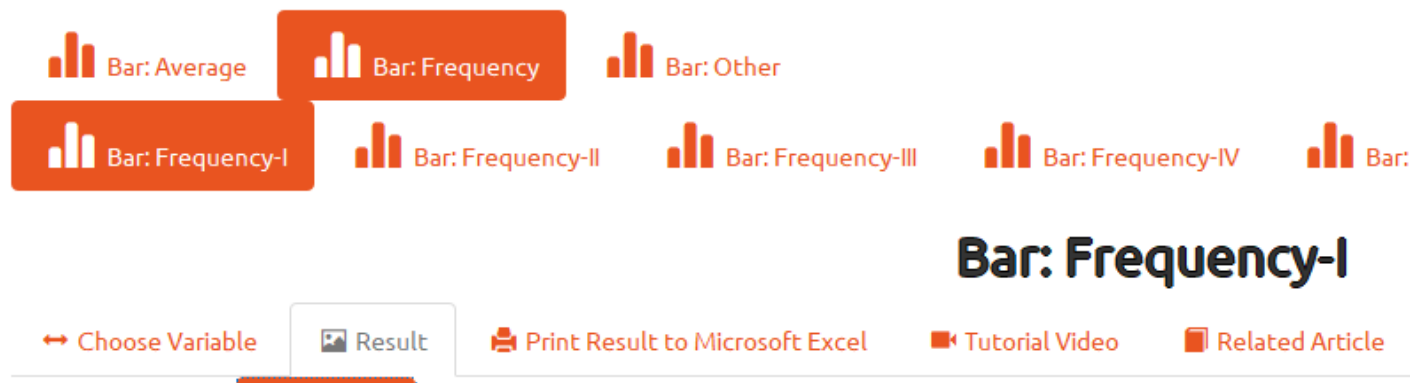

Gambar 1.4 Menu Bar: Frequency-I 
Pada Gambar 1.5, pindahkan variabel hobi ke kotak sebelah kanan.

\section{Bar: Frequency-1}

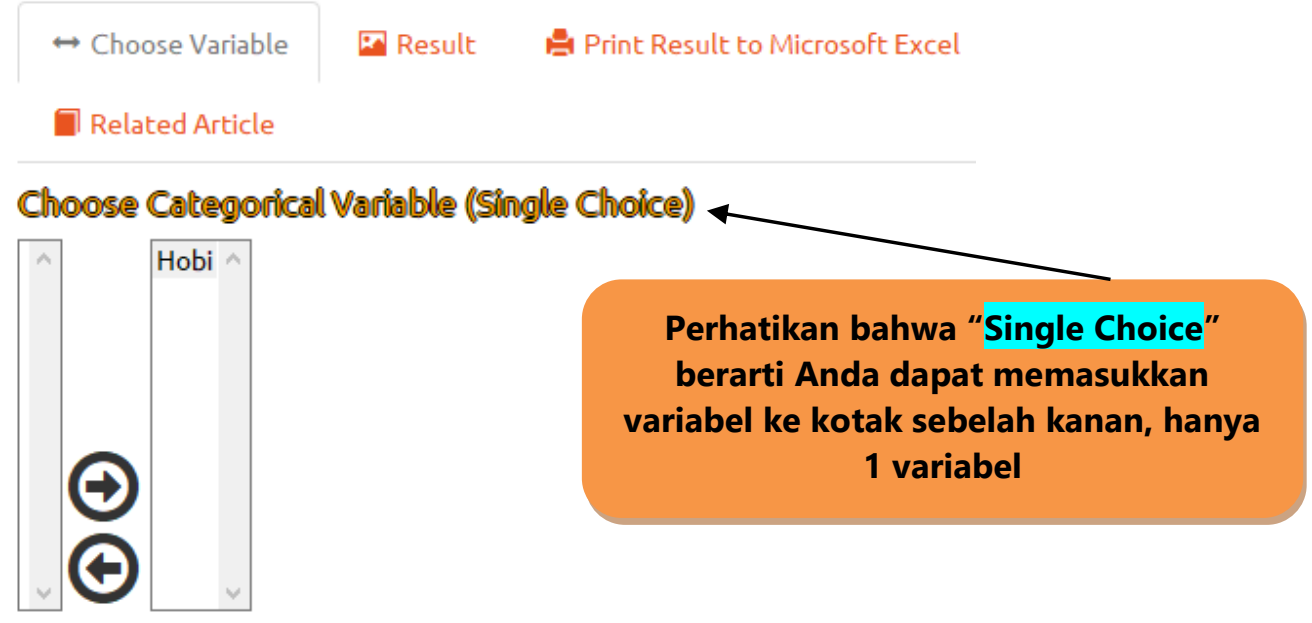

\section{Gambar 1.5 Pemilihan Variabel}

Gambar 1.6 merupakan keterangan beberapa menu pada Bar: Frequency-I.

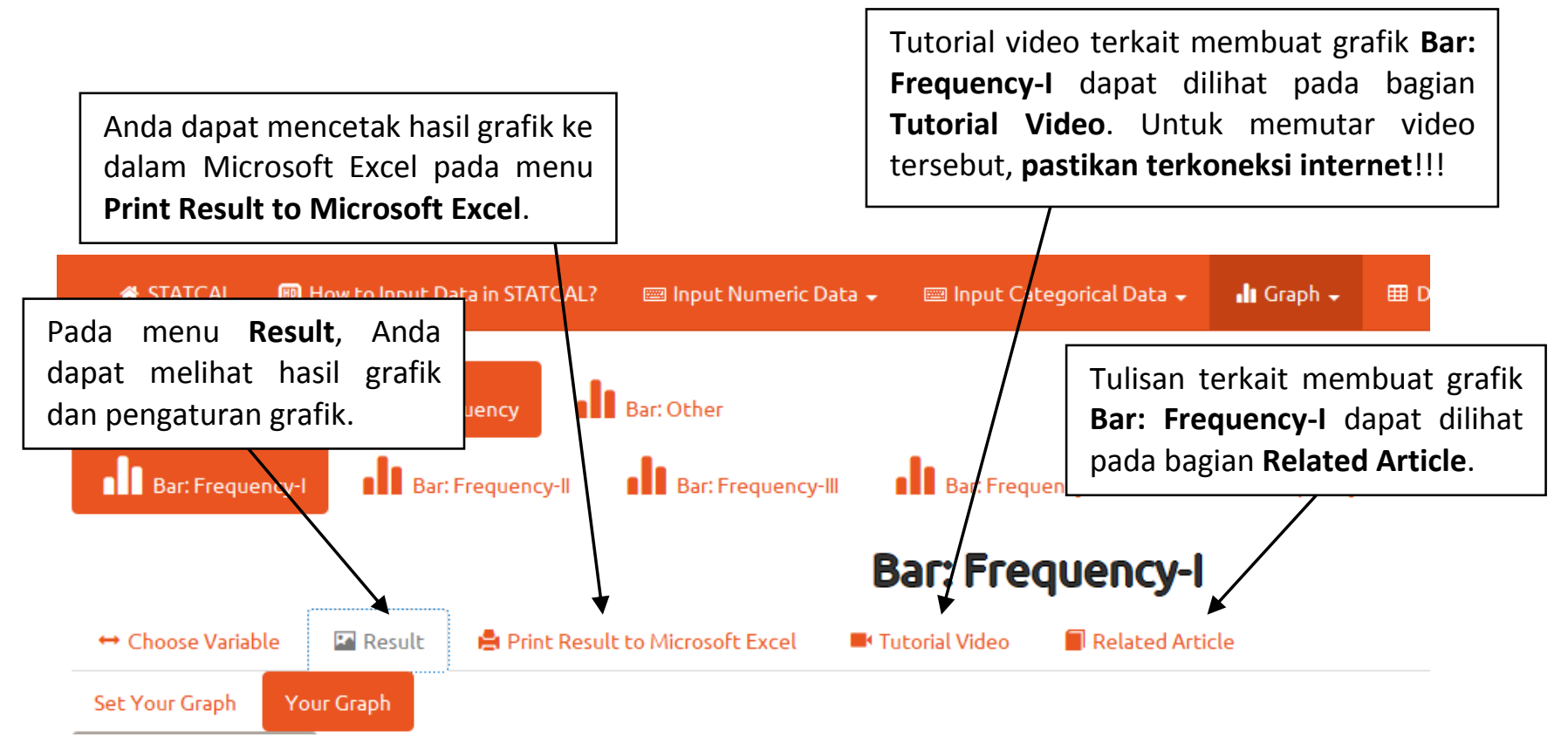

Gambar 1.6 Keterangan Beberapa Menu pada Bar: Frequency-I 
Gambar 1.7 disajikan grafik batang frekuensi.

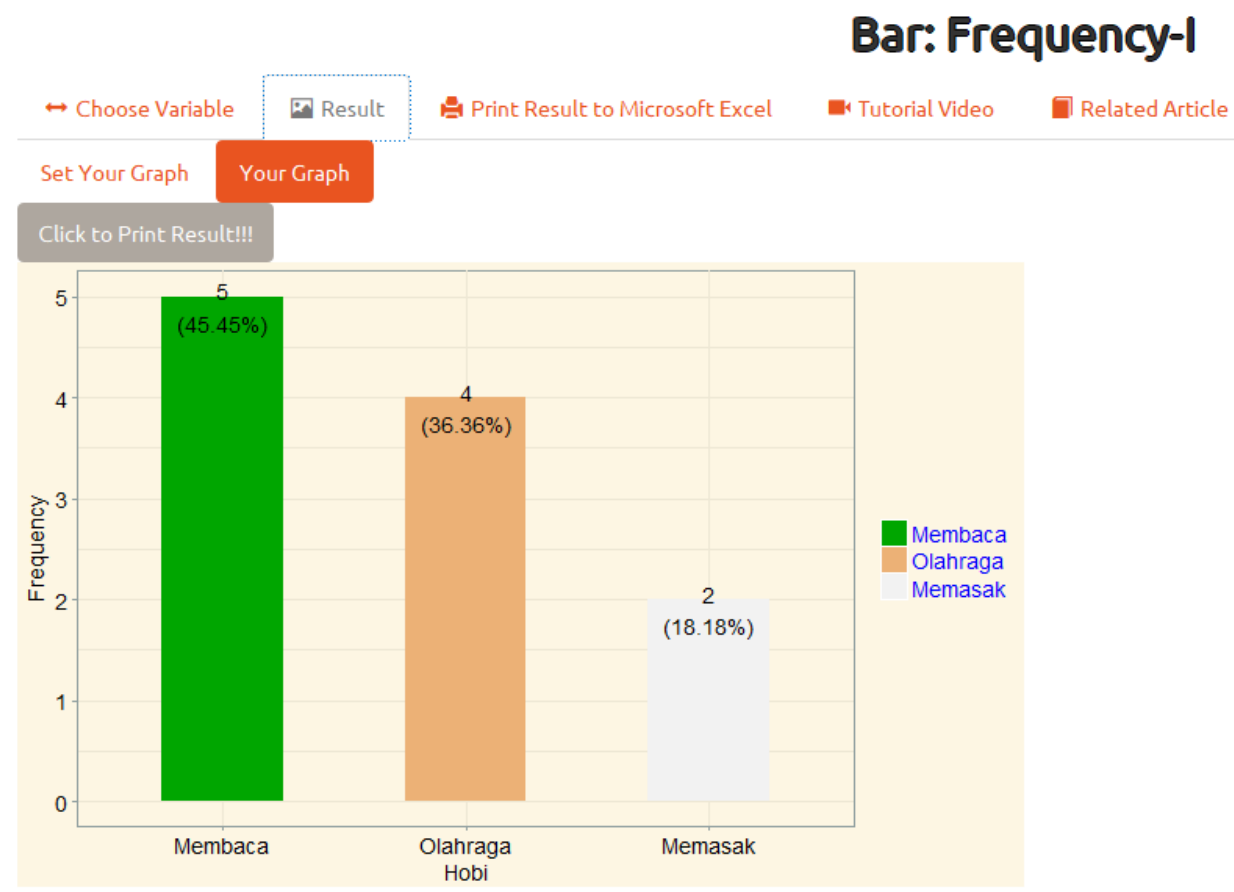

Gambar 1.7 Grafik Batang Frekuensi 


\section{Mengolah Data dengan}

Program Aplikasi Statistika
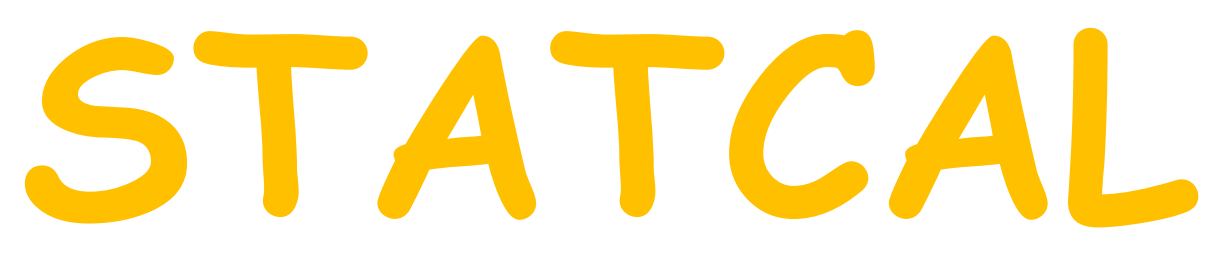

Membuat Grafik Batang Frekuensi dengan Menu

Bar: Frequency-II

\section{Oleh Prana Ugiana Gio}

Founder \& CEO STATCAL

Created by Prana Ugiana Gio \& Rezzy Eko Caraka

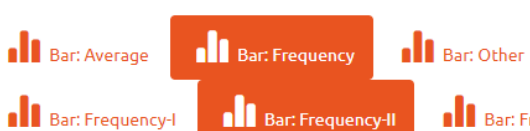

Bar: Frequency-1 of Bar: Frequency-II 1 Bar: Frequency-III

Bar: Frequency-II
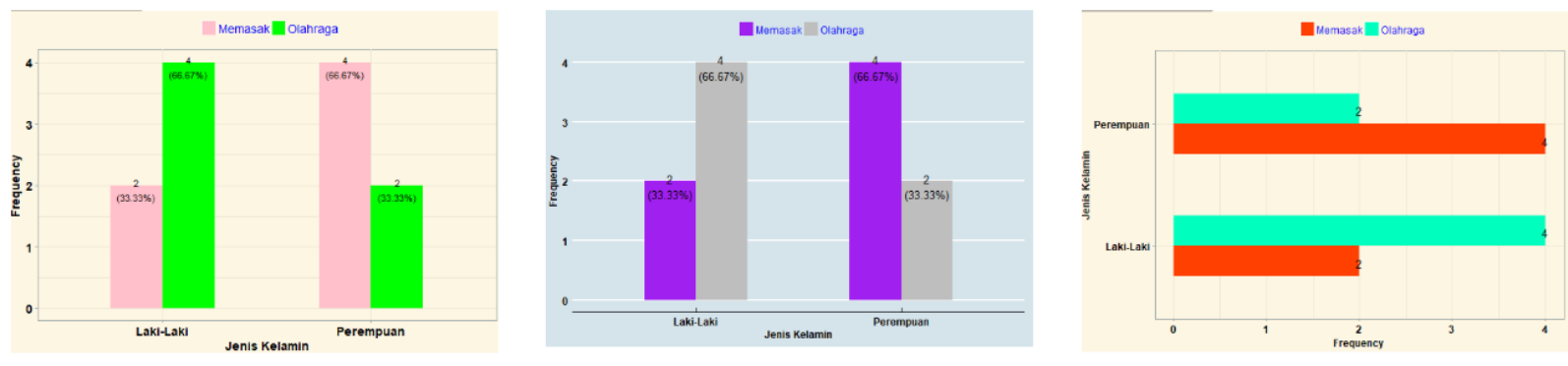
Misalkan diberikan data jenis kelamin dan hobi dari 12 responden (Tabel 1.1).

Tabel 1.1 Data Hobi dari 11 Responden (Data Fiktif)

\begin{tabular}{|c|c|c|}
\hline Nama & Jenis Kelamin & Hobi \\
\hline Ugi & 1 & 1 \\
\hline Egi & 1 & 1 \\
\hline Andi & 1 & 2 \\
\hline Budi & 1 & 2 \\
\hline Tono & 1 & 2 \\
\hline Toni & 1 & 2 \\
\hline Fitri & 2 & 2 \\
\hline Intan & 2 & 2 \\
\hline Sari & 2 & 1 \\
\hline Riri & 2 & 1 \\
\hline Rina & 2 & 1 \\
\hline Wati & 2 & 1 \\
\hline
\end{tabular}

\begin{tabular}{|c|c|c|}
\hline Angka & Jenis Kelamin & Hobi \\
\hline 1 & Laki-Laki & Memasak \\
\hline 2 & Perempuan & Olahraga \\
\hline
\end{tabular}

Berdasarkan data pada Tabel 1.1, diketahui responden yang bernama Ugi dengan jenis kelamin laki-laki, memiliki hobi memasak, responden yang bernama Andi dengan jenis kelamin laki-laki, memiliki hobi olahraga, dan seterusnya. Dari data pada Tabel 1.1, disajikan grafik batang frekuensi seperti pada Gambar 1.1. 


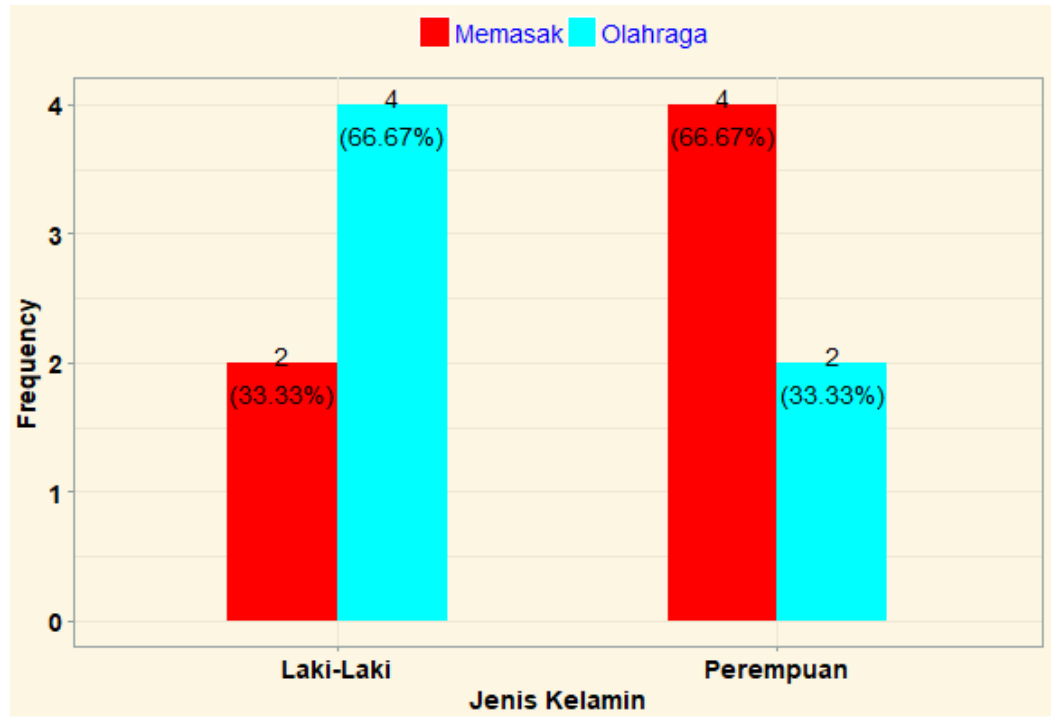

Gambar 1.1 Grafik Batang Frekuensi

Berdasarkan grafik batang frekuensi pada Gambar 1.1, diketahui:

$\Rightarrow$ Jumlah responden laki-laki dengan hobi memasak sebanyak $2(33,33 \%)$ responden, sementara jumlah responden laki-laki dengan hobi olahraga sebanyak 4 (66,67\%) responden.

$\Rightarrow$ Jumlah responden perempuan dengan hobi memasak sebanyak 4 (66,67\%) responden, sementara jumlah responden perempuan dengan hobi olahraga sebanyak $2(33,33 \%)$ responden.

Untuk membuat grafik batang frekuensi pada Gambar 1.1, kita akan menggunakan menu Bar: Frequency-I I(Gambar 1.2). 


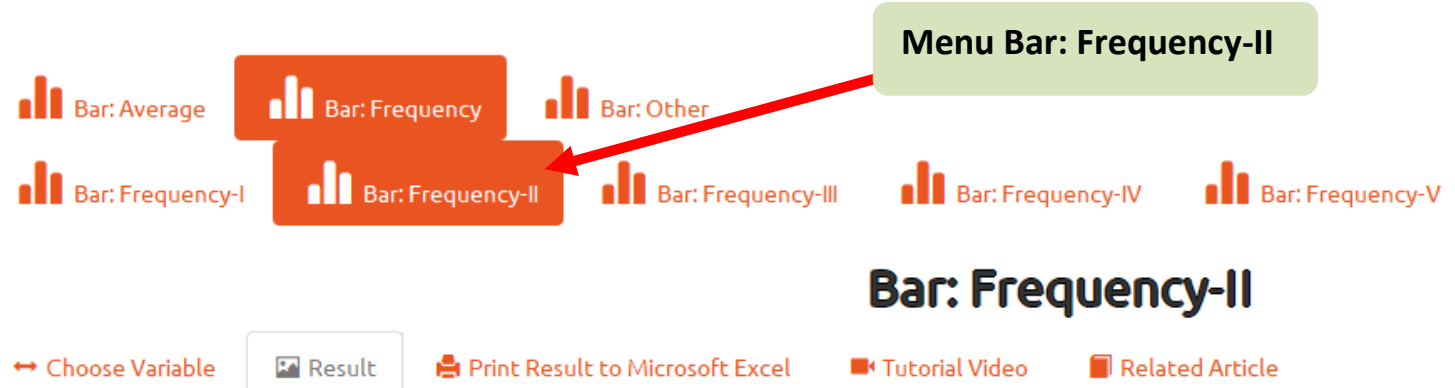

\section{Gambar 1.2 Menu Bar: Frequency-II}

Langkah pertama adalah input data pada Tabel 1.1 ke dalam STATCAL seperti pada Gambar 1.3. Perhatikan bahwa data diinput pada bagian Input Categorical Data. Selanjutnya kita akan mengakses menu Bar: Frequency-II dengan memilih Graph $=>$ Bar $=>$ Bar: Frequency $=>$ Bar: Frequency-II (Gambar 1.4).

\section{N STATCAL 四 How to Input Data in STATCAL? 四 Input Numeric Data v 四 Input Categorical Data v}

Input Categorical Data

\section{Categorical Data}

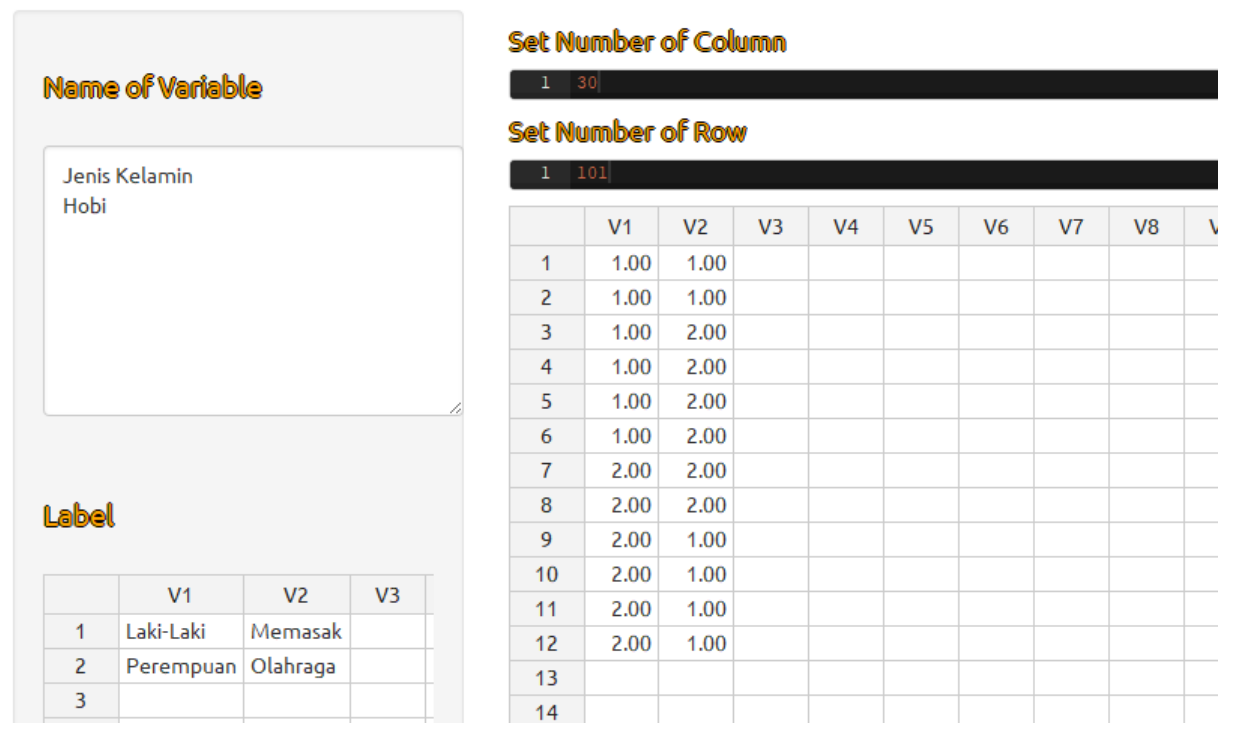

Gambar 1.3 Input Data Kategori pada Bagian Input Categorical Data 


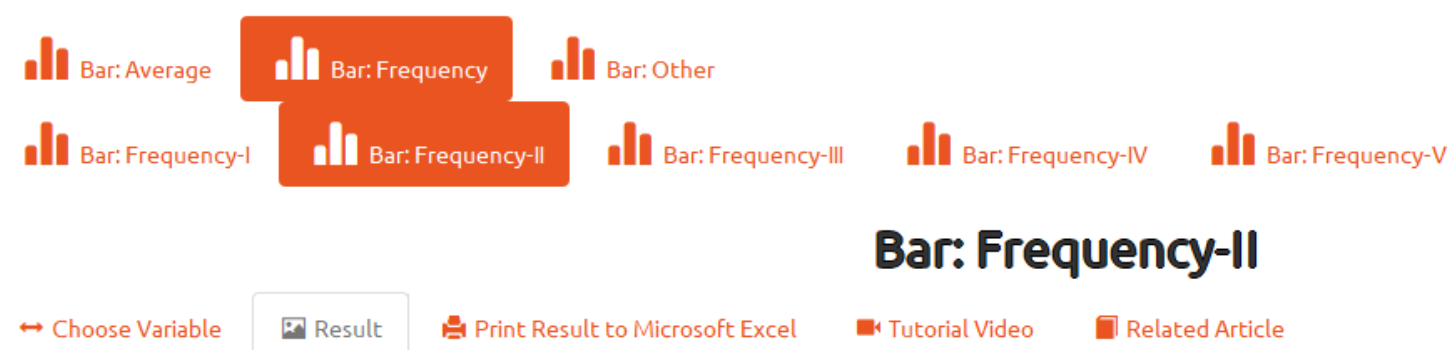

Gambar 1.4 Menu Bar: Frequency-II

Pada Gambar 1.5, pindahkan variabel jenis kelamin dan hobi ke kotak sebelah kanan.

\section{Bar: Frequency-II}

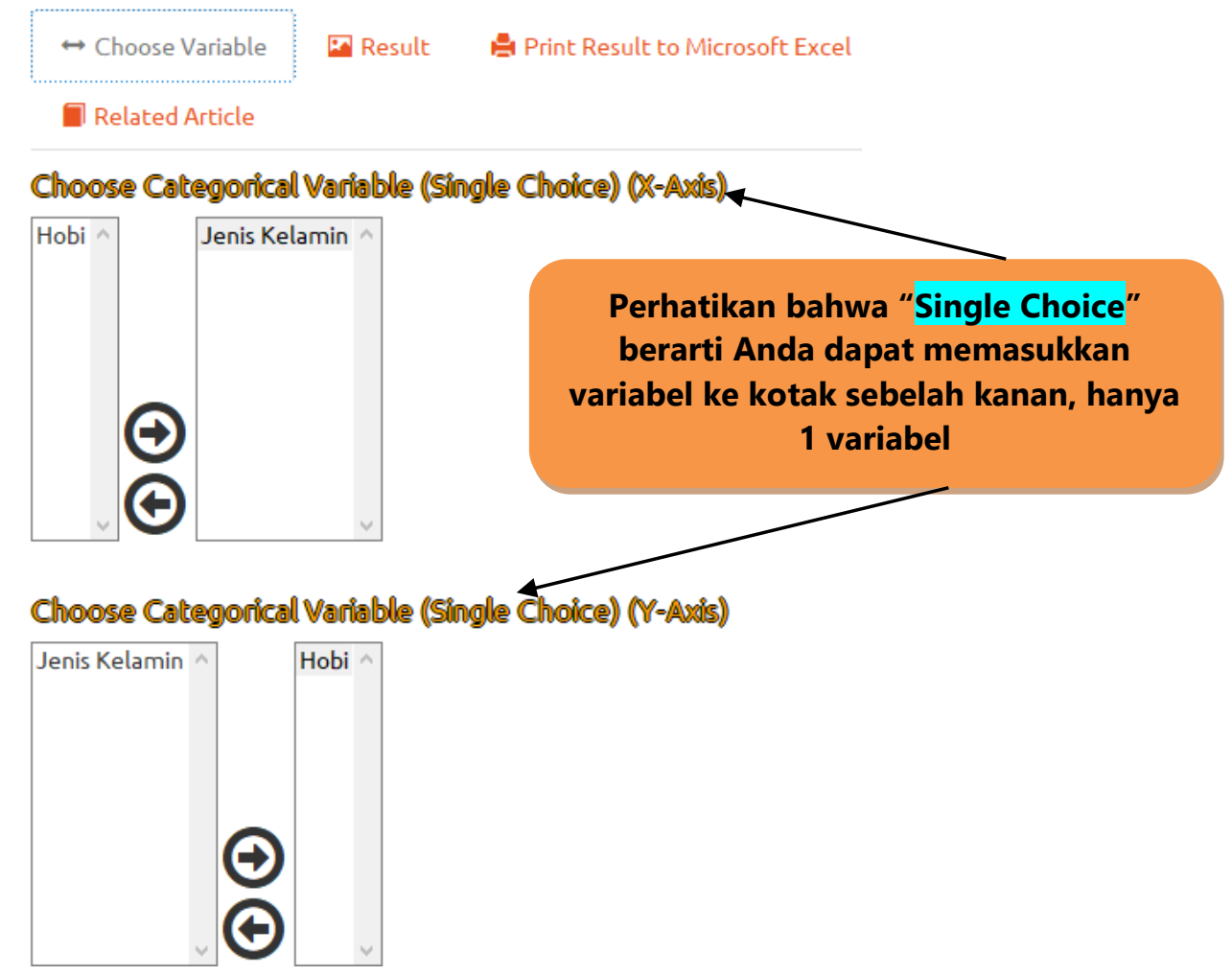

Gambar 1.5 Pemilihan Variabel 
Gambar 1.6 merupakan keterangan beberapa menu pada Bar: Frequency-II.

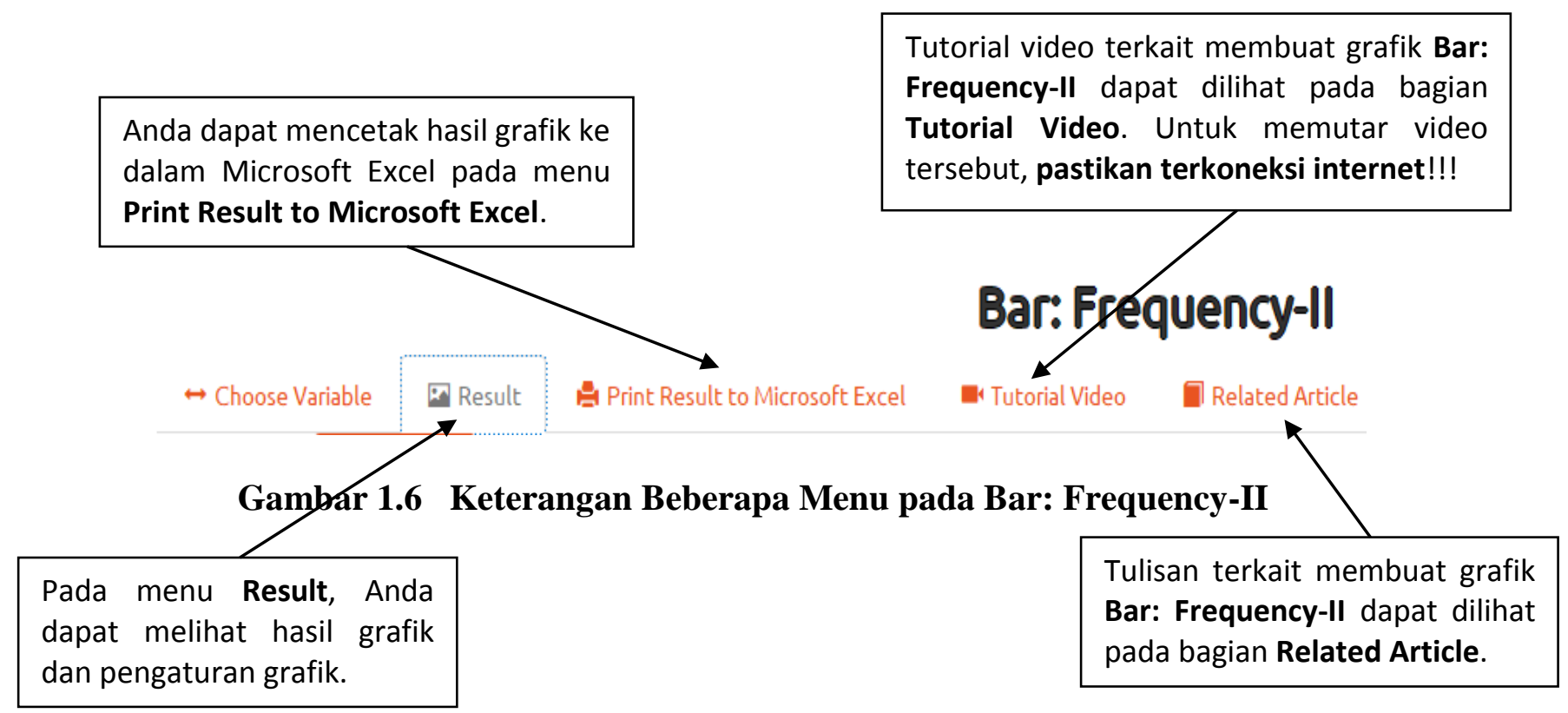

Gambar 1.7 disajikan grafik batang frekuensi.

\section{Bar: Frequency-II}

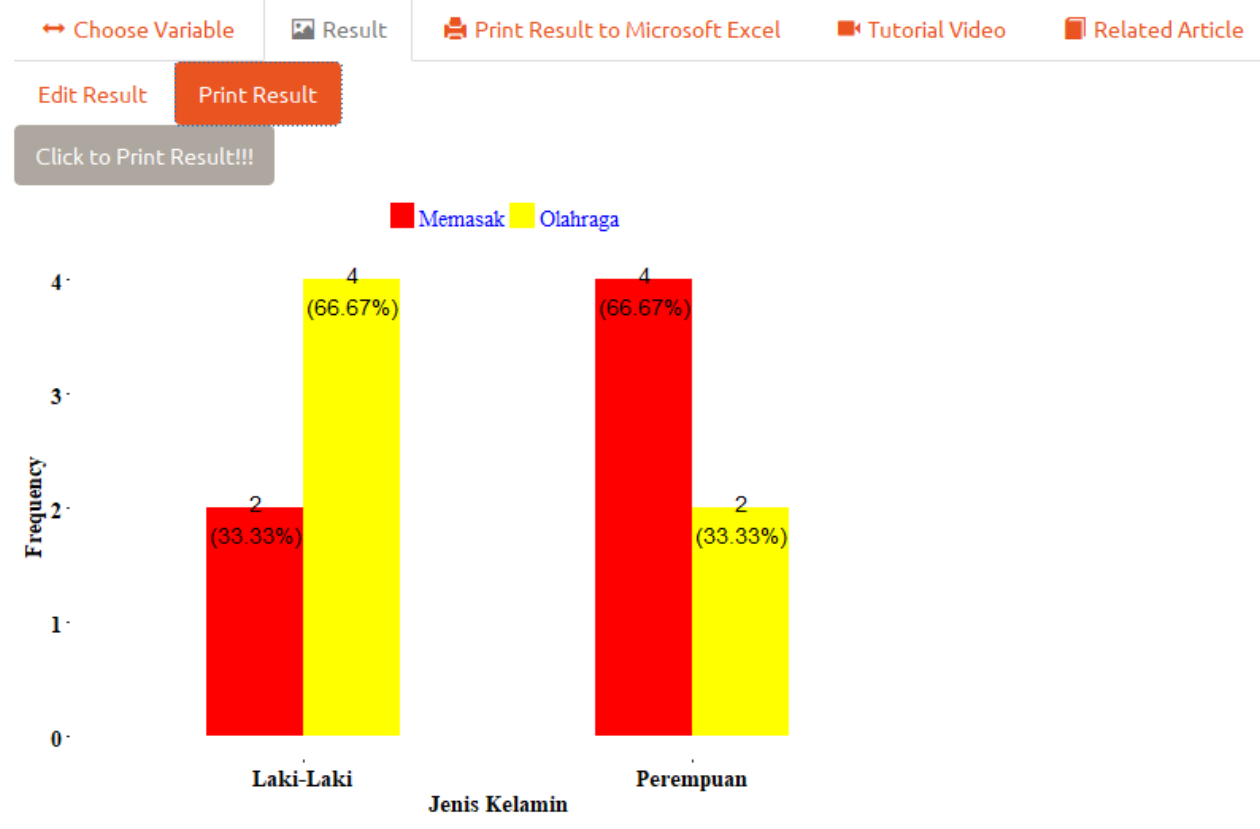

Gambar 1.7 Grafik Batang Frekuensi 


\section{Mengolah Data dengan}

Program Aplikasi Statistika

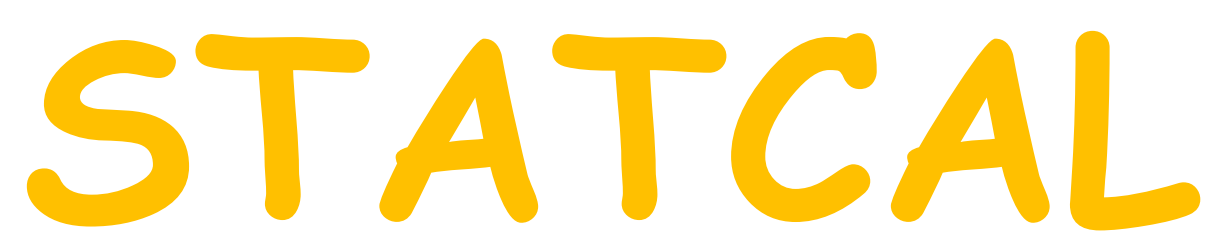

Membuat Grafik Batang Frekuensi dengan Menu

Bar: Other-I (Skala Likert)

\section{Oleh Prana Ugiana Gio}

Founder \& CEO STATCAL

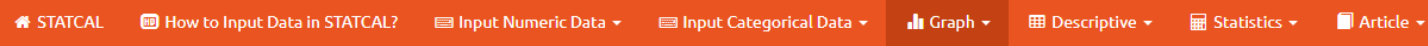

\section{Ill Bar: Average $\quad$ ill Bar: Frequency $\mathbf{d i}$ Bar: Other}

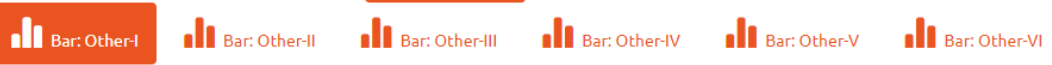

Bar: Other-1
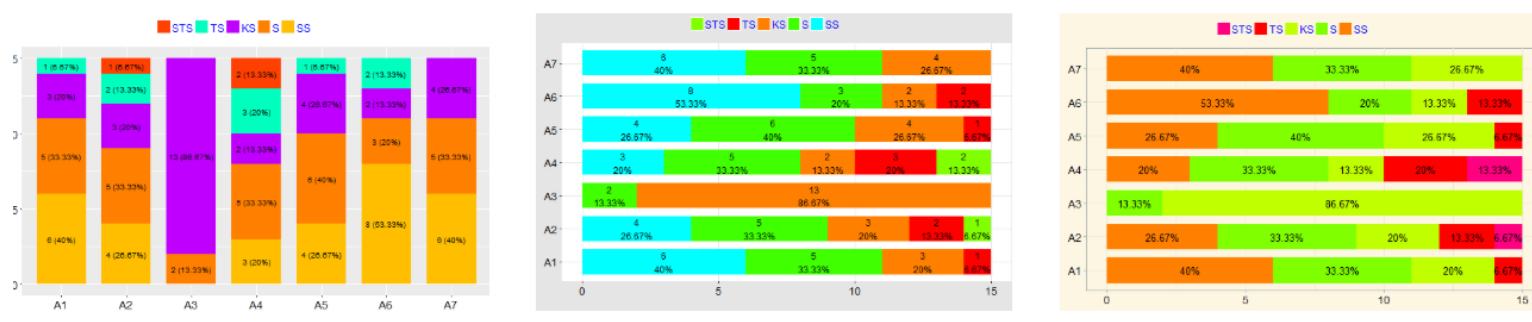
Misalkan diberikan data jawaban 10 responden untuk 6 pertanyaan (Tabel 1.1).

Tabel 1.1 Data Hobi dari 11 Responden (Data Fiktif)

\begin{tabular}{|c|c|c|c|c|c|c|}
\hline Responden & P1 & P2 & P3 & P4 & P5 & P6 \\
\hline 1 & 4 & 3 & 4 & 5 & 4 & 3 \\
\hline 2 & 5 & 2 & 4 & 5 & 4 & 3 \\
\hline 3 & 3 & 1 & 4 & 5 & 4 & 4 \\
\hline 4 & 1 & 1 & 3 & 5 & 4 & 4 \\
\hline 5 & 2 & 4 & 4 & 5 & 4 & 4 \\
\hline 6 & 3 & 4 & 4 & 5 & 4 & 4 \\
\hline 7 & 4 & 2 & 5 & 5 & 4 & 4 \\
\hline 8 & 1 & 3 & 2 & 5 & 4 & 3 \\
\hline 9 & 3 & 3 & 3 & 5 & 4 & 3 \\
\hline 10 & 4 & 4 & 4 & 5 & 4 & 3 \\
\hline
\end{tabular}

\begin{tabular}{|c|c|}
\hline Angka & Label \\
\hline 1 & STS \\
\hline 2 & TS \\
\hline 3 & KS \\
\hline 4 & S \\
\hline 5 & SS \\
\hline
\end{tabular}

Berdasarkan data pada Tabel 1.1, diketahui responden pertama (responden ke-1), menjawab setuju (S) pada pertanyaan pertama, kurang setuju (KS) pada pertanyaan kedua, dan seterusnya. Responden keempat (responden ke-4), menjawab sangat tidak setuju (STS) pada pertanyaan pertama, sangat tidak setuju (STS) pada pertanyaan kedua, dan seterusnya. Dari data pada Tabel 1.1, disajikan grafik batang frekuensi seperti pada Gambar 1.1. 


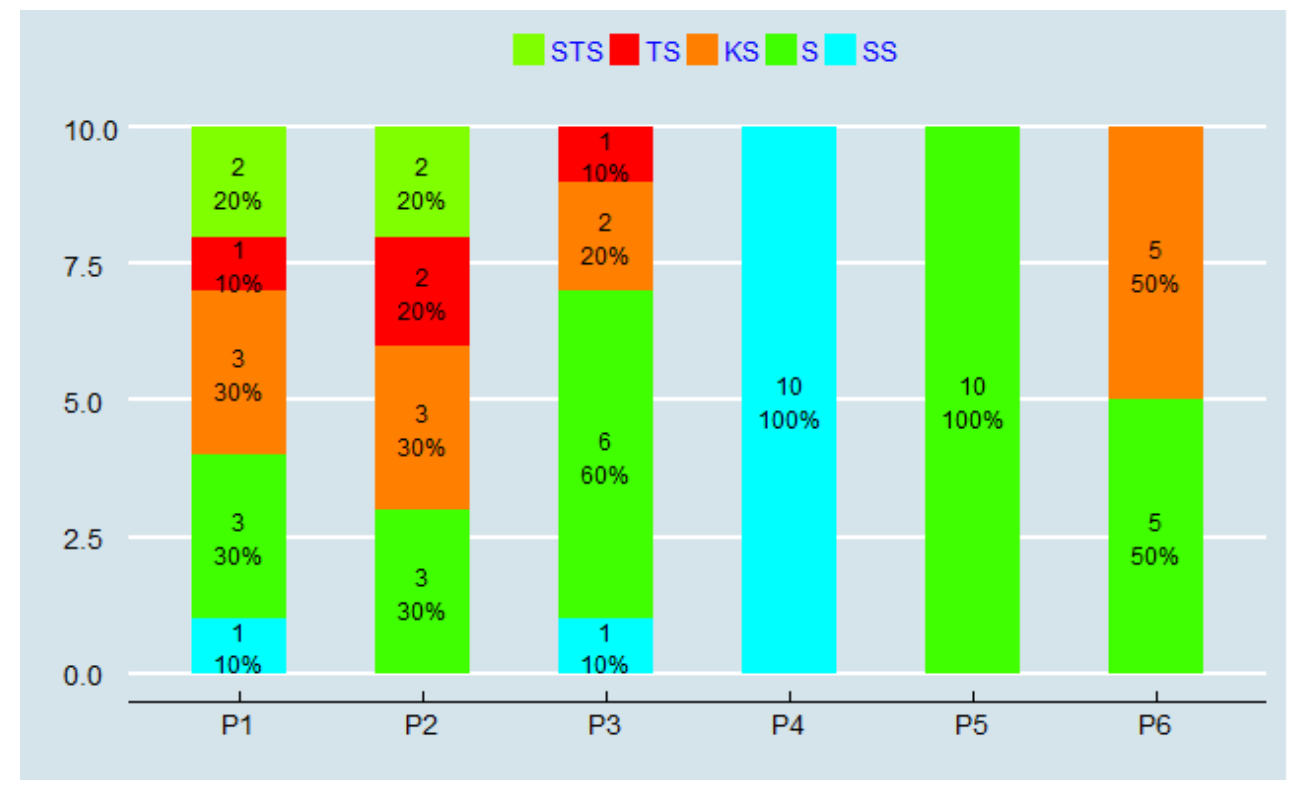

Gambar 1.1 Grafik Batang Frekuensi

Berdasarkan grafik batang frekuensi pada Gambar 1.1, diketahui:

$\Rightarrow$ Untuk pertanyaan pertama (P1), sebanyak $2(20 \%)$ responden menjawab sangat tidak setuju (STS), 1 (10\%) responden menjawab tidak setuju (TS), 3 (30\%) responden menjawab kurang setuju, dan seterusnya.

Untuk membuat grafik batang frekuensi pada Gambar 1.1, kita akan menggunakan menu Bar: Other-I (Gambar 1.2).

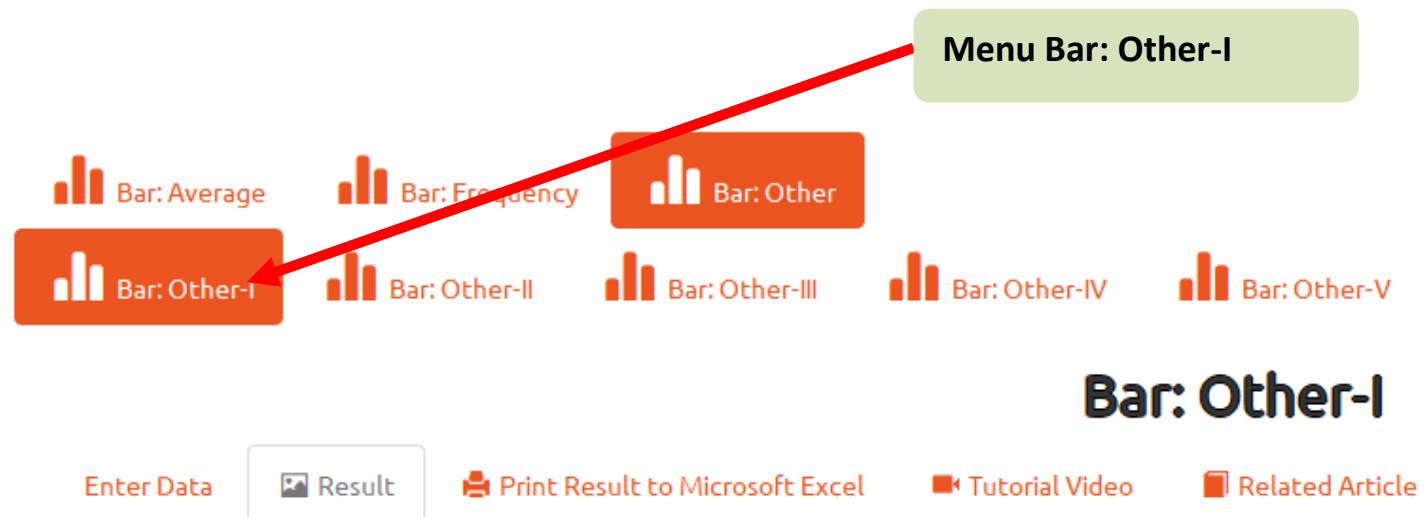

Gambar 1.2 Menu Bar: Other-I 
Untuk mengakses menu Bar: Other-I, pilih Graph => Bar => Bar: Other => Bar: Other-I (Gambar 1.3).

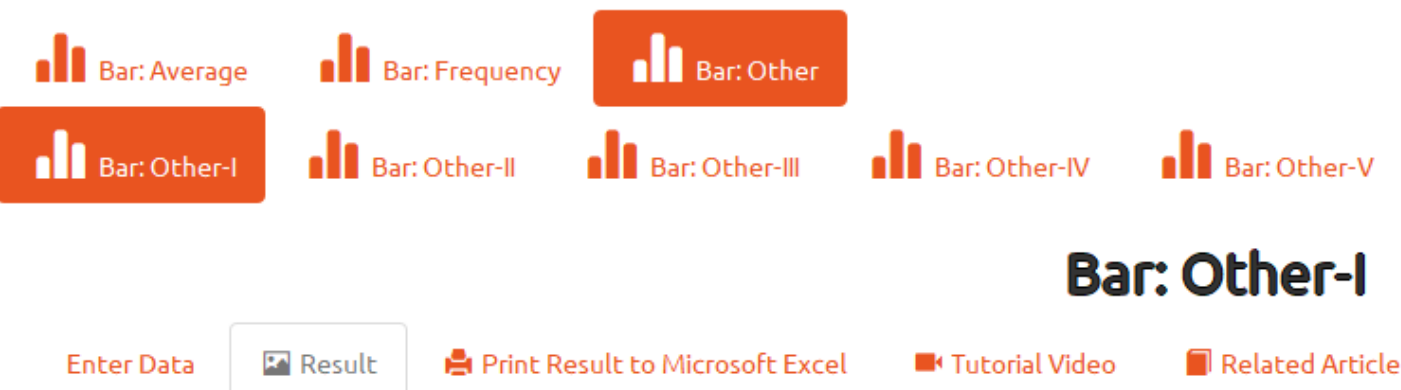

Gambar 1.3 Menu Bar: Other-I

Dengan menggunakan data pada Tabel 1.1, input data seperti pada Gambar 1.4.

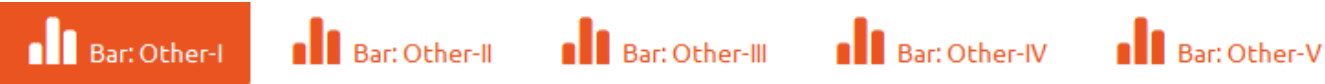

\section{Bar: Other-I}

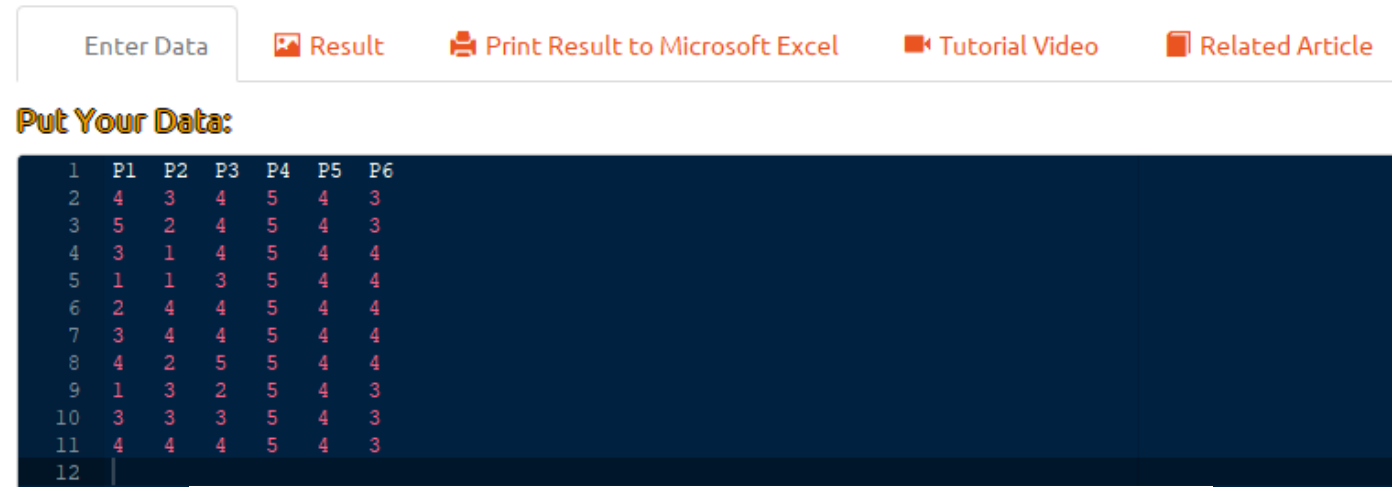

/alue and Label:

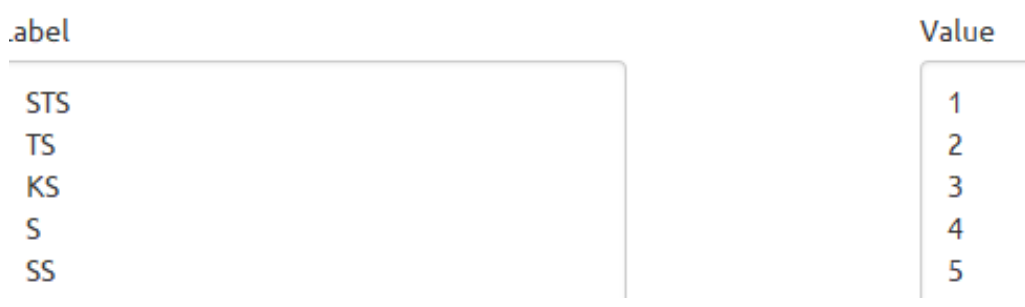

Gambar 1.4 Input Data pada Bar: Other-I 
Hasil dari grafik batang frekuensi dapat dilihat pada bagian Result (Gambar 1.5).

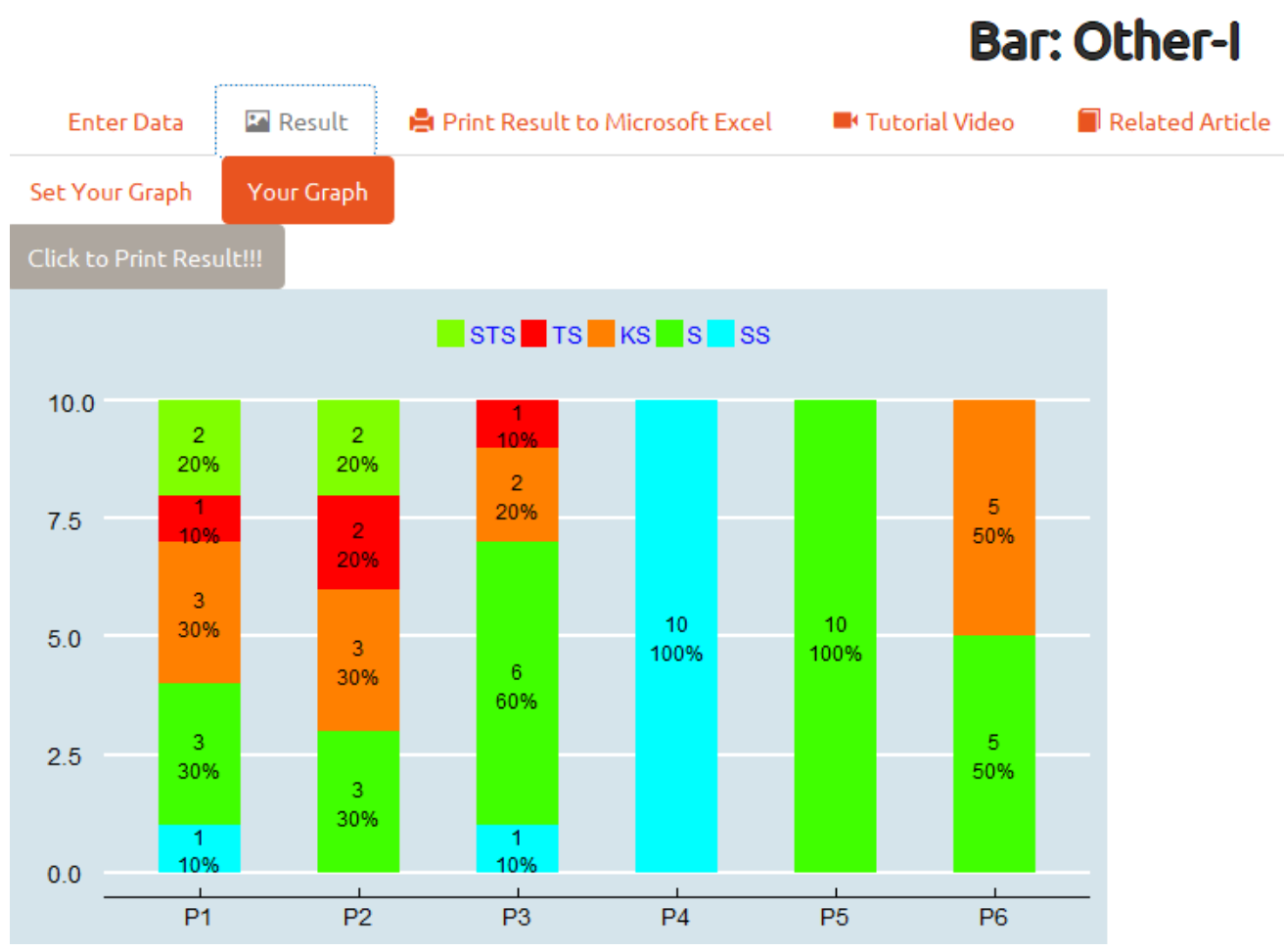

Gambar 1.5 Grafik Batang Frekuensi

Hasil dari grafik batang frekuensi juga dapat dicetak ke dalam Microsoft Excel dengan menggunakan menu Print Result to Microsoft Excel. 


\section{Mengolah Data dengan}

Program Aplikasi Statistika
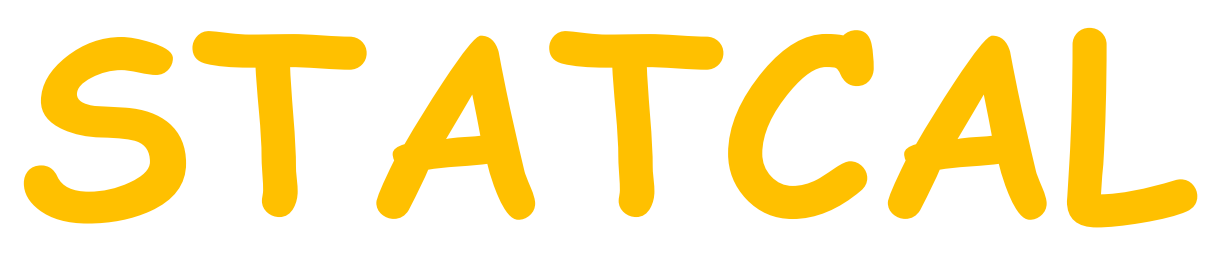

Membuat Grafik Batang Frekuensi dengan Menu<smiles>CCCOC(=[Ga])Br</smiles>

\section{Oleh Prana Ugiana Gio}

Founder \& CEO STATCAL

Created by Prana Ugiana Gio \& Rezzy Eko Caraka

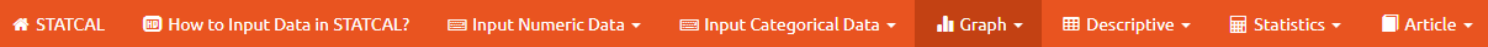

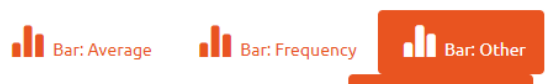

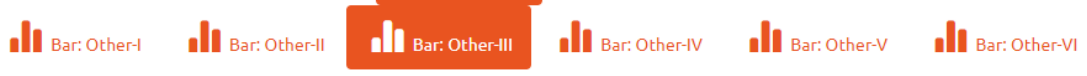

Bar: Other-III
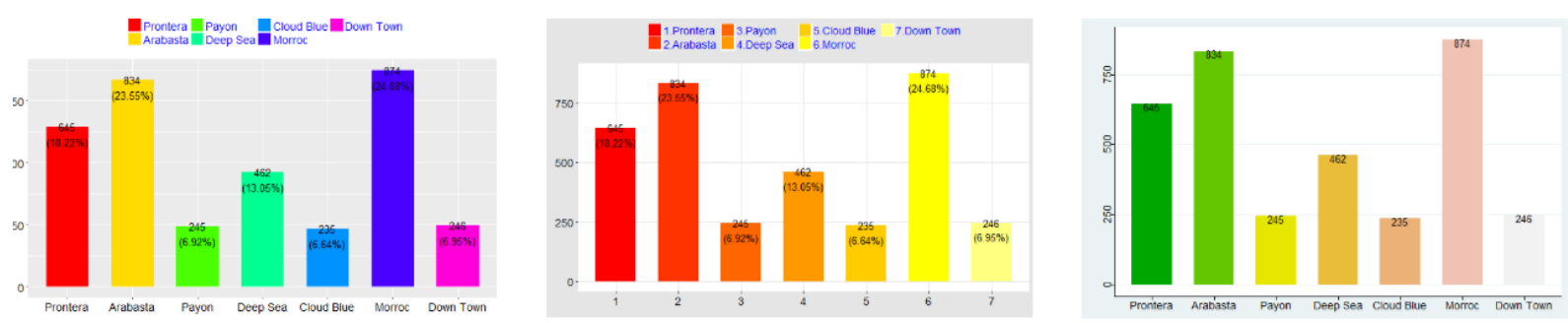
Misalkan diberikan data jumlah penduduk berdasarkan 7 kecamatan (Tabel 1.1).

Tabel 1.1 Data Hobi dari 11 Responden (Data Fiktif)

\begin{tabular}{|c|c|c|}
\hline Kecamatan & Jumlah Penduduk & Persentase \\
\hline Prontera & 645 & $18.22 \%$ \\
\hline Arabasta & 834 & $23.55 \%$ \\
\hline Payon & 245 & $6.92 \%$ \\
\hline Deep Sea & 462 & $13.05 \%$ \\
\hline Cloud Blue & 235 & $6.64 \%$ \\
\hline Morroc & 874 & $24.68 \%$ \\
\hline Down Town & 246 & $6.95 \%$ \\
\hline Total & 3541 & $100 \%$ \\
\hline
\end{tabular}

Berdasarkan data pada Tabel 1.1, diketahui jumlah penduduk pada kecamatan Prontera sebanyak $645(18,22 \%)$, jumlah penduduk pada kecamatan Arabasta sebanyak 834 (23,55\%), dan seterusnya. Dari data pada Tabel 1.1, disajikan grafik batang frekuensi seperti pada Gambar 1.1.

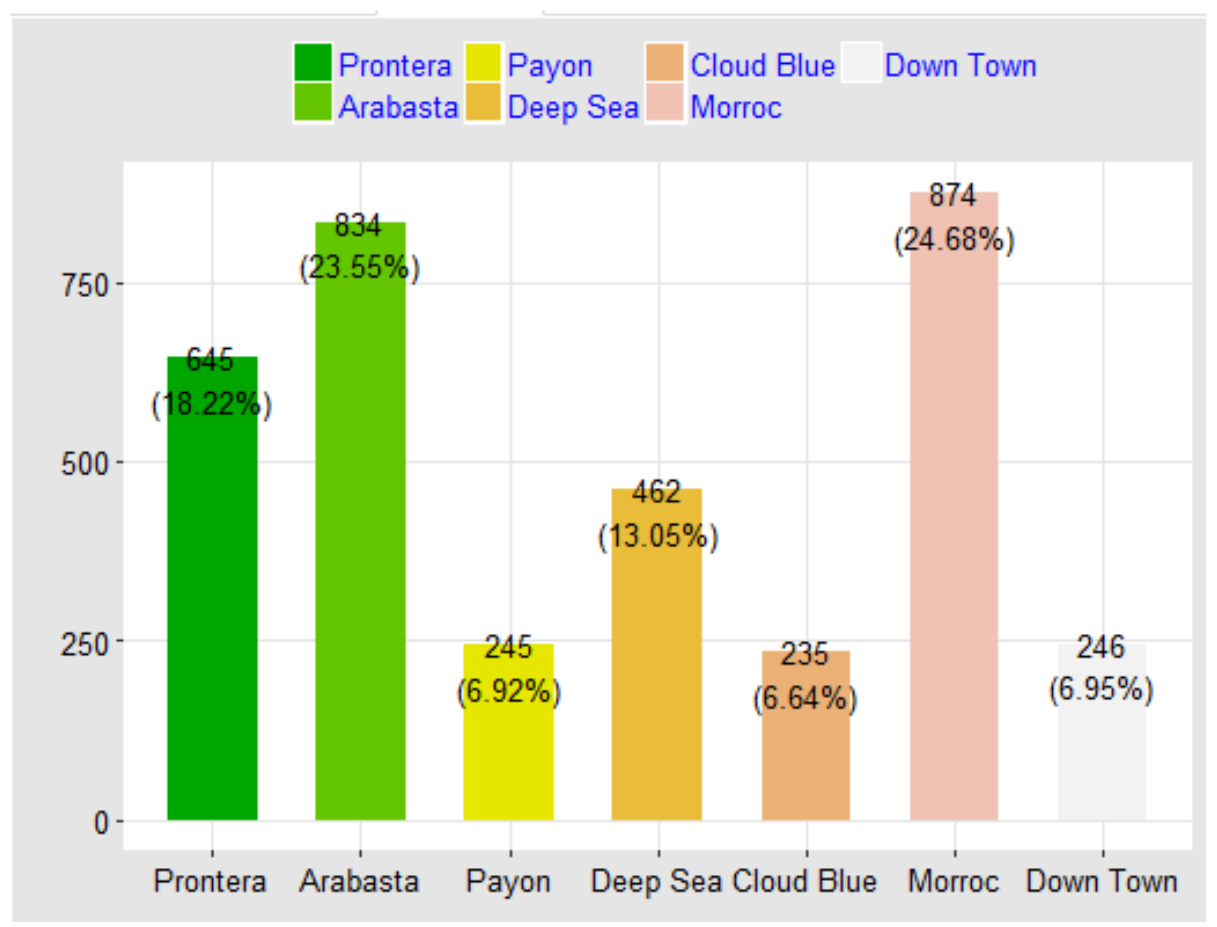

Gambar 1.1 Grafik Batang Frekuensi 
Berdasarkan grafik batang frekuensi pada Gambar 1.1, diketahui jumlah penduduk pada kecamatan Prontera sebanyak 645 (18,22\%), jumlah penduduk pada kecamatan Arabasta sebanyak $834(23,55 \%)$, dan seterusnya. Untuk membuat grafik batang frekuensi pada Gambar 1.1, kita akan menggunakan menu Bar: Other-III (Gambar 1.2).

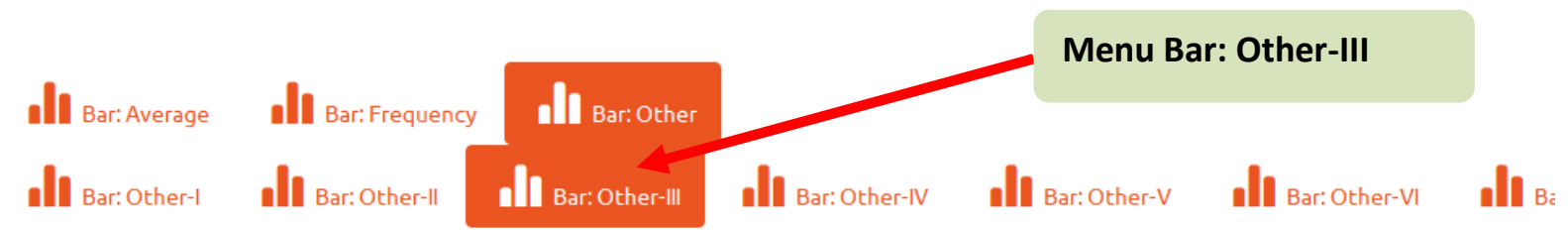

\section{Bar: Other-III}

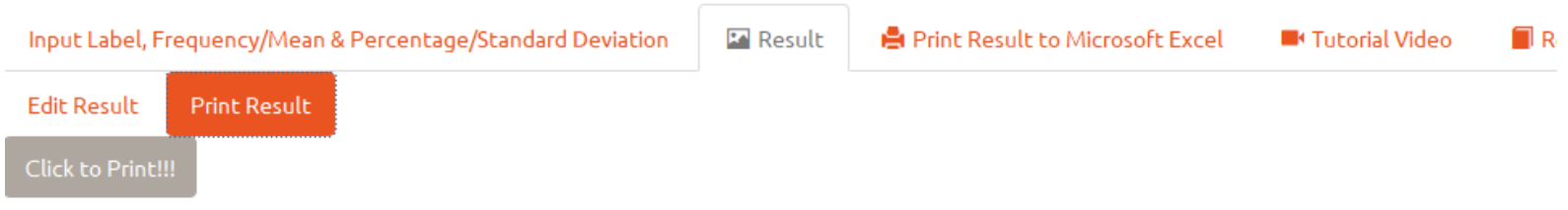

\section{Gambar 1.2 Menu Bar: Other-III}

Untuk mengakses menu Bar: Other-III, pilih Graph => Bar => Bar: Other => Bar: Other-

III (Gambar 1.2). Dengan menggunakan data pada Tabel 1.1, input data seperti pada Gambar

1.3 .

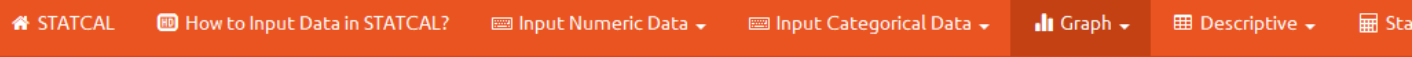

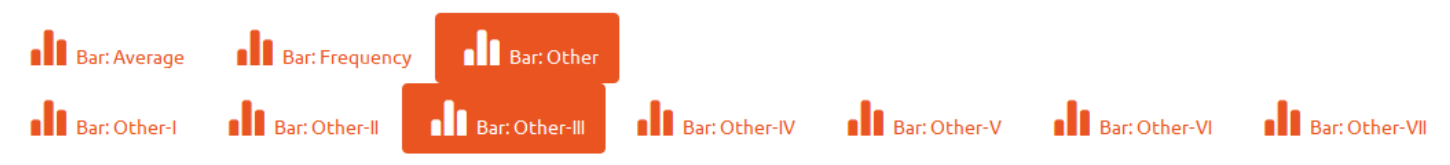

\section{Bar: Other-III}

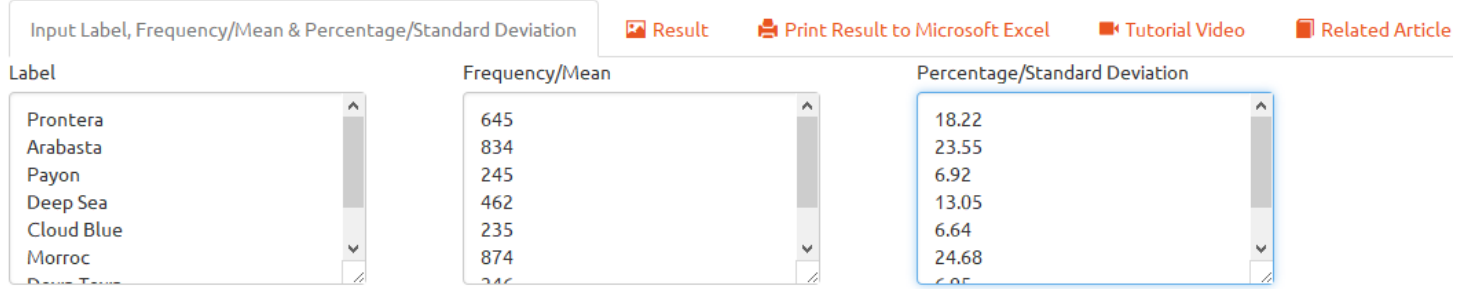

Gambar 1.3 Input Data pada Bar: Other-III 
Hasil dari grafik batang frekuensi dapat dilihat pada bagian Result $=>$ Print Result (Gambar 1.4).

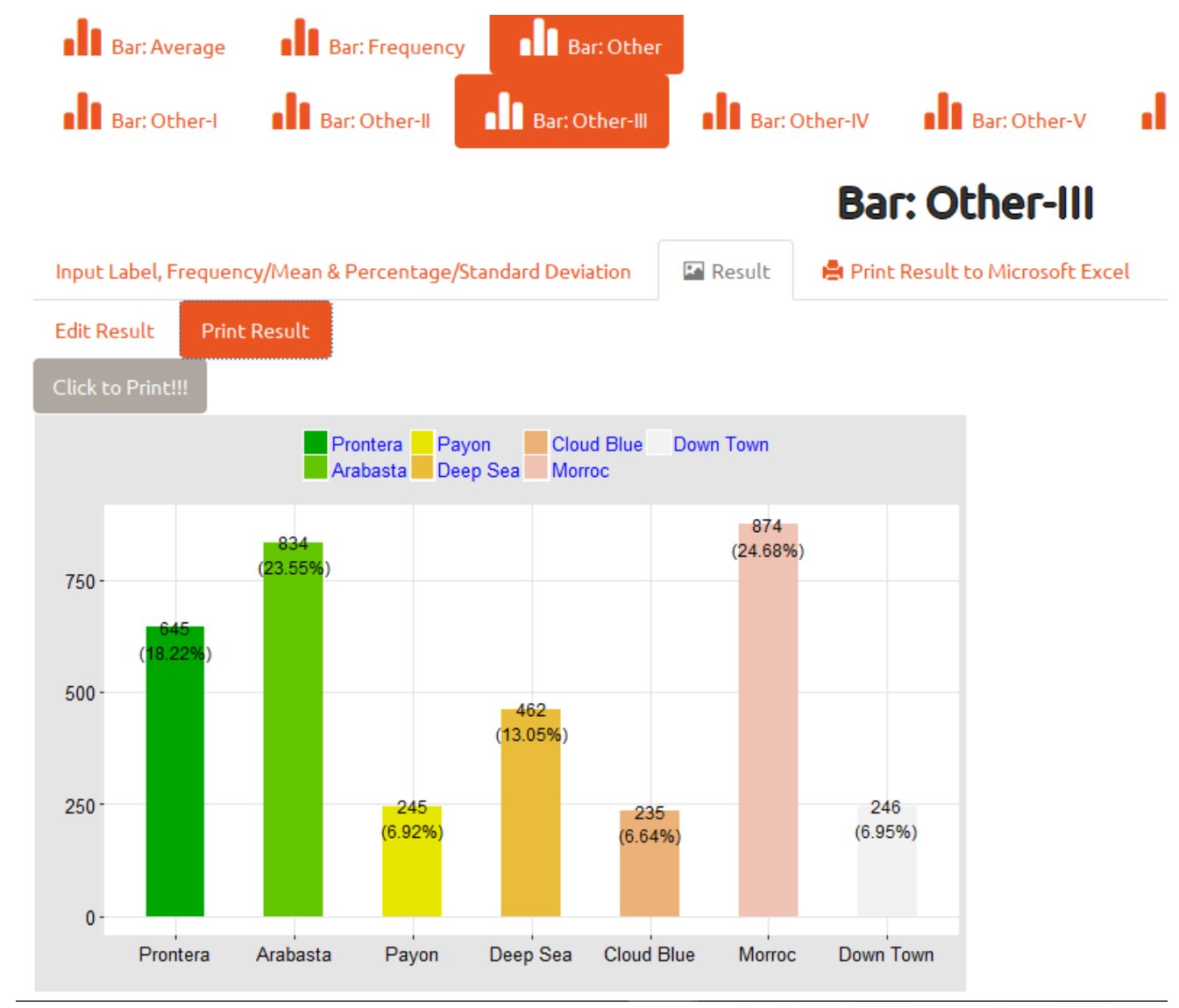

Gambar 1.4 Grafik Batang Frekuensi

Hasil dari grafik batang frekuensi juga dapat dicetak ke dalam Microsoft Excel dengan menggunakan menu Print Result to Microsoft Excel. 


\section{Mengolah Data dengan}

Program Aplikasi Statistika

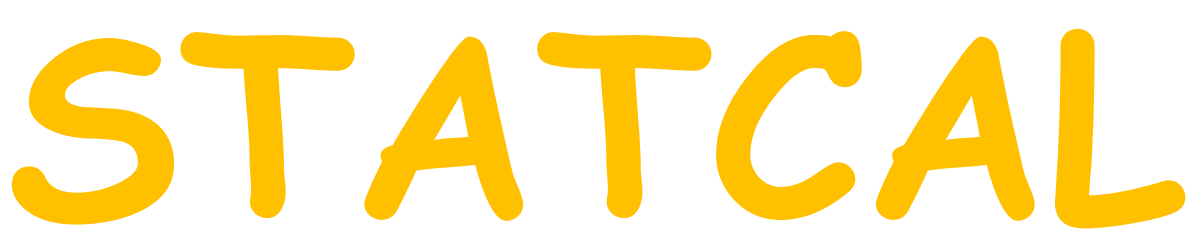

Membuat Grafik Batang Rata-Rata dengan Menu Bar: Other-III

\section{Oleh Prana Ugiana Gio}

\section{Founder \& CEO STATCAL}

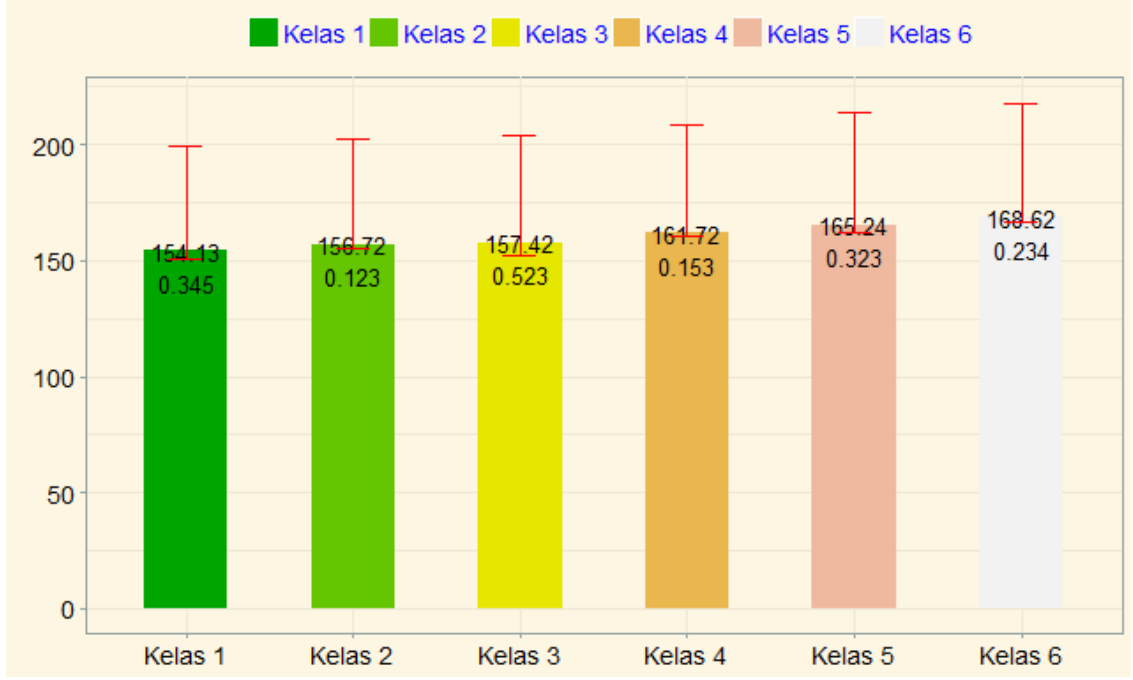


Misalkan diberikan data rata-rata tinggi badan siswa, mulai dari kelas 1 sampai dengan kelas 6 (Tabel 1.1).

Tabel 1.1 Data Tinggi Badan berdasarkan Kelas 1 s/d Kelas 6 (Data Fiktif)

\begin{tabular}{|c|c|c|}
\hline Kelas & Rata-Rata Tinggi Badan & Standar Deviasi Tinggi Badan \\
\hline Kelas 1 & 154.13 & 0.345 \\
\hline Kelas 2 & 156.72 & 0.123 \\
\hline Kelas 3 & 157.42 & 0.523 \\
\hline Kelas 4 & 161.72 & 0.153 \\
\hline Kelas 5 & 165.24 & 0.323 \\
\hline Kelas 6 & 168.62 & 0.234 \\
\hline
\end{tabular}

Berdasarkan data pada Tabel 1.1, diketahui rata-rata tinggi badan siswa kelas 1 adalah 154,13 $\mathrm{cm}$, dengan standar deviasi 0,345. Rata-rata tinggi badan siswa kela 2 adalah 156,72 cm, dengan standar deviasi 0,123, dan seterusnya. Dari data pada Tabel 1.1, disajikan grafik batang rata-rata seperti pada Gambar 1.1.

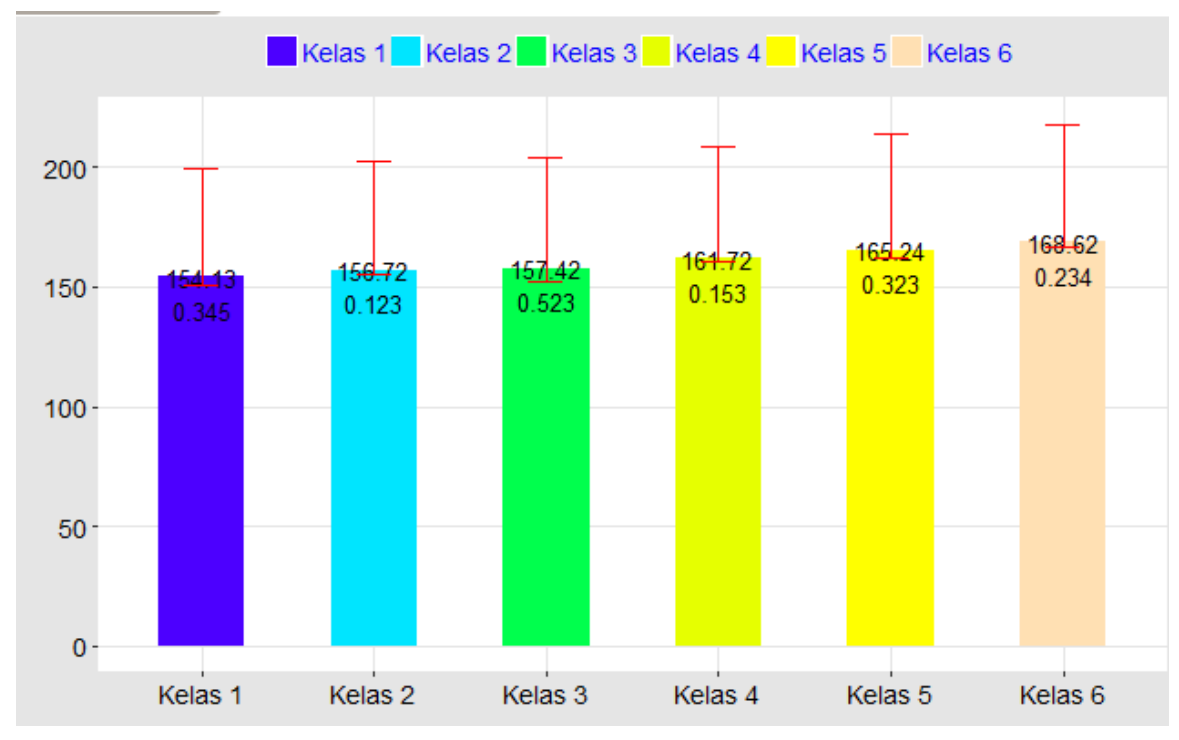

Gambar 1.1 Grafik Batang Rata-Rata 
Berdasarkan grafik batang rata-rata pada Gambar 1.1, diketahui rata-rata tinggi badan siswa kelas 1 adalah 154,13 cm, dengan standar deviasi 0,345. Rata-rata tinggi badan siswa kela 2 adalah 156,72 cm, dengan standar deviasi 0,123, dan seterusnya. Untuk membuat grafik batang rata-rata pada Gambar 1.1, kita akan menggunakan menu Bar: Other-III (Gambar 1.2).

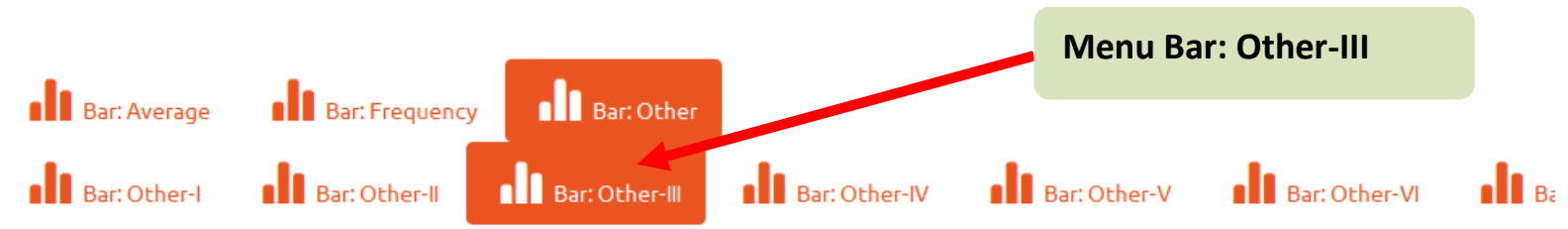

\section{Bar: Other-III}

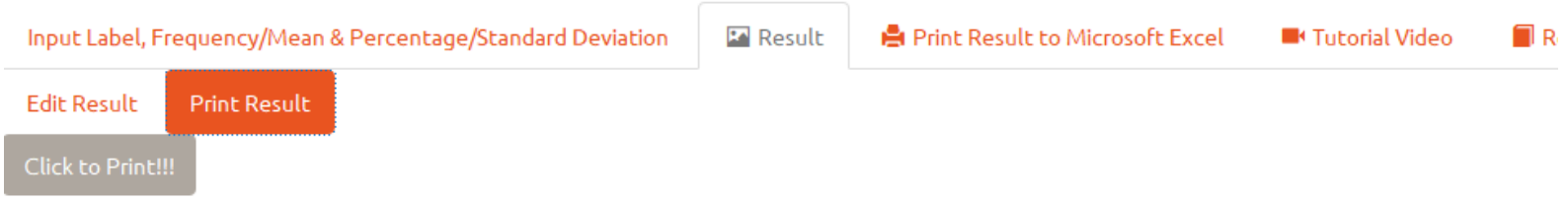

\section{Gambar 1.2 Menu Bar: Other-III}

Untuk mengakses menu Bar: Other-III, pilih Graph => Bar => Bar: Other => Bar: Other-

III (Gambar 1.2). Dengan menggunakan data pada Tabel 1.1, input data seperti pada Gambar

1.3 .

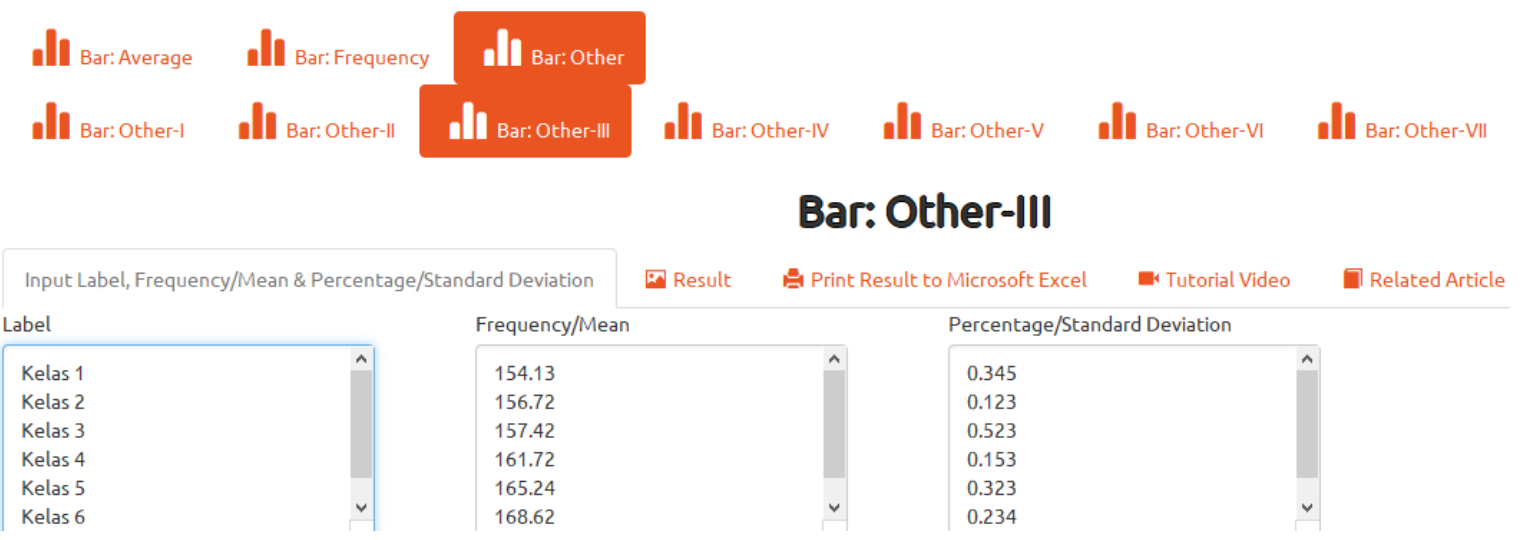

Gambar 1.3 Input Data pada Bar: Other-III 
Hasil dari grafik batang rata-rata dapat dilihat pada bagian Result $=>$ Print Result (Gambar $1.4)$.

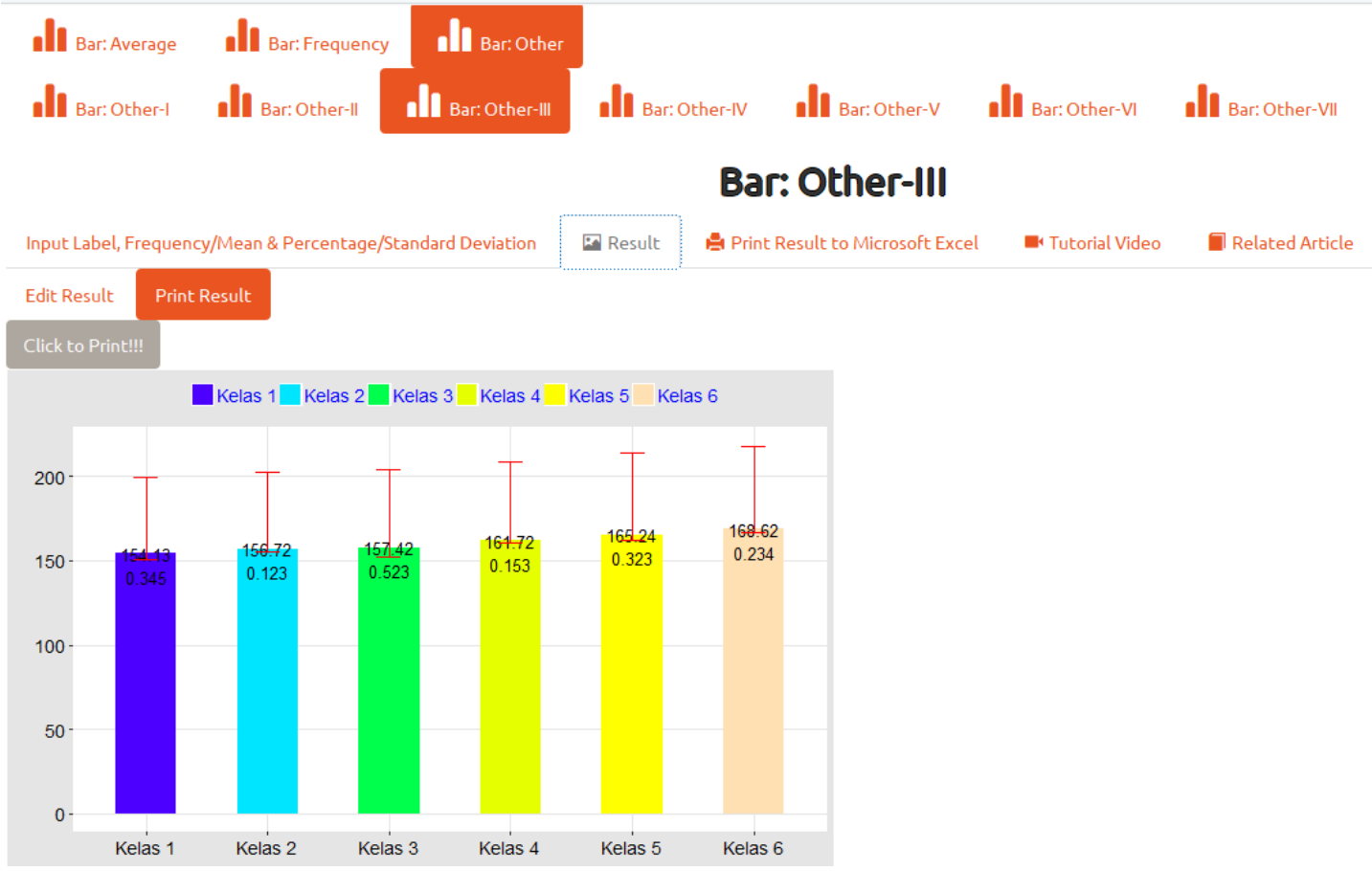

Gambar 1.4 Grafik Batang Rata-Rata

Hasil dari grafik batang rata-rata juga dapat dicetak ke dalam Microsoft Excel dengan menggunakan menu Print Result to Microsoft Excel. 


\section{Mengolah Data dengan}

Program Aplikasi Statistika

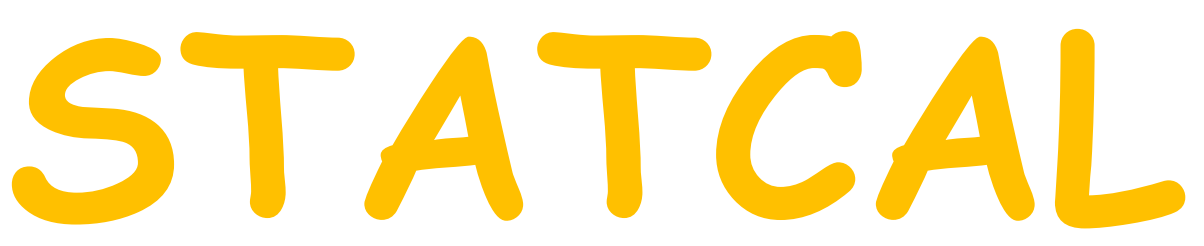

Membuat Grafik Batang Frekuensi dengan Menu Bar: Other-IV

\section{Oleh Prana Ugiana Gio}

Founder \& CEO STATCAL

Created by Prana Ugiana Gio \& Rezzy Eko Caraka

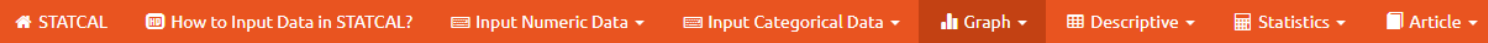

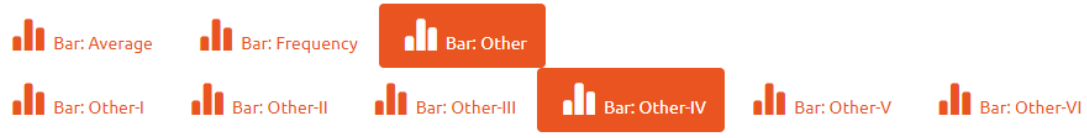

Bar: Other-IV
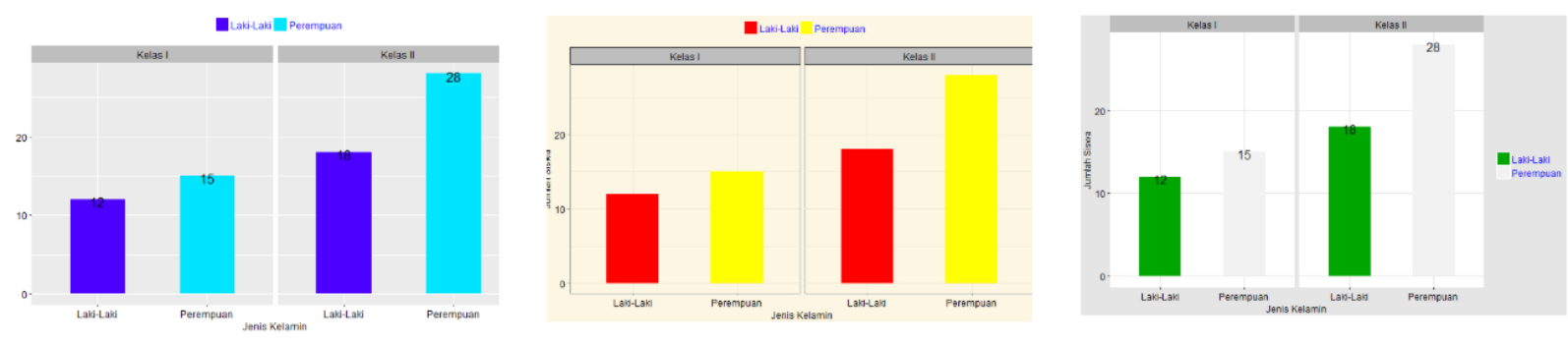
Misalkan diberikan data jumlah siswa berdasarkan kelas dan jenis kelamin (Tabel 1.1).

Tabel 1.1 Data Hobi dari 11 Responden (Data Fiktif)

\begin{tabular}{|c|c|c|}
\hline Kelas & Jenis Kelamin & Jumlah Siswa \\
\hline 1 & 1 & 12 \\
\hline 1 & 2 & 15 \\
\hline 2 & 1 & 18 \\
\hline 2 & 2 & 28 \\
\hline
\end{tabular}

\begin{tabular}{|c|c|c|}
\hline Angka & Kelas & Jenis Kelamin \\
\hline 1 & Kelas I & Laki-Laki \\
\hline 2 & Kelas II & Perempuan \\
\hline
\end{tabular}

Berdasarkan data pada Tabel 1.1, diketahui jumlah siswa kelas I laki-laki sebanyak 12, jumlah siswa kelas I perempuan sebanyak 15, dan seterusnya. Dari data pada Tabel 1.1, disajikan grafik batang frekuensi seperti pada Gambar 1.1.

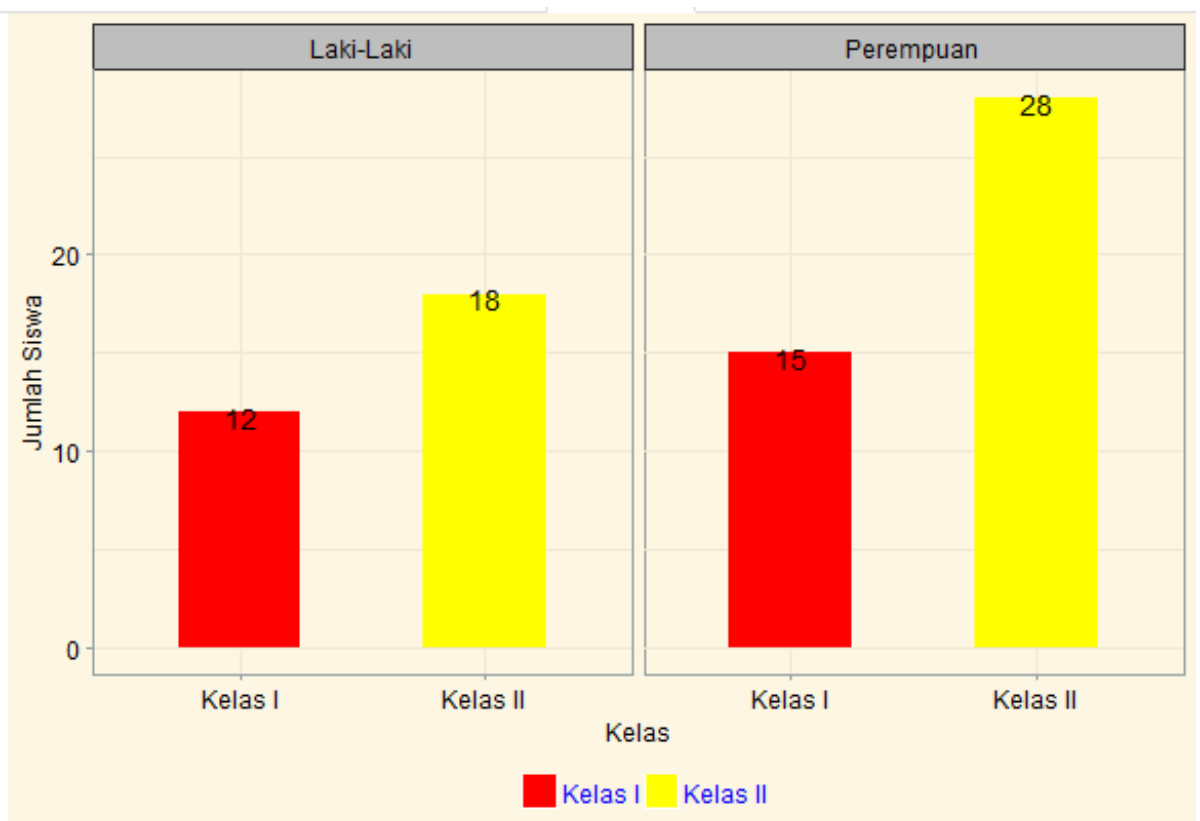

Gambar 1.1 Grafik Batang Frekuensi 
Untuk membuat grafik batang frekuensi pada Gambar 1.1, kita akan menggunakan menu Bar: Other-IV (Gambar 1.2).

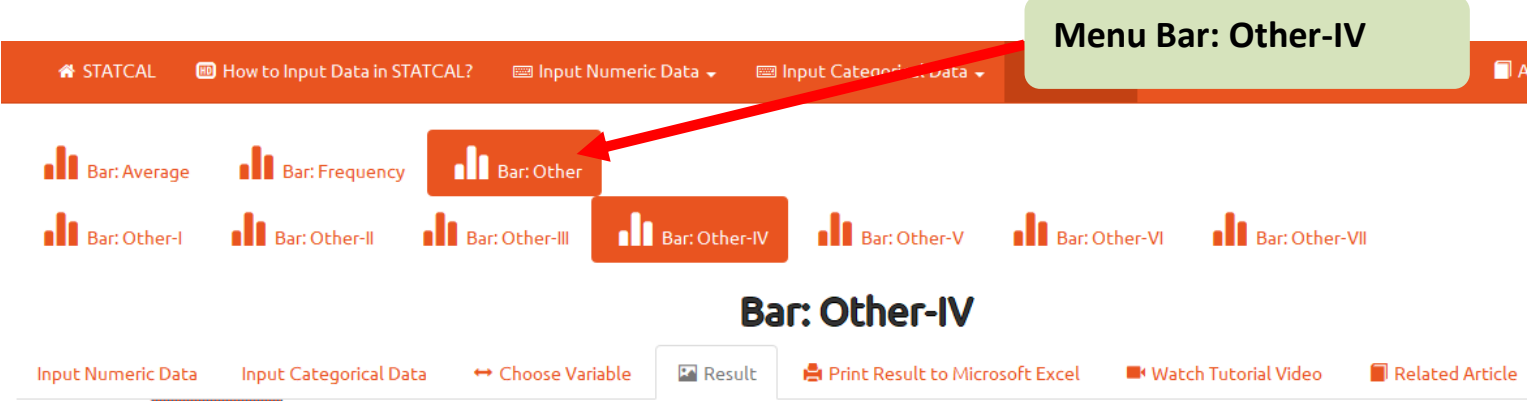

\section{Gambar 1.2 Menu Bar: Other-IV}

Untuk mengakses menu Bar: Other-IV, pilih Graph => Bar => Bar: Other => Bar: OtherIV(Gambar 1.2). Dengan menggunakan data pada Tabel 1.1, input data seperti pada Gambar 1.3 (untuk data numerik) dan Gambar 1.4 (untuk data kategori).

\begin{tabular}{|c|c|c|c|c|c|}
\hline \multirow[b]{2}{*}{ Input Numeric Data } & \multicolumn{5}{|c|}{ Bar: Other-IV } \\
\hline & Input Categorical Data & $\rightarrow$ Choose Variable & Result & A Print Result to Microsoft Excel & - Watch Tutorial Video \\
\hline
\end{tabular}

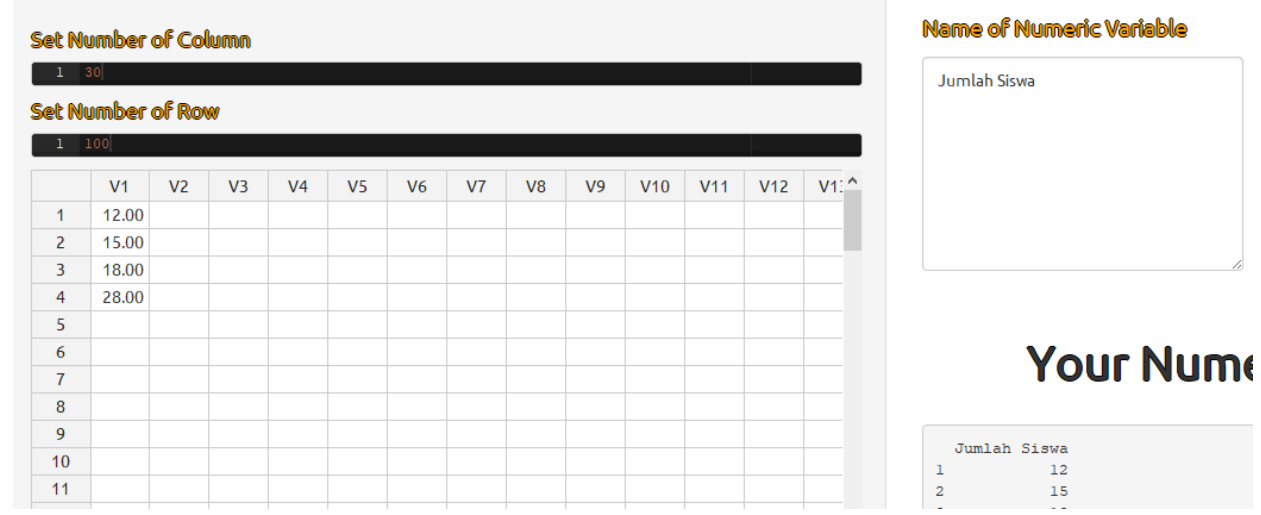

Gambar 1.3 Input Data Numerik pada Menu Bar: Other-IV 


\section{Bar: Other-IV}

\section{Input Categorical Data}
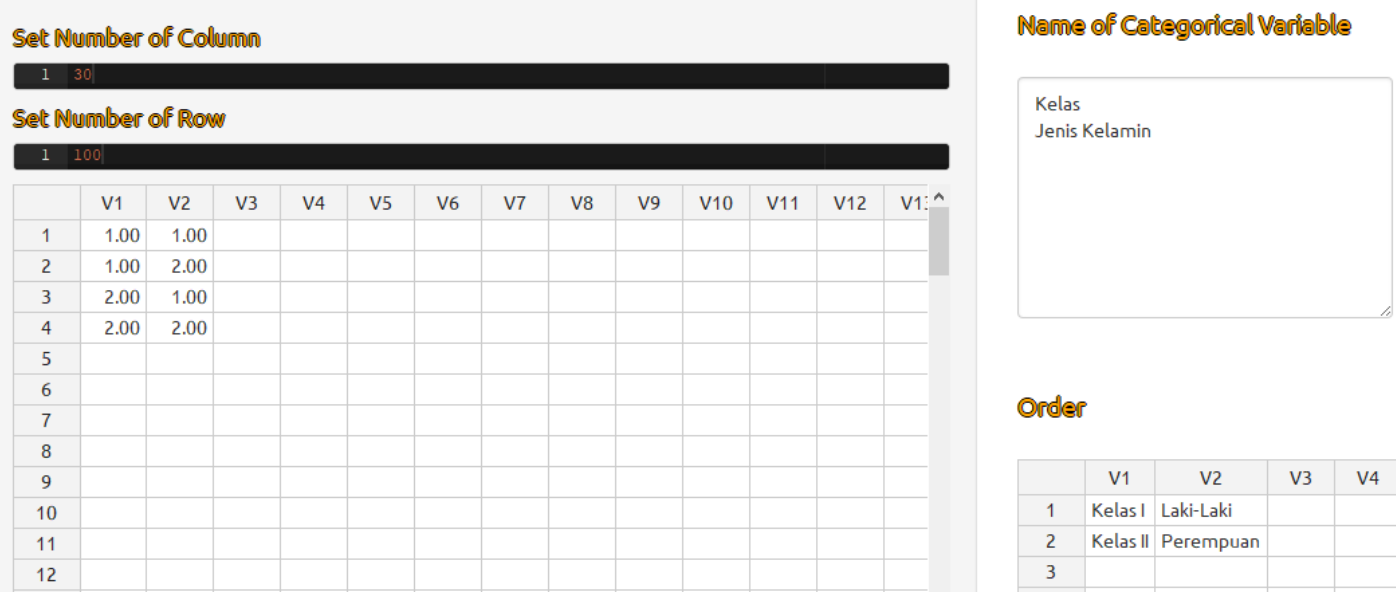

Gambar 1.4 Input Data Kategori pada Menu Bar: Other-IV

Lakukan pemilihan variabel pada bagian Choose Variable, seperti pada Gambar 1.5.

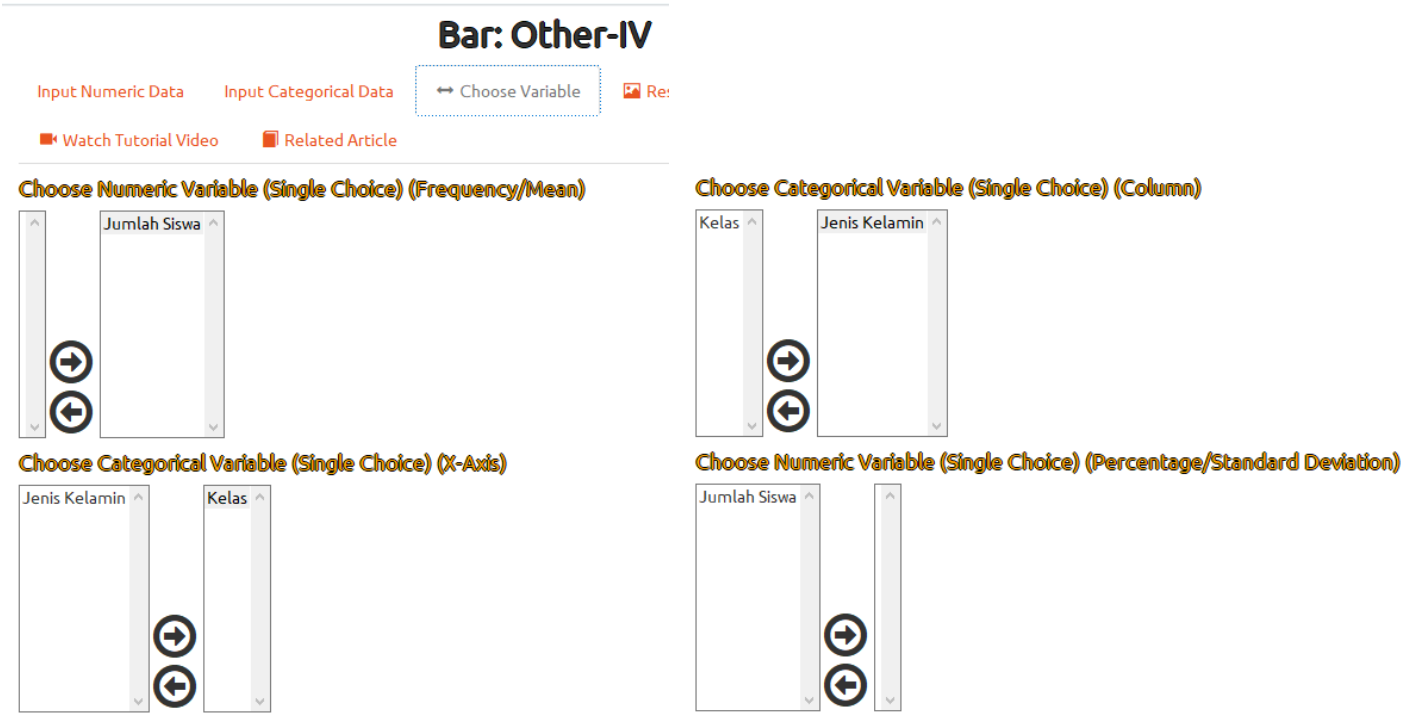

Gambar 1.5 Pemilihan Variabel 
Hasil dari grafik batang frekuensi dapat dilihat pada bagian Result $=>$ Print Result $($ Gambar 1.6)

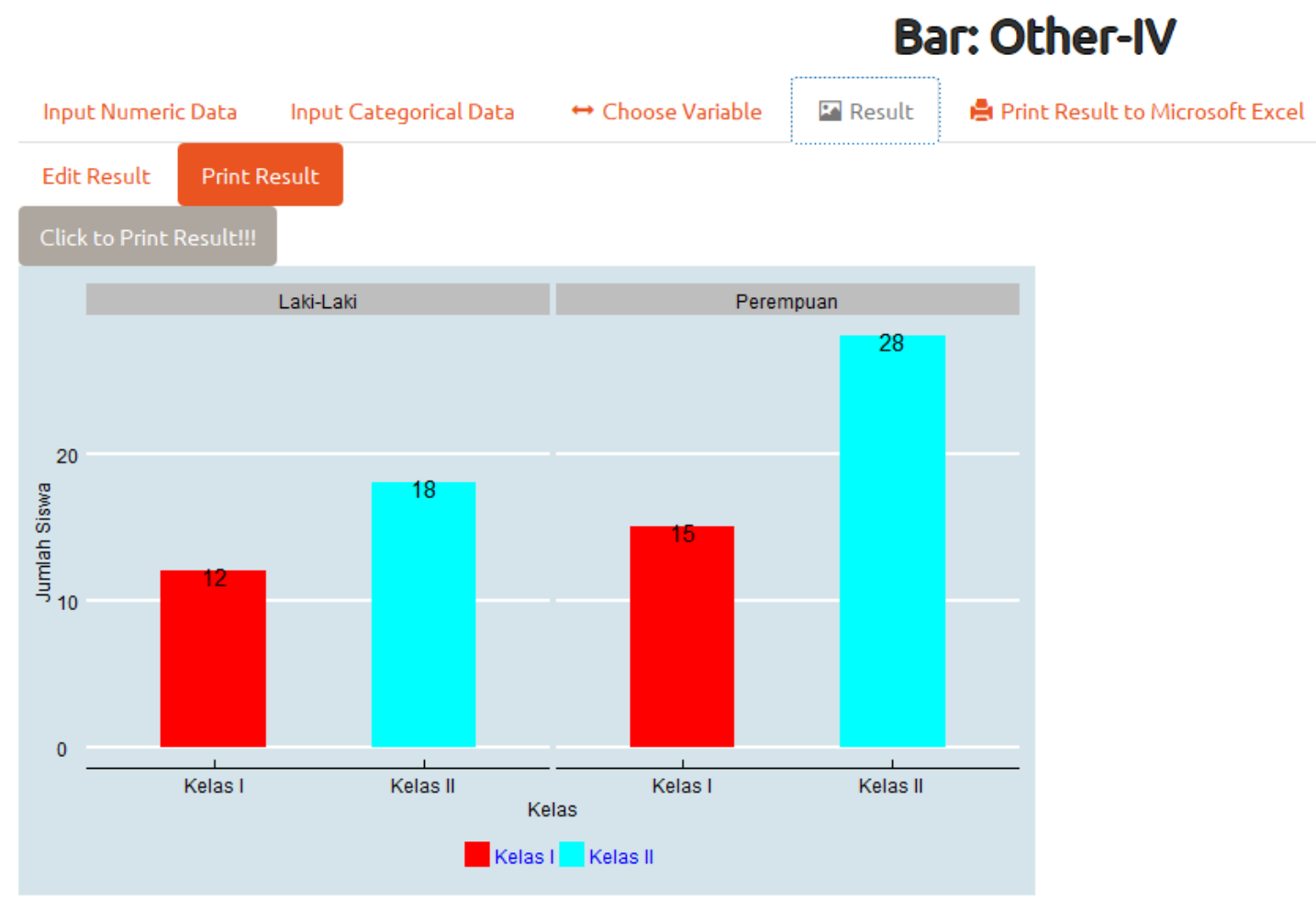

Gambar 1.6 Grafik Batang Frekuensi

Hasil dari grafik batang frekuensi juga dapat dicetak ke dalam Microsoft Excel dengan menggunakan menu Print Result to Microsoft Excel. 


\section{Mengolah Data dengan} Program Aplikasi Statistika

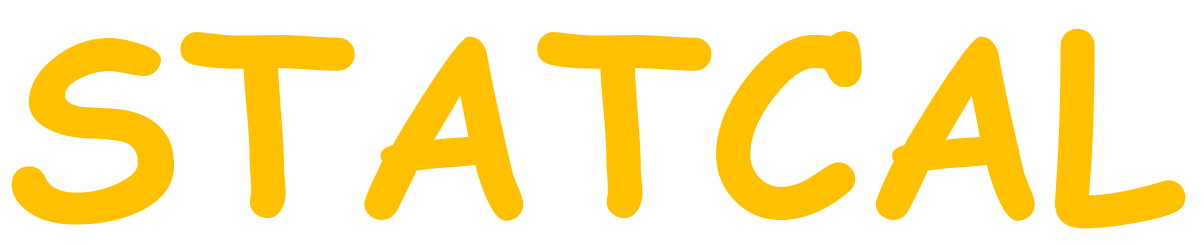

Membuat Grafik Batang Rata-Rata dengan Menu

$$
\text { Bar: Other-IV }
$$

\section{Oleh Prana Ugiana Gio}

\section{Founder \& CEO STATCAL}

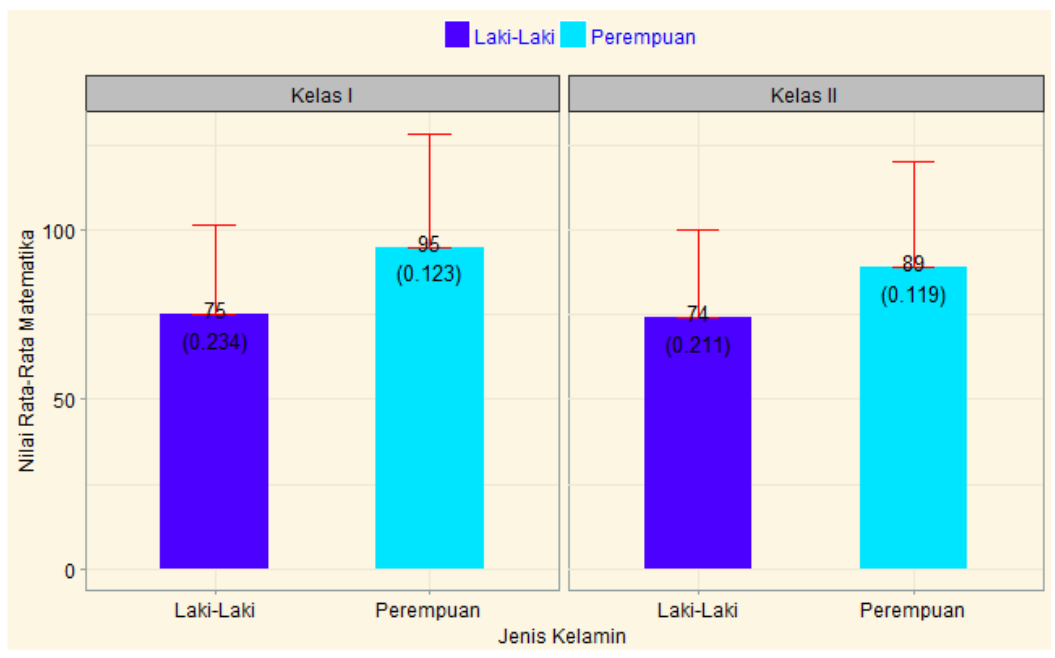


Misalkan diberikan data rata-rata nilai matematika berdasarkan kelas dan jenis kelamin (Tabel $1.1)$.

\section{Tabel 1.1 Data Rata-Rata Nilai Matematika berdasarkan Kelas dan Jenis Kelamin (Data Fiktif)}

\begin{tabular}{|c|c|c|c|}
\hline Kelas & Jenis Kelamin & Rata-Rata Nilai Matematika & Standar Deviasi \\
\hline 1 & 1 & 75 & 0.234 \\
\hline 1 & 2 & 95 & 0.123 \\
\hline 2 & 1 & 74 & 0.211 \\
\hline 2 & 2 & 89 & 0.119 \\
\hline
\end{tabular}

\begin{tabular}{|c|c|c|}
\hline Angka & Kelas & Jenis Kelamin \\
\hline 1 & Kelas I & Laki-Laki \\
\hline 2 & Kelas II & Perempuan \\
\hline
\end{tabular}

Berdasarkan data pada Tabel 1.1, diketahui rata-rata nilai matematika untuk kelas I, jenis kelamin laki-laki adalah 75, dengan standar deviasi 0,234. Rata-rata nilai matematika untuk kelas II, jenis kelamin laki-laki adalah 74, dengan standar deviasi 0,211. Dari data pada Tabel 1.1, disajikan grafik batang rata-rata seperti pada Gambar 1.1.

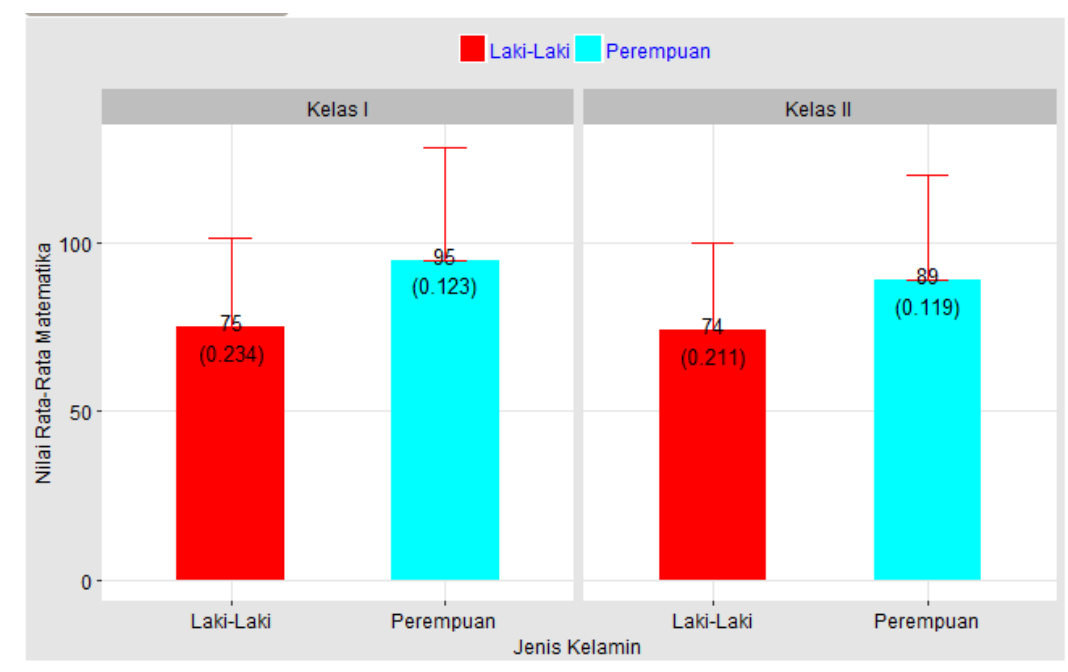

Gambar 1.1 Grafik Batang Rata-Rata 
Untuk membuat grafik batang rata-rata pada Gambar 1.1, kita akan menggunakan menu Bar: Other-IV (Gambar 1.2).

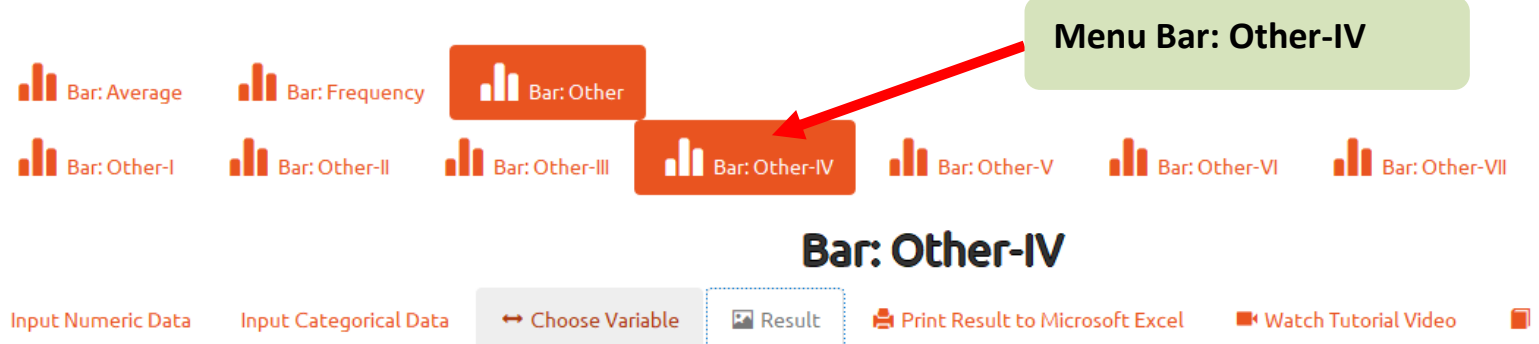

\section{Gambar 1.2 Menu Bar: Other-IV}

Untuk mengakses menu Bar: Other-IV, pilih Graph => Bar => Bar: Other => Bar: Other-IV

(Gambar 1.2). Dengan menggunakan data pada Tabel 1.1, input data seperti pada Gambar 1.3 (data numerik) dan Gambar 1.4 (data kategori).

\section{Bar: Other-IV}

Input Numeric Data Input Categorical Data $\leftrightarrow$ Choose Variable $\quad$ Result $\quad$ Print Result to Microsoft Excel Watch Tutorial Video Input Numeric Data
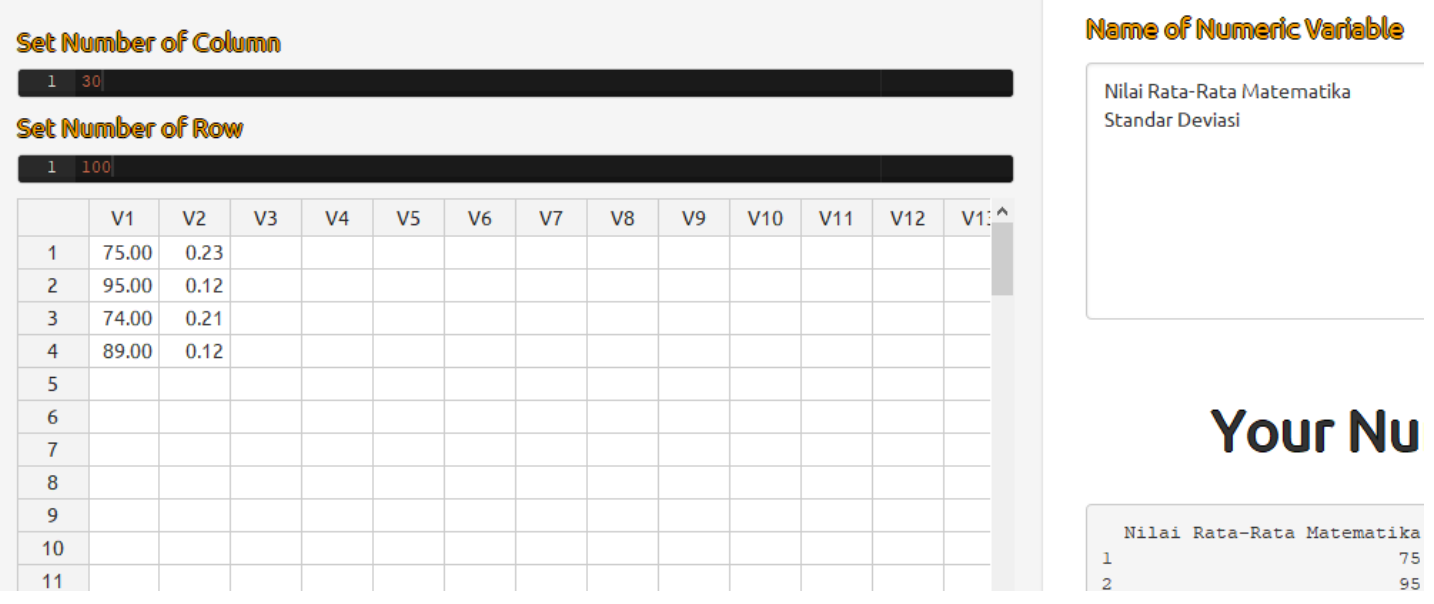

Gambar 1.3 Input Data Numerik pada Menu Bar: Other-IV 


\section{Bar: Other-IV}

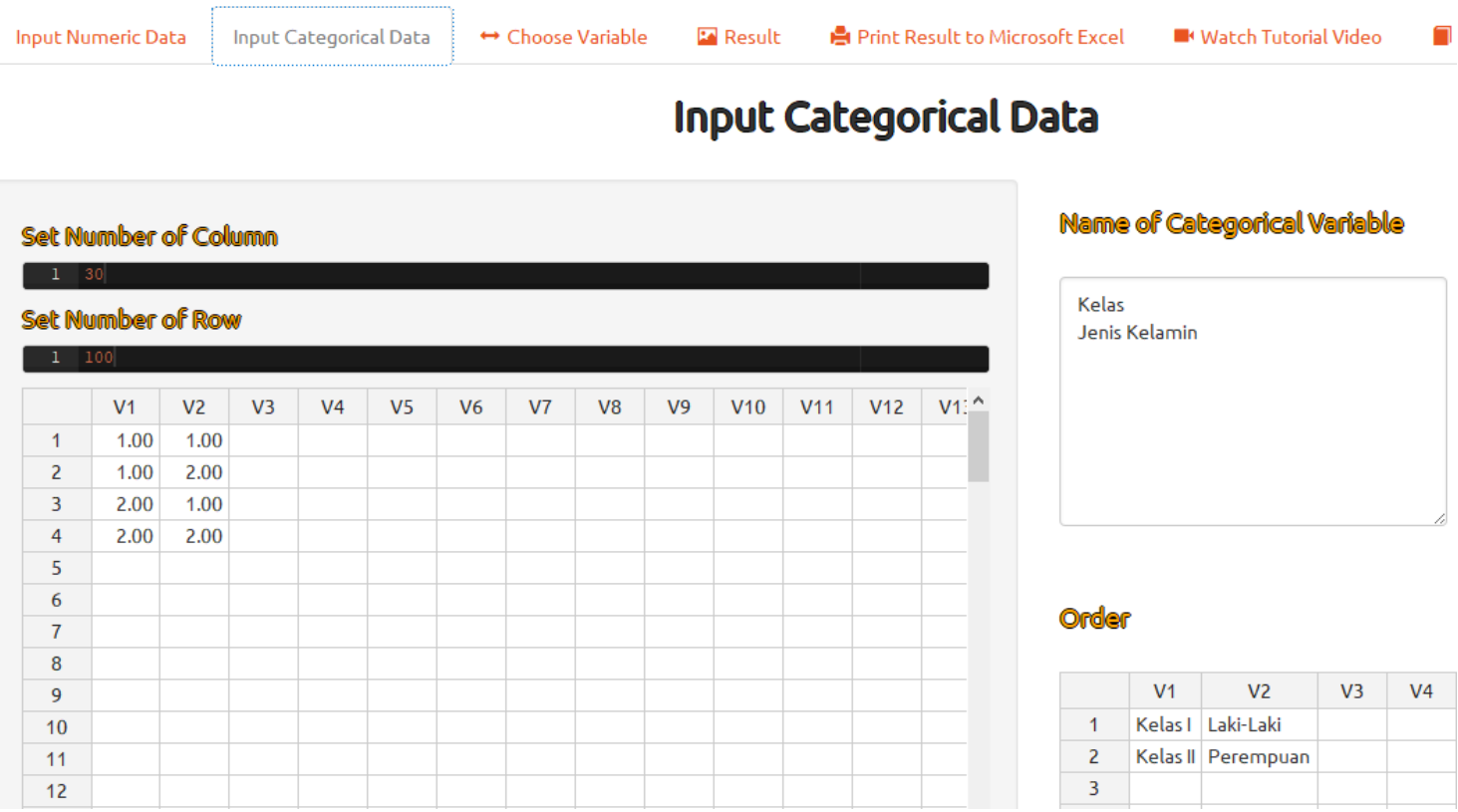

\section{Gambar 1.4 Input Data Kategori pada Menu Bar: Other-IV}

Pada bagian Choose Variable, Lakukan pemilihan variabel seperti pada Gambar 1.5.
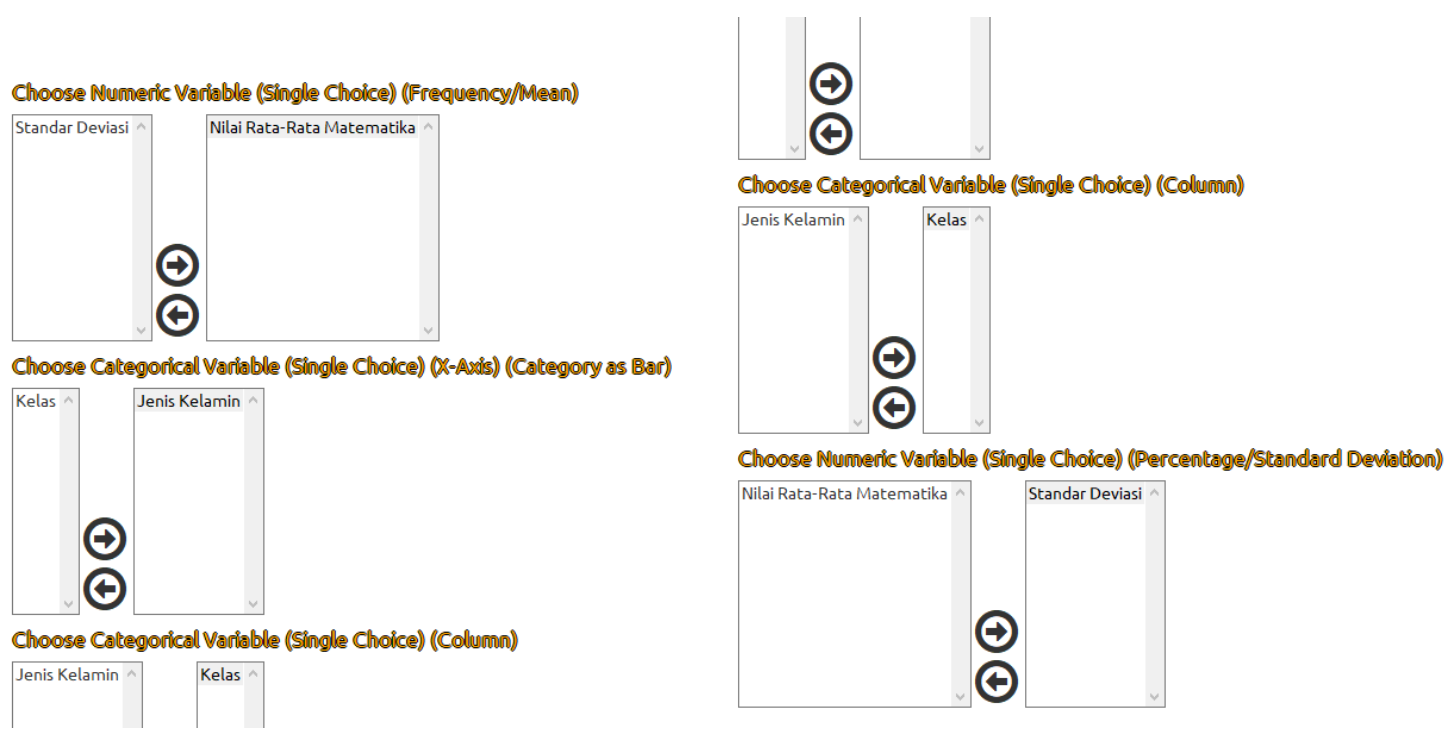

Gambar 1.5 Pemilihan Variabel 
Hasil dari grafik batang rata-rata dapat dilihat pada bagian Result $=>$ Print Result (Gambar 1.6).

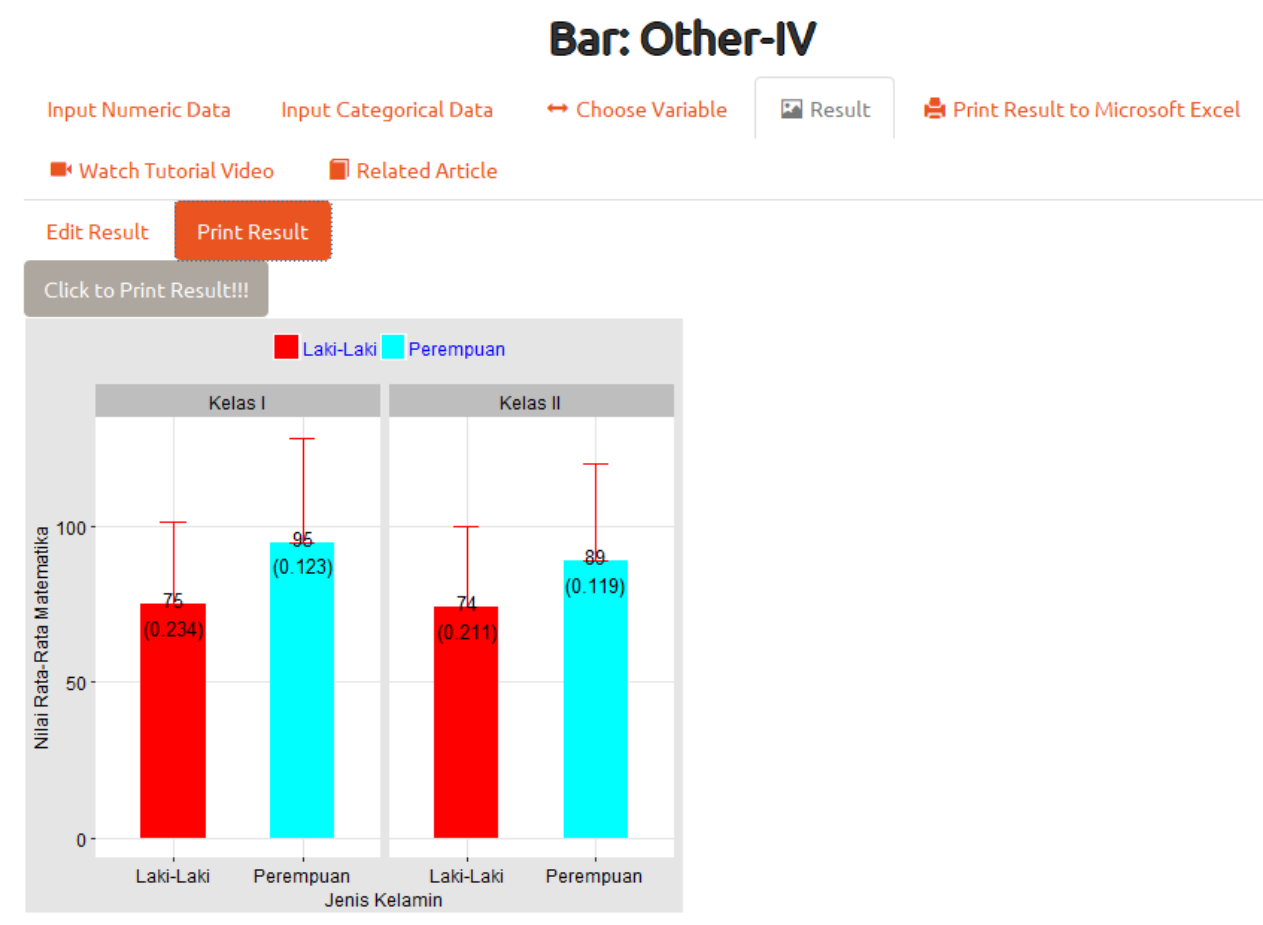

Gambar 1.6 Grafik Batang Rata-Rata

Hasil dari grafik batang rata-rata juga dapat dicetak ke dalam Microsoft Excel dengan menggunakan menu Print Result to Microsoft Excel. 


\section{Mengolah Data dengan}

Program Aplikasi Statistika

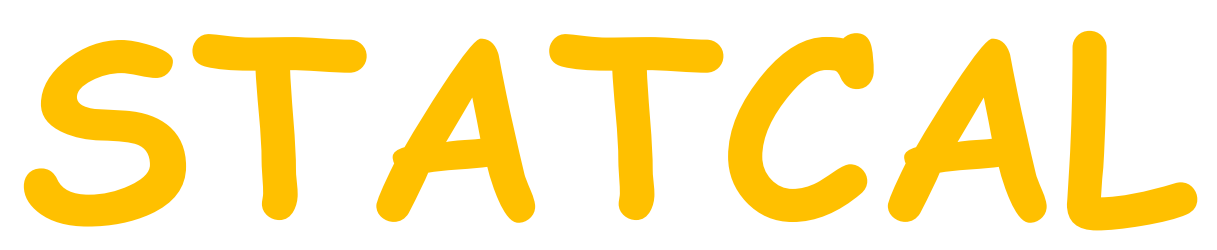

Membuat Grafik Batang Frekuensi dengan Menu

Bar: Other-V

\section{Oleh Prana Ugiana Gio}

Founder \& CEO STATCAL

Created by Prana Ugiana Gio \& Rezzy Eko Caraka

Ill Bar: Average Ill Bar: Frequency dil Bar: other

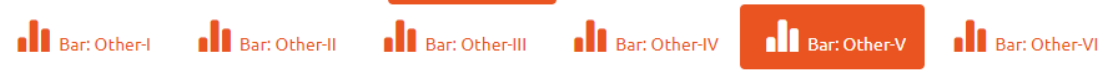

Bar: Other-V
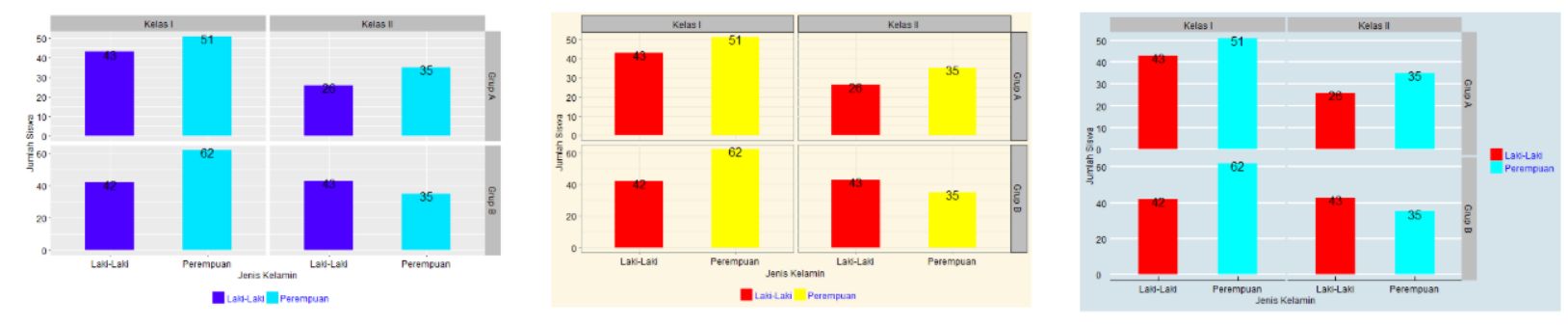
Misalkan diberikan data jumlah siswa berdasarkan jenis kelamin, kelas dan grup (Tabel 1.1).

Tabel 1.1 Data Hobi dari 11 Responden (Data Fiktif)

\begin{tabular}{|c|c|c|c|}
\hline Jenis Kelamin & Kelas & Grup & Jumlah Siswa \\
\hline 1 & 1 & 1 & 43 \\
\hline 1 & 1 & 2 & 42 \\
\hline 1 & 2 & 1 & 26 \\
\hline 1 & 2 & 2 & 43 \\
\hline 2 & 1 & 1 & 51 \\
\hline 2 & 1 & 2 & 62 \\
\hline 2 & 2 & 1 & 35 \\
\hline 2 & 2 & 2 & 35 \\
\hline
\end{tabular}

\begin{tabular}{|c|c|c|}
\hline Jenis Kelamin & Kelas & Grup \\
\hline Laki-Laki & Kelas I & Grup A \\
\hline Perempuan & Kelas II & Grup B \\
\hline
\end{tabular}

Berdasarkan data pada Tabel 1.1, diketahui:

$\Rightarrow$ Jumlah siswa laki-laki, pada kelas I, grup A sebanyak 43 siswa.

$\Rightarrow$ Jumlah siswa laki-laki, pada kelas I, grup B sebanyak 42, dan seterusnya.

Dari data pada Tabel 1.1, disajikan grafik batang frekuensi seperti pada Gambar 1.1.

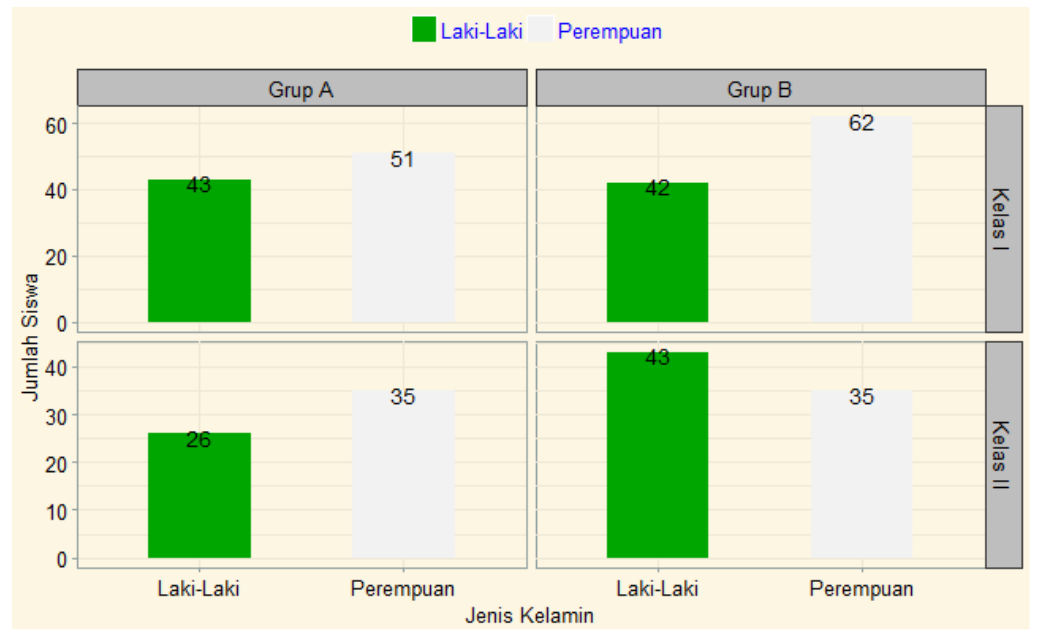

Gambar 1.1 Grafik Batang Frekuensi 
Untuk membuat grafik batang frekuensi pada Gambar 1.1, kita akan menggunakan menu Bar: Other-V (Gambar 1.2).

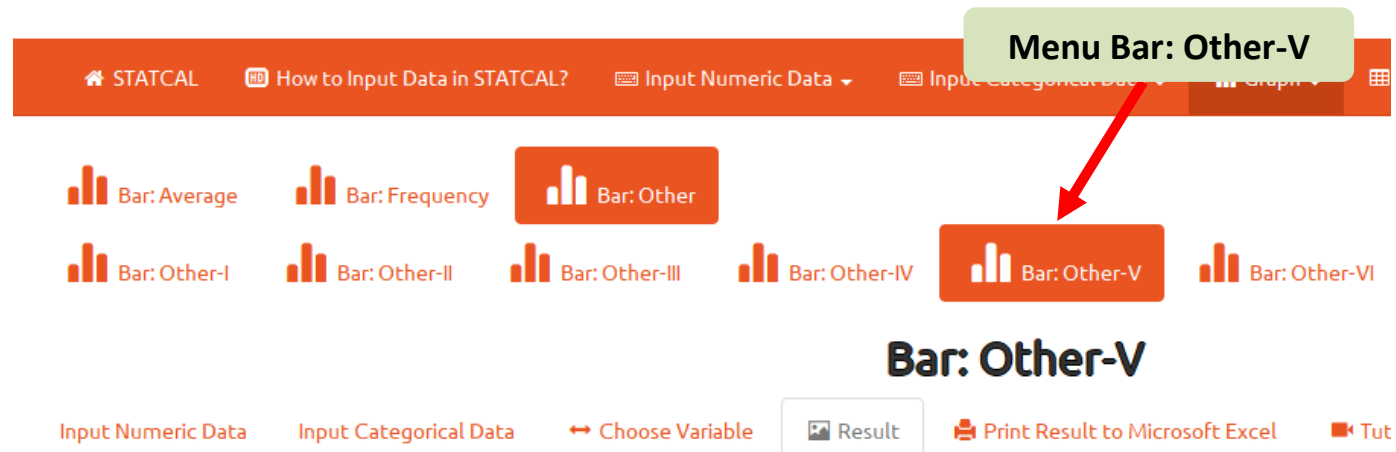

Gambar 1.2 Menu Bar: Other-V

Untuk mengakses menu Bar: Other-V, pilih Graph => Bar => Bar: Other => Bar: OtherV(Gambar 1.2). Dengan menggunakan data pada Tabel 1.1, input data seperti pada Gambar 1.3 (untuk data numerik) dan Gambar 1.4 (untuk data kategori).

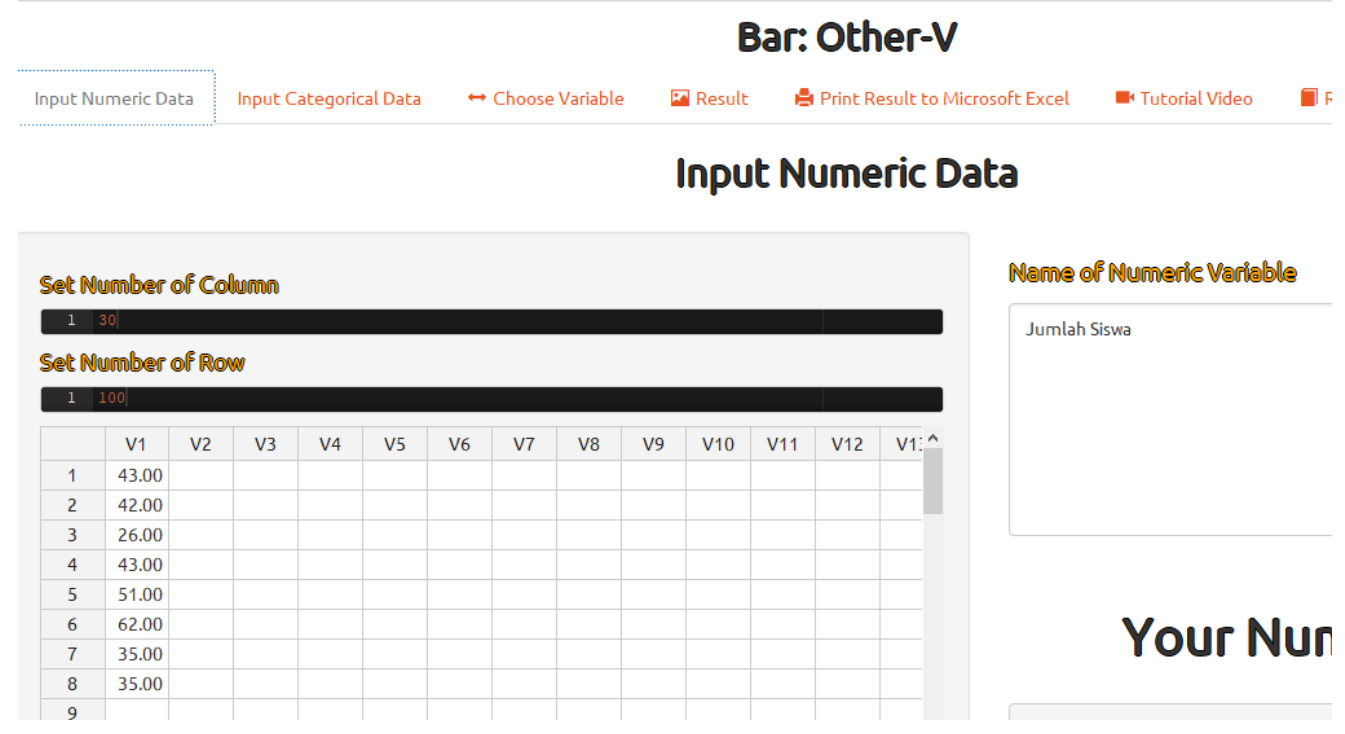

Gambar 1.3 Input Data Numerik pada Menu Bar: Other-V 


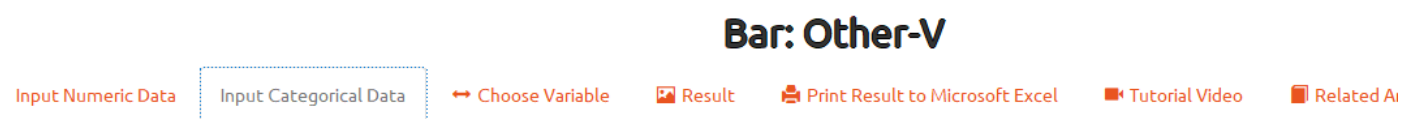

\section{Input Categorical Data}
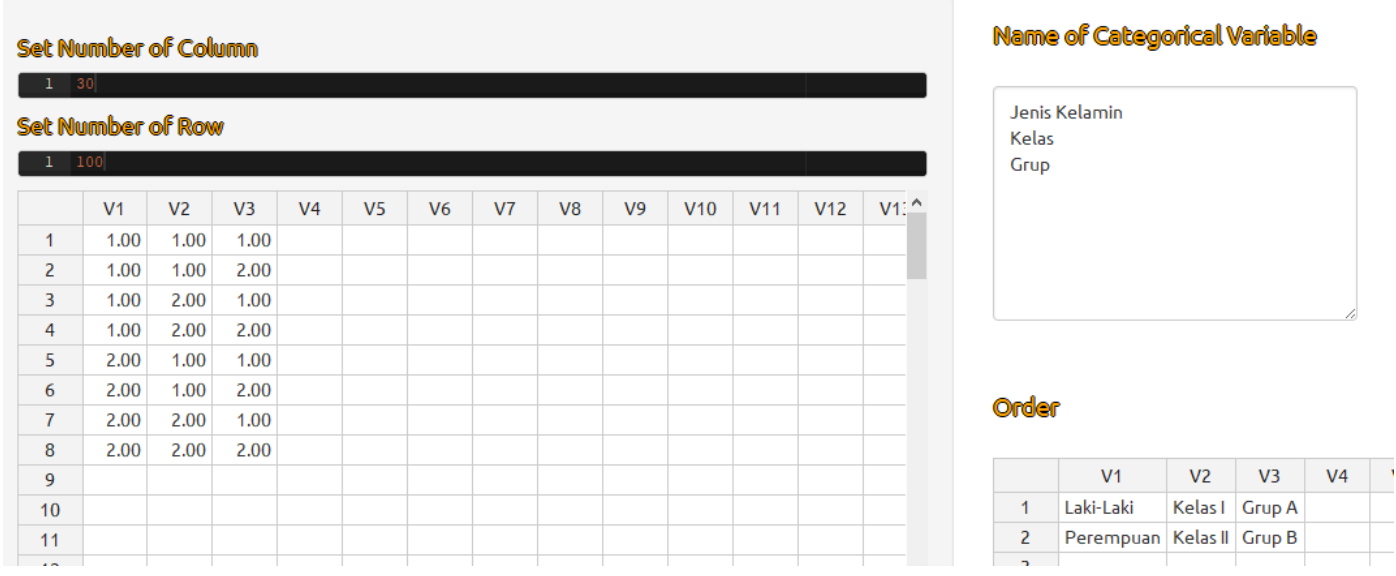

Gambar 1.4 Input Data Kategori pada Menu Bar: Other-V

Lakukan pemilihan variabel pada bagian Choose Variable, seperti pada Gambar 1.5.

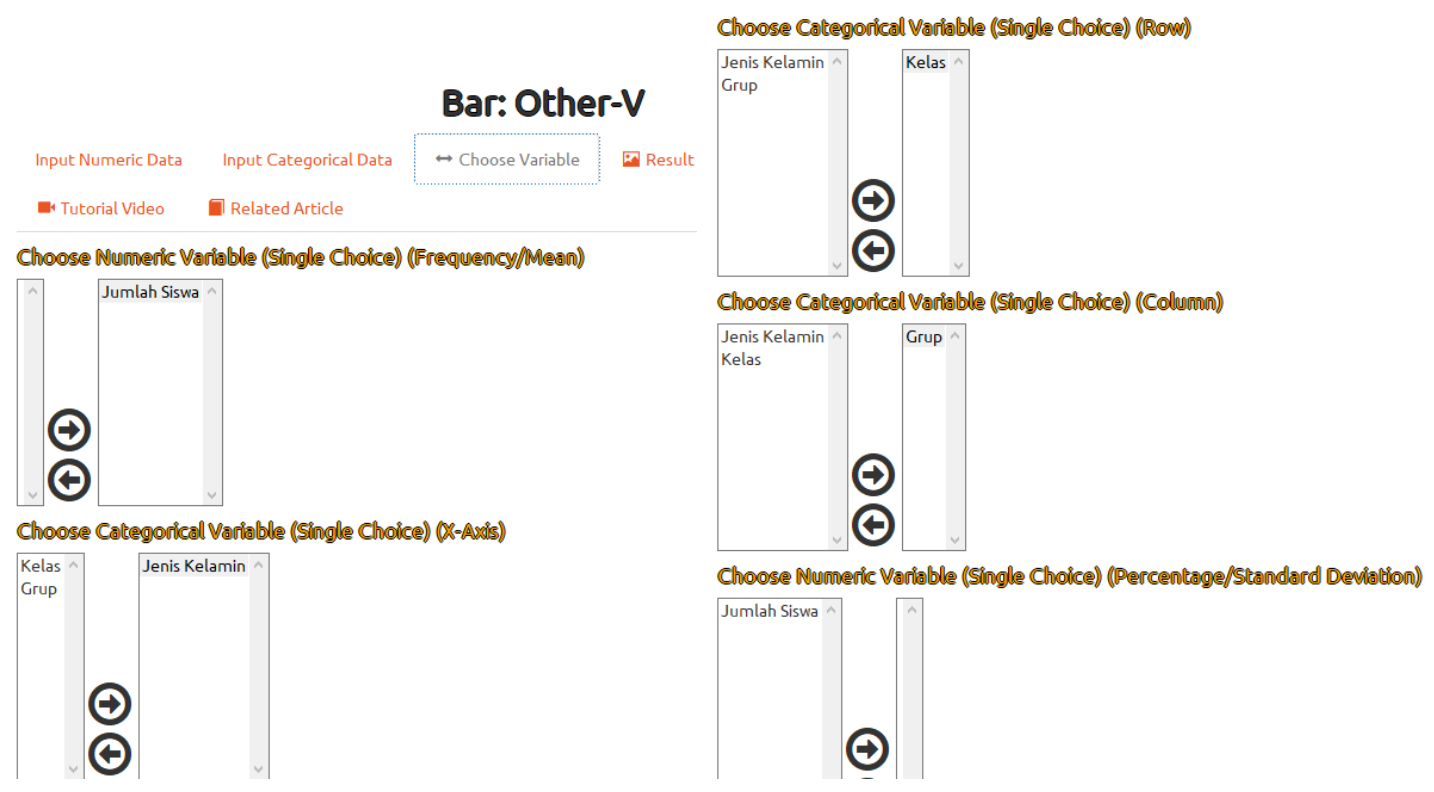

Gambar 1.5 Pemilihan Variabel 
Hasil dari grafik batang frekuensi dapat dilihat pada bagian Result $=>$ Print Result $($ Gambar 1.6)

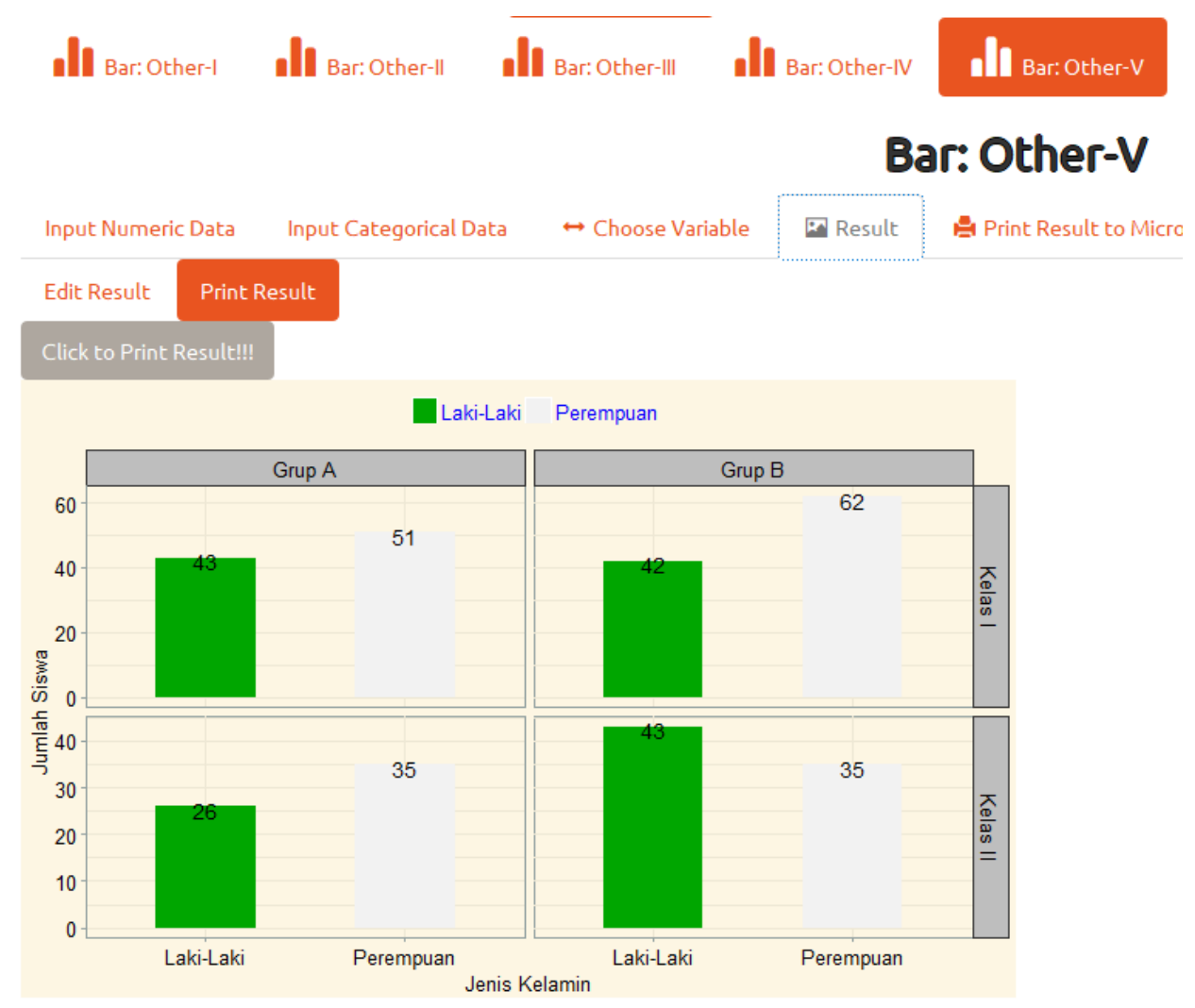

Gambar 1.6 Grafik Batang Frekuensi

Hasil dari grafik batang frekuensi juga dapat dicetak ke dalam Microsoft Excel dengan menggunakan menu Print Result to Microsoft Excel. 


\section{Mengolah Data dengan}

Program Aplikasi Statistika

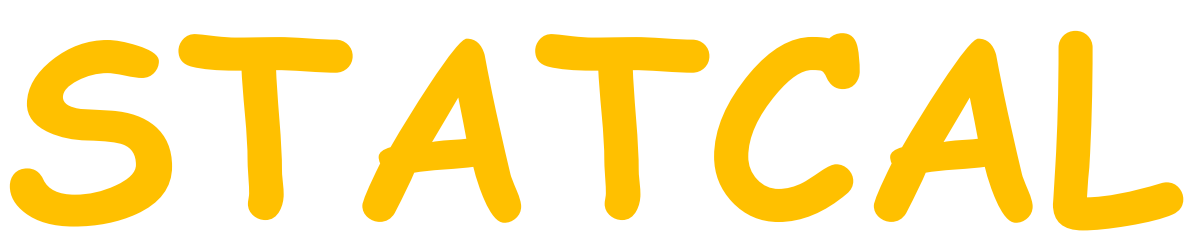

Membuat Grafik Batang Rata-Rata dengan Menu Bar: Other-V

Oleh Prana Ugiana Gio

Founder \& CEO STATCAL

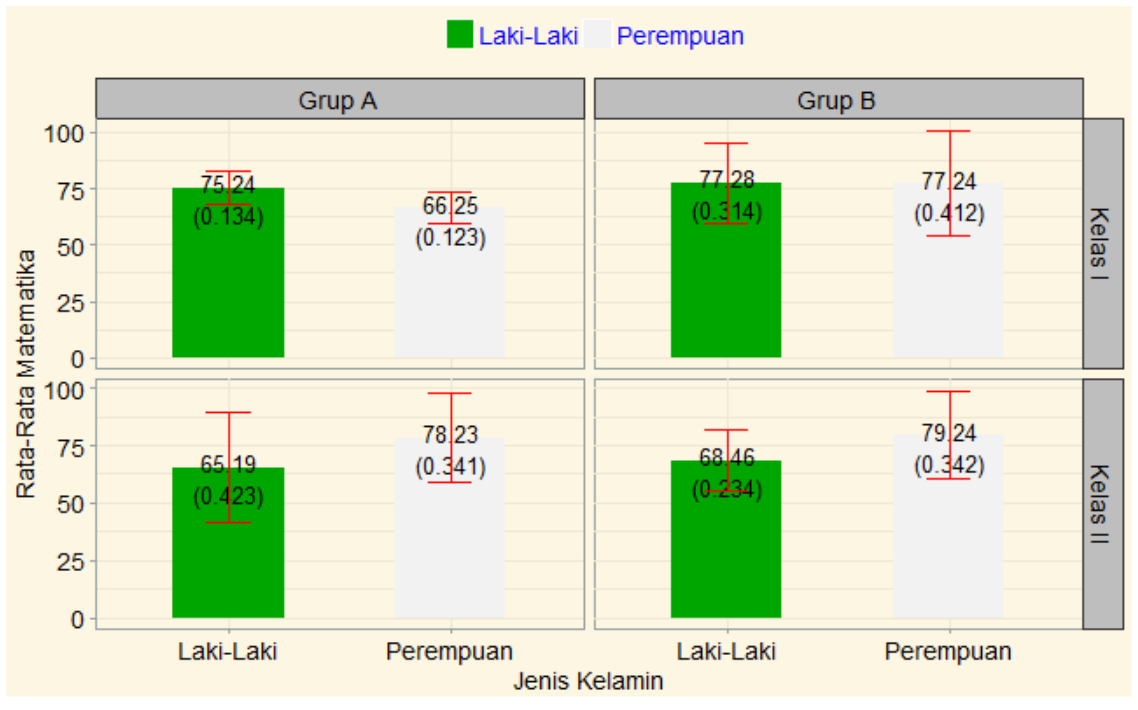


Misalkan diberikan data rata-rata nilai matematika berdasarkan jenis kelamin, kelas dan grup (Tabel 1.1).

Tabel 1.1 Data Rata-Rata Nilai Matematika berdasarkan Jenis Kelamin, Kelas dan Grup (Data Fiktif)

\begin{tabular}{|c|c|c|c|c|}
\hline Jenis Kelamin & Kelas & Grup & Rata-Rata Nilai Matematika & Standar Deviasi \\
\hline 1 & 1 & 1 & 75.24 & 0.134 \\
\hline 1 & 1 & 2 & 77.28 & 0.314 \\
\hline 1 & 2 & 1 & 65.19 & 0.423 \\
\hline 1 & 2 & 2 & 68.46 & 0.234 \\
\hline 2 & 1 & 1 & 66.25 & 0.123 \\
\hline 2 & 1 & 2 & 77.24 & 0.412 \\
\hline 2 & 2 & 1 & 78.23 & 0.341 \\
\hline 2 & 2 & 2 & 79.24 & 0.342 \\
\hline
\end{tabular}

\begin{tabular}{|c|c|c|}
\hline Jenis Kelamin & Kelas & Grup \\
\hline Laki-Laki & Kelas I & Grup A \\
\hline Perempuan & Kelas II & Grup B \\
\hline
\end{tabular}

Berdasarkan data pada Tabel 1.1, diketahui:

$\Rightarrow$ Rata-rata nilai matematika laki-laki, kelas I, grup A adalah 75,24, dengan standar deviasi 0,134 .

$\Rightarrow$ Rata-rata nilai matematika laki-laki, kelas I, grup B adalah 77,28, dengan standar deviasi 0,314 , dan seterusnya.

Dari data pada Tabel 1.1, disajikan grafik batang rata-rata seperti pada Gambar 1.1. 


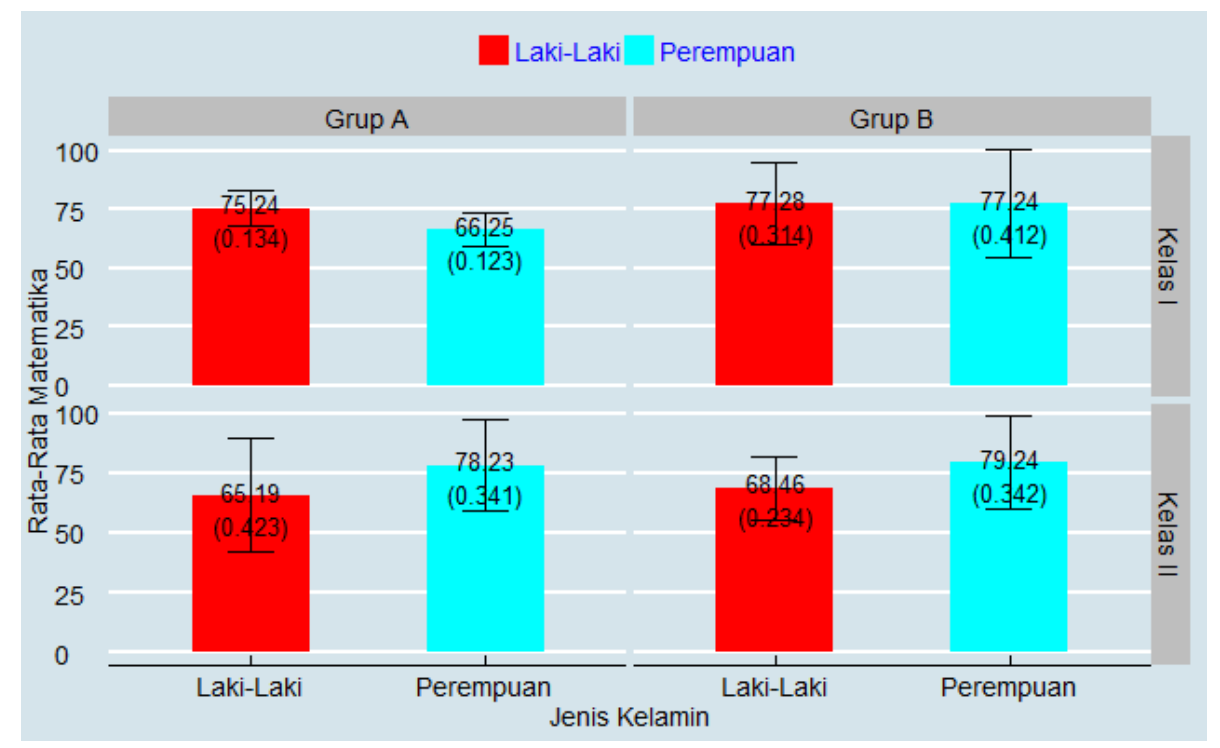

Gambar 1.1 Grafik Batang Rata-Rata

Untuk membuat grafik batang rata-rata pada Gambar 1.1, kita akan menggunakan menu Bar: Other-V (Gambar 1.2).

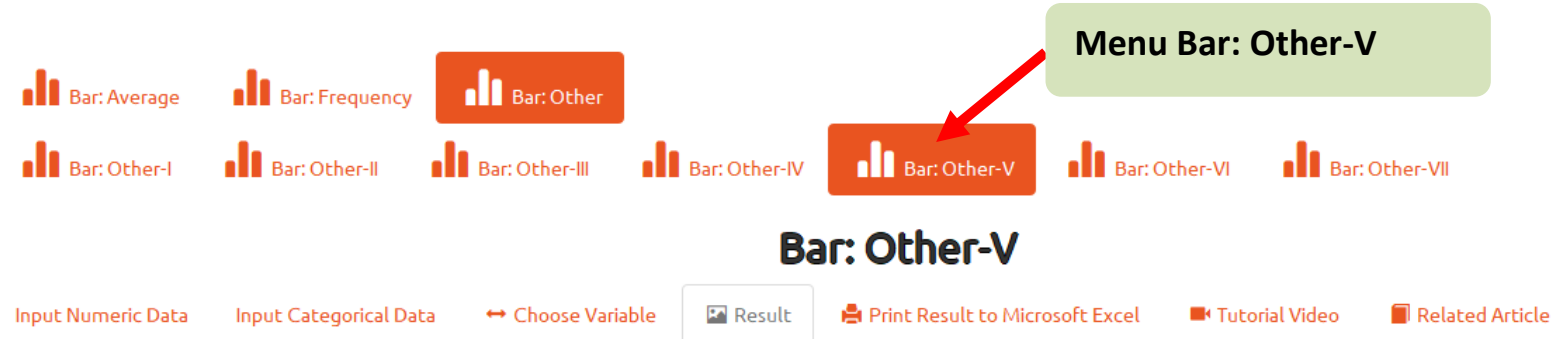

\section{Gambar 1.2 Menu Bar: Other-V}

Untuk mengakses menu Bar: Other-V, pilih Graph => Bar => Bar: Other => Bar: Other-V (Gambar 1.2). Dengan menggunakan data pada Tabel 1.1, input data seperti pada Gambar 1.3 (data numerik) dan Gambar 1.4 (data kategori). 


\section{Bar: Other-V}

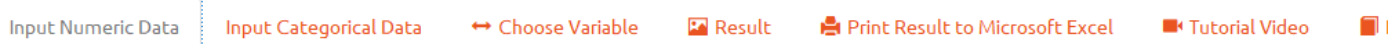

Input Numeric Data

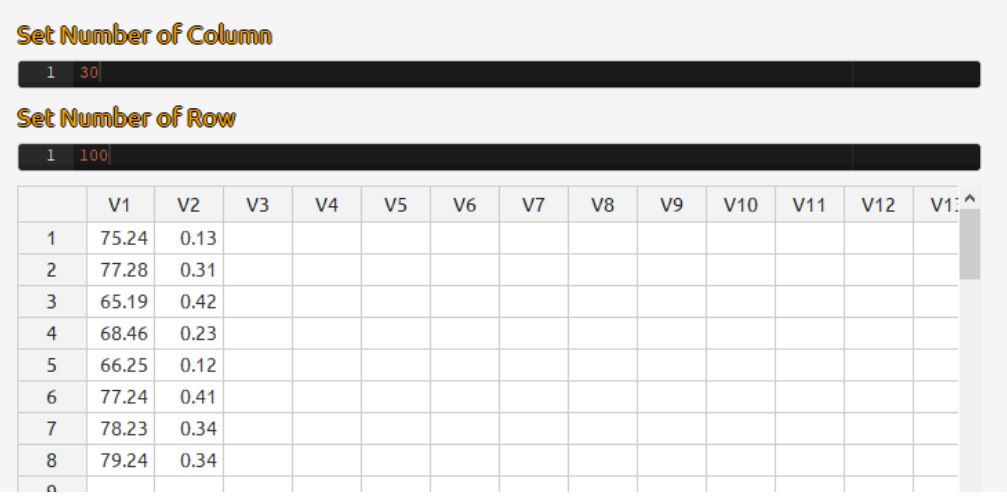

Nanne ô Nunnerie Variable

Rata-Rata Matematika

Standar Deviasi

\section{Gambar 1.3 Input Data Numerik pada Menu Bar: Other-V}

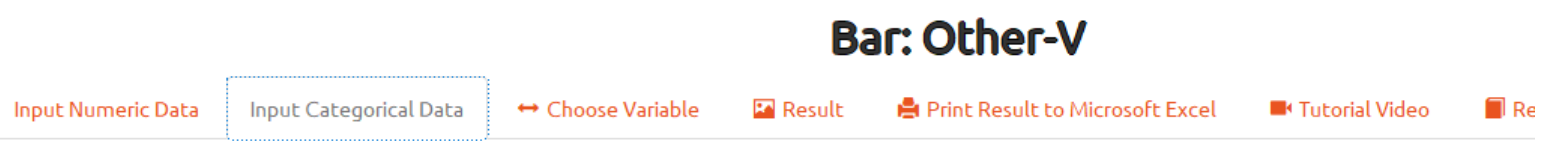

\section{Input Categorical Data}
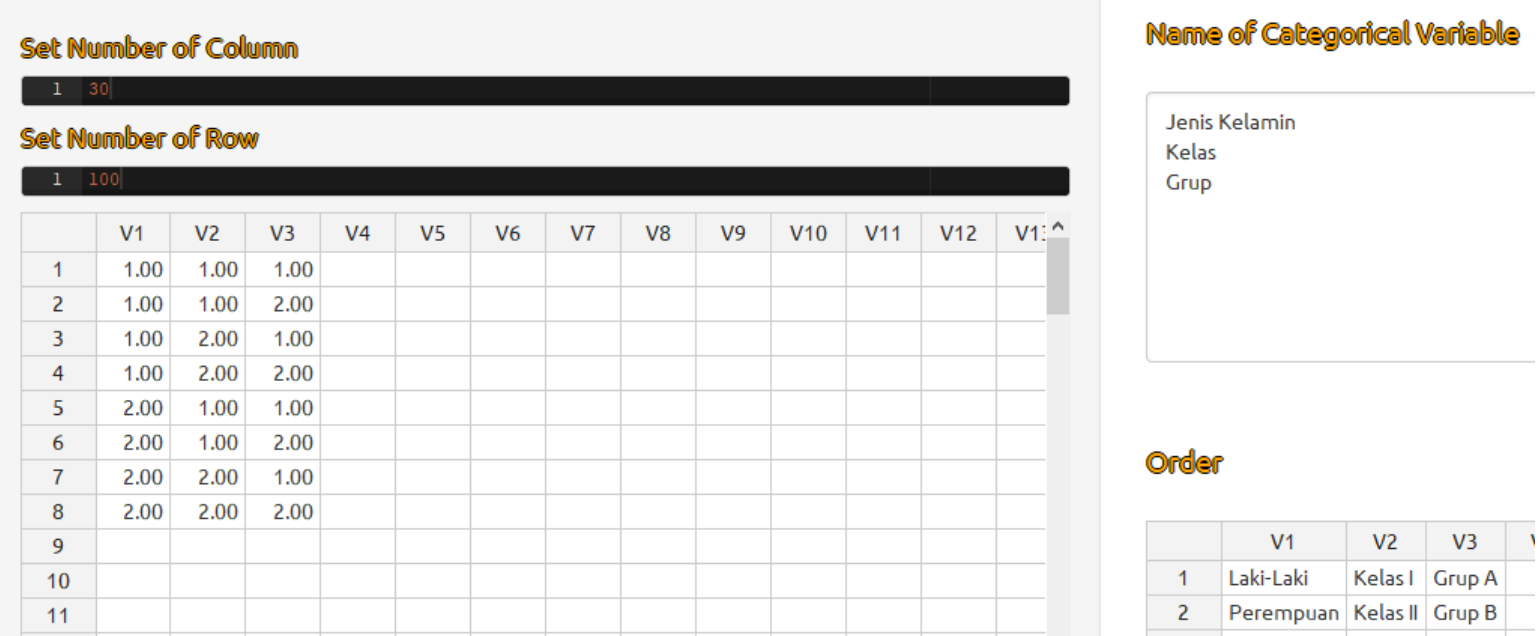

Gambar 1.4 Input Data Kategori pada Menu Bar: Other-V

Pada bagian Choose Variable, Lakukan pemilihan variabel seperti pada Gambar 1.5. 


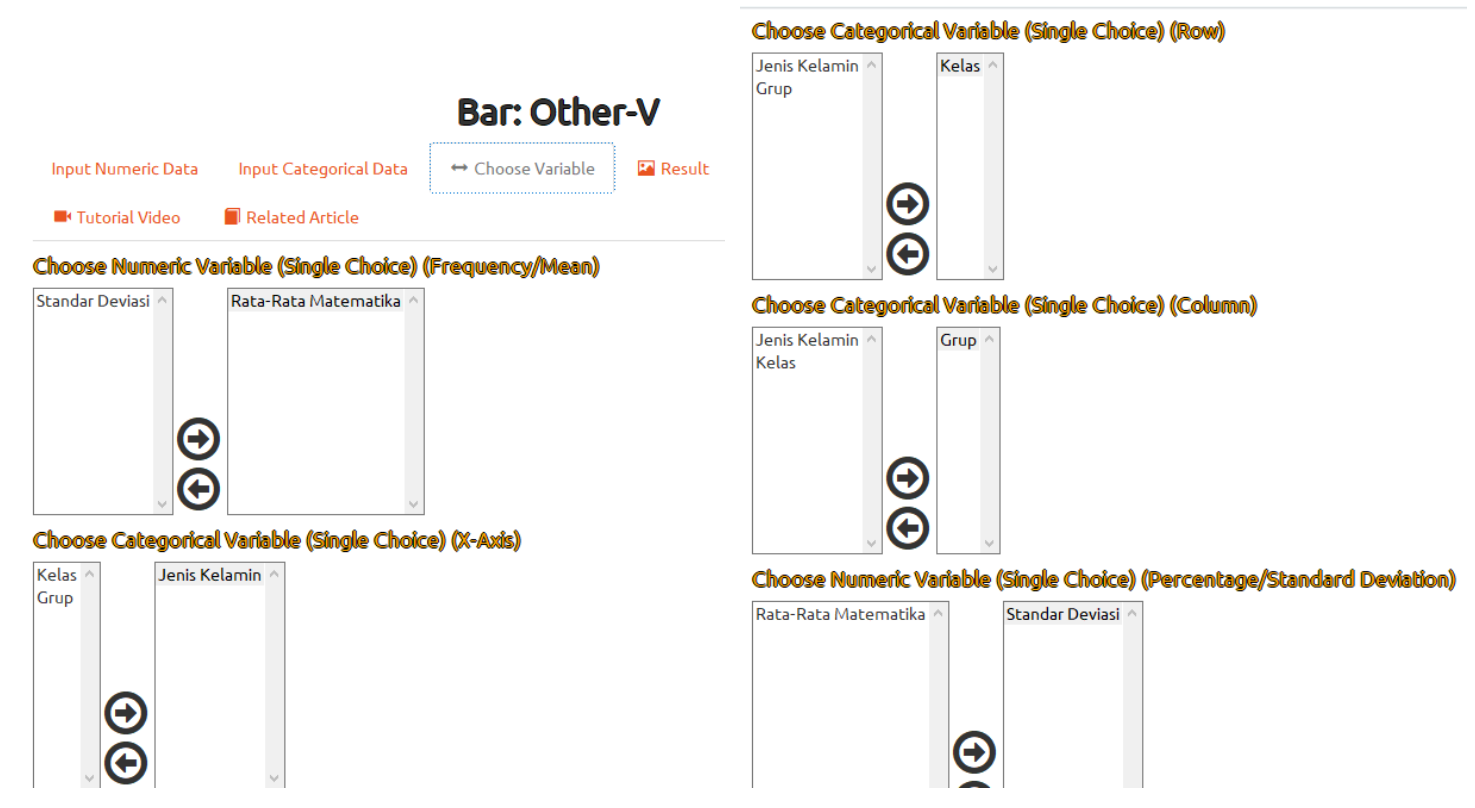

Gambar 1.5 Pemilihan Variabel

Hasil dari grafik batang rata-rata dapat dilihat pada bagian Result $\Rightarrow$ Print Result (Gambar 1.6).

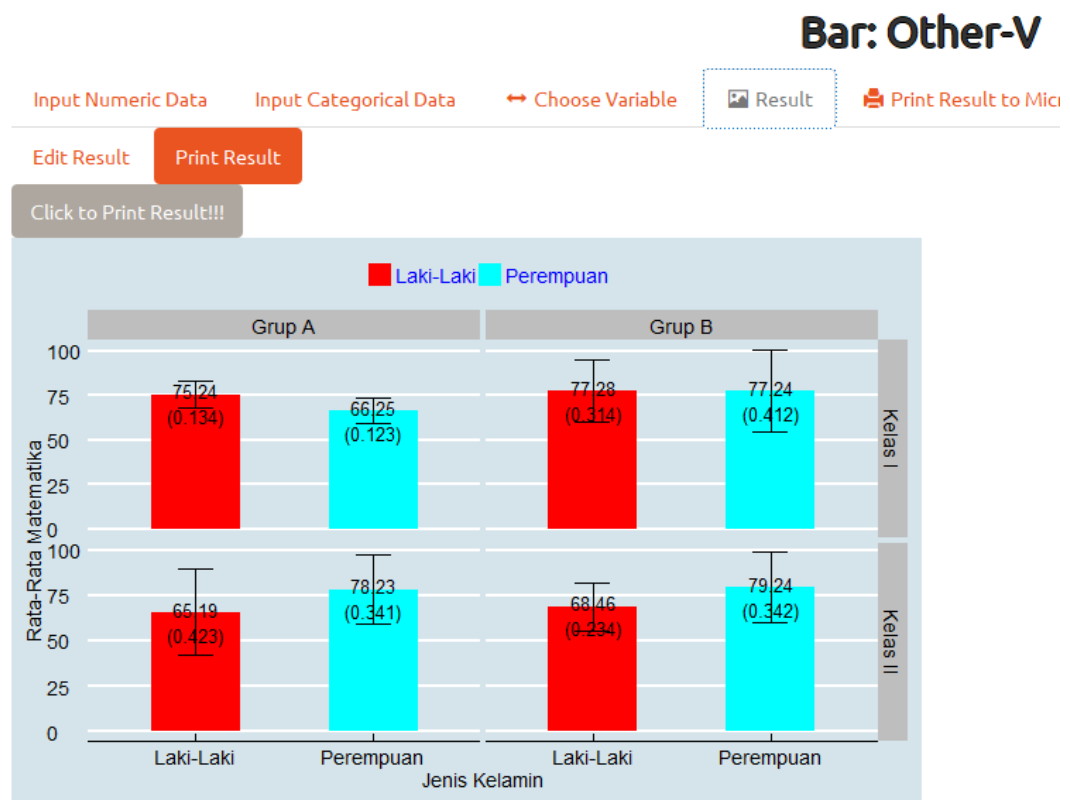

Gambar 1.6 Grafik Batang Rata-Rata 
Hasil dari grafik batang rata-rata juga dapat dicetak ke dalam Microsoft Excel dengan menggunakan menu Print Result to Microsoft Excel. 


\section{Mengolah Data dengan}

Program Aplikasi Statistika

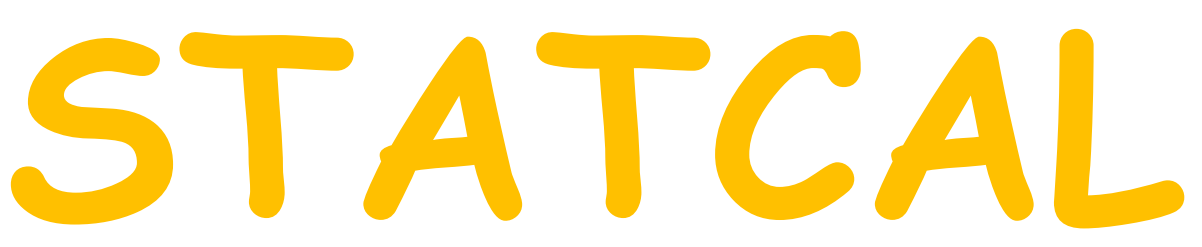

Membuat Grafik Garis Rata-Rata dengan Menu

Line: Average-I

Oleh Prana Ugiana Gio

Founder \& CEO STATCAL

Line: Average-I
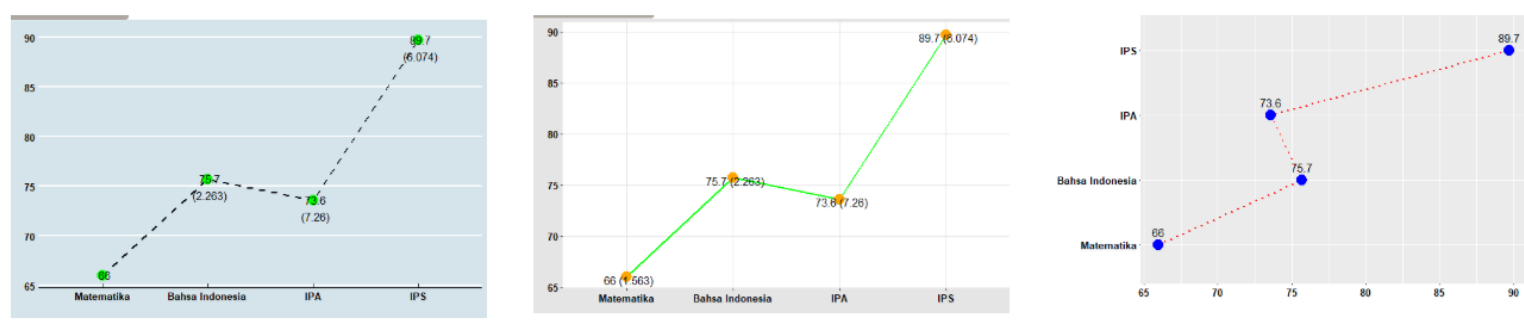
Misalkan diberikan data nilai ujian matematika, bahasa Indonesia, IPA dan IPS dari 10 siswa (Tabel 1.1).

\section{Tabel 1.1 Data Nilai Ujian Matematika, Bahasa Indonesia, IPA dan IPS dari 10 Siswa (Data Fiktif)}

\begin{tabular}{|c|c|c|c|c|}
\hline Nama & Matematika & Bahasa Indonesia & IPA & IPS \\
\hline Andi & 67 & 71 & 66 & 89 \\
\hline Ugi & 66 & 77 & 67 & 88 \\
\hline Edi & 65 & 75 & 67 & 87 \\
\hline Rani & 67 & 78 & 88 & 89 \\
\hline Rini & 65 & 76 & 76 & 98 \\
\hline Dina & 64 & 77 & 77 & 94 \\
\hline Fitri & 69 & 75 & 76 & 78 \\
\hline Budi & 64 & 79 & 65 & 99 \\
\hline Santoso & 66 & 74 & 78 & 87 \\
\hline Dono & 67 & 75 & 76 & 88 \\
\hline
\end{tabular}

Berdasarkan data pada Tabel 1.1, diketahui siswa yang bernama Ugi, memperoleh nilai matematika 67, nilai bahasa Indonesia 71, nilai IPA 66 dan nilai IPS 89. Dari data pada Tabel 1.1, disajikan grafik garis rata-rata seperti pada Gambar 1.1.

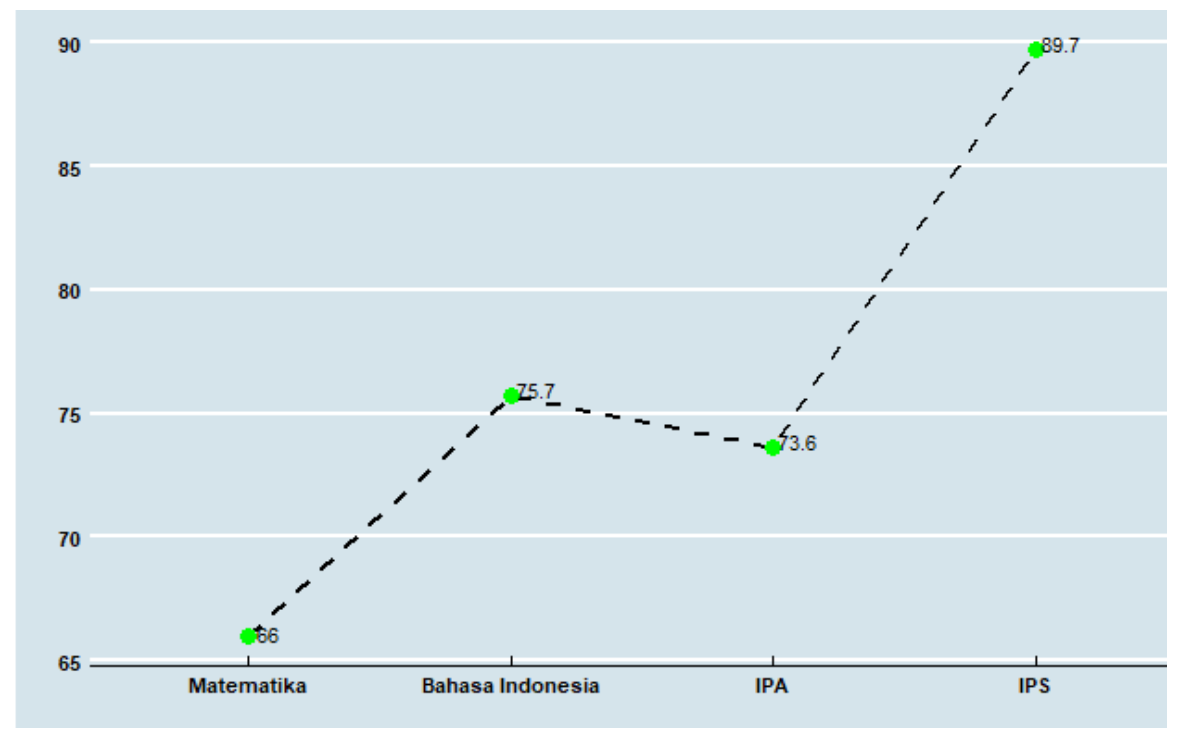

Gambar 1.1 Grafik Garis Rata-Rata 
Berdasarkan grafik garis rata-rata pada Gambar 1.1, diketahui:

$\Rightarrow$ Rata-rata nilai matematika adalah 66, dengan standar deviasi 1,56.

$\Rightarrow$ Rata-rata nilai bahasa Indonesia adalah 75,7, dengan standar deviasi 2,26, dan seterusnya.

Untuk membuat grafik garis rata-rata pada Gambar 1.1, kita akan menggunakan menu Line: Average-I (Gambar 1.2).

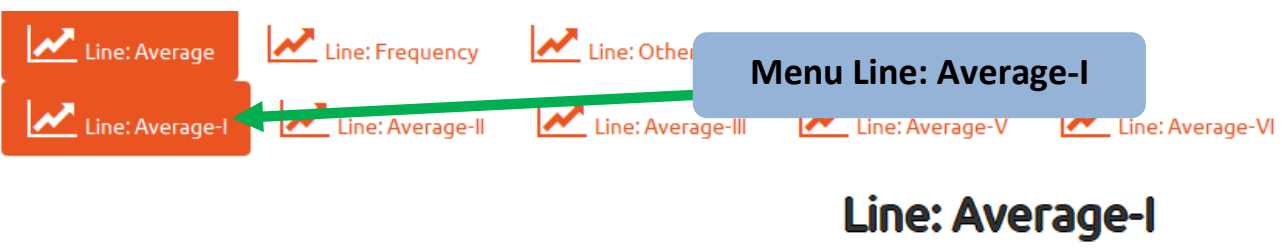

Gambar 1.2 Menu Line: Average-I

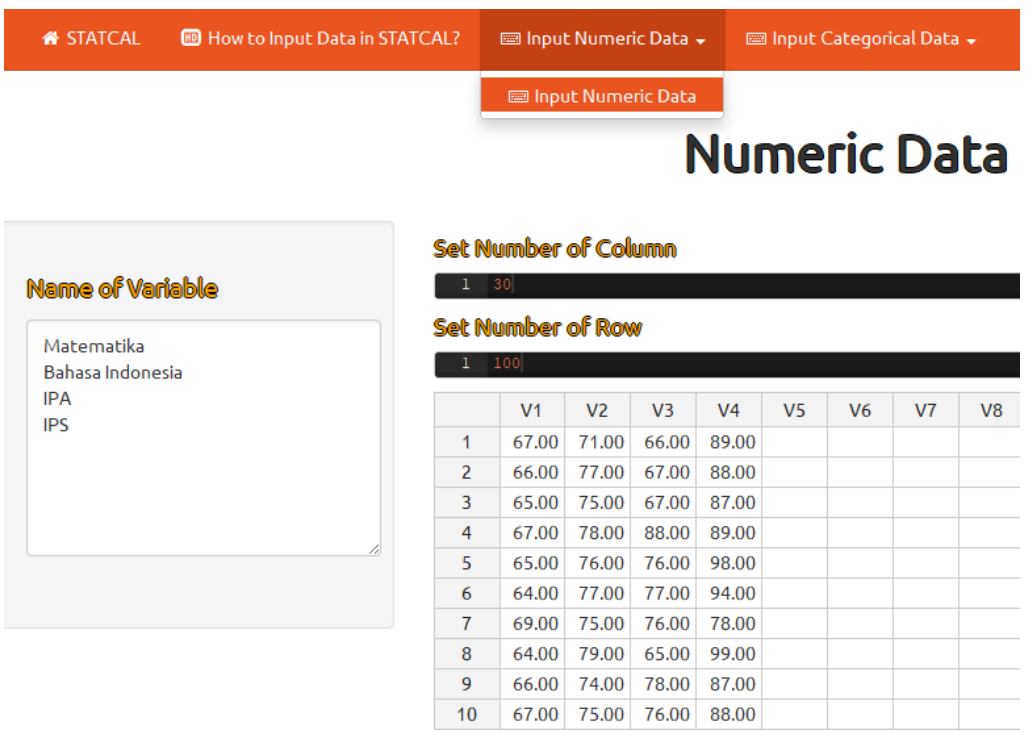

Gambar 1.3 Input Data Numerik pada Bagian Input Numeric Data

Langkah pertama adalah input data pada Tabel 1.1 ke dalam STATCAL seperti pada Gambar

1.3. Perhatikan bahwa data diinput pada bagian Input Numeric Data. Selanjutnya kita akan 
mengakses menu Line: Average-I dengan memilih Graph $=>$ Line $=>$ Line: Average $=>$ Line: Average-I (Gambar 1.4).

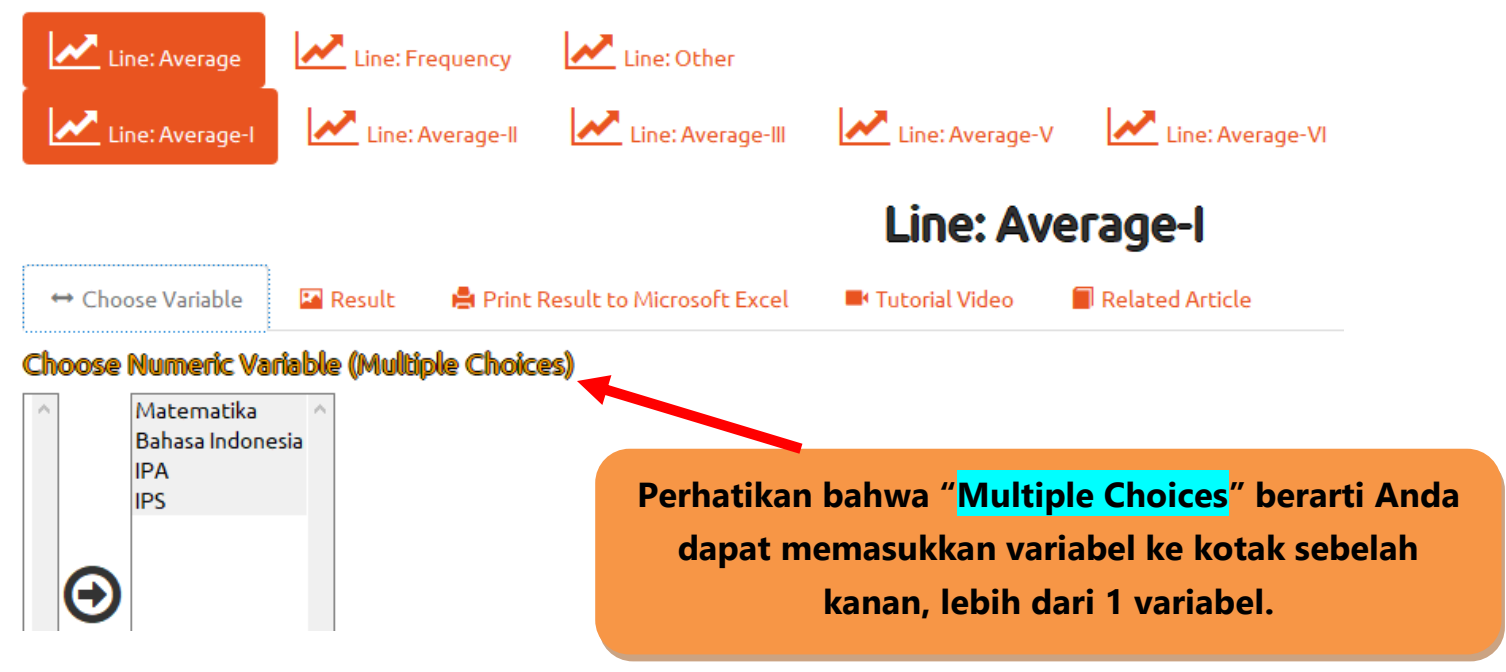

Gambar 1.4 Menu Line: Average-I

Pada Gambar 1.4, bagian Choose Numeric Variable (Multiple Choices), pindahkan seluruh variabel ke kotak sebelah kanan. Gambar 1.5 merupakan keterangan beberapa menu pada Line: Average-I.

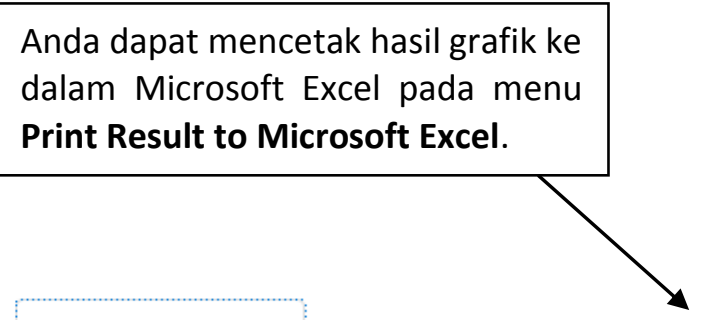
$\leftrightarrow$ Choose Variable Gambar/ Gambar 1.5

Pada menu Result, Anda dapat melihat hasil grafik dan pengaturan grafik.
Tutorial video terkait membuat grafik Line: Average-I dapat dilihat pada bagian Tutorial Video. Untuk memutar video tersebut, pastikan terkoneksi internet!!!

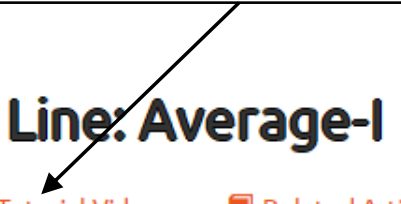

Evt Tutorial Video $\square$ Related Article 
Gambar 1.6 disajikan grafik garis rata-rata.

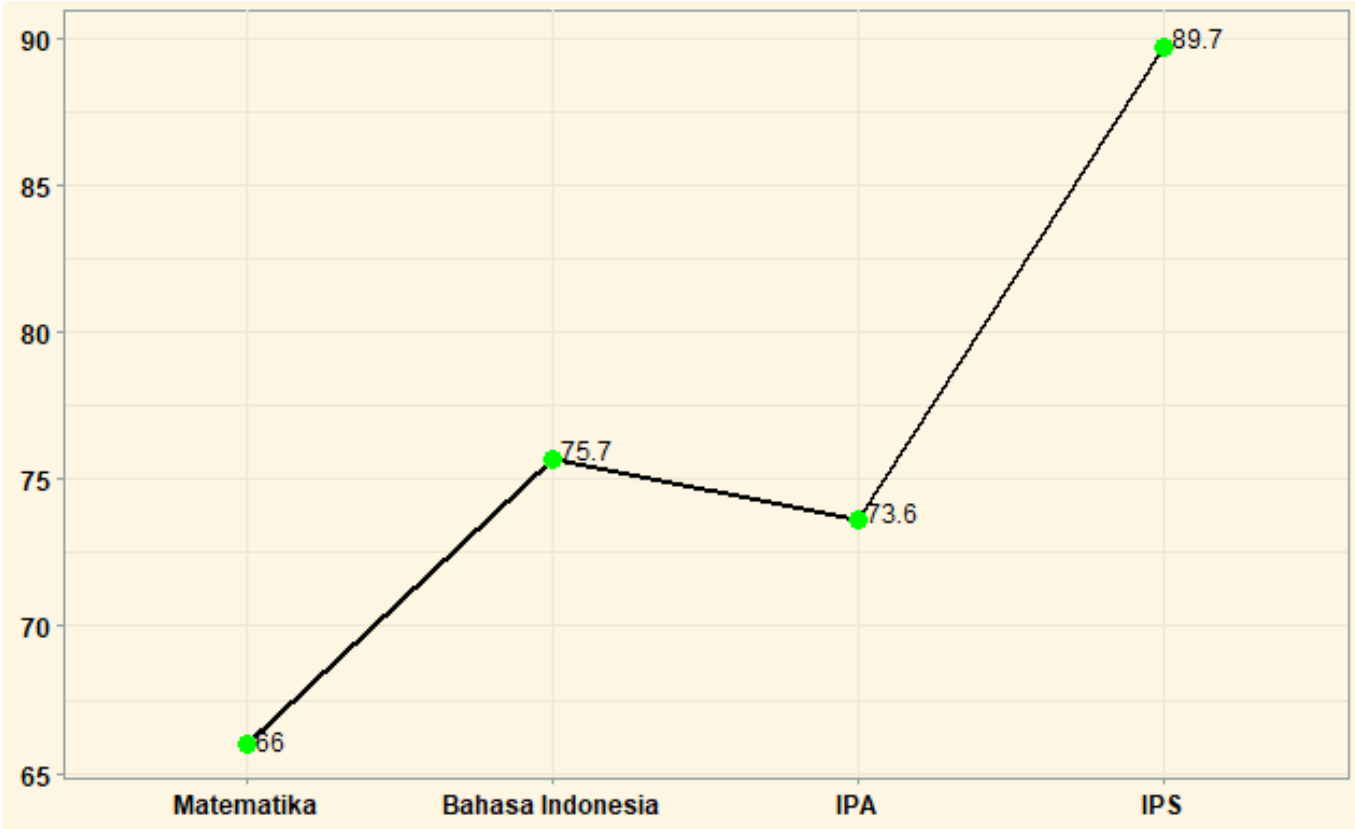

Gambar 1.6 Grafik Garis Rata-Rata 


\section{Mengolah Data dengan}

\section{Program Aplikasi \\ Statistika}

Membuat Grafik Garis Rata-Rata dengan Menu

Line: Average-II

Oleh Prana Ugiana Gio

Founder \& CEO STATCAL

Created by Prana Ugiana Gio \& Rezzy Eko Caraka

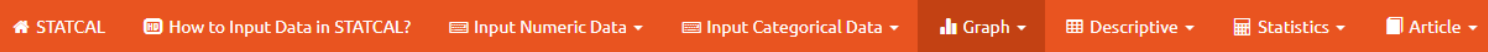

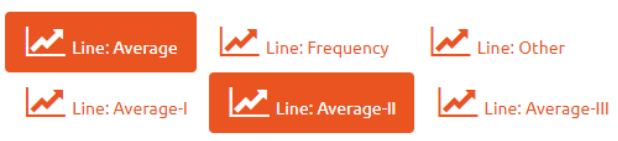

Line: Average-II
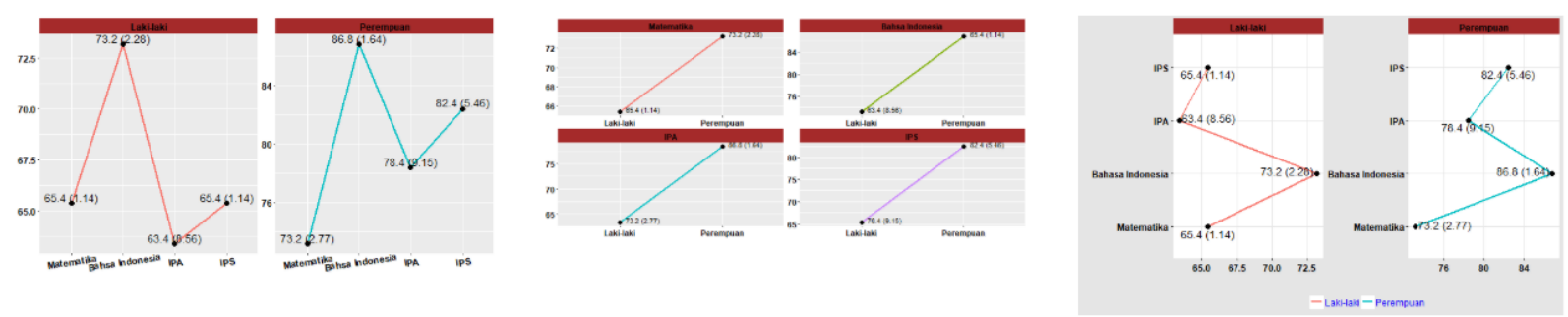
Misalkan diberikan data nilai ujian matematika, bahasa Indonesia, IPA dan IPS, berdasarkan jenis kelamin, dari 10 siswa (Tabel 1.1).

Tabel 1.1 Data Nilai Ujian Matematika, Bahasa Indonesia, IPA dan IPS berdasarkan Jenis Kelamin dari 10 Siswa (Data Fiktif)

\begin{tabular}{|c|c|c|c|c|c|}
\hline Nama & Jenis Kelamin & Matematika & Bahasa Indonesia & IPA & IPS \\
\hline Ugi & 1 & 65 & 71 & 65 & 65 \\
\hline Egi & 1 & 66 & 72 & 67 & 66 \\
\hline Andi & 1 & 67 & 77 & 54 & 67 \\
\hline Anto & 1 & 65 & 73 & 56 & 64 \\
\hline Amar & 1 & 64 & 73 & 75 & 65 \\
\hline Rini & 2 & 71 & 85 & 76 & 85 \\
\hline Rina & 2 & 70 & 88 & 77 & 87 \\
\hline Riri & 2 & 74 & 86 & 87 & 77 \\
\hline Dira & 2 & 77 & 89 & 87 & 87 \\
\hline Fitri & 2 & 74 & 86 & 65 & 76 \\
\hline
\end{tabular}

\begin{tabular}{|c|c|}
\hline \multirow{2}{*}{ Angka } & Label \\
\cline { 2 - 2 } & Jenis Kelamin \\
\hline 1 & Laki-laki \\
\hline 2 & Perempuan \\
\hline
\end{tabular}

Berdasarkan data pada Tabel 1.1, diketahui siswa yang bernama Ugi, dengan jenis kelamin lakilaki, memperoleh nilai matematika 65, nilai bahasa Indonesia 71, nilai IPA 65 dan nilai IPS 65.

Dari data pada Tabel 1.1, disajikan grafik garis rata-rata seperti pada Gambar 1.1 dan Gambar 1.2. 


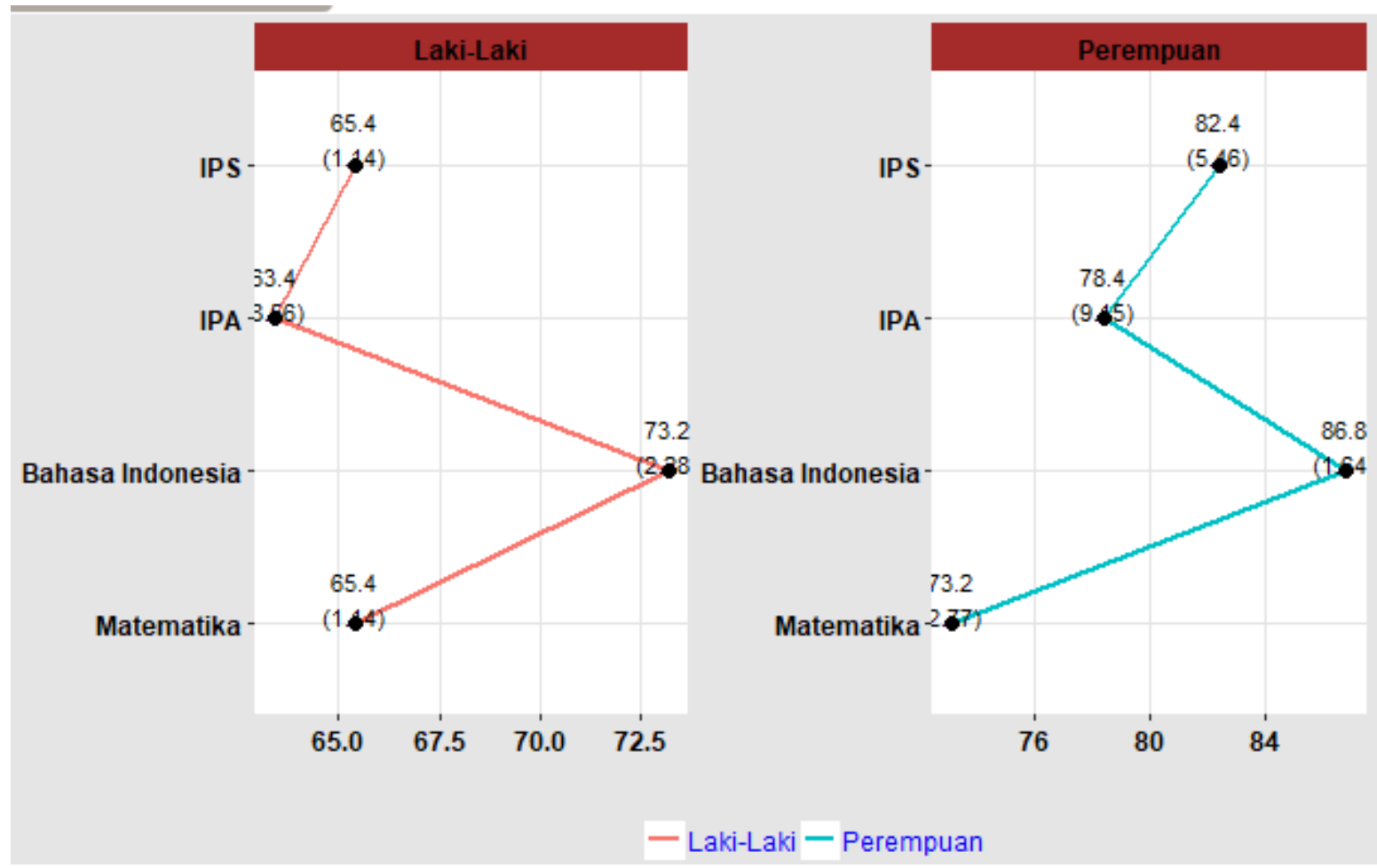

Gambar 1.1 Grafik Garis Rata-Rata

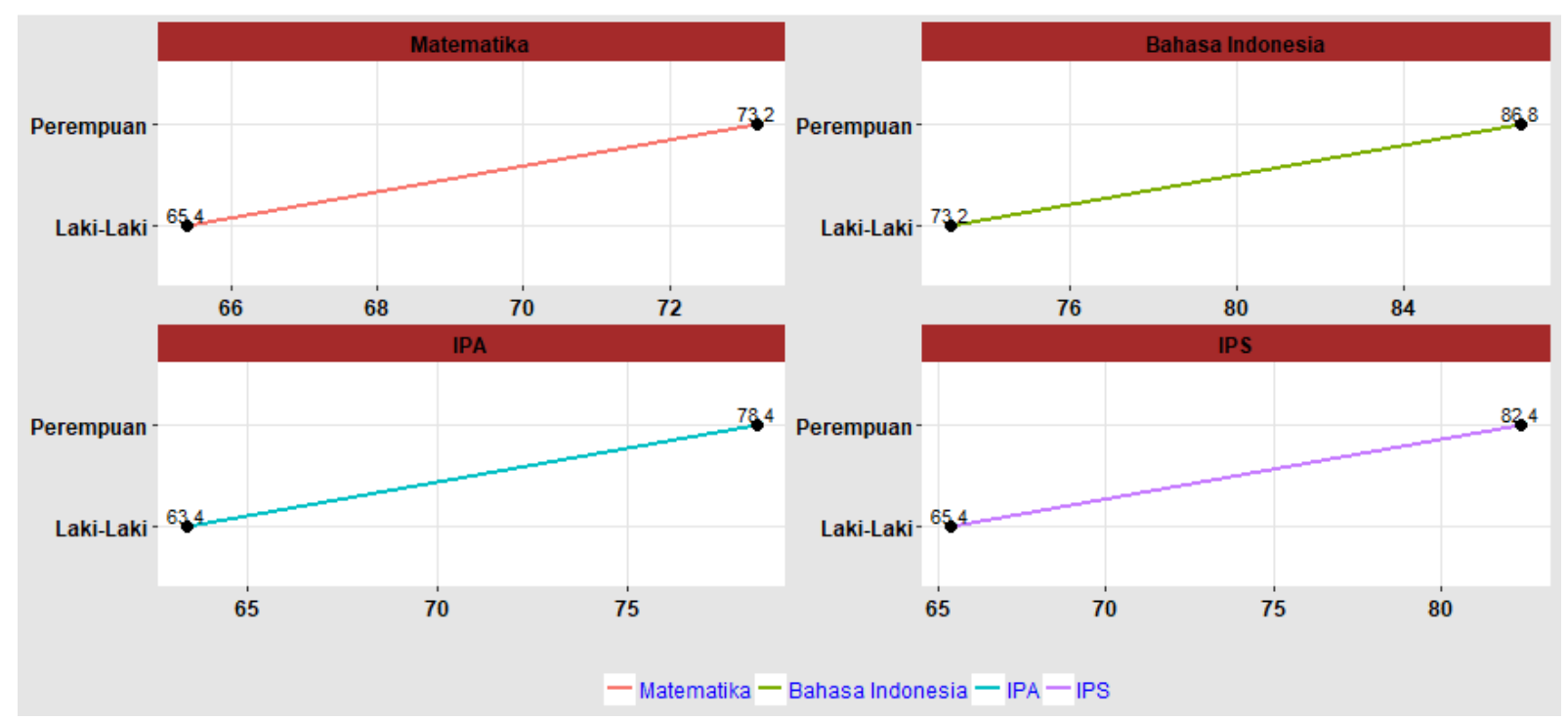

Gambar 1.2 Grafik Garis Rata-Rata

Berdasarkan grafik garis rata-rata pada Gambar 1.1 dan Gambar 1.2, diketahui: 
$\Rightarrow$ Rata-rata nilai matematika laki-laki adalah 65,4, dengan standar deviasi 1,14 . Sementara rata-rata nilai matematika perempuan adalah 73,2, dengan standar deviasi 2,77.

$\Rightarrow$ Rata-rata nilai bahasa indonesia laki-laki adalah 73,2, dengan standar deviasi 2,28. Sementara rata-rata nilai bahasa indonesia perempuan adalah 86,8 , dengan standar deviasi 1,64.

Untuk membuat grafik garis rata-rata pada Gambar 1.1 dan Gambar 1.2, kita akan menggunakan menu Line: Average-II (Gambar 1.3).

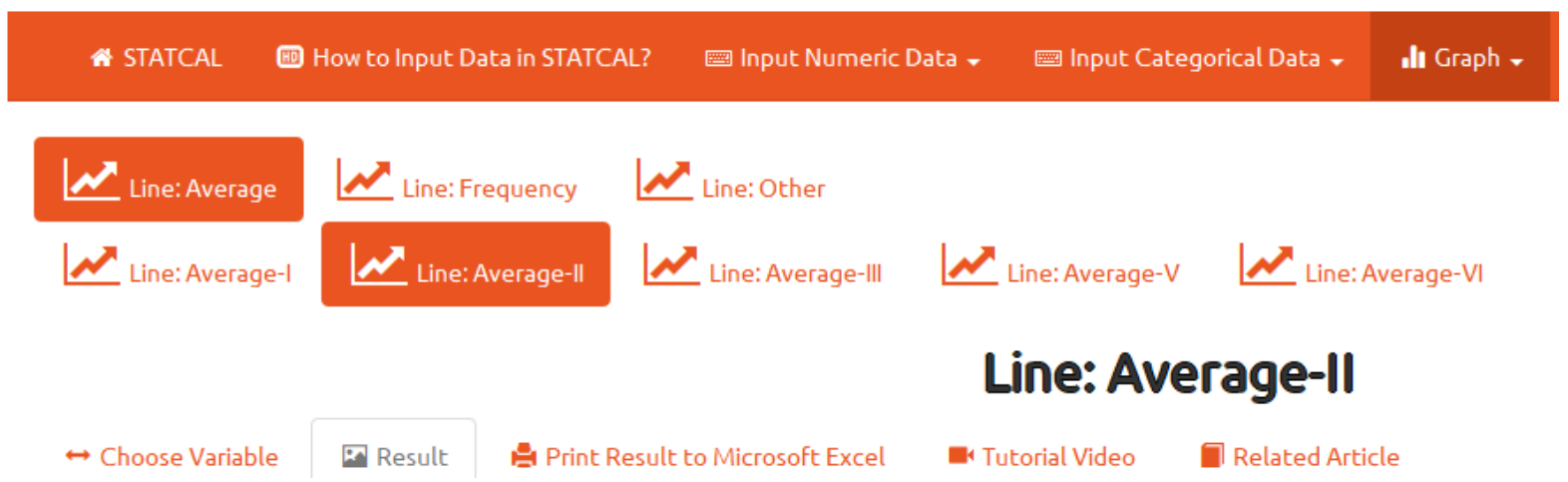

Gambar 1.3 Menu Line: Average-II

Langkah pertama adalah input data pada Tabel 1.1 ke dalam STATCAL seperti pada Gambar 1.4 (input data numerik) dan Gambar 1.5 (input data kategori). Selanjutnya kita akan mengakses menu Line: Average-II dengan memilih Graph => Line => Line: Average => Line: AverageII (Gambar 1.6). 


\section{A STATCAL 四 How to Input Data in STATCAL? 四 Input Numeric Data v 回 Input Categorical Data v}

\section{Numeric Data}

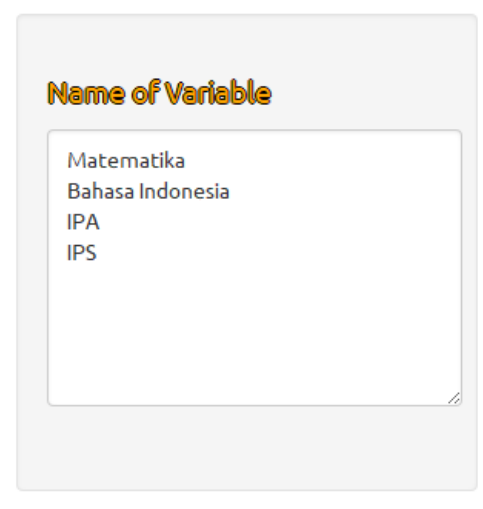

\section{Selt Nunober of Colunono}

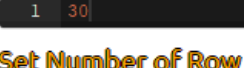

\section{Selt Nundoer of Rom}

\begin{tabular}{|c|c|c|c|c|c|c|c|c|}
\hline 1 100 & & & & & & \\
\hline & V1 & V2 & V3 & V4 & V5 & V6 & V7 & V8 \\
\hline 1 & 65.00 & 71.00 & 65.00 & 65.00 & & & & \\
\hline 2 & 66.00 & 72.00 & 67.00 & 66.00 & & & & \\
\hline 3 & 67.00 & 77.00 & 54.00 & 67.00 & & & & \\
\hline 4 & 65.00 & 73.00 & 56.00 & 64.00 & & & & \\
\hline 5 & 64.00 & 73.00 & 75.00 & 65.00 & & & & \\
\hline 6 & 71.00 & 85.00 & 76.00 & 85.00 & & & & \\
\hline 7 & 70.00 & 88.00 & 77.00 & 87.00 & & & & \\
\hline 8 & 74.00 & 86.00 & 87.00 & 77.00 & & & & \\
\hline 9 & 77.00 & 89.00 & 87.00 & 87.00 & & & & \\
\hline 10 & 74.00 & 86.00 & 65.00 & 76.00 & & & & \\
\hline & & & & & & & \\
\hline
\end{tabular}

Gambar 1.4 Input Data Numerik

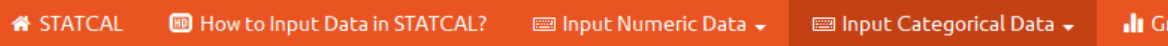

Input Categorical Data

\section{Categorical Data}

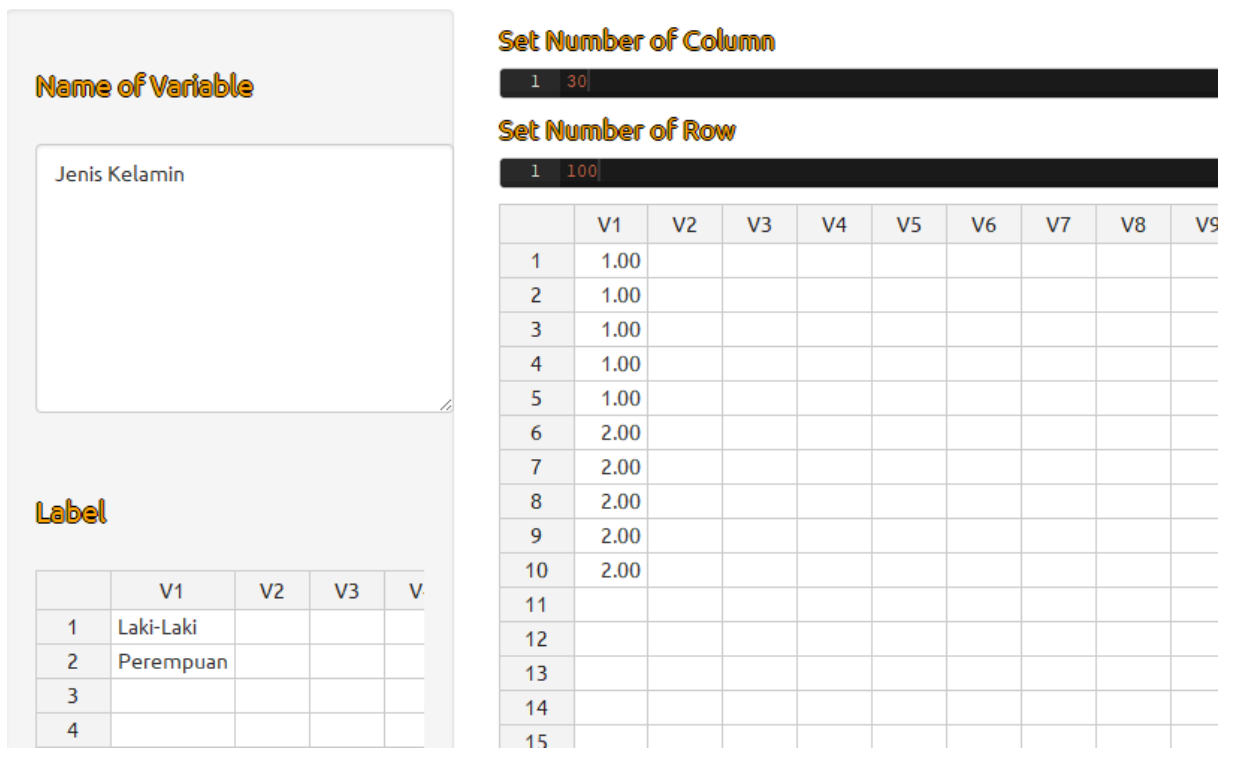

Gambar 1.5 Input Data Kategori 


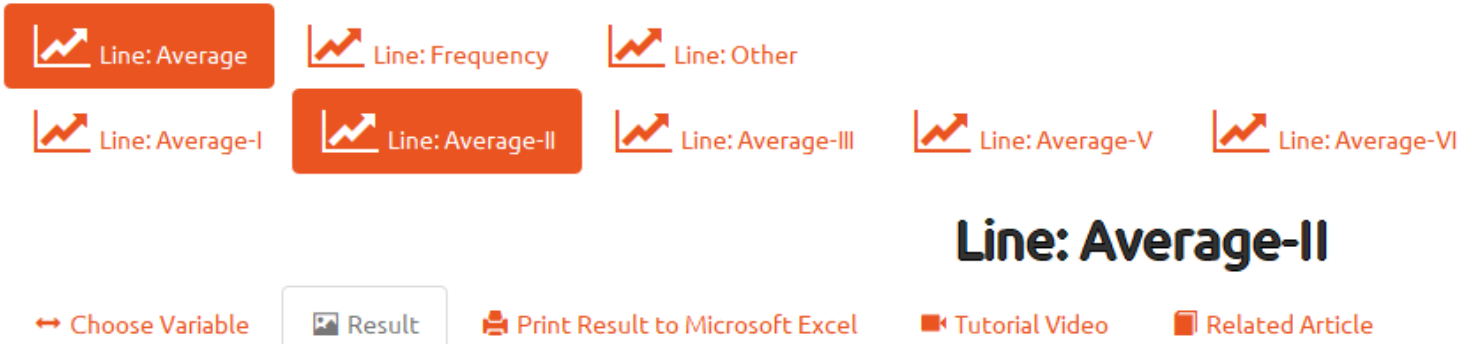

Gambar 1.6 Menu Line: Average-II

Pada Gambar 1.7:

$\Rightarrow$ Bagian Choose Numeric Variable (Multiple Choices), pindahkan seluruh variabel ke kotak sebelah kanan.

$\Rightarrow$ Bagian Choose Categorical Variable (Single Choice), pindahkan variabel jenis kelamin ke kotak sebelah kanan.

\section{LIne: Average-II}

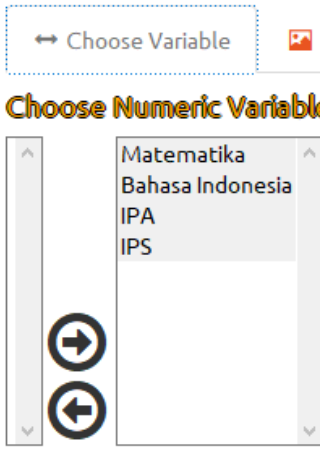

블 Print Result to Microsoft Excel 분 Tul

Choose Categorical Variable (Single Choice)

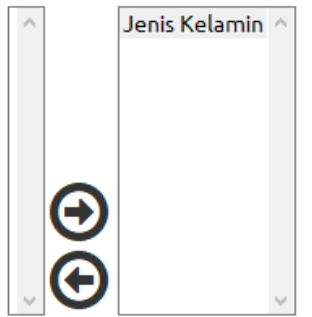

\section{Perhatikan bahwa "Single Choices" berarti Anda} dapat memasukkan variabel ke kotak sebelah kanan, hanya 1 variabel.

Gambar 1.7 Pemilihan Variabel 
Gambar 1.8 disajikan grafik garis rata-rata.

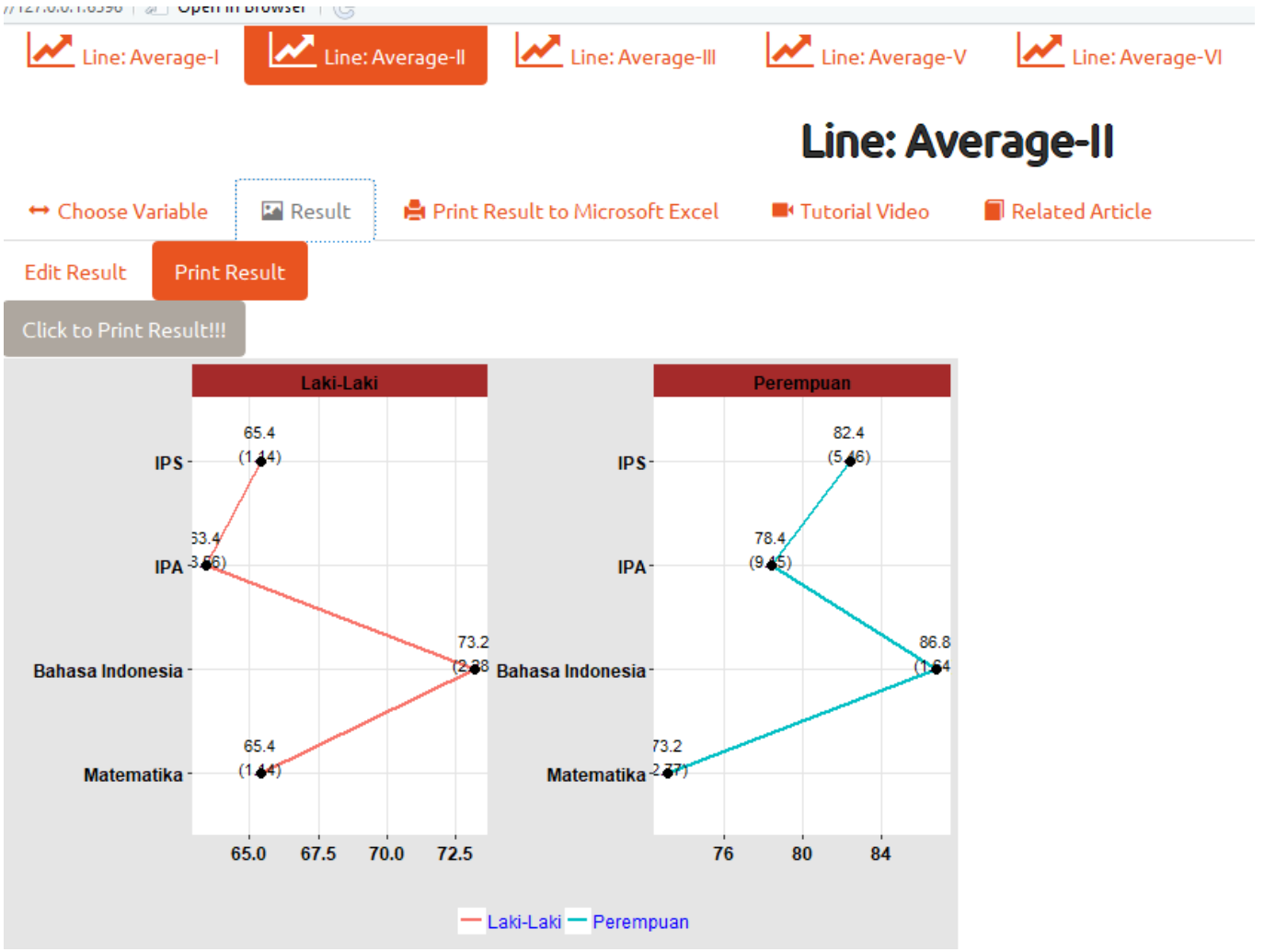

Gambar 1.8 Grafik Garis Rata-Rata 


\section{Mengolah Data dengan}

Program Aplikasi Statistika

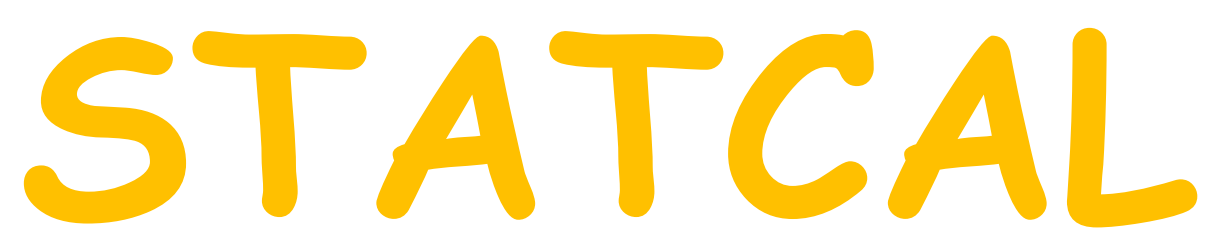

Membuat Grafik Garis Rata-Rata dengan Menu

Line: Average-III

Oleh Prana Ugiana Gio

Founder \& CEO STATCAL

Created by Prana Ugiana Gio \& Rezzy Eko Caraka

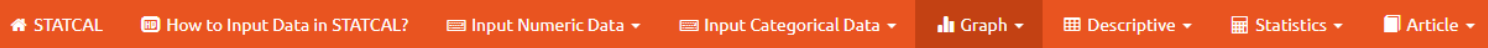

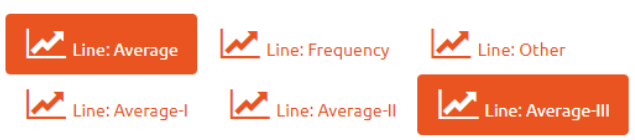

Line: Average-III
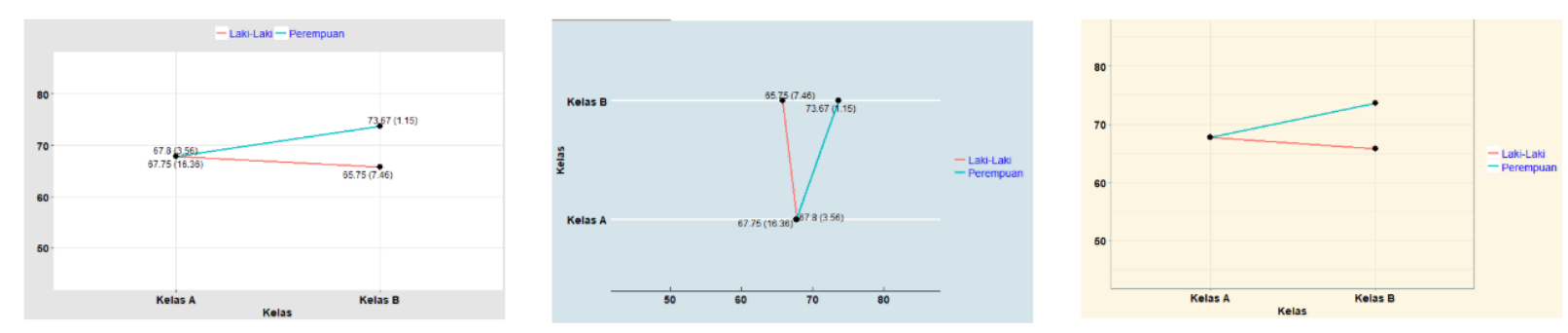
Misalkan diberikan data nilai ujian matematika berdasarkan jenis kelamin dan kelas (Tabel 1.1).

Tabel 1.1 Data Nilai Ujian Matematika berdasarkan Jenis Kelamin dan Kelas (Data Fiktif)

\begin{tabular}{|c|c|c|c|}
\hline Nama & Jenis Kelamin & Kelas & Nilai Matematika \\
\hline Andi & 1 & 1 & 65 \\
\hline Budi & 1 & 1 & 66 \\
\hline Ugi & 1 & 1 & 67 \\
\hline Egi & 1 & 1 & 74 \\
\hline Toni & 1 & 1 & 67 \\
\hline Tarno & 1 & 2 & 57 \\
\hline Geri & 1 & 2 & 64 \\
\hline Ganda & 1 & 2 & 75 \\
\hline Darmo & 1 & 2 & 67 \\
\hline Fitri & 2 & 1 & 83 \\
\hline Intan & 2 & 1 & 45 \\
\hline Sari & 2 & 1 & 75 \\
\hline Suci & 2 & 1 & 68 \\
\hline Rini & 2 & 2 & 73 \\
\hline Rina & 2 & 2 & 75 \\
\hline Fivi & 2 & 2 & 73 \\
\hline
\end{tabular}

\begin{tabular}{|c|c|c|}
\hline Angka & Jenis Kelamin & Kelas \\
\hline 1 & Laki-Laki & Kelas A \\
\hline 2 & Perempuan & Kelas B \\
\hline
\end{tabular}

Berdasarkan data pada Tabel 1.1, diketahui siswa yang bernama Ugi, dengan jenis kelamin lakilaki, kelas A, memperoleh nilai matematika 67. Dari data pada Tabel 1.1, disajikan grafik garis rata-rata seperti pada Gambar 1.1 . 


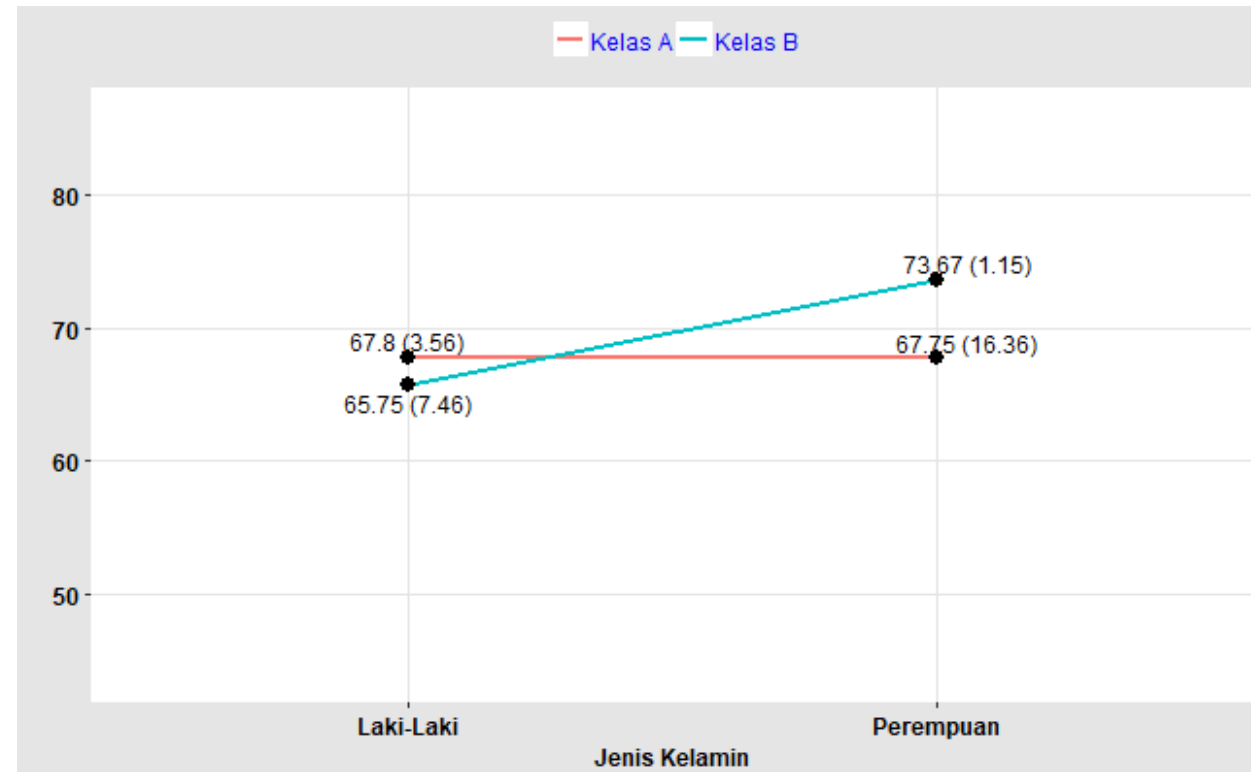

Gambar 1.1 Grafik Garis Rata-Rata

Berdasarkan grafik garis rata-rata pada Gambar 1.1, diketahui:

$\Rightarrow$ Rata-rata nilai matematika laki-laki kelas A adalah 67,8, dengan standar deviasi 3,56. Sementara rata-rata nilai matematika perempuan kelas A adalah 67,75, dengan standar deviasi 16,36 .

$\Rightarrow$ Rata-rata nilai matematika laki-laki kelas B adalah 65,75, dengan standar deviasi 7,46. Sementara rata-rata nilai matematika perempuan kelas B adalah 73,67, dengan standar deviasi 1,15 .

Untuk membuat grafik garis rata-rata pada Gambar 1.1, kita akan menggunakan menu Line: Average-III (Line 1.2). 


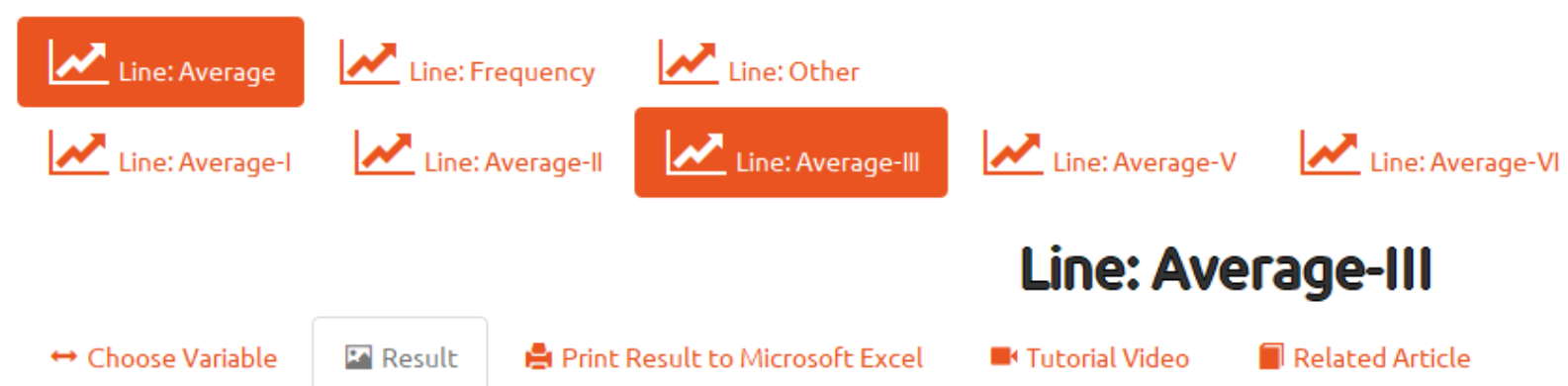

Gambar 1.2 Menu Line: Average-III

Langkah pertama adalah input data pada Tabel 1.1 ke dalam STATCAL seperti pada Gambar 1.3 (input data numerik) dan Gambar 1.4 (input data kategori). Selanjutnya kita akan mengakses menu Line: Average-III dengan memilih Graph $\Rightarrow$ Line $\Rightarrow$ Line: Average $=>$ Line: Average-III (Gambar 1.5).

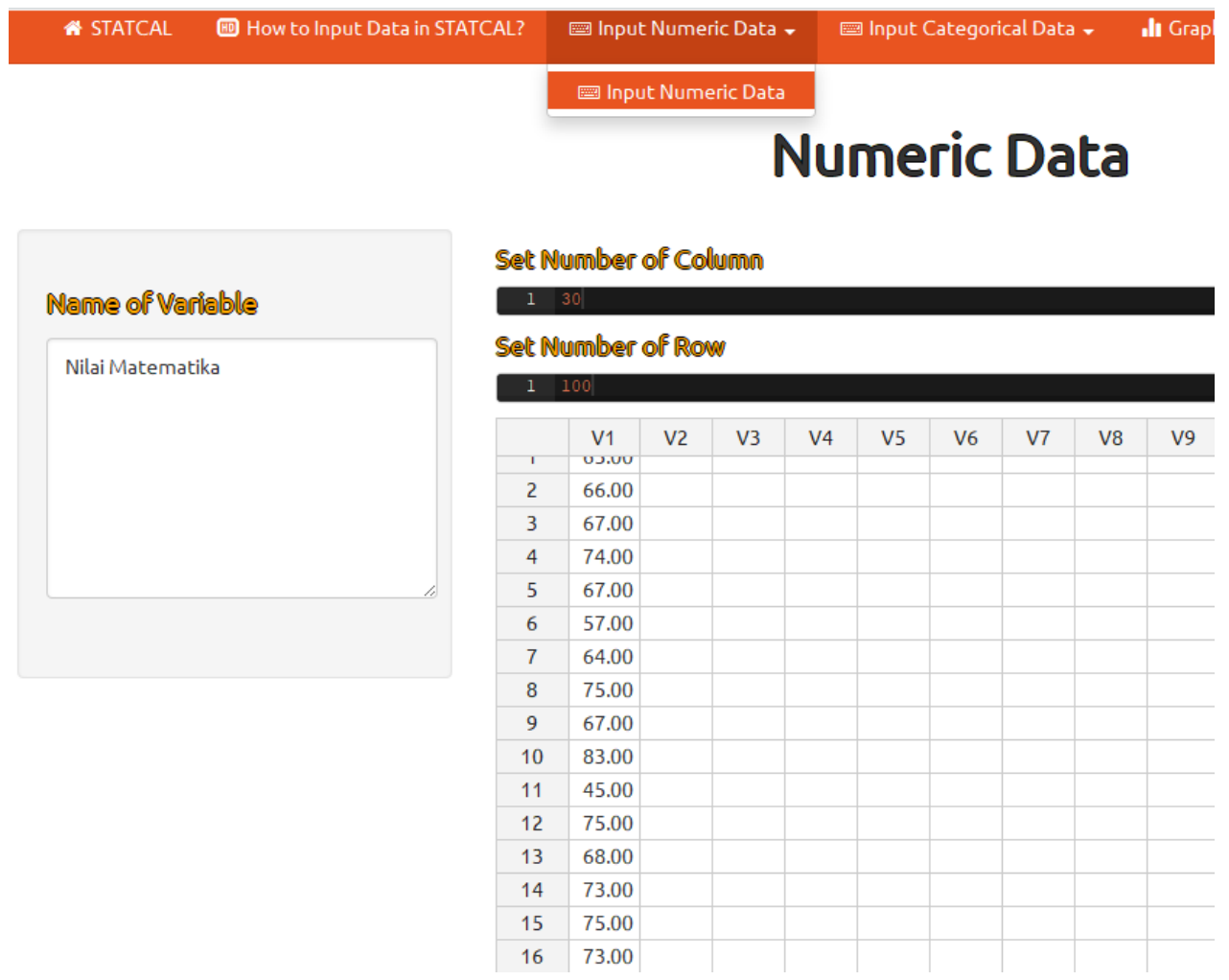

Gambar 1.3 Input Data Numerik 


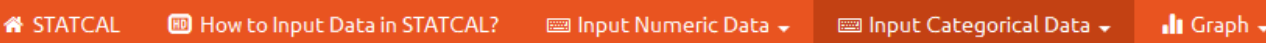

Input Categorical Data

\section{Categorical Data}

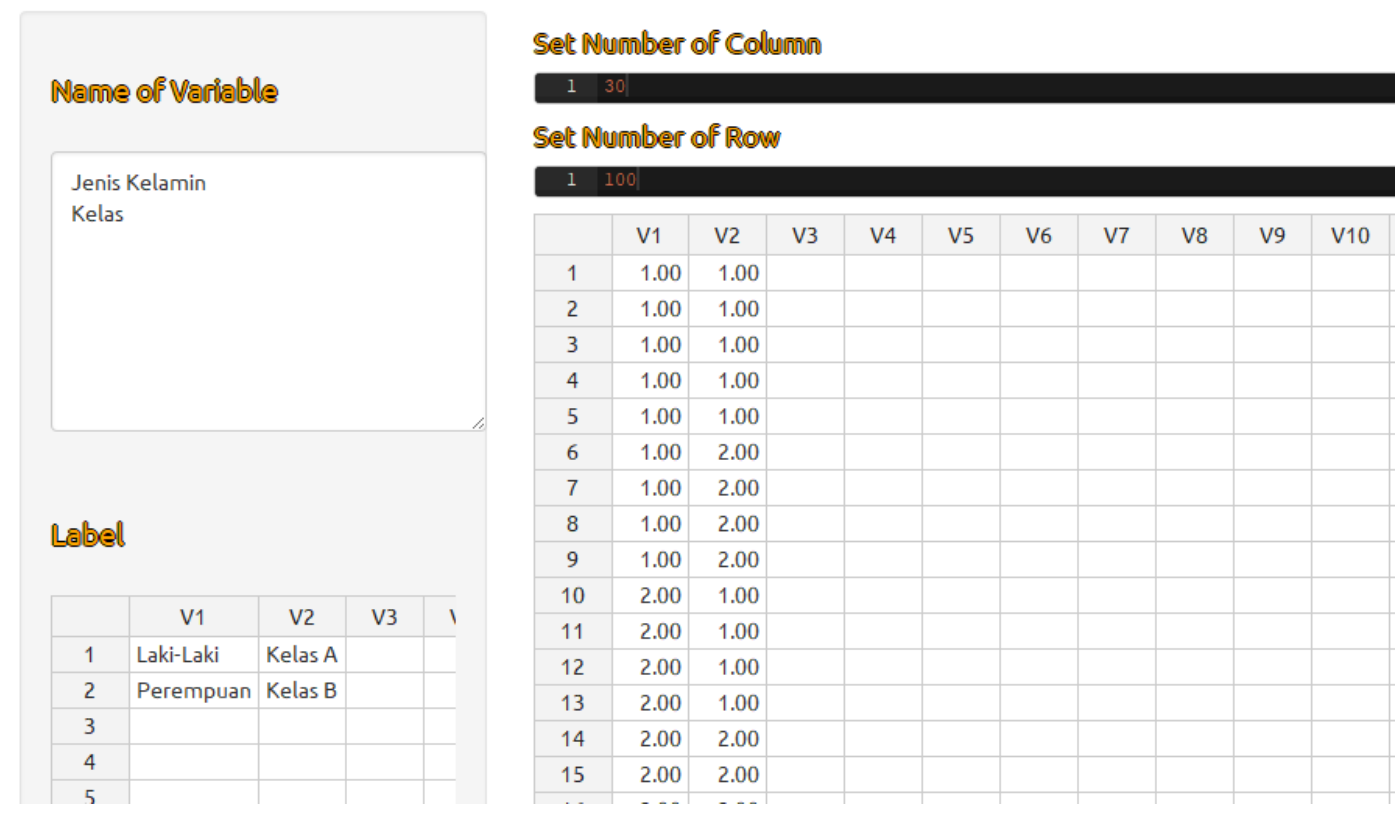

Gambar 1.4 Input Data Kategori
$\underline{N}$ Line: Average
Line: Frequency
Line: Other
$\widetilde{N}$ Line: Average-1
$\mathcal{N}$ Line: Average-lI
Line: Average-III

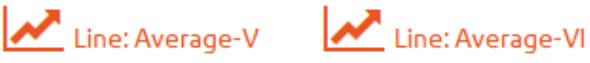
Line: Average-III
$\leftrightarrow$ Choose Variable Result 복 Print Result to Microsoft Excel

Gambar 1.5 Menu Line: Average-III

Perhatikan Gambar 1.6. Lakukan pemilihan variabel seperti pada Gambar 1.6. 
Choose Variable Result

Choose Nunieric Variable (Single Choice) (V-Axis)

Nilai Matematika

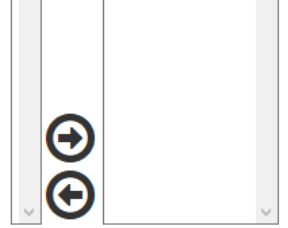

Choose Categorical Variable (Single Choice) (X-Axis)

Kelas ^ Jenis Kelamin ^

$\Theta$

$\odot$
Choose Categorical Variable (Single Choice) (X-Axis)

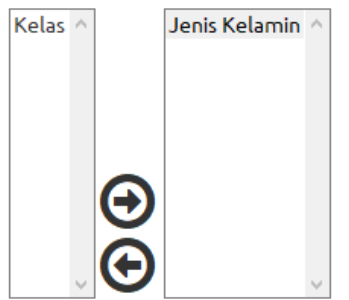

Choose Categorical Variable (Single Choice) (Colunon)

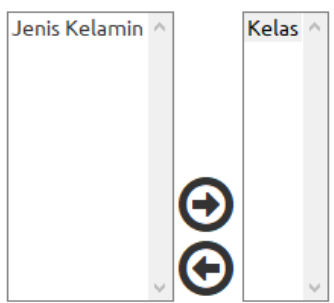

Gambar 1.6 Pemilihan Variabel

Gambar 1.7 disajikan grafik garis rata-rata.

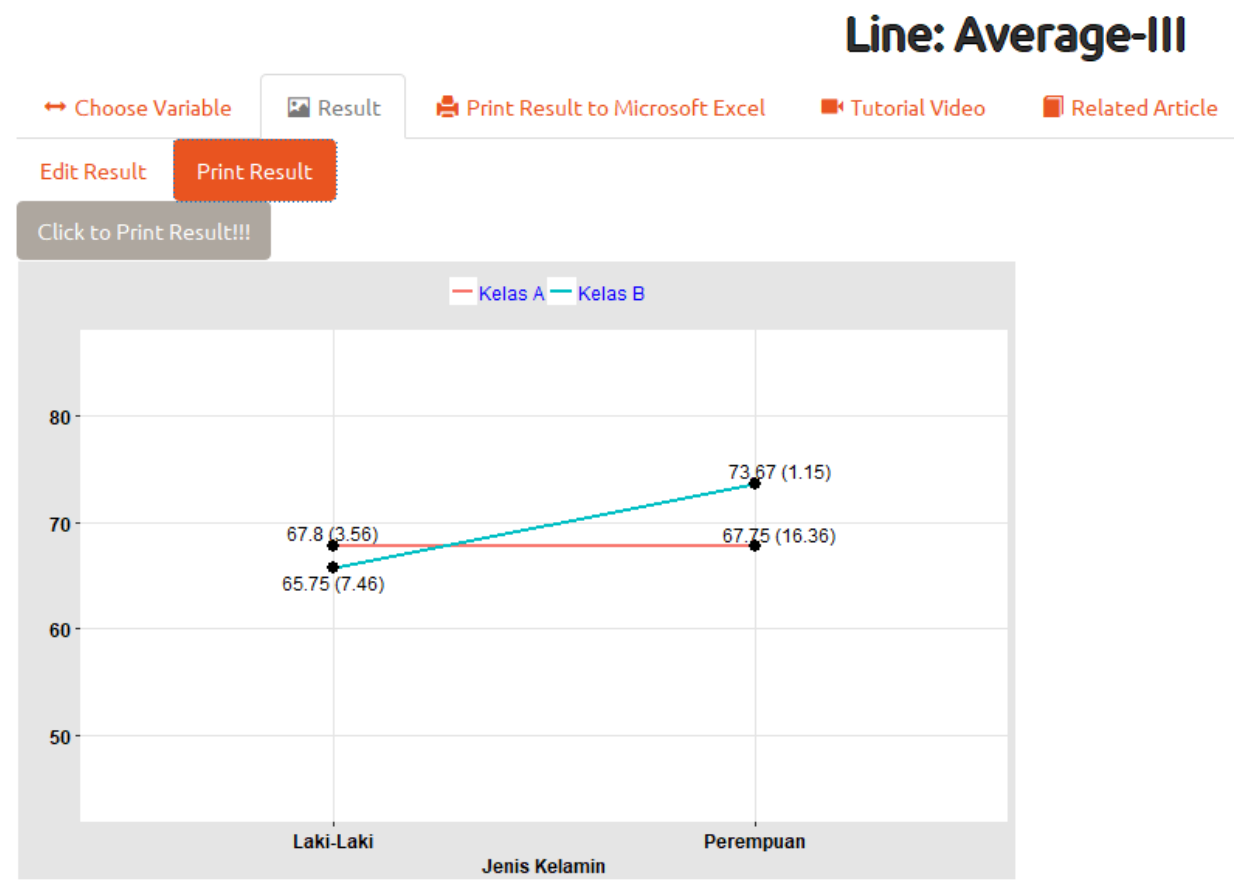

Gambar 1.7 Grafik Garis Rata-Rata 


\section{Mengolah Data dengan} Program Aplikasi Statistika

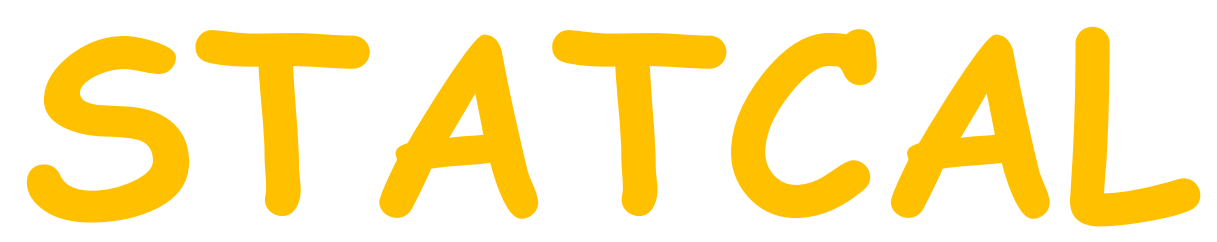

Membuat Grafik Garis Frekuensi dengan Menu

$$
\text { Line: Frequency-I }
$$

Oleh Prana Ugiana Gio

Founder \& CEO STATCAL

Created by Prana Ugiana Gio \& Rezzy Eko Caraka

Line: Frequency-I
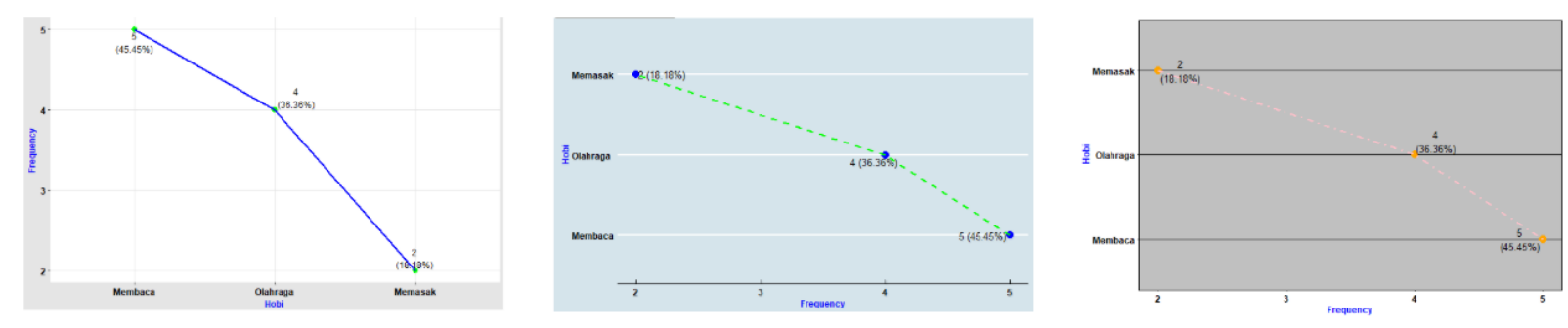
Misalkan diberikan data hobi dari 11 responden (Tabel 1.1).

Tabel 1.1 Data Hobi dari 11 Responden (Data Fiktif)

\begin{tabular}{|c|c|}
\hline Nama & Hobi \\
\hline Ugi & 1 \\
\hline Egi & 2 \\
\hline Andi & 3 \\
\hline Edi & 1 \\
\hline Rina & 1 \\
\hline Rini & 2 \\
\hline Suci & 2 \\
\hline Ani & 1 \\
\hline Fitri & 1 \\
\hline Tini & 2 \\
\hline Andi & 3 \\
\hline
\end{tabular}

\begin{tabular}{|c|c|}
\hline Angka & Hobi \\
\hline 1 & Membaca \\
\hline 2 & Olahraga \\
\hline 3 & Memasak \\
\hline
\end{tabular}

Berdasarkan data pada Tabel 1.1, diketahui responden yang bernama Ugi memiliki hobi membaca, responden yang bernama Egi memiliki hobi olahraga, dan seterusnya. Dari data pada Tabel 1.1, disajikan grafik garis frekuensi seperti pada Gambar 1.1.

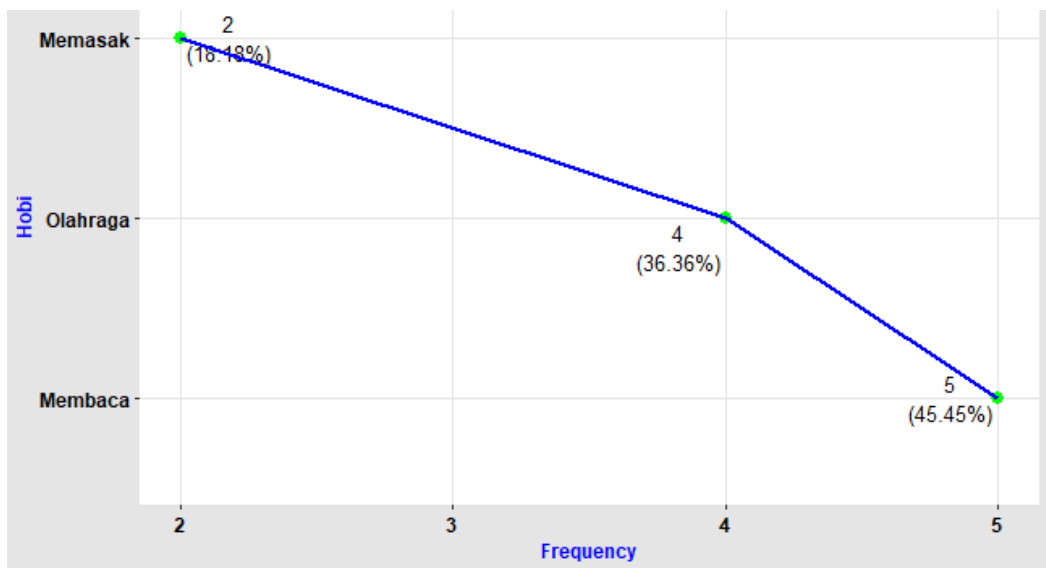

Gambar 1.1 Grafik Garis Frekuensi 
Berdasarkan grafik garis frekuensi pada Gambar 1.1, diketahui:

$\Rightarrow$ Jumlah responden dengan hobi membaca sebanyak $5(45,45 \%)$ responden.

$\Rightarrow$ Jumlah responden dengan hobi olahraga sebanyak $4(36,36 \%)$ responden.

$\Rightarrow$ Jumlah responden dengan hobi memasak sebanyak $2(18,18 \%)$ responden.

Untuk membuat grafik garis frekuensi pada Gambar 1.1, kita akan menggunakan menu Line: Frequency-I (Gambar 1.2).

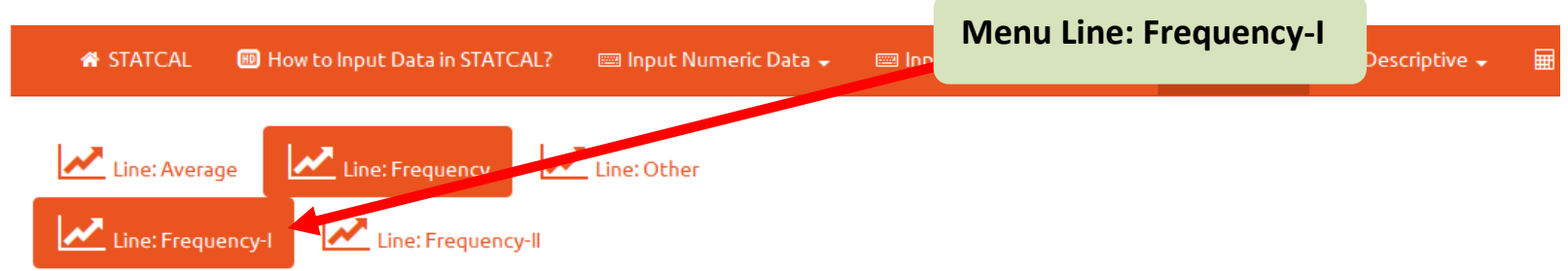

\section{Line: Frequency-I}

\section{Gambar 1.2 Menu Line: Frequency-I}
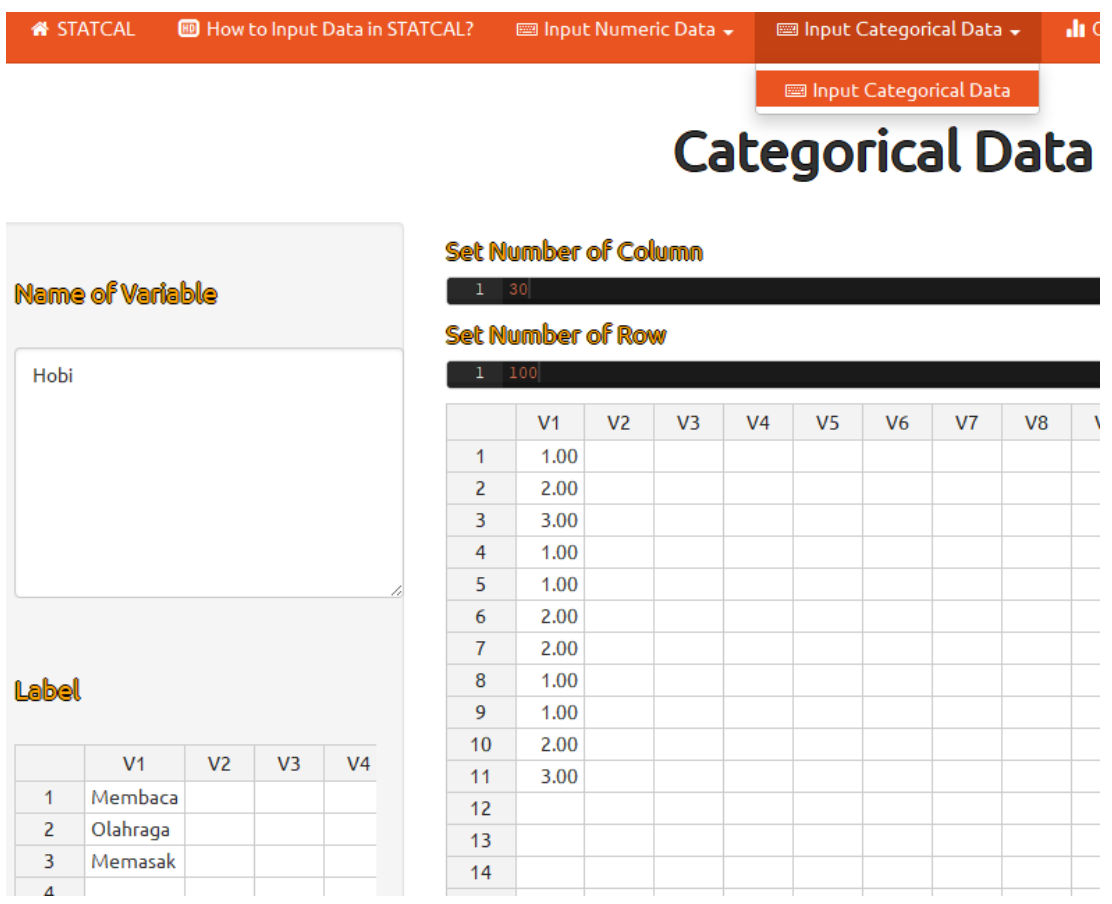

Gambar 1.3 Input Data Kategori pada Bagian Input Categorical Data 


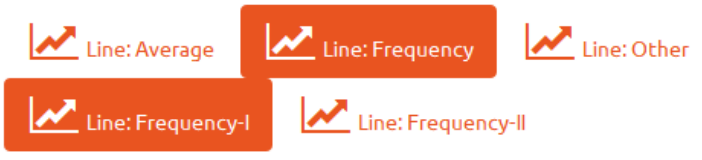

\section{Line: Frequency-I}

\section{Gambar 1.4 Menu Line: Frequency-I}

Langkah pertama adalah input data pada Tabel 1.1 ke dalam STATCAL seperti pada Gambar 1.3. Perhatikan bahwa data diinput pada bagian Input Categorical Data. Selanjutnya kita akan mengakses menu Line: Frequency-I dengan memilih Graph $=>$ Line $=>$ Line: Frequency $=>$ Line: Frequency-I (Gambar 1.4). Pada Gambar 1.5, pindahkan variabel hobi ke kotak sebelah kanan.

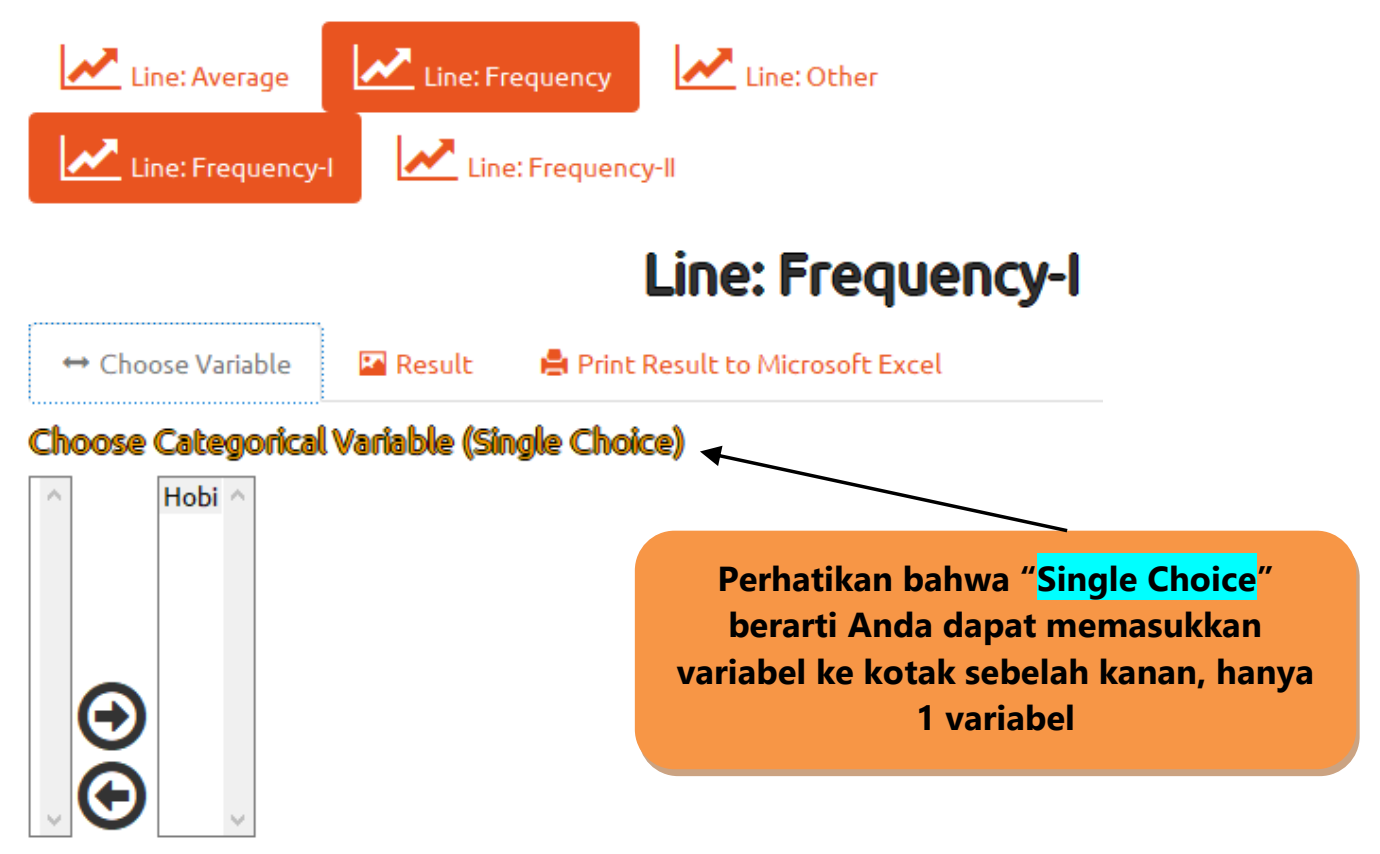

Gambar 1.5 Pemilihan Variabel 
Gambar 1.6 disajikan grafik garis frekuensi.

\section{Line: Frequency-I}

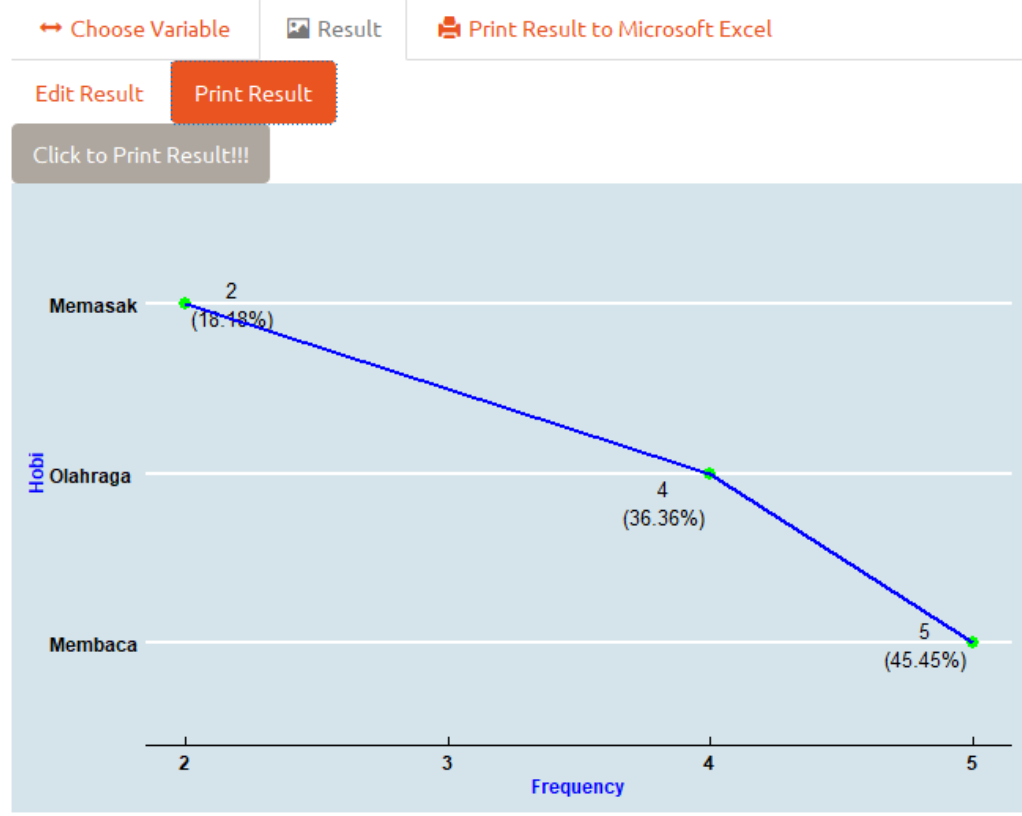

Gambar 1.6 Grafik Garis Frekuensi 


\section{Mengolah Data dengan}

Program Aplikasi Statistika

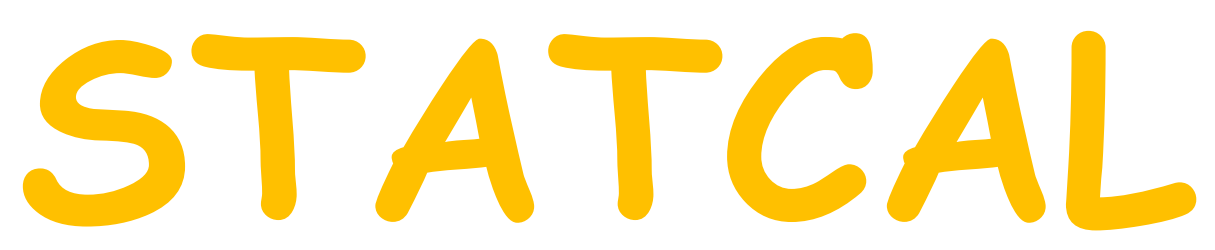

Membuat Grafik Garis Frekuensi dengan Menu

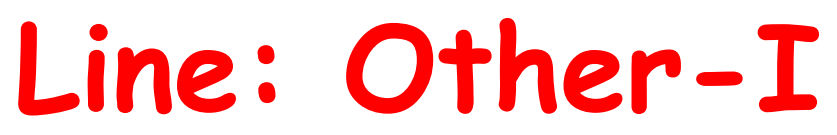

\section{Oleh Prana Ugiana Gio}

\section{Founder \& CEO STATCAL}

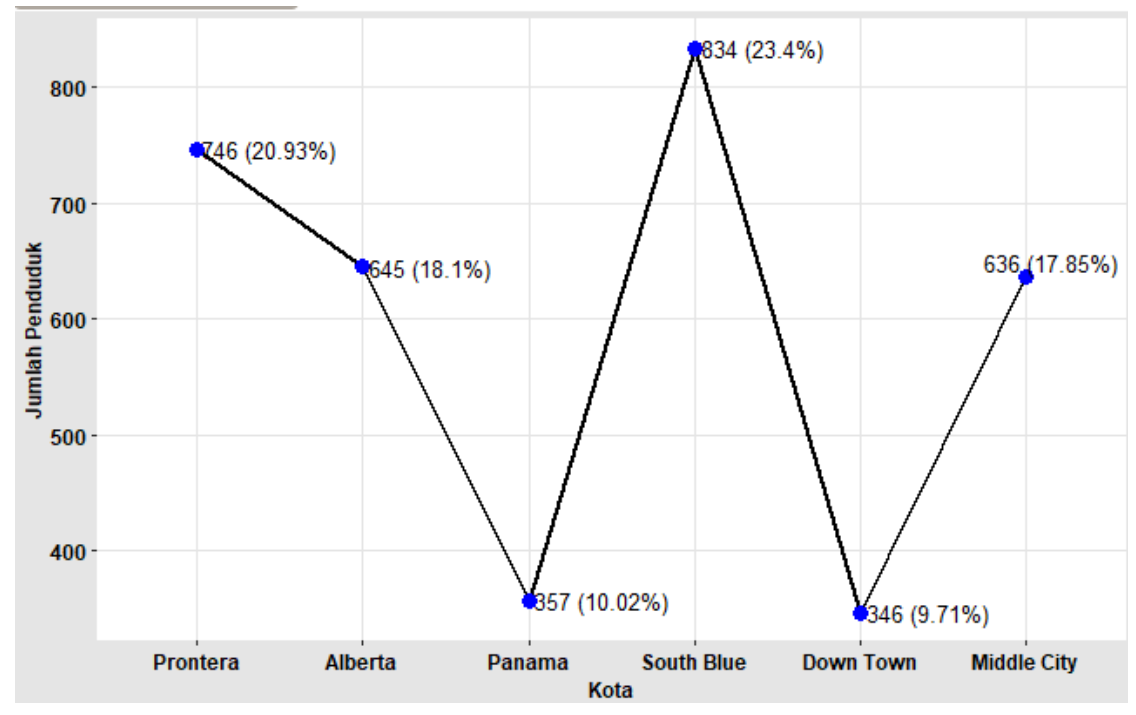


Misalkan diberikan data jumlah penduduk berdasarkan 6 kota (Tabel 1.1).

Tabel 1.1 Data Jumlah Siswa berdasarkan Kelas dan Jenis Kelamin (Data Fiktif)

\begin{tabular}{|c|c|c|}
\hline Kota & Jumlah Penduduk & Persentase \\
\hline Prontera & 746 & 20.93 \\
\hline Alberta & 645 & 18.10 \\
\hline Panama & 357 & 10.02 \\
\hline South Blue & 834 & 23.40 \\
\hline Down Town & 346 & 9.71 \\
\hline Middle City & 636 & 17.85 \\
\hline Total & 3564 & 100 \\
\hline
\end{tabular}

Berdasarkan data pada Tabel 1.1, diketahui jumlah penduduk pada kota Prontera adalah 746 (20,93\%), jumlah penduduk pada kota Alberta adalah 645 (18,10\%). Dari data pada Tabel 1.1, disajikan grafik garis frekuensi seperti pada Gambar 1.1.

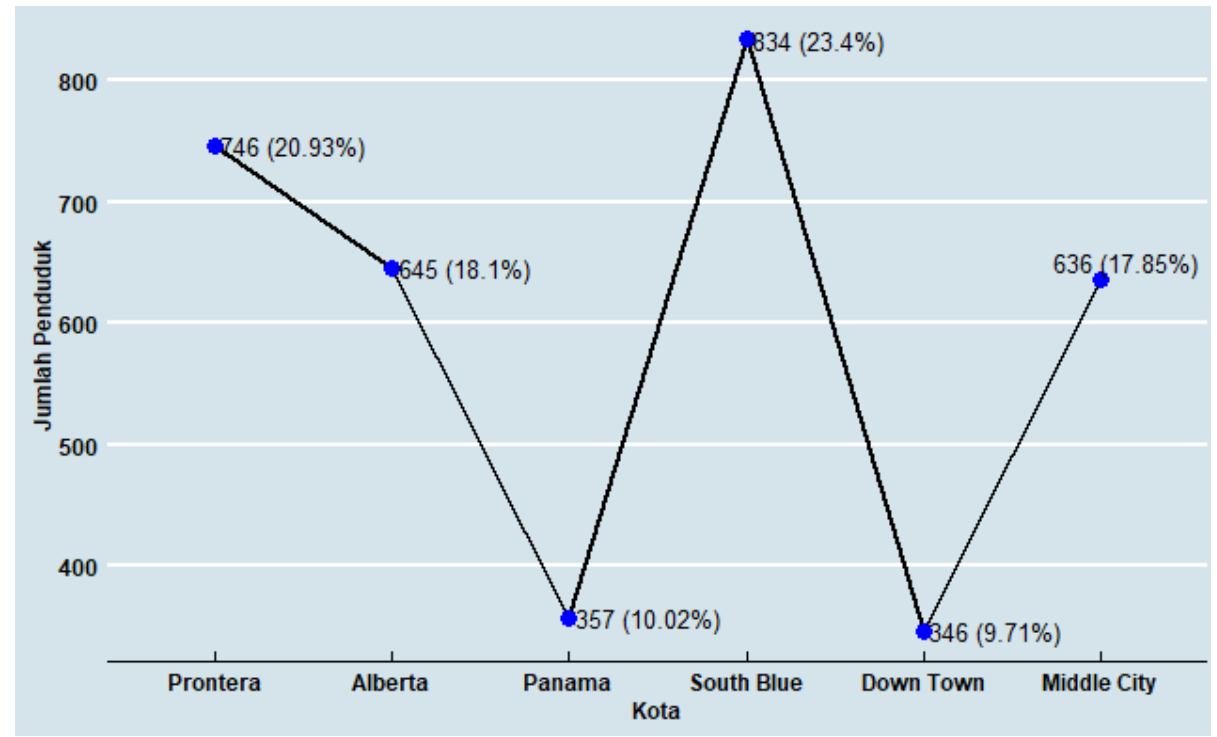

Gambar 1.1 Grafik Garis Frekuensi

Untuk membuat grafik garis frekuensi pada Gambar 1.1, kita akan menggunakan menu Line: Other-I (Gambar 1.2). 


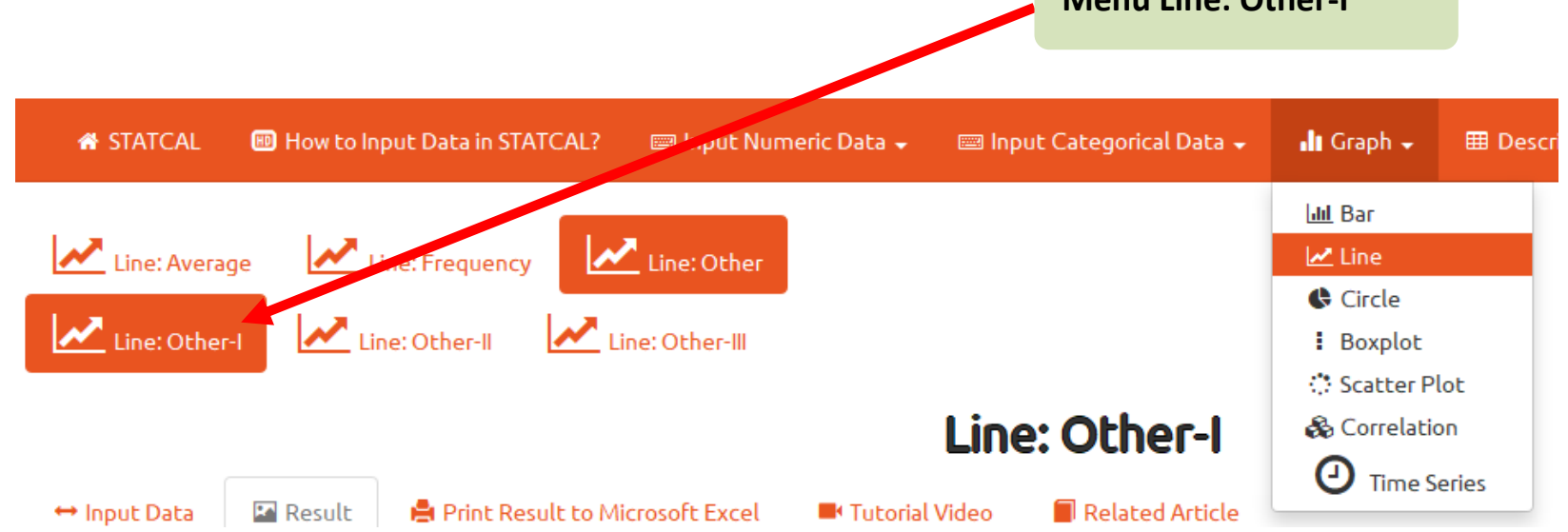

Gambar 1.2 Menu Line: Other-I

Untuk mengakses menu Line: Other-I, pilih Graph => Line => Line: Other => Line: Other-I (Gambar 1.2). Dengan menggunakan data pada Tabel 1.1, input data seperti pada Gambar 1.3.

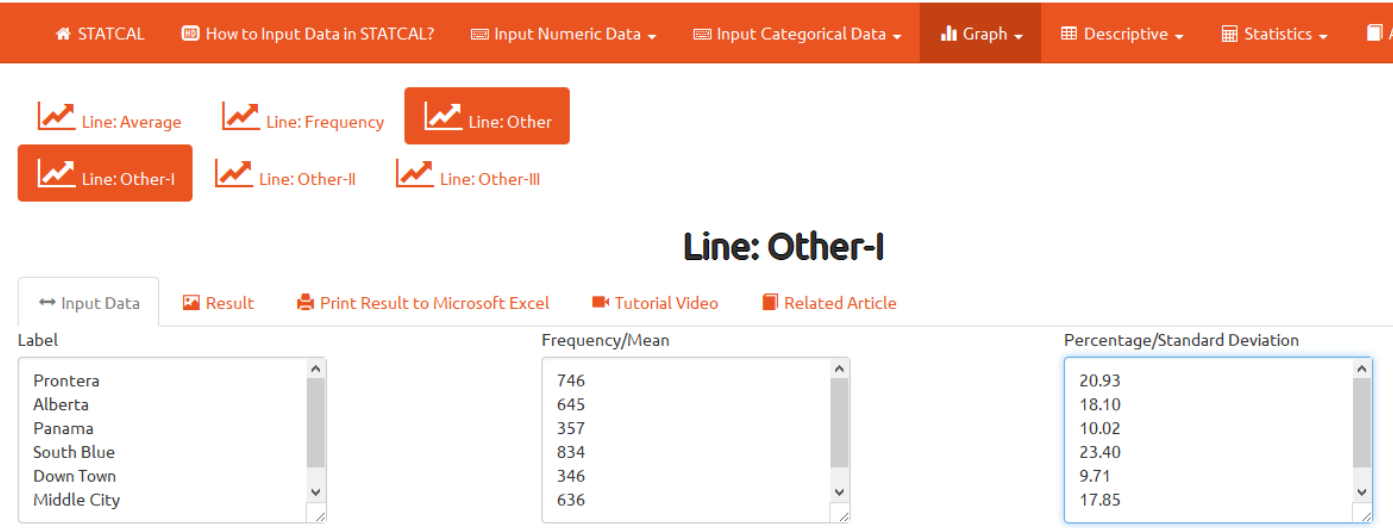

\section{Gambar 1.3 Input Data pada Menu Line: Other-I}

Hasil dari grafik garis frekuensi dapat dilihat pada bagian Result => Print Result (Gambar 1.4). 


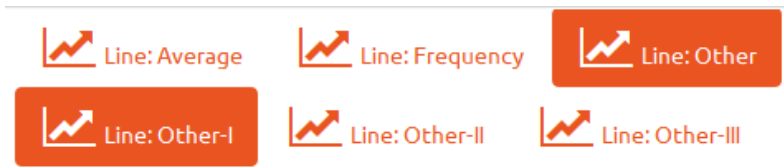

\section{Line: Other-I}

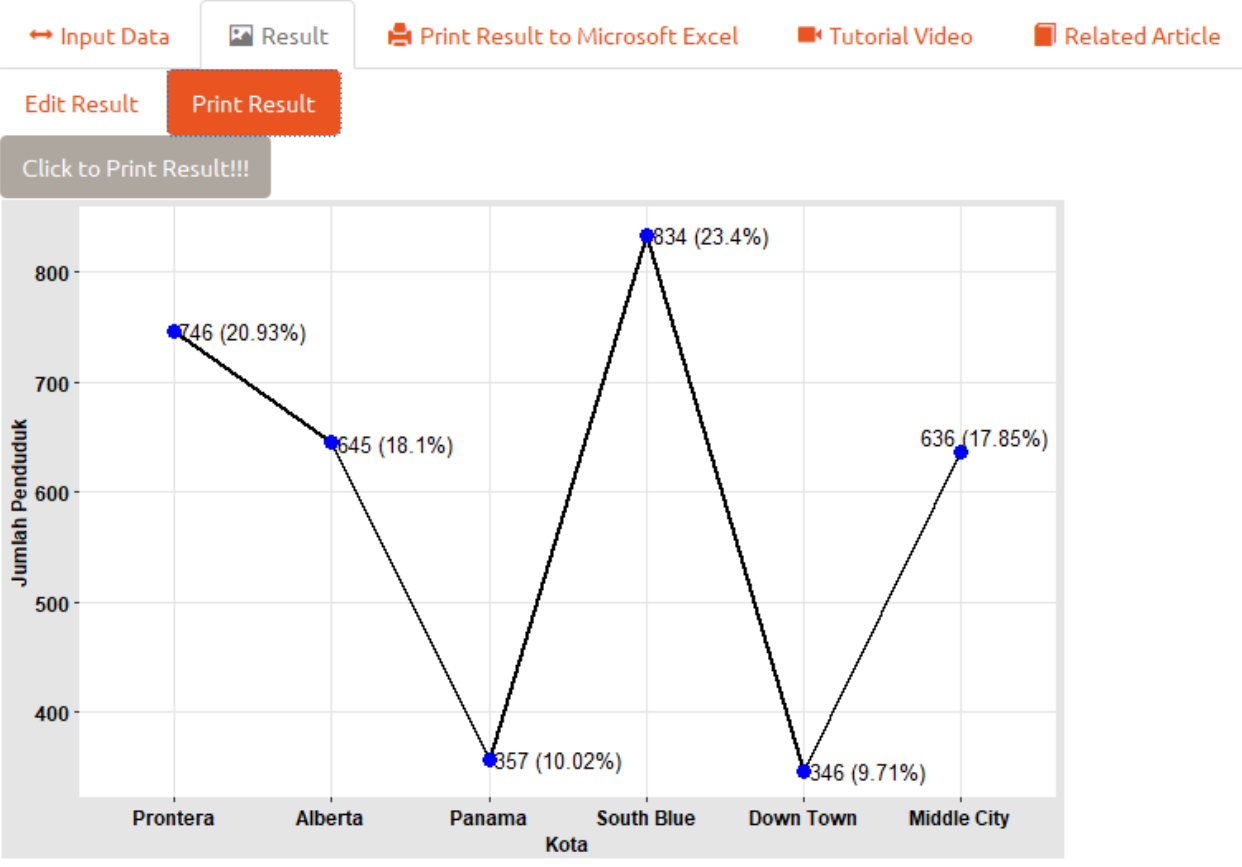

Gambar 1.4 Grafik Garis Frekuensi 


\section{Mengolah Data dengan} Program Aplikasi Statistika

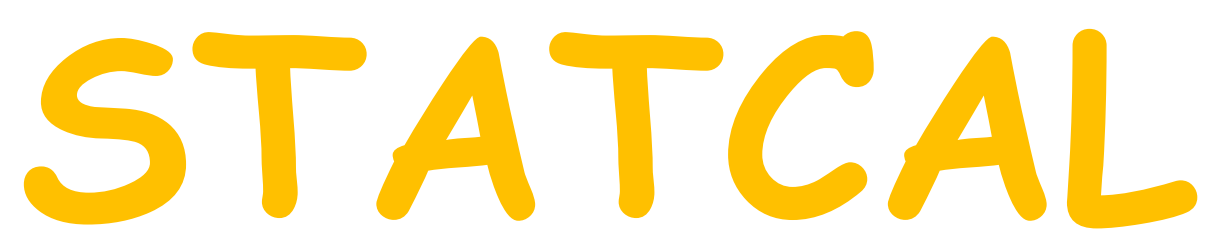

Membuat Grafik Garis Rata-Rata dengan Menu

$$
\text { Line: Other-I }
$$

\section{Oleh Prana Ugiana Gio}

Founder \& CEO STATCAL

Created by Prana Ugiana Gio \& Rezzy Eko Caraka

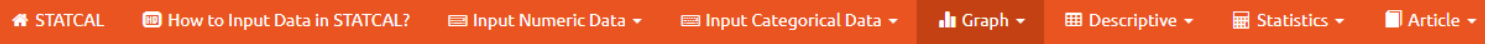

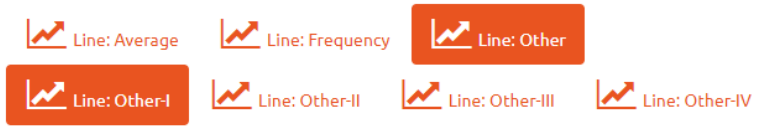

Line: Other-I
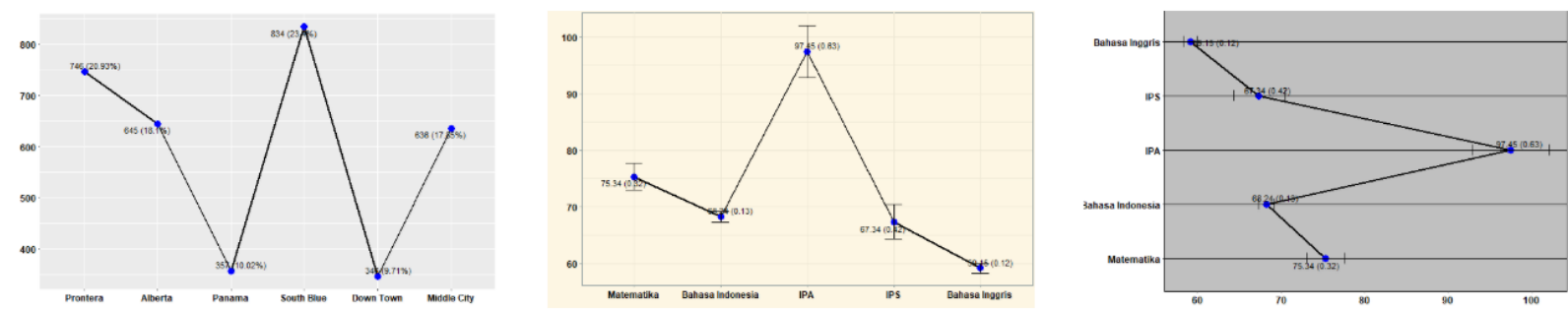
Misalkan diberikan data rata-rata dan standar deviasi berdasarkan pelajaran matematika, bahasa Indonesia, IPA, IPS dan bahasa Inggris (Tabel 1.1).

Tabel 1.1 Data Nilai Rata-Rata Pelajaran Matematika, Bahasa Indonesia, IPA, IPS dan Bahasa Inggris (Data Fiktif)

\begin{tabular}{|c|c|c|}
\hline Pelajaran & Rata-Rata & Standar Deviasi \\
\hline Matematika & 75.34 & 0.32 \\
\hline Bahasa Indonesia & 68.24 & 0.13 \\
\hline IPA & 97.45 & 0.63 \\
\hline IPS & 67.34 & 0.42 \\
\hline Bahasa Inggris & 59.15 & 0.12 \\
\hline
\end{tabular}

Berdasarkan data pada Tabel 1.1, diketahui rata-rata nilai matematika adalah 75,34, dengan standar deviasi 0,32, rata-rata nilai bahasa Indonesia adalah 68,24, dengan standar deviasi 0,13, dan seterusnya. Dari data pada Tabel 1.1, disajikan grafik garis rata-rata seperti pada Gambar 1.1.

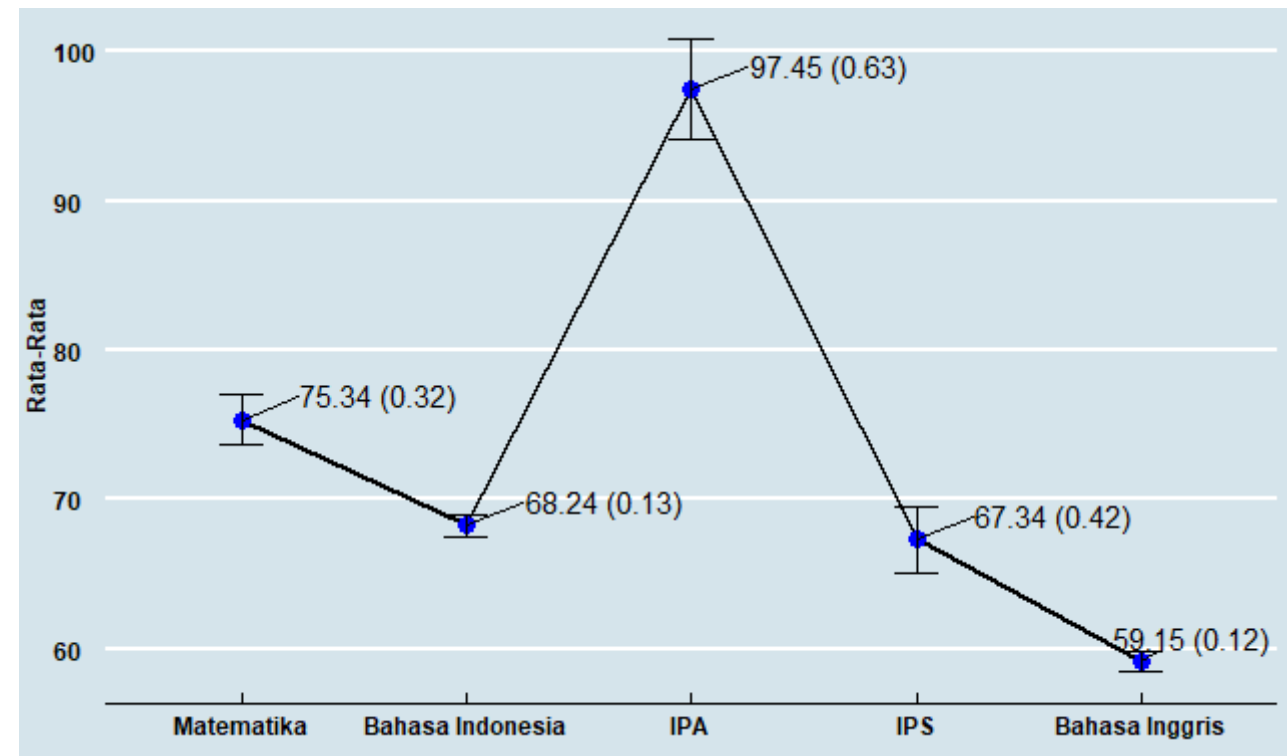

Gambar 1.1 Grafik Garis Rata-Rata 
Untuk membuat grafik garis rata-rata pada Gambar 1.1, kita akan menggunakan menu Line: Other-I (Gambar 1.2).

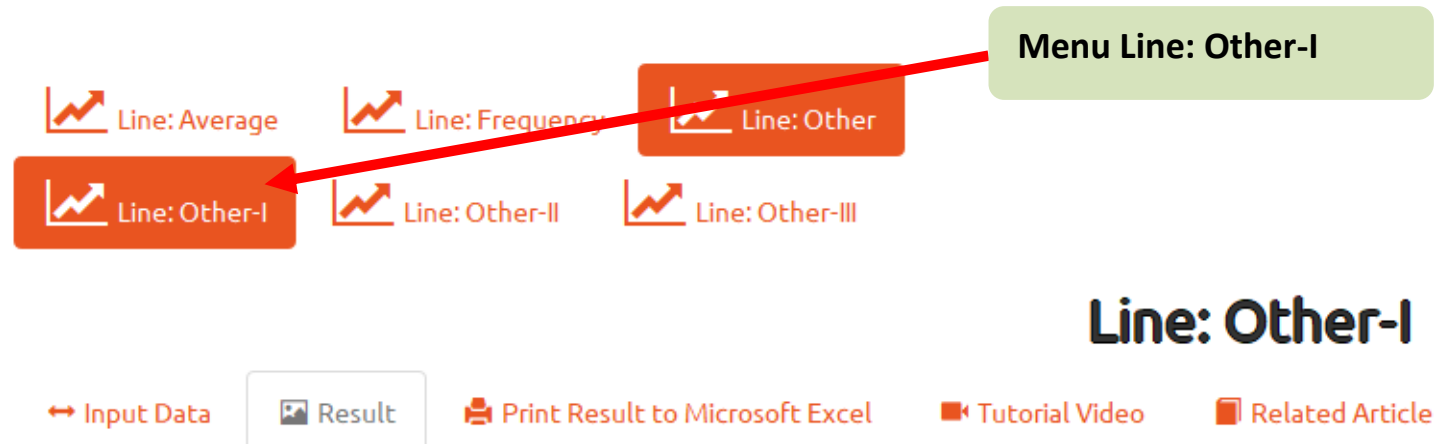

Gambar 1.2 Menu Line: Other-I

Untuk mengakses menu Line: Other-I, pilih Graph => Line => Line: Other => Line: Other-I

(Gambar 1.2). Dengan menggunakan data pada Tabel 1.1, input data seperti pada Gambar 1.3.

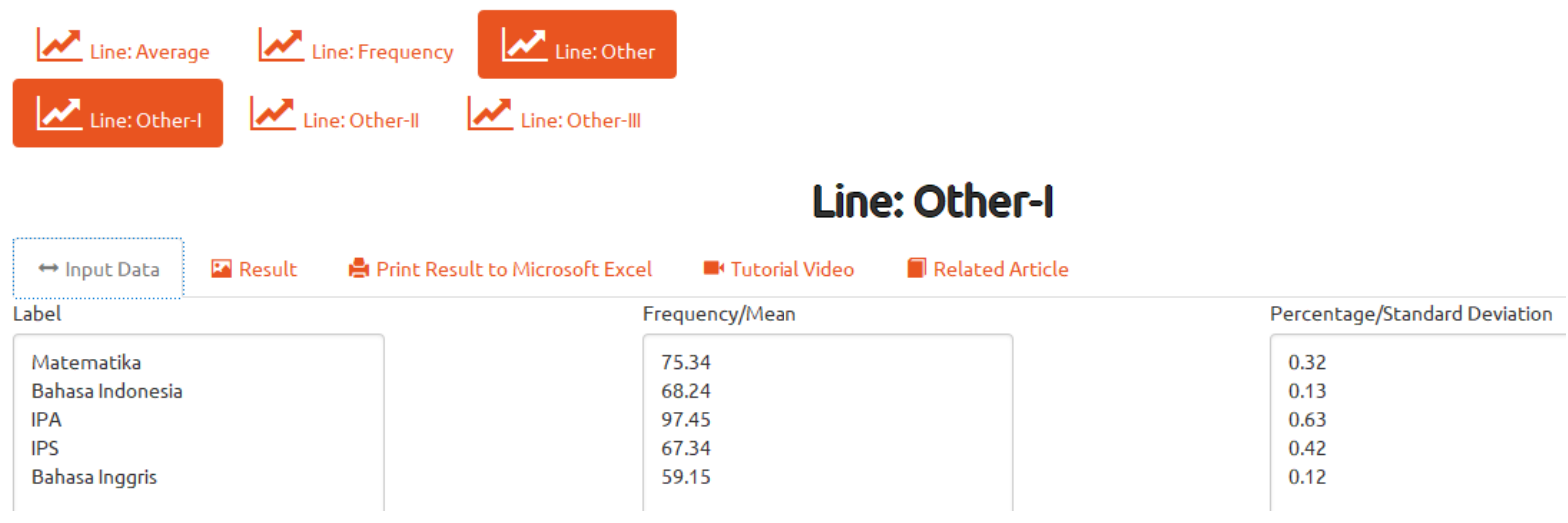

Gambar 1.3 Input Data pada Menu Line: Other-I

Hasil dari grafik garis rata-rata dapat dilihat pada bagian Result => Print Result (Gambar 1.4). 


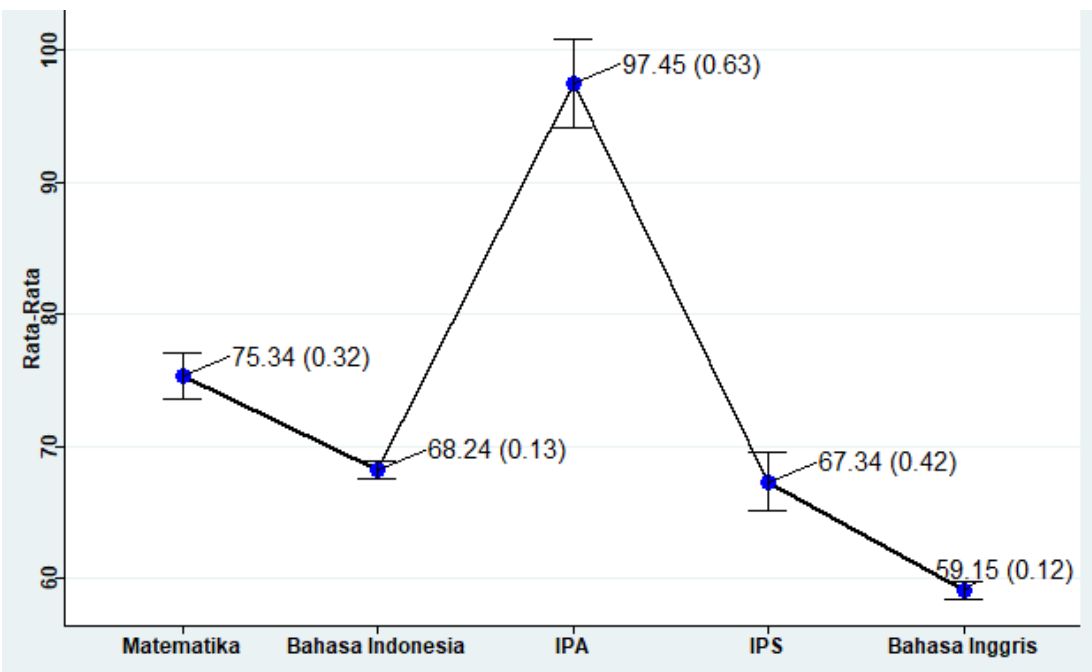

Gambar 1.4 Grafik Garis Rata-Rata 


\section{Mengolah Data dengan}

Program Aplikasi Statistika

Membuat Grafik Garis Frekuensi dengan Menu Line: Other-II

\section{Oleh Prana Ugiana Gio}

\section{Founder \& CEO STATCAL}

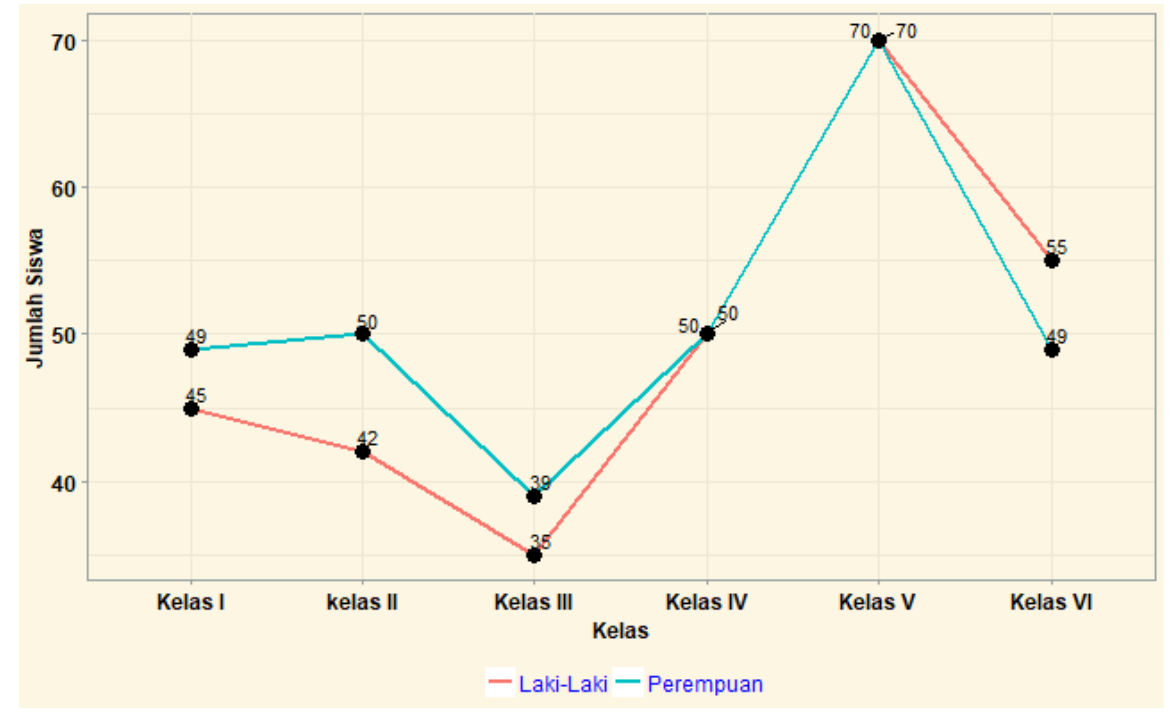


Misalkan diberikan data jumlah siswa berdasarkan kelas dan jenis kelamin (Tabel 1.1).

Tabel 1.1 Data Jumlah Siswa berdasarkan Kelas dan Jenis Kelamin (Data Fiktif)

\begin{tabular}{|c|c|c|}
\hline Kelas & Jenis Kelamin & Jumlah Siswa \\
\hline 1 & 1 & 45 \\
\hline 1 & 2 & 49 \\
\hline 2 & 1 & 42 \\
\hline 2 & 2 & 50 \\
\hline 3 & 1 & 35 \\
\hline 3 & 2 & 39 \\
\hline 4 & 1 & 50 \\
\hline 4 & 2 & 50 \\
\hline 5 & 1 & 70 \\
\hline 5 & 2 & 70 \\
\hline 6 & 1 & 55 \\
\hline 6 & 2 & 49 \\
\hline
\end{tabular}

\begin{tabular}{|c|c|c|}
\hline Angka & Kelas & Jenis Kelamin \\
\hline 1 & Kelas I & Laki-Laki \\
\hline 2 & kelas II & Perempuan \\
\hline 3 & Kelas III & \\
\hline 4 & Kelas IV & \\
\hline 5 & Kelas V & \\
\hline 6 & Kelas VI & \\
\hline
\end{tabular}

Berdasarkan data pada Tabel 1.1, diketahui jumlah siswa kelas I laki-laki sebanyak 45, jumlah siswa kelas I perempuan sebanyak 49, dan seterusnya. Dari data pada Tabel 1.1, disajikan grafik garis frekuensi seperti pada Gambar 1.1. 


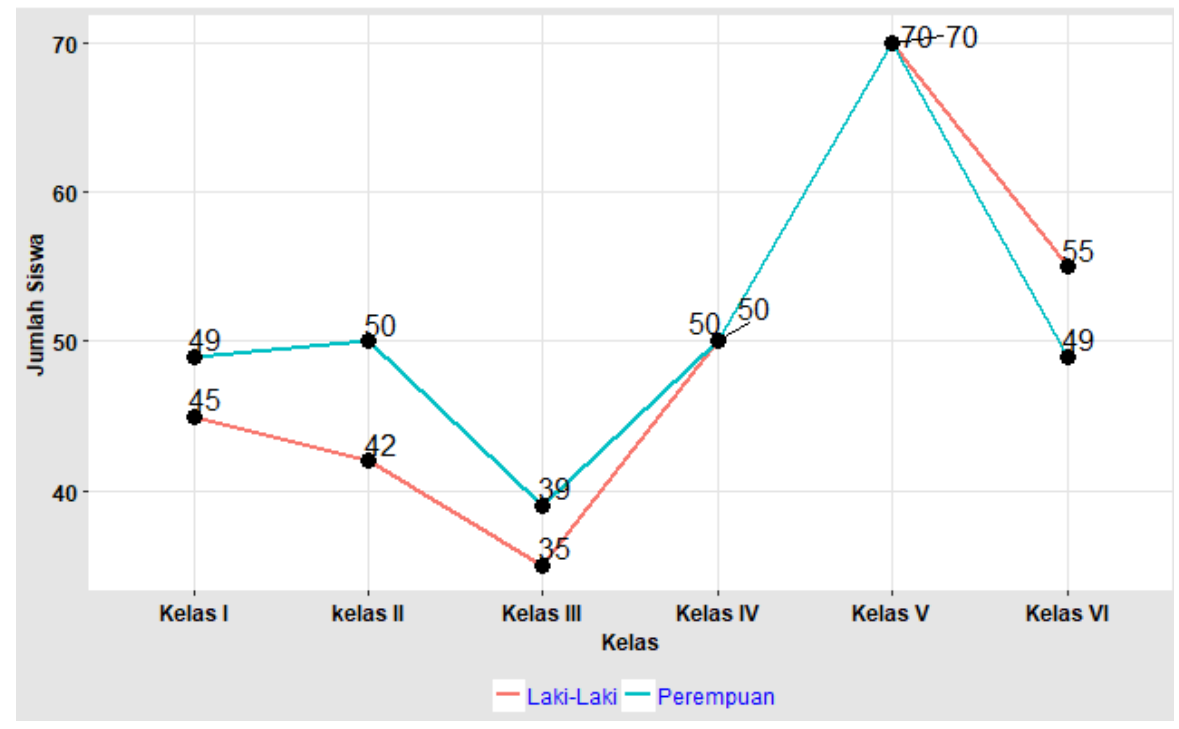

Gambar 1.1 Grafik Garis Frekuensi

Untuk membuat grafik garis frekuensi pada Gambar 1.1, kita akan menggunakan menu Line: Other-II (Gambar 1.2).

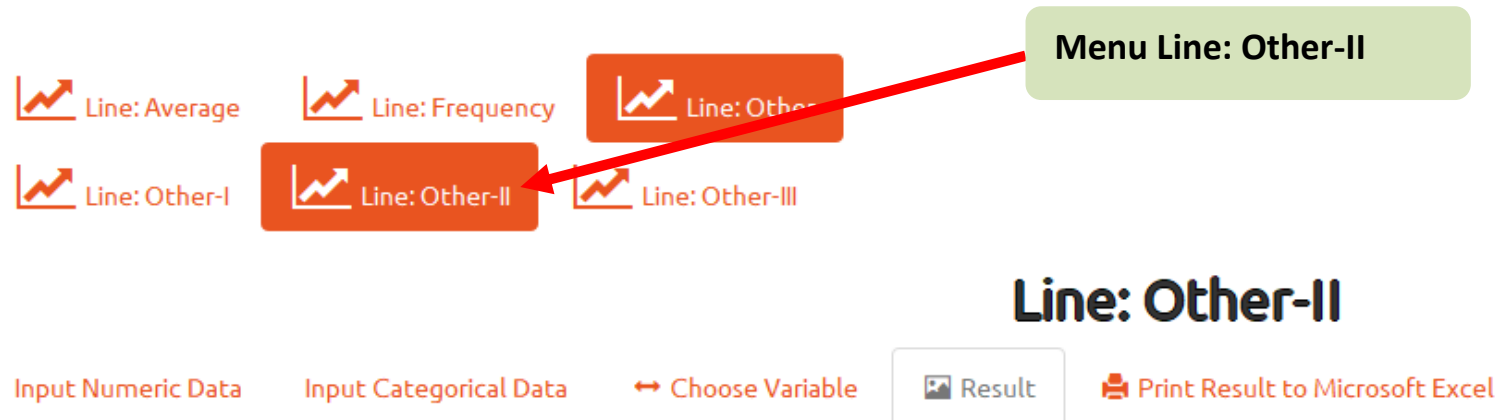

\section{Gambar 1.2 Menu Line: Other-II}

Untuk mengakses menu Line: Other-II, pilih Graph $=>$ Line $=>$ Line: Other $=>$ Line: Other-

II (Gambar 1.2). Dengan menggunakan data pada Tabel 1.1, input data seperti pada Gambar 1.3 (untuk data numerik) dan Gambar 1.4 (untuk data kategori). 


\section{Line: Other-II}

Input Numeric Data Input Categorical Data $\leftrightarrow$ Choose Variable $\quad$ Result $\quad \Leftrightarrow$ Print Result to Microsoft Excel $\quad$ watch Tutorial Video

\section{Input Numeric Data}

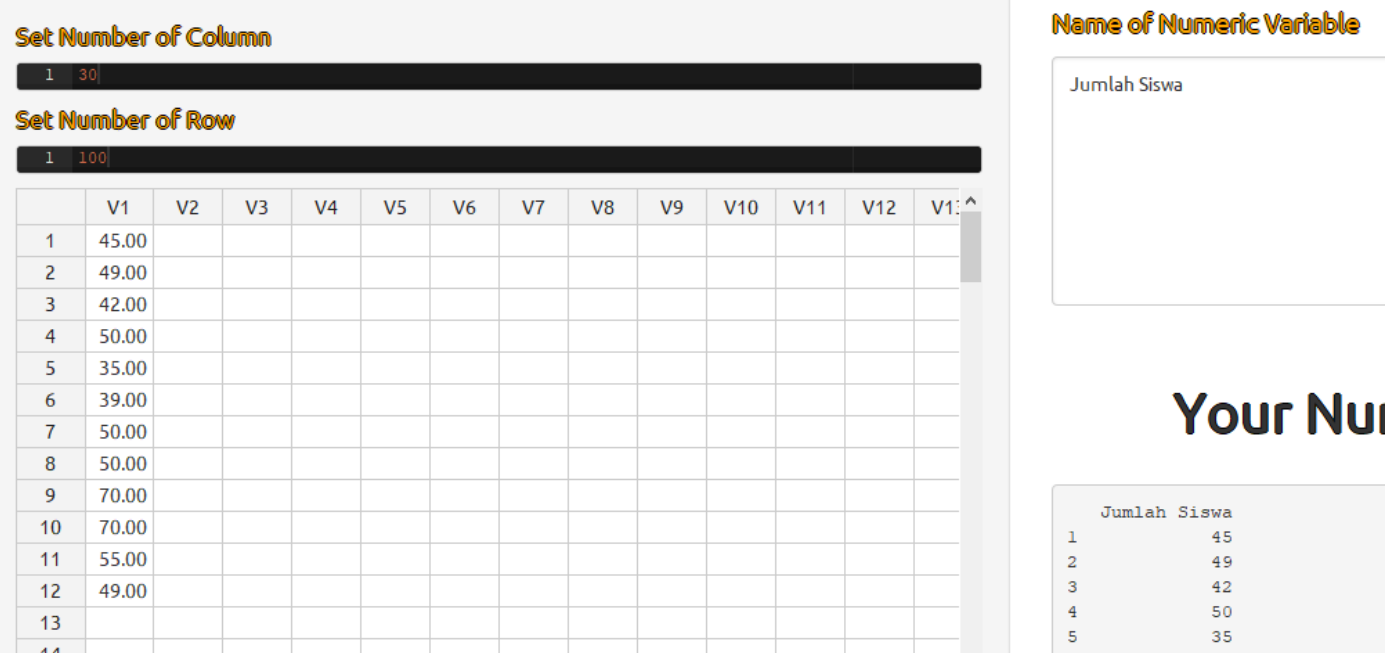

Gambar 1.3 Input Data Numerik pada Menu Line: Other-II

Line: Other-II

Input Numeric Data Input Categorical Data $\leftrightarrow$ Choose Variable Result 블 Print Result to Microsoft Excel

\section{Input Categorical Data}

\section{Set Nunomber of Coluono}
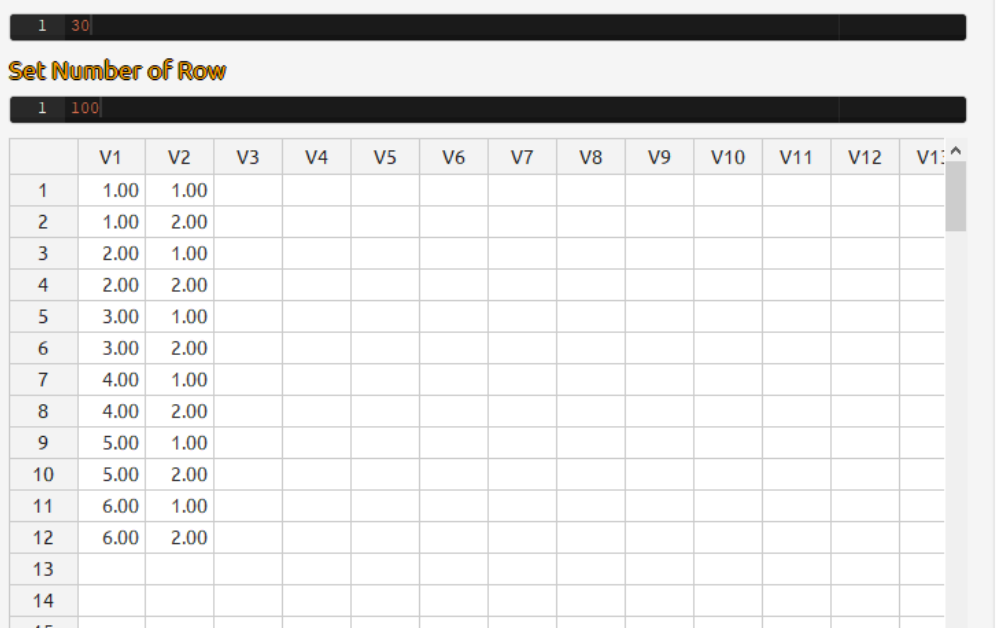

Nane of Categorical Variable

\section{Kelas}

Jenis Kelamin

Order

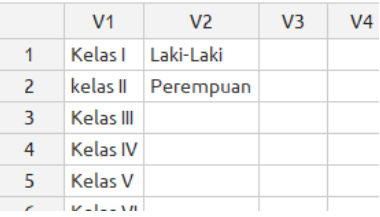

Gambar 1.4 Input Data Kategori pada Menu Line: Other-II 
Lakukan pemilihan variabel pada bagian Choose Variable, seperti pada Gambar 1.5.

$\begin{array}{lc} & \text { Line: Other-ll } \\ \text { Input Numeric Data Input Categorical Data } & \leftrightarrow \text { Choose Variable } \\ \text { m Watch Tutorial Video Result }\end{array}$

Choose Numieric Variable (Single Choice) (Frequency/Mean)

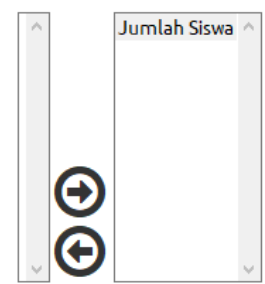

Choose Categorical Variable (Single Choice)

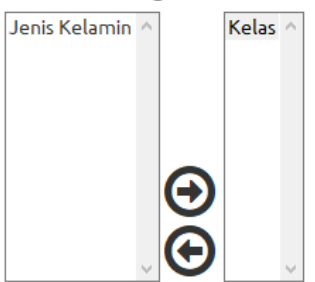

Choose Categorical Variable (Single Choice) (Category as Line/Grovp)

Kelas $\wedge$ Jenis Kelamin A

Choose Categorical Variable (Single Choice)

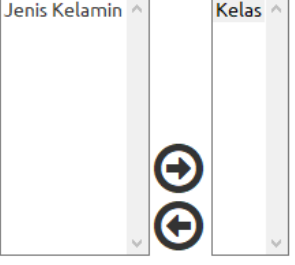

Choose Categorical Variable (Single Choice) (Category as Line/Group)

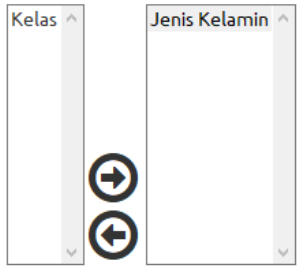

Choose Nunneric Variable (Single Choice) (Percentage/Standard Deviation)

Jumlah Siswa

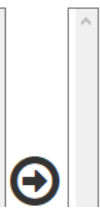

Gambar 1.5 Pemilihan Variabel 
Hasil dari grafik garis frekuensi dapat dilihat pada bagian Result $=>$ Print Result (Gambar 1.6).

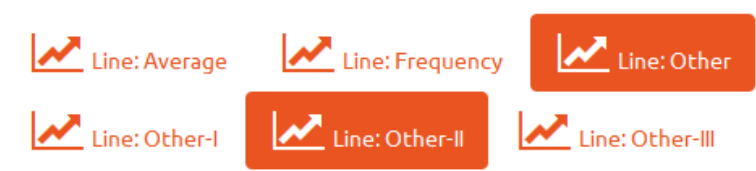

\section{Line: Other-II}

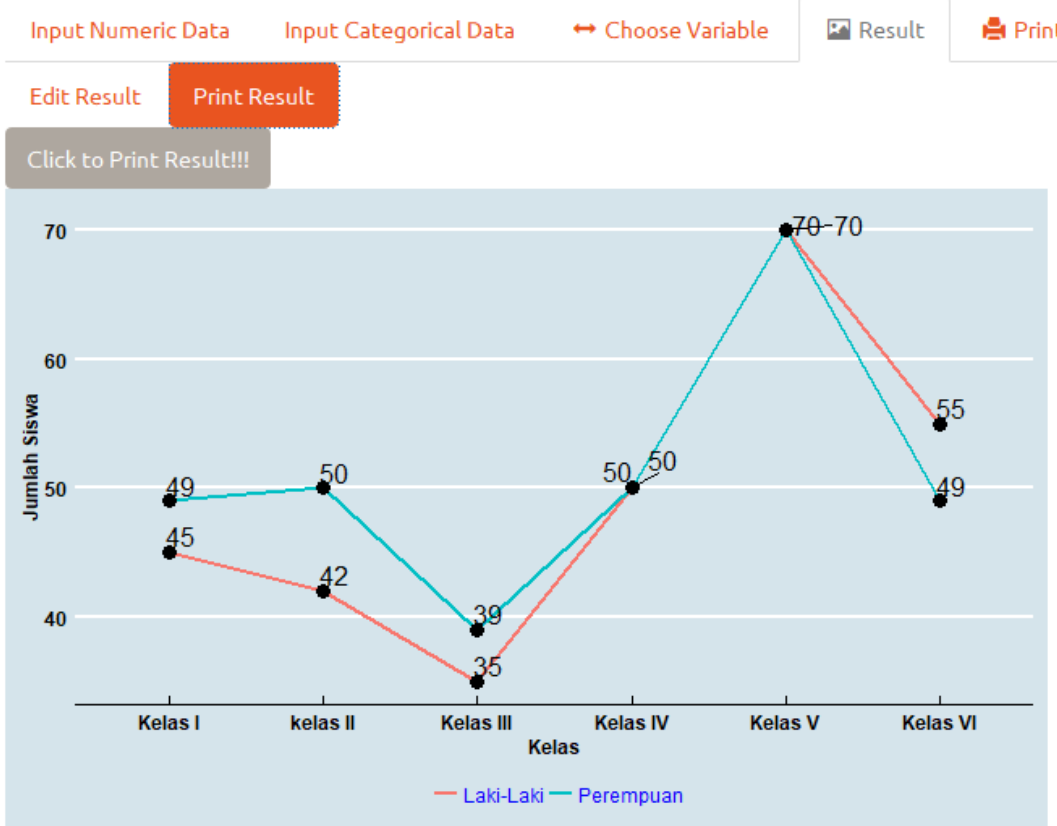

Gambar 1.6 Grafik Garis Frekuensi 


\section{Mengolah Data dengan}

Program Aplikasi Statistika

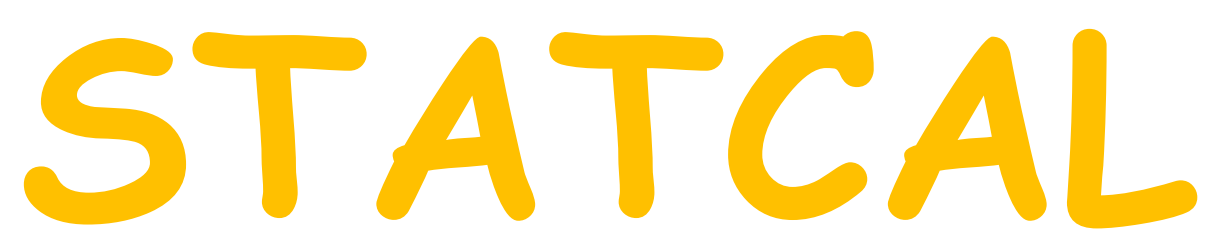

Membuat Grafik Garis Rata-Rata dengan Menu Line: Other-II

\section{Oleh Prana Ugiana Gio}

Founder \& CEO STATCAL

Created by Prana Ugiana Gio \& Rezzy Eko Caraka

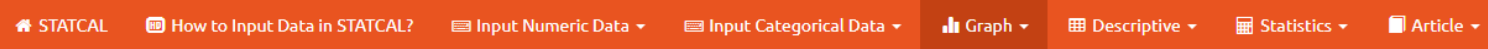

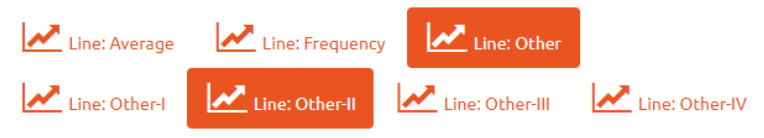

Line: Other-II
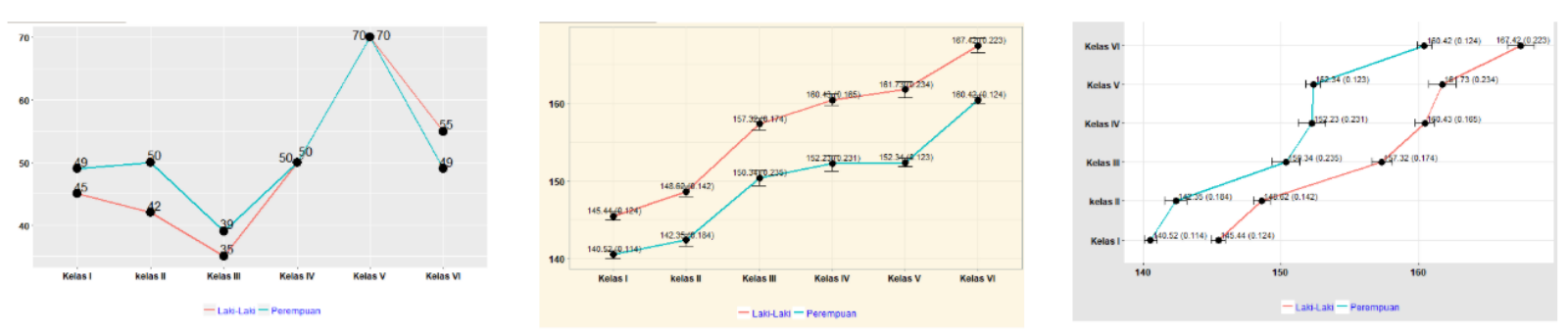
Misalkan diberikan data rata-rata tinggi badan dan standar deviasi berdasarkan kelas dan jenis kelamin (Tabel 1.1).

Tabel 1.1 Data Rata-Rata Tinggi Badan berdasarkan Kelas dan Jenis Kelamin (Data Fiktif)

\begin{tabular}{|c|c|c|c|}
\hline Kelas & Jenis Kelamin & Tinggi Badan & Standar Deviasi \\
\hline 1 & 1 & 145.44 & 0.124 \\
\hline 1 & 2 & 140.52 & 0.114 \\
\hline 2 & 1 & 148.62 & 0.142 \\
\hline 2 & 2 & 142.35 & 0.184 \\
\hline 3 & 1 & 157.32 & 0.174 \\
\hline 3 & 2 & 150.34 & 0.235 \\
\hline 4 & 1 & 160.43 & 0.165 \\
\hline 4 & 2 & 152.23 & 0.231 \\
\hline 5 & 1 & 161.73 & 0.234 \\
\hline 5 & 2 & 152.34 & 0.123 \\
\hline 6 & 1 & 167.42 & 0.223 \\
\hline 6 & 2 & 160.42 & 0.124 \\
\hline
\end{tabular}

\begin{tabular}{|c|c|c|}
\hline Angka & Kelas & Jenis Kelamin \\
\hline 1 & Kelas I & Laki-Laki \\
\hline 2 & kelas II & Perempuan \\
\hline 3 & Kelas III & \\
\hline 4 & Kelas IV & \\
\hline 5 & Kelas V & \\
\hline 6 & Kelas VI & \\
\hline
\end{tabular}

Berdasarkan data pada Tabel 1.1, diketahui rata-rata tinggi badan anak kelas I laki-laki adalah 145,44, dengan standar deviasi 0,124. Rata-rata tinggi badan anak kelas I perempuan adalah 140,52, dengan standar deviasi 0,114, dan seterusnya. Dari data pada Tabel 1.1, disajikan grafik garis rata-rata seperti pada Gambar 1.1. 


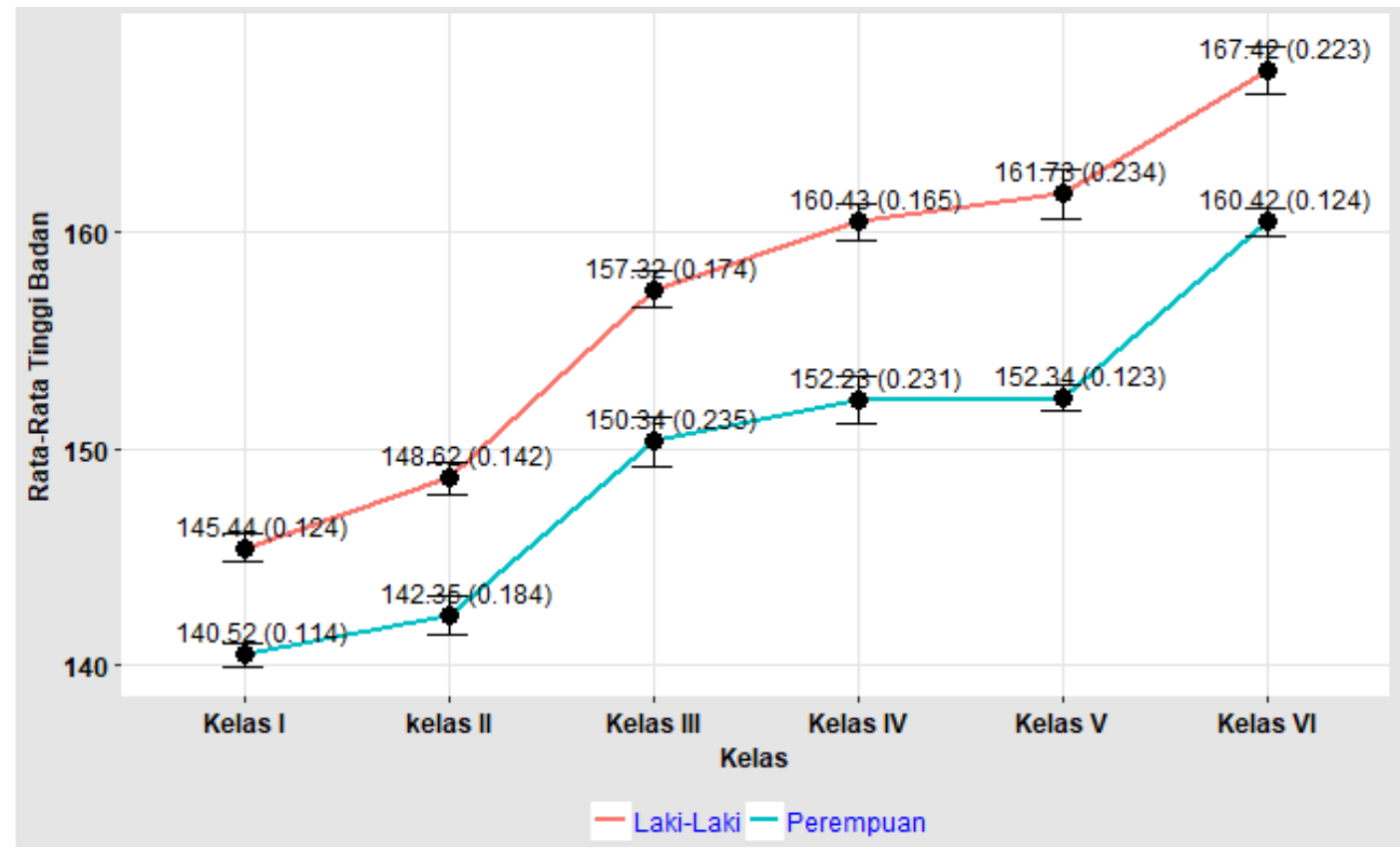

Gambar 1.1 Grafik Garis Rata-Rata

Untuk membuat grafik garis rata-rata pada Gambar 1.1, kita akan menggunakan menu Line: Other-II (Gambar 1.2).

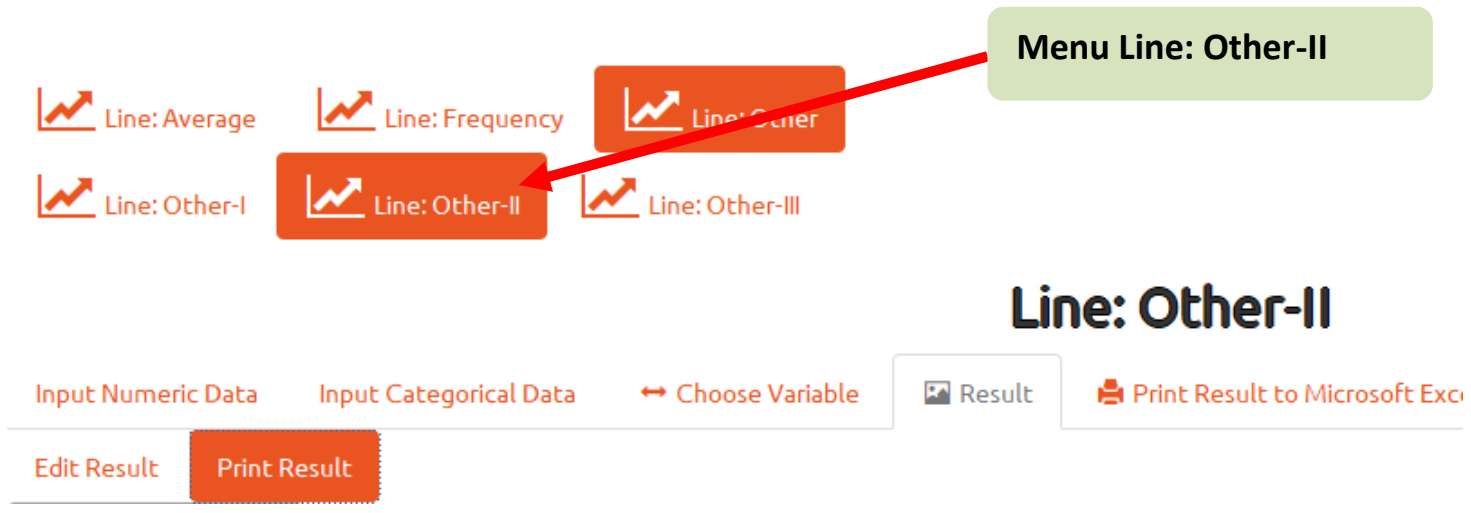

Gambar 1.2 Menu Line: Other-II

Untuk mengakses menu Line: Other-II, pilih Graph $=>$ Line $=>$ Line: Other $=>$ Line: OtherII (Gambar 1.2). Dengan menggunakan data pada Tabel 1.1, input data seperti pada Gambar 1.3 (data numerik) dan Gambar 1.4 (data kategori). 
Line: Other-II

Input Numeric Data

Input Categorical Data

$\rightarrow$ Choose Variable

Result

볼 Print Result to Microsoft Excel

Watch Tutorial Video

Related Article

Input Numeric Data

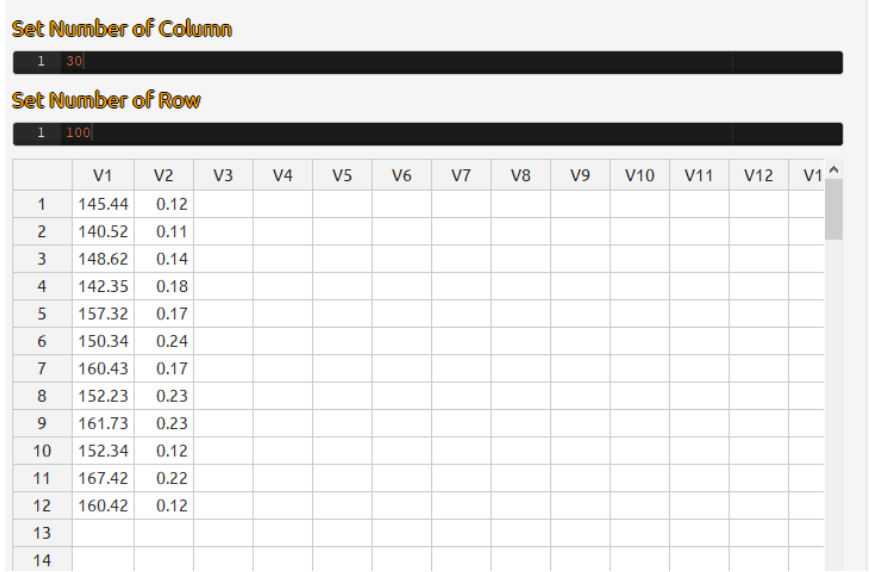

Nanne of Nunneric Variable

Rata-Rata Tinggi Badan

Standar Deviasi

Your Numeric Data

Gambar 1.3 Input Data Numerik pada Menu Line: Other-II

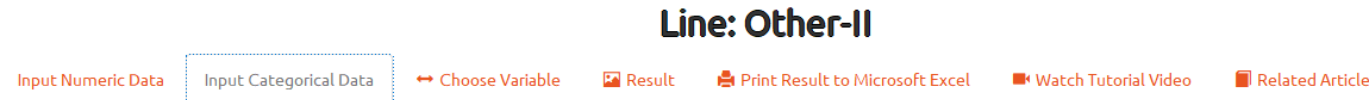

Input Categorical Data
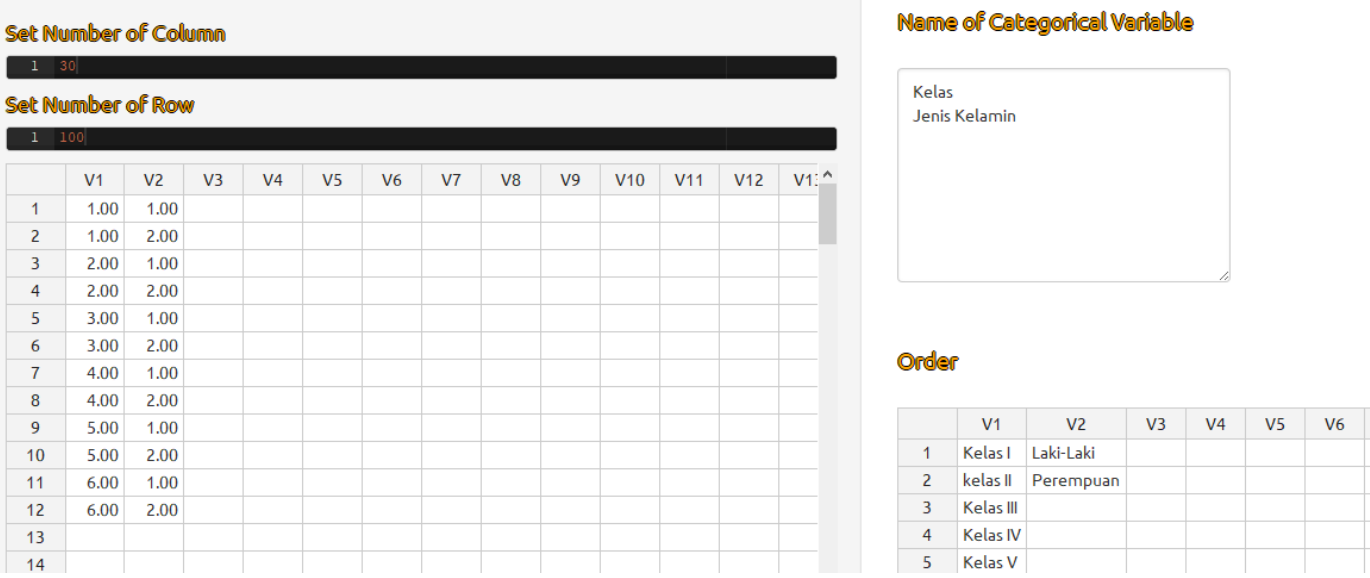

Gambar 1.4 Input Data Kategori pada Menu Line: Other-II

Pada bagian Choose Variable, Lakukan pemilihan variabel seperti pada Gambar 1.5. 


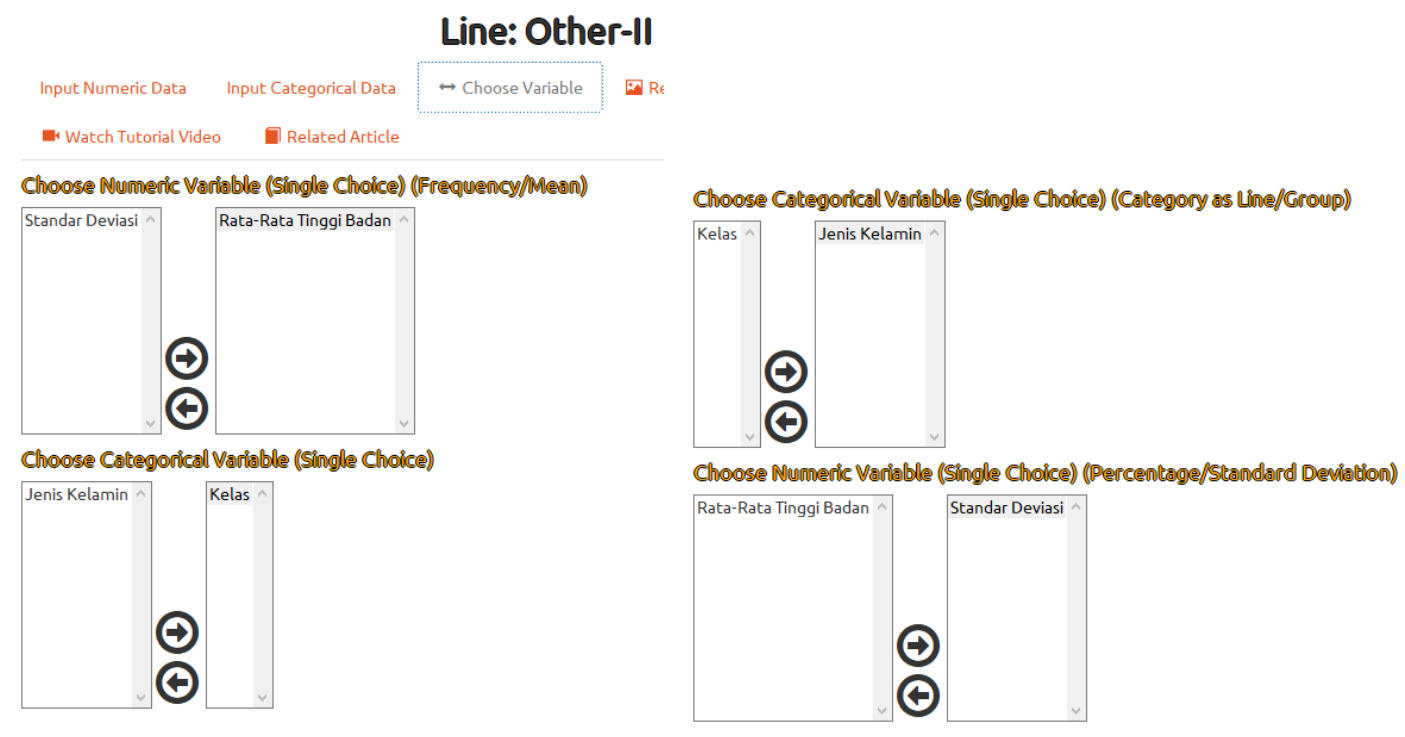

Gambar 1.5 Pemilihan Variabel

Hasil dari grafik garis rata-rata dapat dilihat pada bagian Result => Print Result (Gambar 1.6).

\section{Line: Other-II}

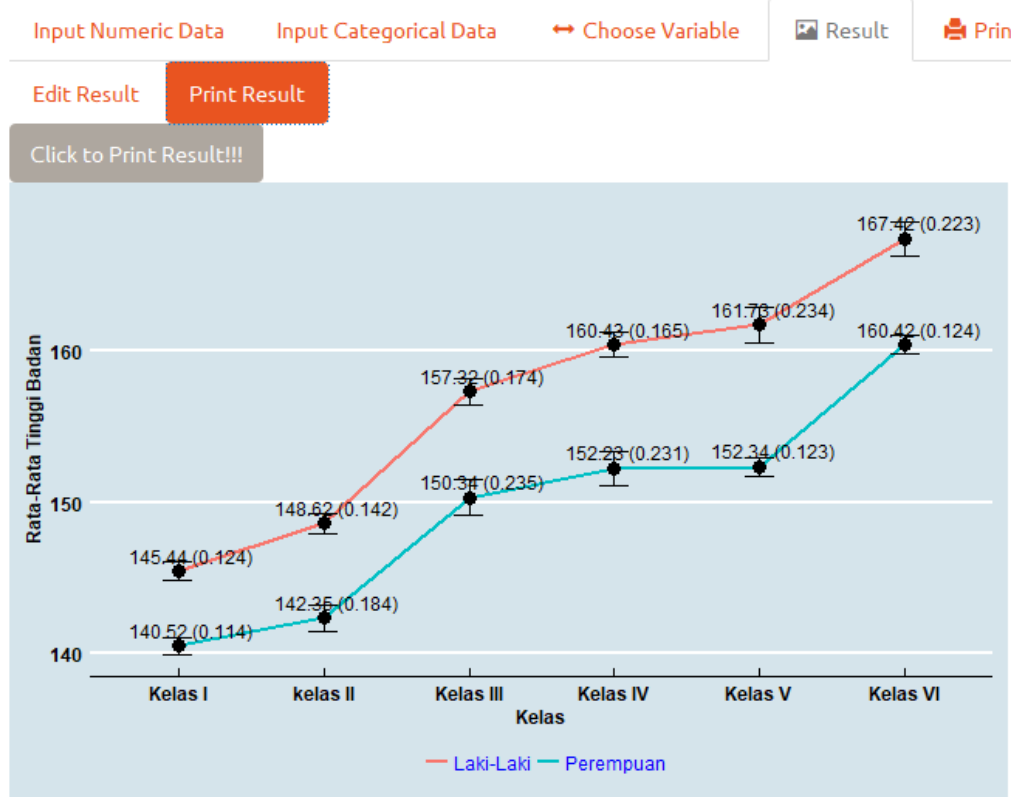

Gambar 1.6 Grafik Garis Rata-Rata 


\section{Mengolah Data dengan}

Program Aplikasi

\section{Statistika}

Membuat Grafik Garis dengan Menu

$$
\text { Line: Other-III }
$$

\section{Oleh Prana Ugiana Gio}

Founder \& CEO STATCAL

Created by Prana Ugiana Gio \& Rezzy Eko Caraka

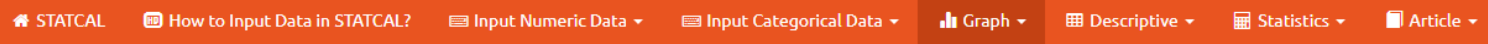

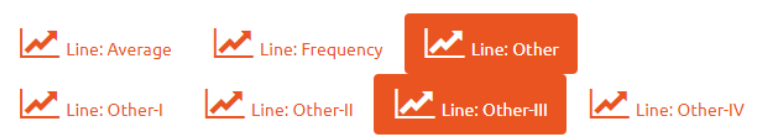

Line: Other-III

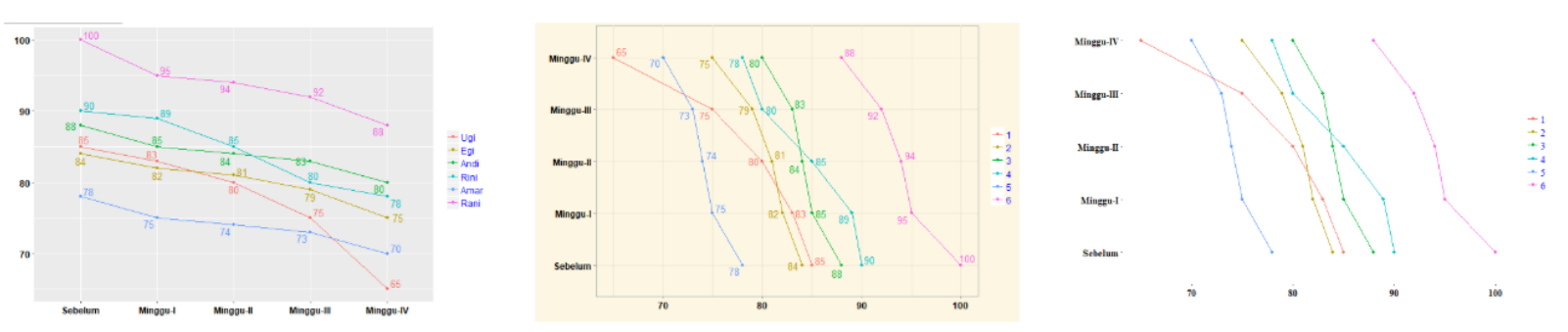


Misalkan diberikan data berat badan dari 6 responden, pada saat sebelum mengkonsumsi obat diet $\mathrm{ABCD}$, setelah mengkonsumsi obat diet ABCD minggu ke-I, minggu ke-II, minggu ke-III dan minggu ke-IV (Tabel 1.1).

\section{Tabel 1.1 Data Berat Badan (Data Fiktif)}

\begin{tabular}{|c|c|c|c|c|c|}
\hline \multirow{2}{*}{ Nama } & \multicolumn{5}{|c|}{ Berat Badan (Sebelum dan Sesudah) Mengkonsumsi Obat Diet ABC } \\
\cline { 2 - 6 } & Sebelum & Minggu Ke-I & Minggu Ke-II & Minggu Ke-III & Minggu Ke-IV \\
\hline 1 & 85 & 83 & 80 & 75 & 65 \\
\hline 2 & 84 & 82 & 81 & 79 & 75 \\
\hline 3 & 88 & 85 & 84 & 83 & 80 \\
\hline 4 & 90 & 89 & 85 & 80 & 78 \\
\hline 5 & 78 & 75 & 74 & 73 & 70 \\
\hline 6 & 100 & 95 & 94 & 92 & 88 \\
\hline
\end{tabular}

\begin{tabular}{|c|c|}
\hline Angka & Nama \\
\hline 1 & Ugi \\
\hline 2 & Egi \\
\hline 3 & Andi \\
\hline 4 & Rini \\
\hline 5 & Amar \\
\hline 6 & Rani \\
\hline
\end{tabular}

Berdasarkan data pada Tabel 1.1, diketahui responden yang bernama Ugi, memiliki berat badan awal (sebelum) $85 \mathrm{~kg}$. Kemudian setelah mengkonsumsi obat diet ABC selama 1 minggu, berat badannya turun menjadi $83 \mathrm{~kg}$, pada minggu ke-2, turun lagi menjadi 80, sampai pada minggu ke-4, turun menjadi $65 \mathrm{~kg}$, dan seterusnya. Dari data pada Tabel 1.1, disajikan grafik garis seperti pada Gambar 1.1. Pada Gambar 1.1, terlihat bahwa, dari 6 responden tersebut, terjadi penurunan berat badan, dari minggu ke-I, sampai minggu ke-IV. 


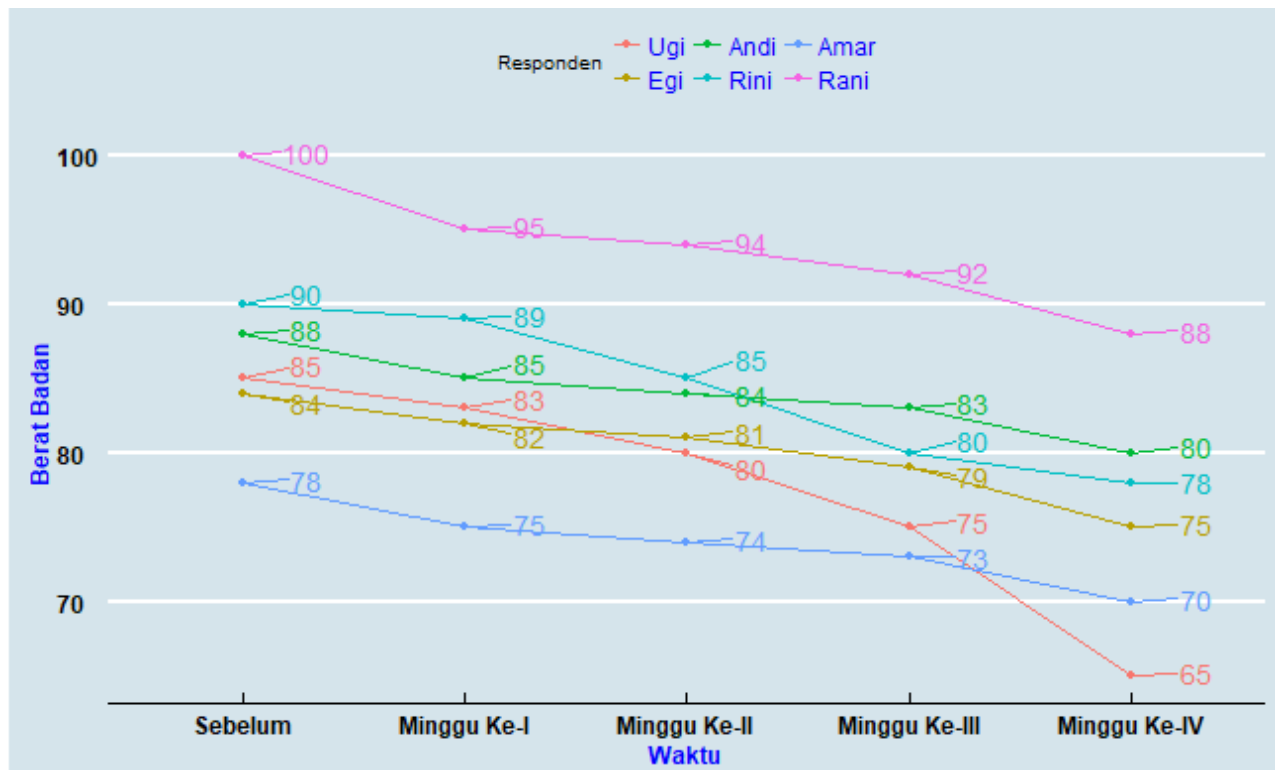

Gambar 1.1 Grafik Garis

Untuk membuat grafik garis seperti pada Gambar 1.1, kita akan menggunakan menu Line:

Other-III (Gambar 1.2).

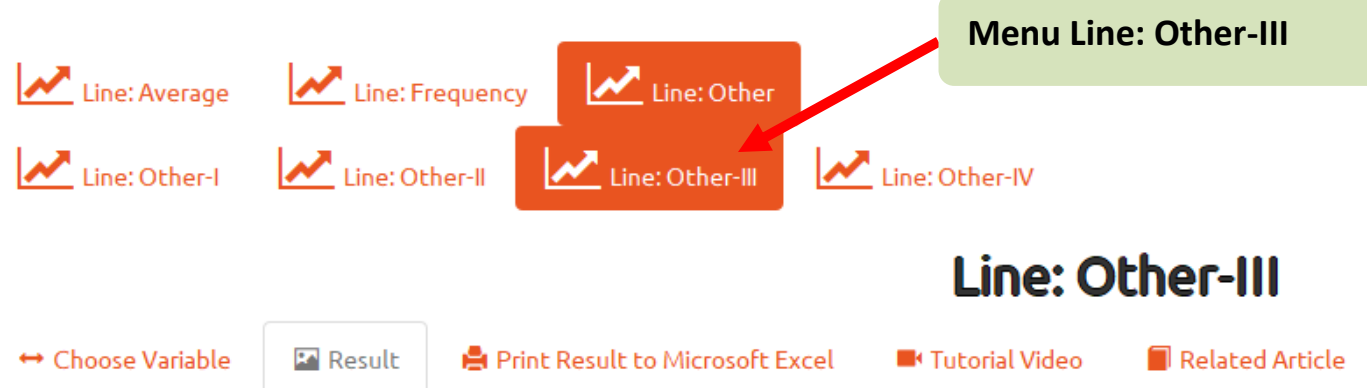

Gambar 1.2 Menu Line: Other-III

Tahap pertama, input data terlebih dahulu (Gambar 1.3 dan Gambar 1.4). 


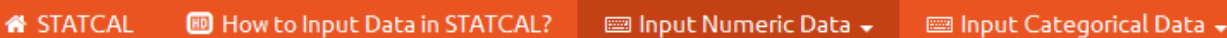

\section{国 Input Numeric Data}

Numeric Data

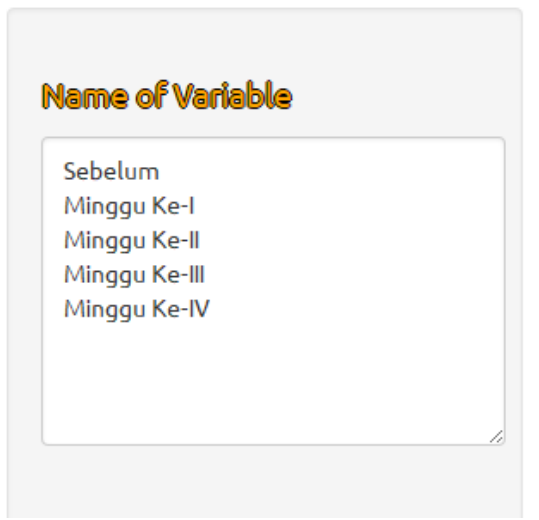

Sett Nuñber of Colmôn

\begin{tabular}{|c|c|c|c|c|c|c|c|c|}
\hline \multicolumn{9}{|c|}{ Sett Nunber of Row } \\
\hline \multicolumn{9}{|c|}{$1 \quad 100$} \\
\hline & V1 & V2 & V3 & V4 & V5 & V6 & V7 & v8 \\
\hline 1 & 85.00 & 83.00 & 80.00 & 75.00 & 65.00 & & & \\
\hline 2 & 84.00 & 82.00 & 81.00 & 79.00 & 75.00 & & & \\
\hline 3 & 88.00 & 85.00 & 84.00 & 83.00 & 80.00 & & & \\
\hline 4 & 90.00 & 89.00 & 85.00 & 80.00 & 78.00 & & & \\
\hline 5 & 78.00 & 75.00 & 74.00 & 73.00 & 70.00 & & & \\
\hline 6 & 100.00 & 95.00 & 94.00 & 92.00 & 88.00 & & & \\
\hline
\end{tabular}

Gambar 1.3 Input Data Numerik

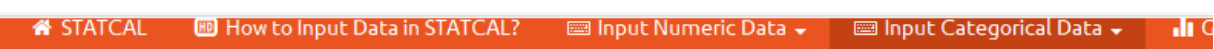

四 Input Categorical Data

\section{Categorical Data}

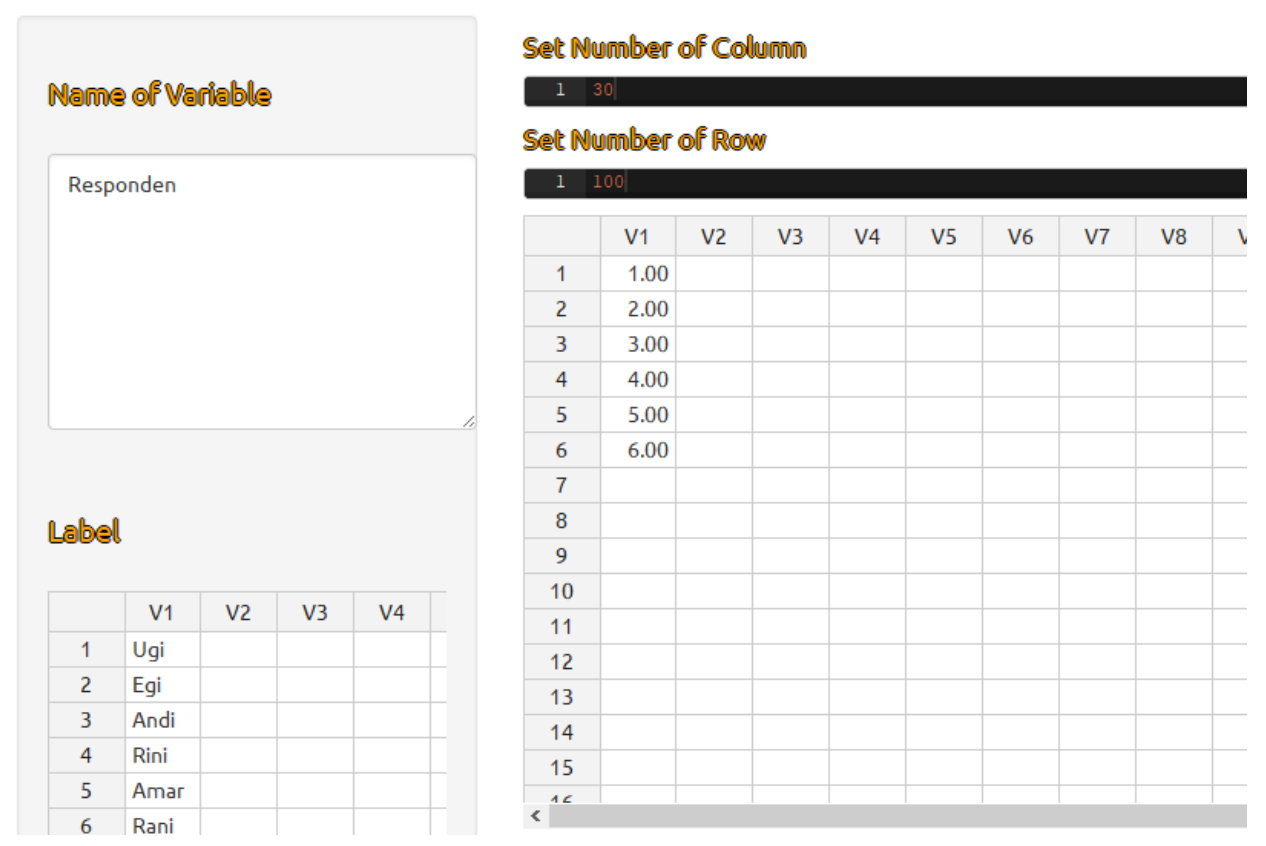

Gambar 1.4 Input Data Kategori 
Untuk mengakses menu Line: Other-III, pilih Graph $\Rightarrow$ Line $=>$ Line: Other $=>$ Line: Other-III (Gambar 1.2). Lakukan pemilihan variabel pada bagian Choose Variable, seperti pada Gambar 1.5.

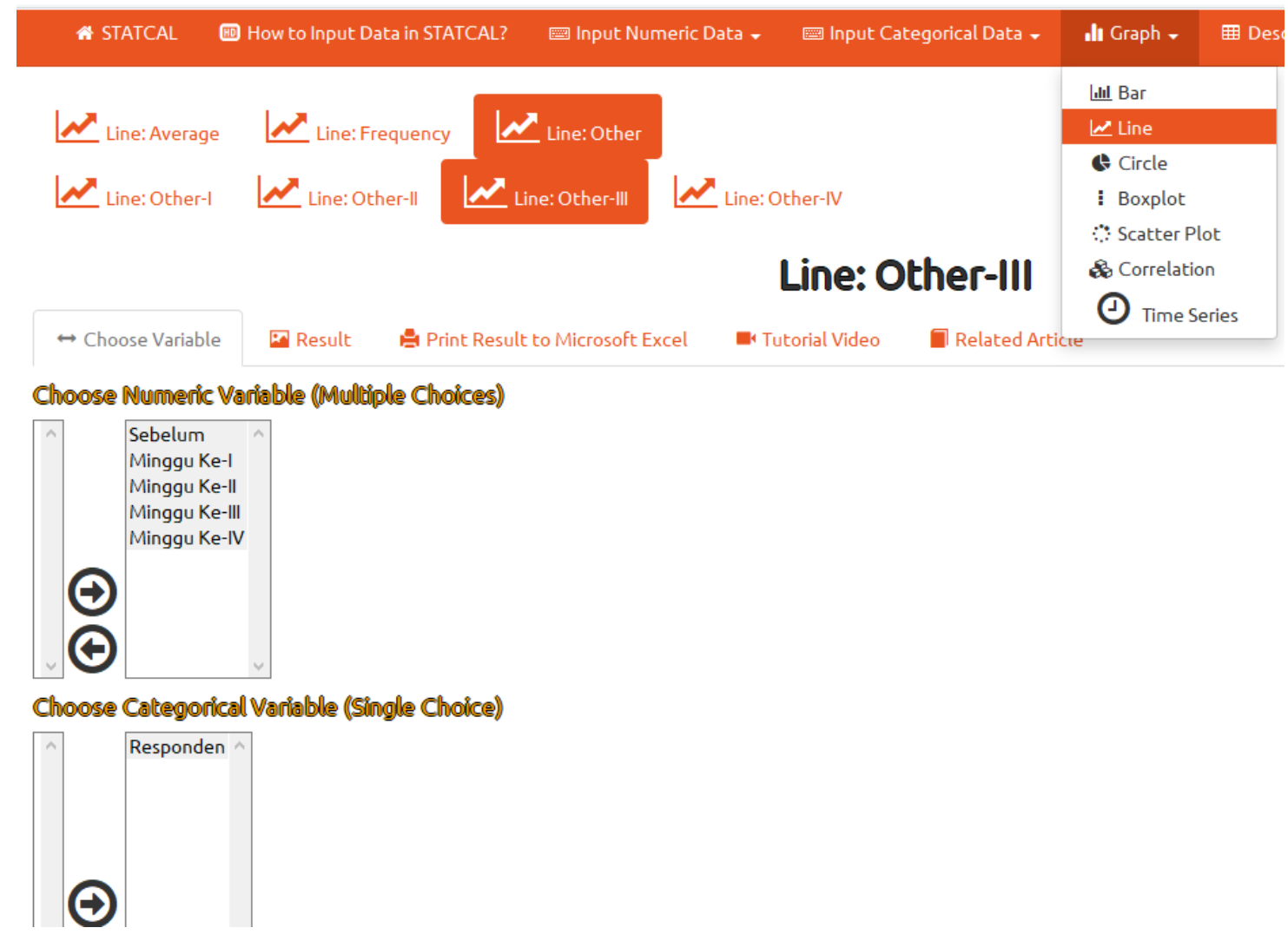

Gambar 1.5 Pemilihan Variabel

Hasil dari grafik garis dapat dilihat pada bagian Result => Print Result (Gambar 1.6). 


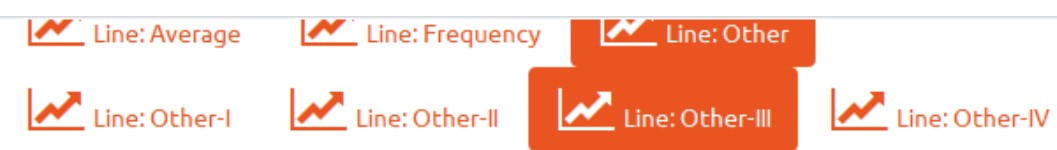

\section{Line: Other-III}

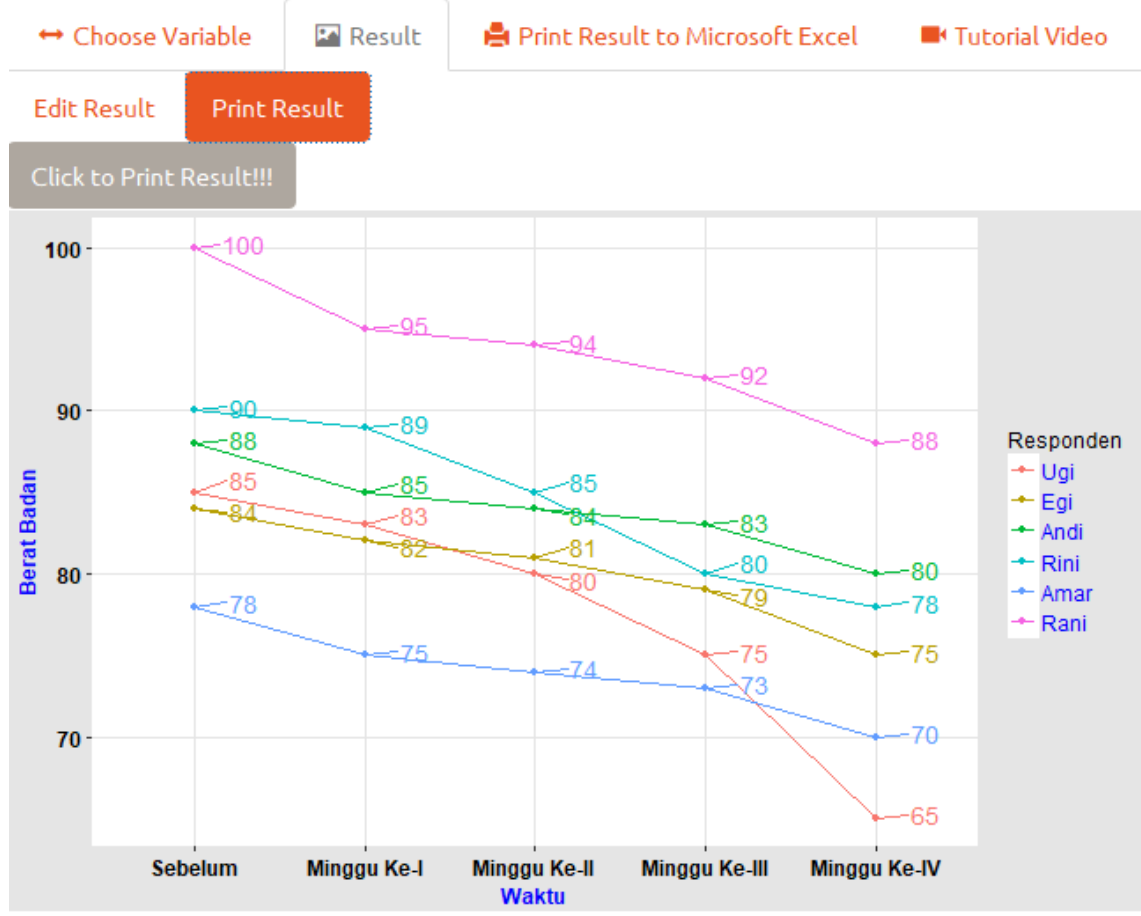

Gambar 1.6 Grafik Garis 


\section{Mengolah Data dengan} Program Aplikasi Statistika

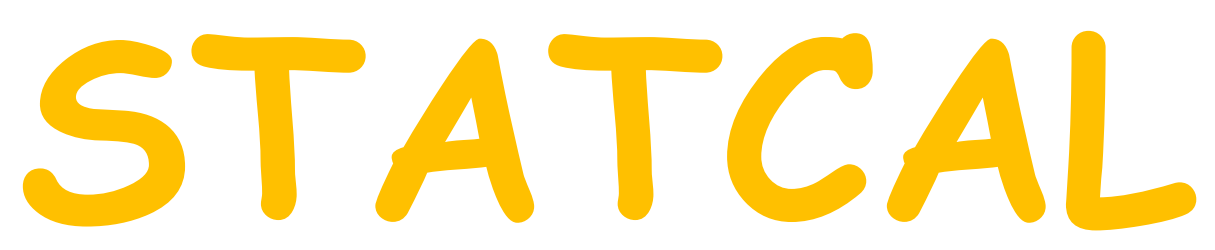

Membuat Grafik Lingkaran Frekuensi dengan Menu

$$
\text { Circle: Frequency-I }
$$

Oleh Prana Ugiana Gio

Founder \& CEO STATCAL

Created by Prana Ugiana Gio \& Rezzy Eko Caraka

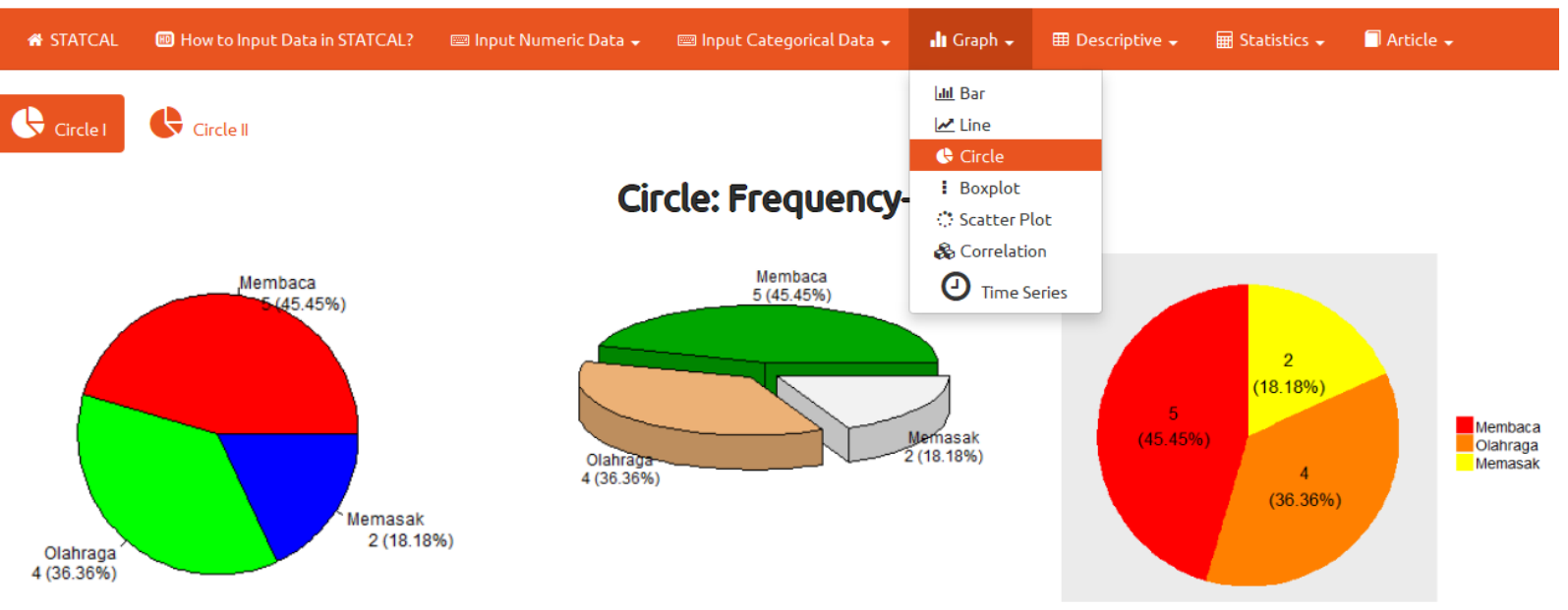


Misalkan diberikan data hobi dari 11 responden (Tabel 1.1).

Tabel 1.1 Data Hobi dari 11 Responden (Data Fiktif)

\begin{tabular}{|c|c|}
\hline Nama & Hobi \\
\hline Ugi & 1 \\
\hline Egi & 2 \\
\hline Andi & 3 \\
\hline Edi & 1 \\
\hline Rina & 1 \\
\hline Rini & 2 \\
\hline Suci & 2 \\
\hline Ani & 1 \\
\hline Fitri & 1 \\
\hline Tini & 2 \\
\hline Andi & 3 \\
\hline
\end{tabular}

\begin{tabular}{|c|c|}
\hline Angka & Hobi \\
\hline 1 & Membaca \\
\hline 2 & Olahraga \\
\hline 3 & Memasak \\
\hline
\end{tabular}

Berdasarkan data pada Tabel 1.1, diketahui responden yang bernama Ugi memiliki hobi membaca, responden yang bernama Egi memiliki hobi olahraga, dan seterusnya. Dari data pada Tabel 1.1, disajikan grafik lingkaran frekuensi seperti pada Gambar 1.1.
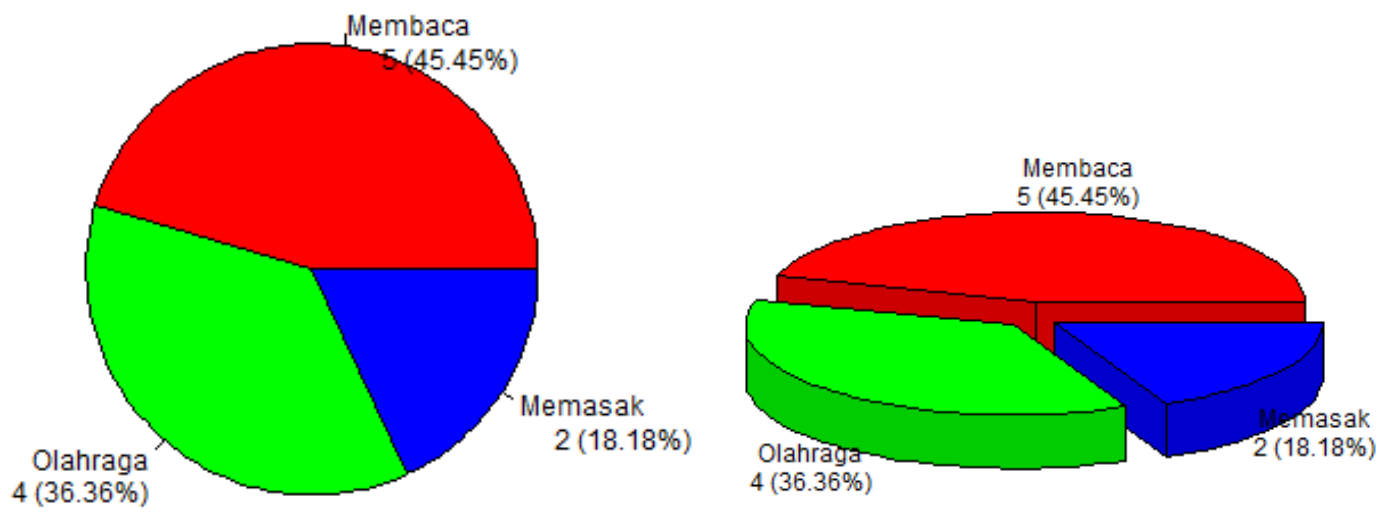

Gambar 1.1 Grafik Lingkaran Frekuensi 
Berdasarkan grafik lingkaran frekuensi pada Gambar 1.1, diketahui:

$\Rightarrow$ Jumlah responden dengan hobi membaca sebanyak $5(45,45 \%)$ responden.

$\Rightarrow$ Jumlah responden dengan hobi olahraga sebanyak $4(36,36 \%)$ responden.

$\Rightarrow$ Jumlah responden dengan hobi memasak sebanyak $2(18,18 \%)$ responden.

Untuk membuat grafik lingkaran frekuensi seperti pada Gambar 1.1, input data pada Tabel 1.1 ke dalam STATCAL, seperti pada Gambar 1.2.

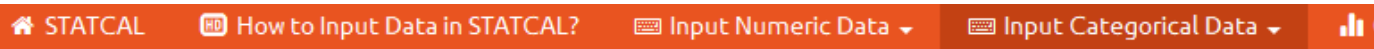

國 Input Categorical Data

\section{Categorical Data}

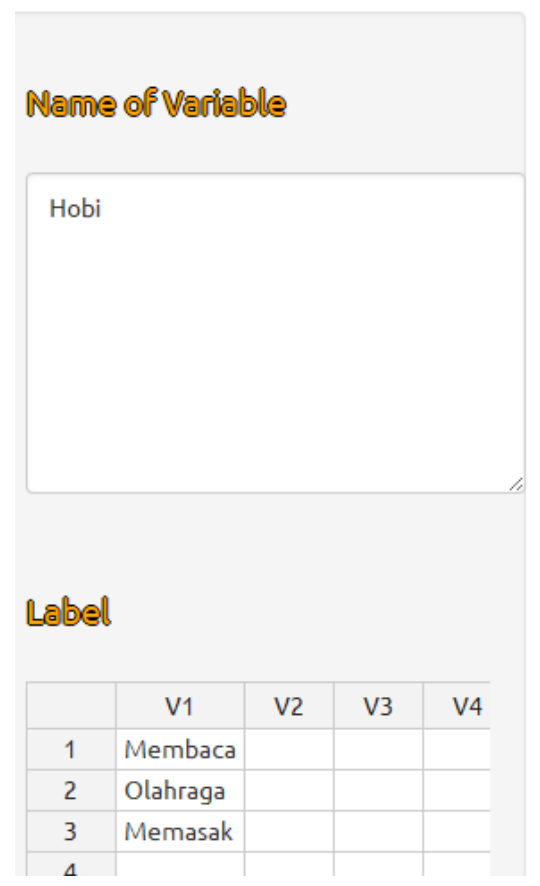

\section{Set Nunober of Colwñon}

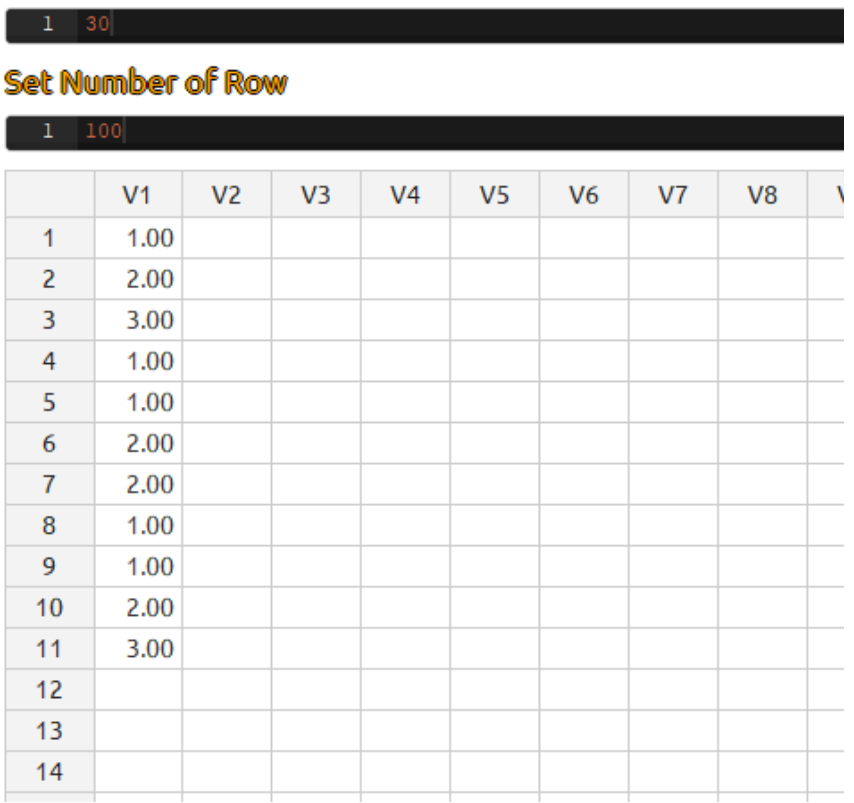

Gambar 1.2 Input Data Kategori

Selanjutnya pilih Graph $=>$ Circle $($ Gambar 1.3). 


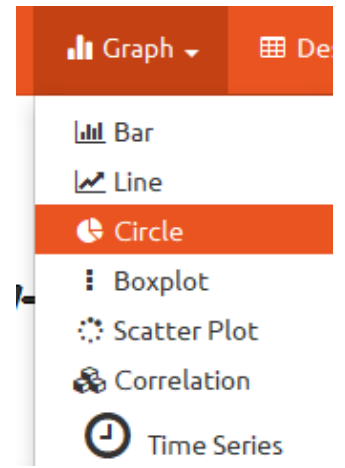

\section{Gambar 1.3 Menu Circle}

Pilih Circle: Frequency-I (Gambar 1.4).

Created by Prana Ugiana Gio \& Rezzy Eko Caraka

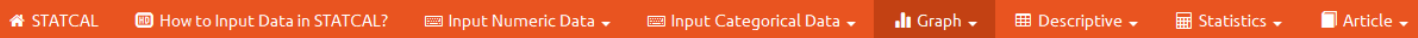

$\theta$ Girclel $\&$ circlell

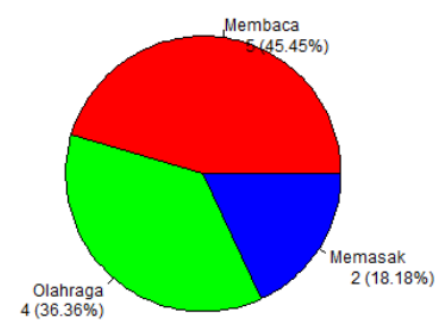

Circle: Frequency-I
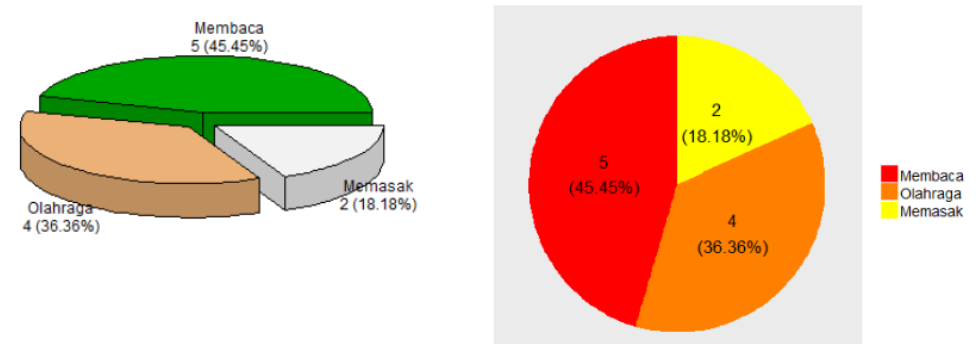

Gambar 1.4 Menu Circle: Frequency-I

Lakukan pemilihan variabel pada bagian Choose Variable, seperti pada Gambar 1.5. 


$$
\leftrightarrow \text { Choose Variable } \quad \text { Result Print Result to Mi }
$$

\section{Choose Categorical Variable (Single Choice)}

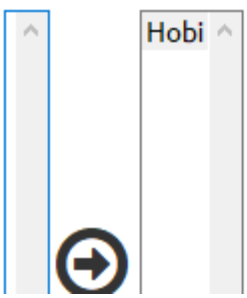

\section{Gambar 1.5 Pemilihan Variabel}

Hasil dari grafik lingkaran frekuensi dapat dilihat pada bagian Result (Gambar 1.6).

\begin{tabular}{l}
$\leftrightarrow$ Choose Variable \\
Edit Result Print Result \\
\hline Click to Print Result!!!
\end{tabular}

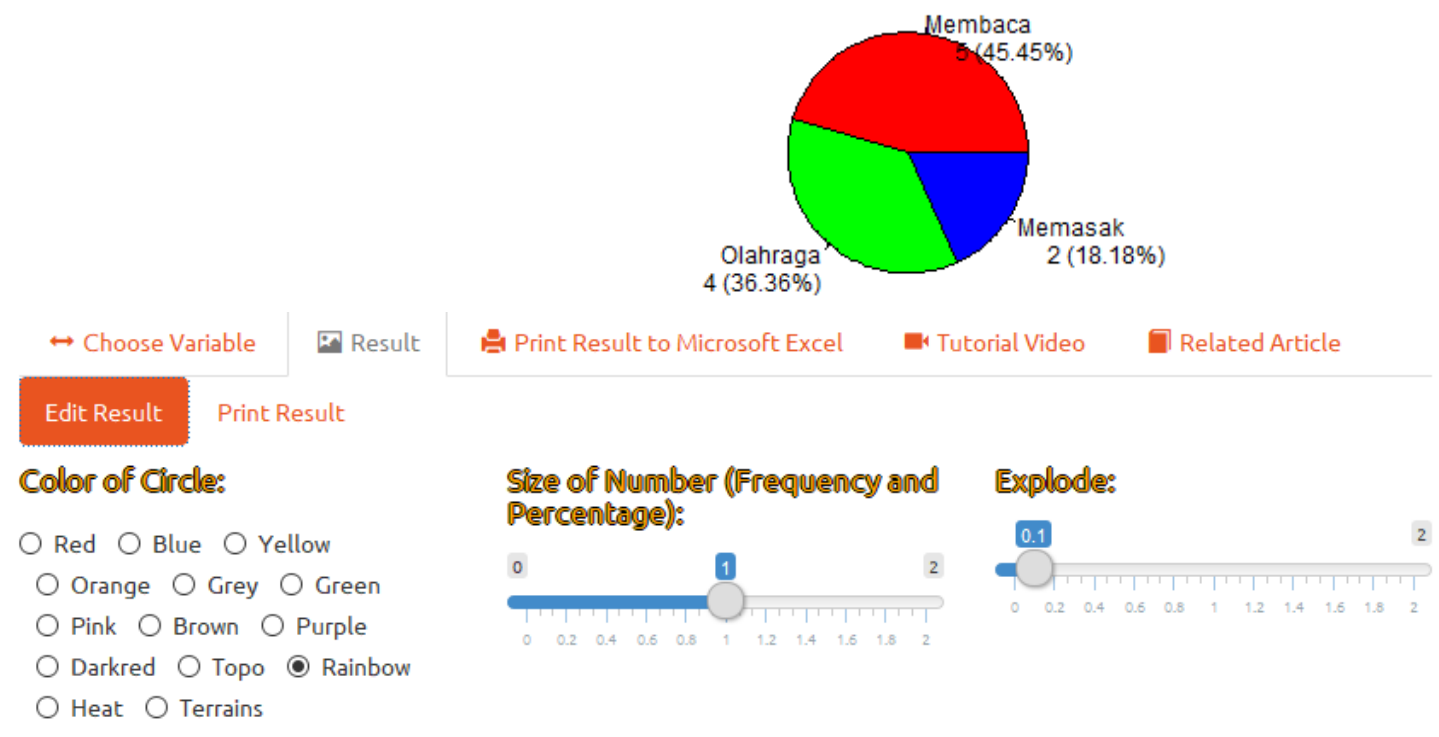

Gambar 1.6 Result 


\section{Mengolah Data dengan}

Program Aplikasi Statistika
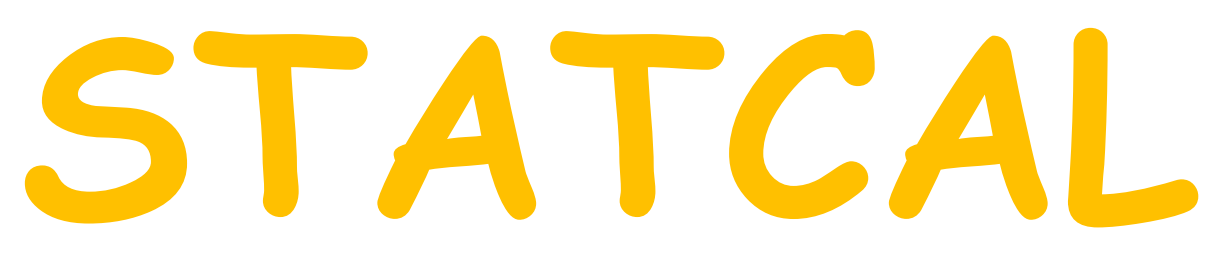

Membuat Grafik Lingkaran Frekuensi dengan Menu

Circle: Frequency-II

Oleh Prana Ugiana Gio

Founder \& CEO STATCAL

Created by Prana Ugiana Gio \& Rezzy Eko Caraka

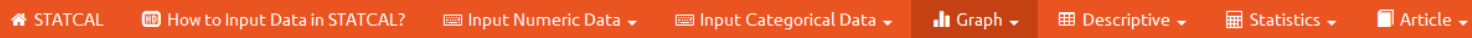

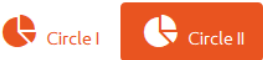

Circle: Frequency-II
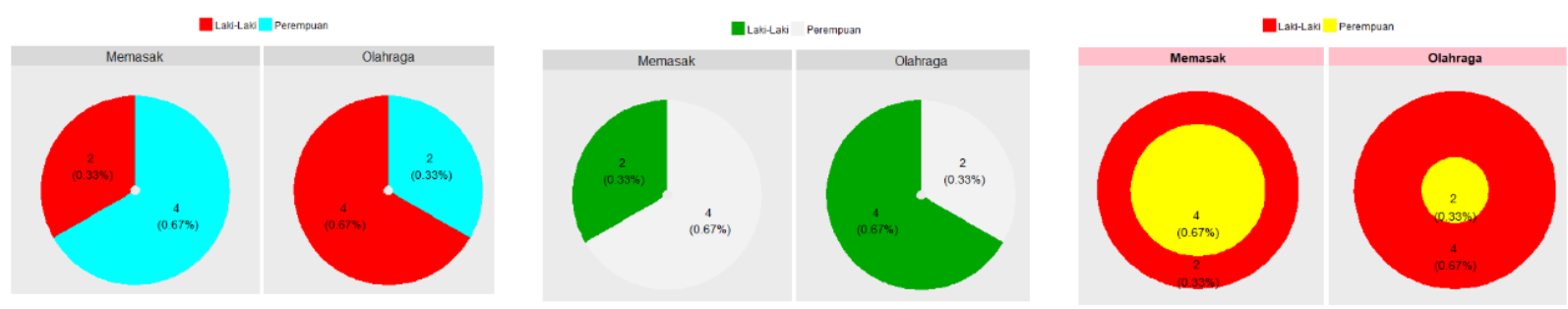
Misalkan diberikan data hobi dari 11 responden (Tabel 1.1).

Tabel 1.1 Data Hobi dari 11 Responden (Data Fiktif)

\begin{tabular}{|c|c|c|}
\hline Nama & Hobi & Jenis Kelamin \\
\hline Ugi & 1 & 1 \\
\hline Egi & 2 & 1 \\
\hline Andi & 3 & 1 \\
\hline Edi & 1 & 1 \\
\hline Rina & 1 & 1 \\
\hline Rini & 2 & 1 \\
\hline Suci & 2 & 1 \\
\hline Ani & 1 & 2 \\
\hline Fitri & 1 & 2 \\
\hline Tini & 2 & 2 \\
\hline Andi & 3 & 2 \\
\hline
\end{tabular}

\begin{tabular}{|c|c|c|}
\hline Angka & Hobi & Jenis Kelamin \\
\hline 1 & Membaca & Laki-Laki \\
\hline 2 & Olahraga & Perempuan \\
\hline 3 & Memasak & \\
\hline
\end{tabular}

Dari data pada Tabel 1.1, disajikan grafik lingkaran frekuensi seperti pada Gambar 1.2.

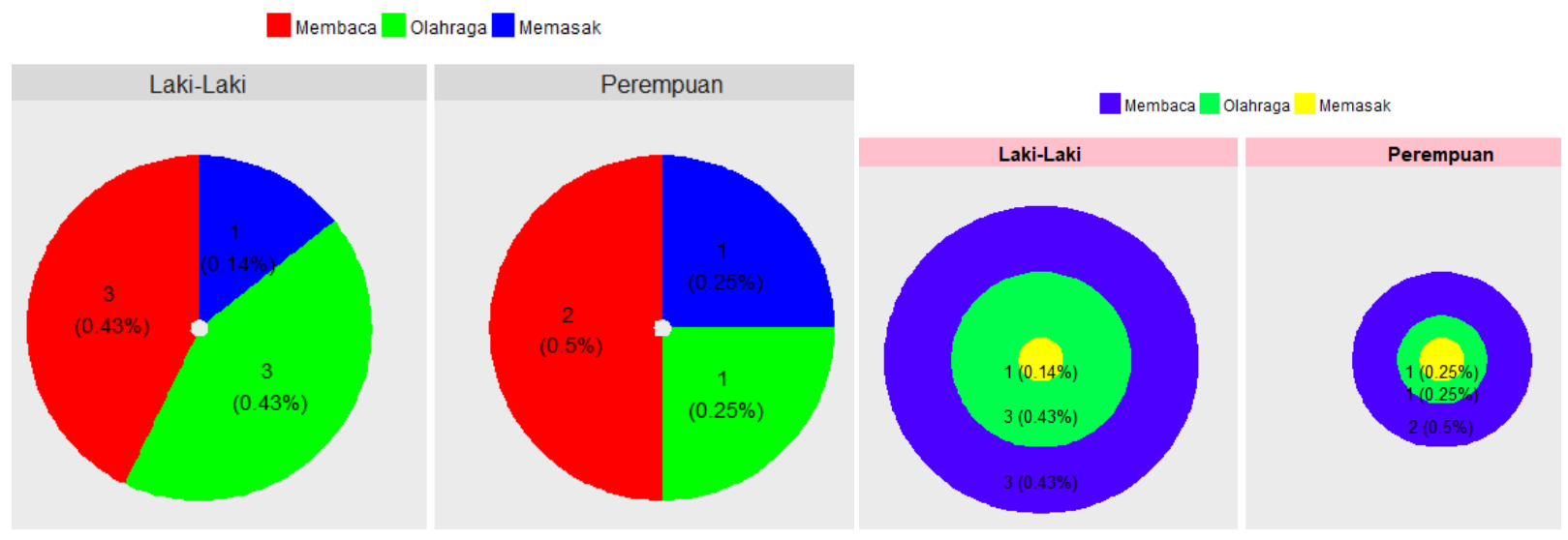

Gambar 1.1 Grafik Lingkaran Frekuensi 
Berdasarkan grafik lingkaran frekuensi pada Gambar 1.1, diketahui laki-laki yang hobi membaca sebanyak 3 orang, perempuan yang hobi membaca sebanyak 2 orang, dan seterusnya. Untuk membuat grafik lingkaran frekuensi seperti pada Gambar 1.1, input data pada Tabel 1.1 ke dalam STATCAL, seperti pada Gambar 1.2.

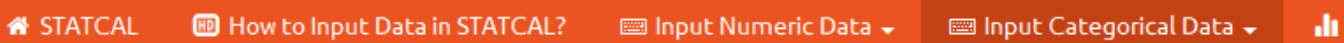

\section{国 Input Categorical Data}

\section{Categorical Data}

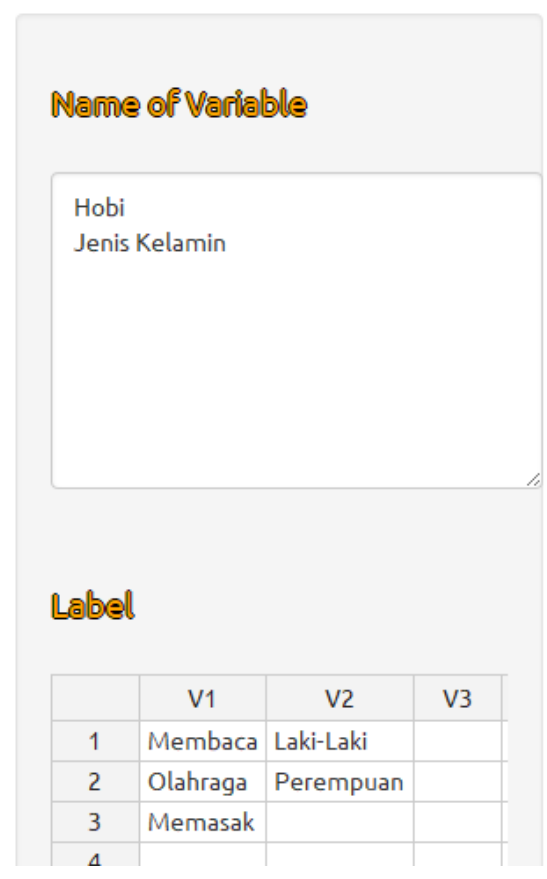

\begin{tabular}{|c|c|c|c|c|c|c|c|c|c|}
\hline \multicolumn{10}{|c|}{$\begin{array}{l}1 \\
10 \\
\text { et Nuñ ber of Row }\end{array}$} \\
\hline \multicolumn{10}{|c|}{$\begin{array}{ll}1 & 100 \\
\end{array}$} \\
\hline & $\mathrm{V} 1$ & V2 & V3 & V4 & V5 & V6 & v7 & v8 & 1 \\
\hline 1 & 1.00 & 1.00 & & & & & & & \\
\hline 2 & 2.00 & 1.00 & & & & & & & \\
\hline 3 & 3.00 & 1.00 & & & & & & & \\
\hline 4 & 1.00 & 1.00 & & & & & & & \\
\hline 5 & 1.00 & 1.00 & & & & & & & \\
\hline 6 & 2.00 & 1.00 & & & & & & & \\
\hline 7 & 2.00 & 1.00 & & & & & & & \\
\hline 8 & 1.00 & 2.00 & & & & & & & \\
\hline 9 & 1.00 & 2.00 & & & & & & & \\
\hline 10 & 2.00 & 2.00 & & & & & & & \\
\hline 11 & 3.00 & 2.00 & & & & & & & \\
\hline \multicolumn{10}{|l|}{12} \\
\hline \multicolumn{10}{|l|}{13} \\
\hline 14 & & & & & & & & & \\
\hline
\end{tabular}

Gambar 1.2 Input Data Kategori

Selanjutnya pilih Graph => Circle (Gambar 1.3). 


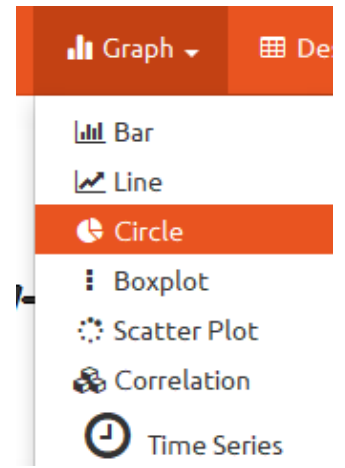

\section{Gambar 1.3 Menu Circle}

Pilih Circle: Frequency-II (Gambar 1.4).

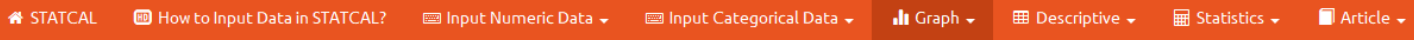

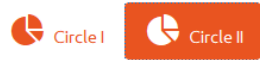

Circle: Frequency-II
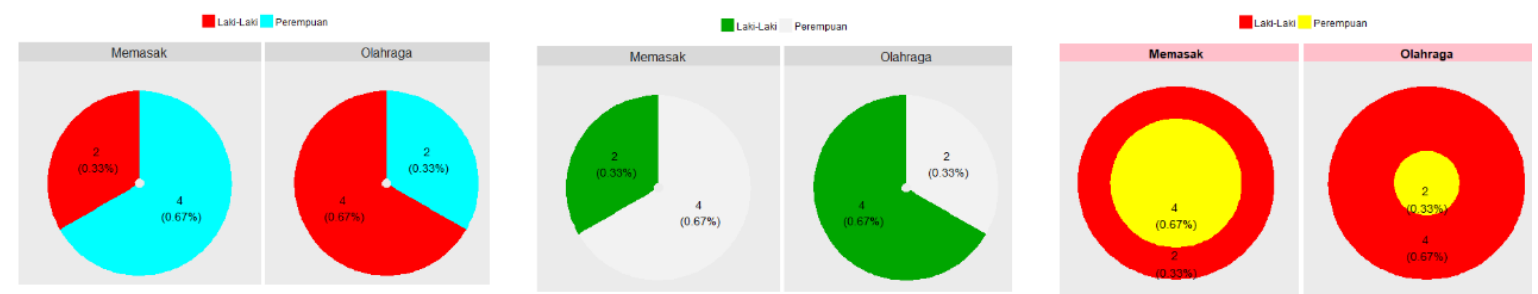

Gambar 1.4 Menu Circle: Frequency-II

Lakukan pemilihan variabel pada bagian Choose Variable, seperti pada Gambar 1.5. 


$$
\leftrightarrow \text { Choose Variable Result } \Leftrightarrow \text { Print Result to Microsoft Excel }
$$

\section{Choose Categorical Variable (Single Choice) (Group)}

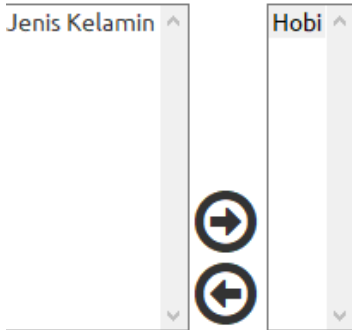

Chroose Categorical Variable (Single Choice)

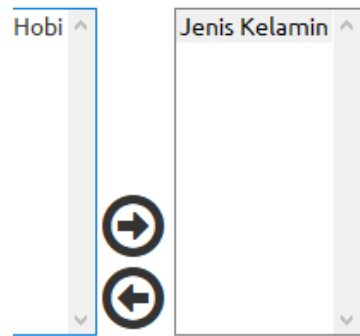

Gambar 1.5 Pemilihan Variabel

Hasil dari grafik lingkaran frekuensi dapat dilihat pada bagian Result (Gambar 1.6).

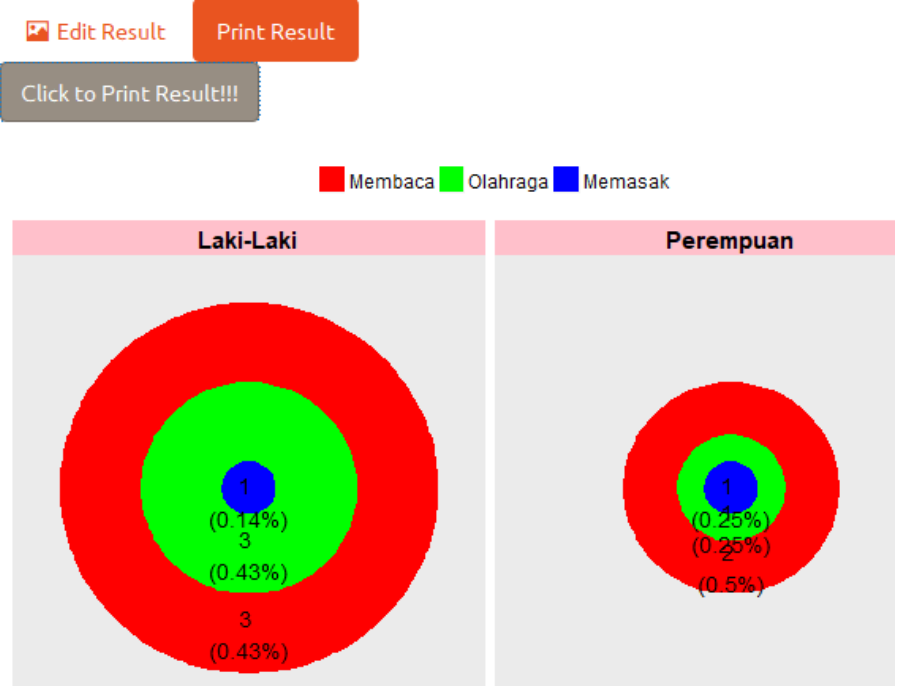

Gambar 1.6 Result 


\title{
Mengolah Data dengan
} Program Aplikasi

\section{Statistika}

Membuat Grafik Sebaran Data dengan Menu

\author{
Boxplot-I
}

Oleh Prana Ugiana Gio

Founder \& CEO STATCAL

Created by Prana Ugiana Gio \& Rezzy Eko Caraka

Boxplot-1
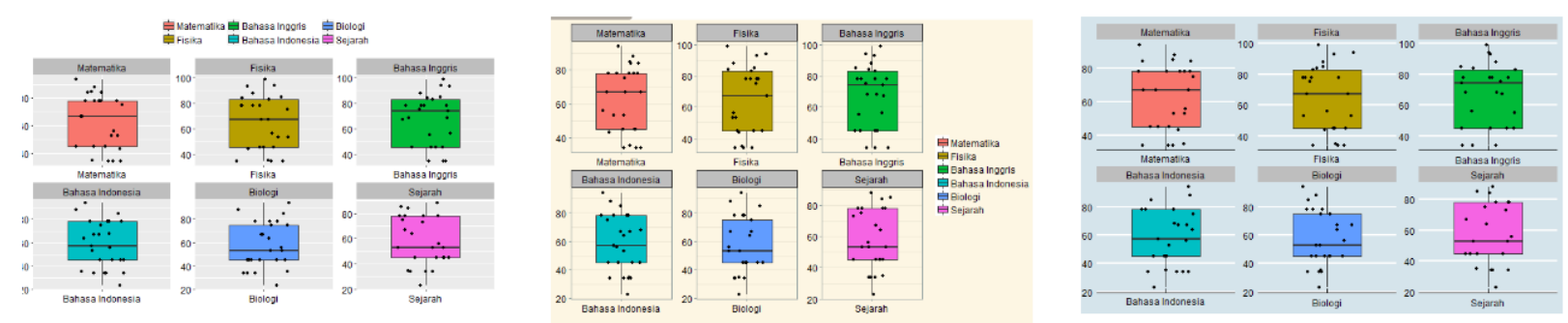
Grafix boxplot dapat digunakan untuk melihat sebaran data terhadap rata-ratanya. Apakah suatu data menyebar cukup jauh atau dekat terhadap rata-ratanya dapat dilihat secara visual melalui grafik boxplot. Gambar 1.1 merupakan grafik boxplot untuk nilai Matematika, Fisika, Bahasa Inggris, Bahasa Indonesia, Biologi dan Sejarah.

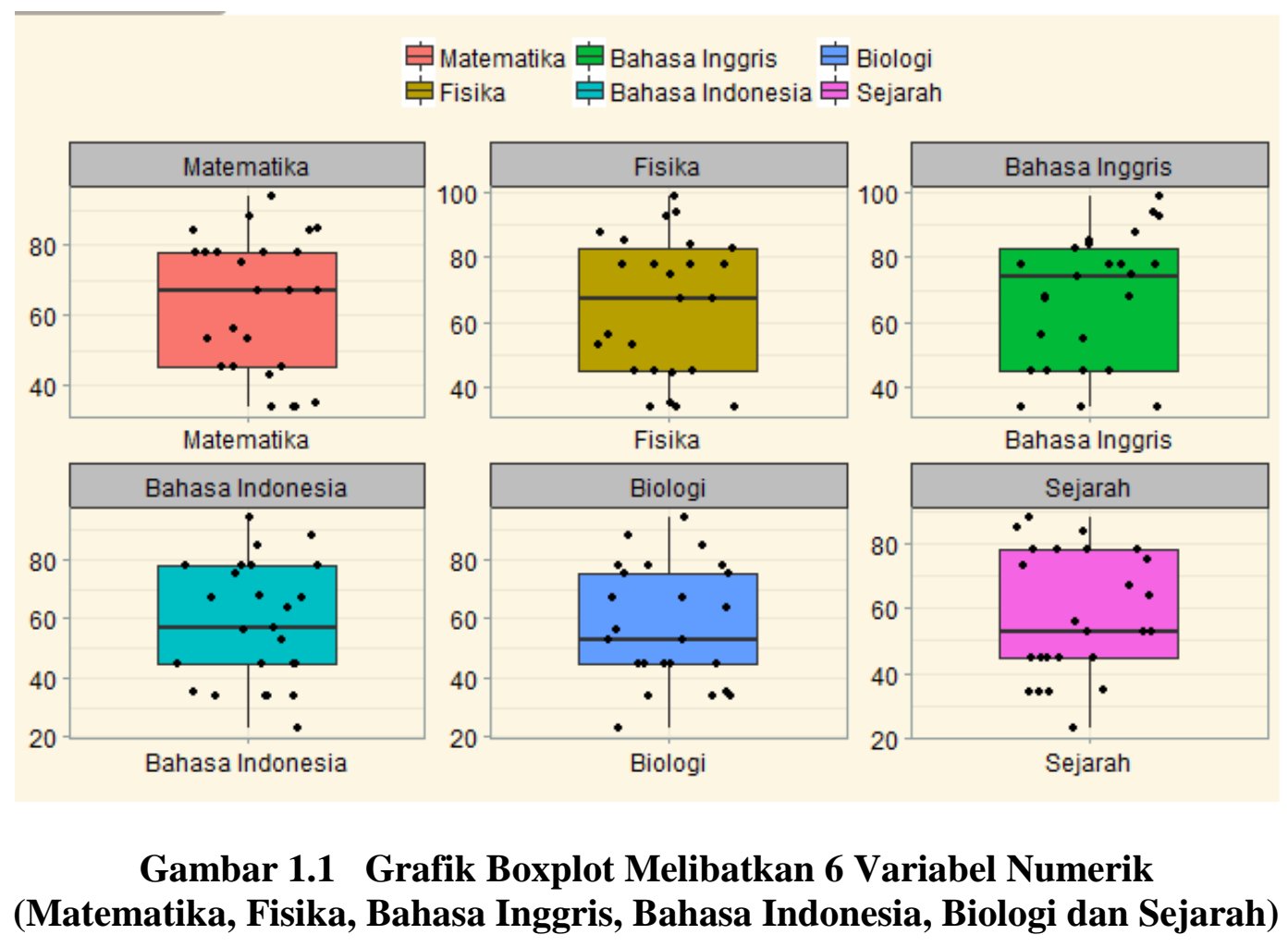

Dari grafik boxplot tersebut, dapat dilihat sebaran data (titik-titik) berdasarkan nilai Matematika, Fisika, Bahasa Inggris, Bahasa Indonesia, Biologi dan Sejarah.

Pada Gambar 1.2, diberikan contoh, pada data nilai Matematika, terdapat data ekstrim (titik yang berwarna merah). 


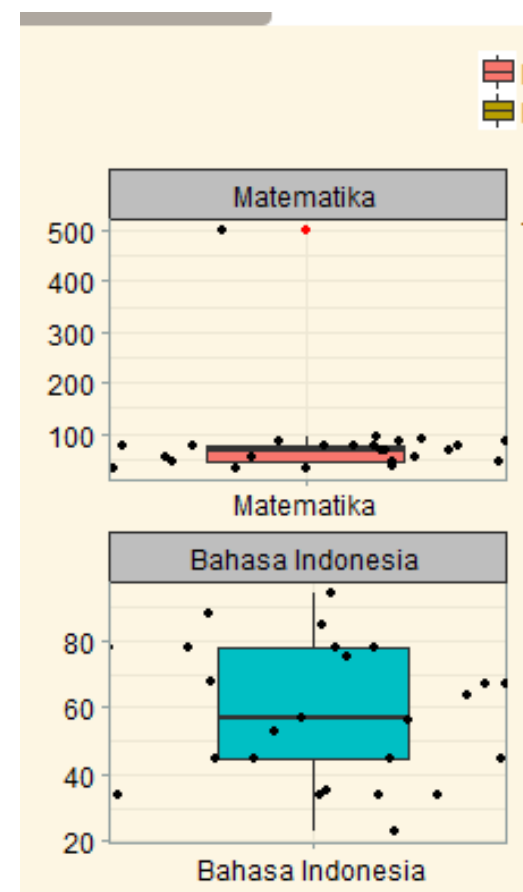

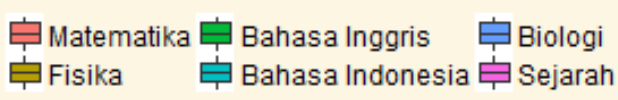
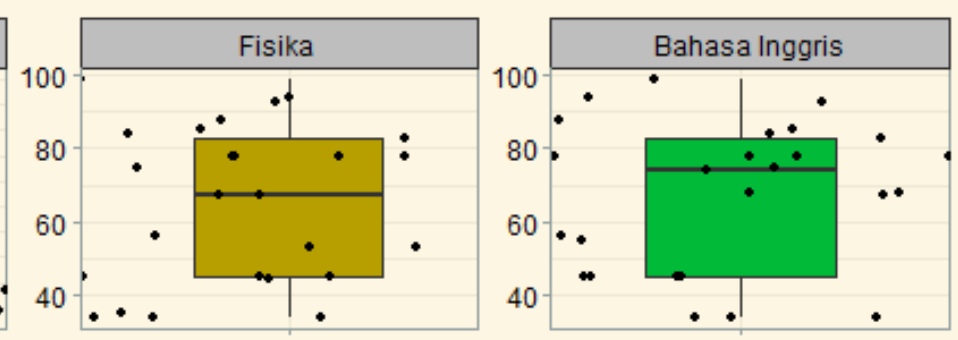

Fisika

Bahasa Inggris
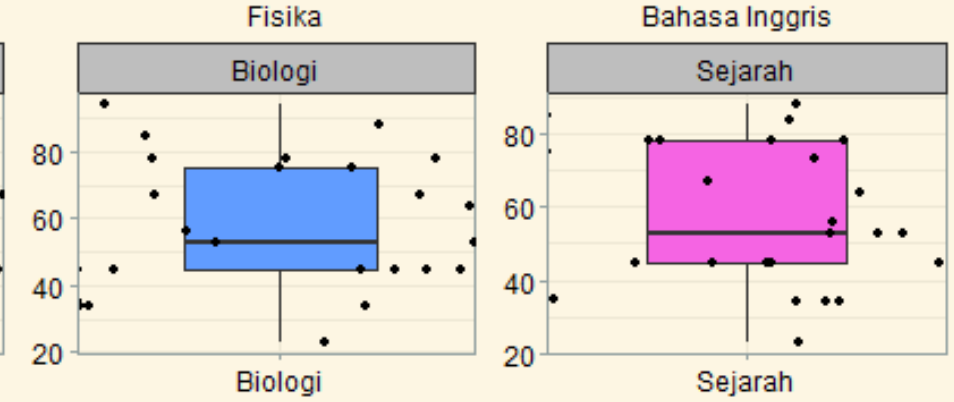

Gambar 1.2 Grafik Boxplot Melibatkan 6 Variabel Numerik (Matematika, Fisika, Bahasa Inggris, Bahasa Indonesia, Biologi dan Sejarah)

Untuk membuat grafik boxplot seperti pada Gambar 1.1, input data pada Tabel 1.1 ke dalam STATCAL, seperti pada Gambar 1.3.

Tabel 1.1 Contoh Data

\begin{tabular}{|c|c|c|c|c|c|}
\hline Matematika & Fisika & Bahasa Inggris & Bahasa Indonesia & Biologi & Sejarah \\
\hline 56 & 56 & 56 & 56 & 56 & 56 \\
\hline 75 & 75 & 75 & 75 & 75 & 75 \\
\hline 45 & 44 & 45 & 45 & 45 & 45 \\
\hline 78 & 88 & 88 & 88 & 88 & 88 \\
\hline 84 & 35 & 74 & 35 & 35 & 35 \\
\hline 43 & 78 & 78 & 78 & 45 & 78 \\
\hline 67 & 34 & 68 & 34 & 34 & 34 \\
\hline 88 & 67 & 55 & 67 & 67 & 67 \\
\hline 35 & 84 & 84 & 64 & 45 & 84 \\
\hline 78 & 53 & 34 & 53 & 53 & 53 \\
\hline 34 & 45 & 45 & 57 & 75 & 45 \\
\hline 67 & 78 & 78 & 78 & 78 & 78 \\
\hline
\end{tabular}




\begin{tabular}{|l|l|l|l|l|l|}
\hline 84 & 53 & 93 & 68 & 23 & 53 \\
\hline 53 & 45 & 99 & 45 & 45 & 45 \\
\hline 45 & 78 & 45 & 78 & 45 & 78 \\
\hline 78 & 34 & 83 & 34 & 34 & 64 \\
\hline 53 & 93 & 68 & 23 & 53 & 53 \\
\hline 45 & 99 & 45 & 45 & 45 & 45 \\
\hline 78 & 45 & 78 & 45 & 78 & 45 \\
\hline 34 & 83 & 34 & 34 & 64 & 34 \\
\hline 67 & 67 & 67 & 67 & 67 & 73 \\
\hline 85 & 85 & 85 & 85 & 85 & 85 \\
\hline 34 & 34 & 34 & 34 & 34 & 34 \\
\hline 78 & 78 & 78 & 78 & 78 & 78 \\
\hline 94 & 94 & 94 & 94 & 94 & 23 \\
\hline
\end{tabular}

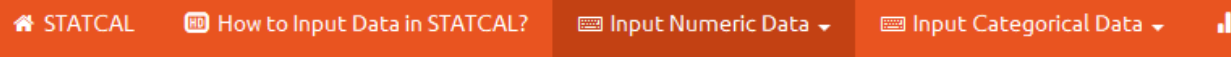

国 Input Numeric Data

\section{Numeric Data}

\begin{tabular}{|c|c|c|c|c|c|c|c|c|c|}
\hline \multirow[b]{2}{*}{ Nanne of Variable } & \multicolumn{9}{|c|}{ Selt Number of Colvoñ } \\
\hline & \multicolumn{9}{|c|}{$\begin{array}{ll}1 & 30 \\
\end{array}$} \\
\hline \multirow{16}{*}{$\begin{array}{l}\text { Matematika } \\
\text { Fisika } \\
\text { Bahasa Inggris } \\
\text { Bahasa Indonesia } \\
\text { Biologi } \\
\text { Sejarah }\end{array}$} & \multicolumn{9}{|c|}{ Selt Number of 'Row } \\
\hline & & $\mathrm{V} 1$ & V2 & V3 & V4 & V5 & V6 & V7 & V8 \\
\hline & 1 & 56.00 & 56.00 & 56.00 & 56.00 & 56.00 & 56.00 & & \\
\hline & 2 & 75.00 & 75.00 & 75.00 & 75.00 & 75.00 & 75.00 & & \\
\hline & 3 & 45.00 & 44.00 & 45.00 & 45.00 & 45.00 & 45.00 & & \\
\hline & 4 & 78.00 & 88.00 & 88.00 & 88.00 & 88.00 & 88.00 & & \\
\hline & 5 & 84.00 & 35.00 & 74.00 & 35.00 & 35.00 & 35.00 & & \\
\hline & 6 & 43.00 & 78.00 & 78.00 & 78.00 & 45.00 & 78.00 & & \\
\hline & 7 & 67.00 & 34.00 & 68.00 & 34.00 & 34.00 & 34.00 & & \\
\hline & 8 & 88.00 & 67.00 & 55.00 & 67.00 & 67.00 & 67.00 & & \\
\hline & 9 & 35.00 & 84.00 & 84.00 & 64.00 & 45.00 & 84.00 & & \\
\hline & 10 & 78.00 & 53.00 & 34.00 & 53.00 & 53.00 & 53.00 & & \\
\hline & 11 & 34.00 & 45.00 & 45.00 & 57.00 & 75.00 & 45.00 & & \\
\hline & 12 & 67.00 & 78.00 & 78.00 & 78.00 & 78.00 & 78.00 & & \\
\hline & 13 & 84.00 & 53.00 & 93.00 & 68.00 & 23.00 & 53.00 & & \\
\hline & 14 & $53 \mathrm{n}$ & $45 \mathrm{n}$ & ח९ & $45 \cap 0$ & $45 \cap 0$ & $45 \mathrm{n}$ & & \\
\hline
\end{tabular}

Gambar 1.3 Input Data Numerik

Selanjutnya pilih Graph => Boxplot (Gambar 1.4). 


\section{ll Graph v}
Wlll Bar
L Line
Circle
Boxplot

\section{Gambar 1.4 Menu Boxplot}

Pilih menu Boxplot-I (Gambar 1.5).

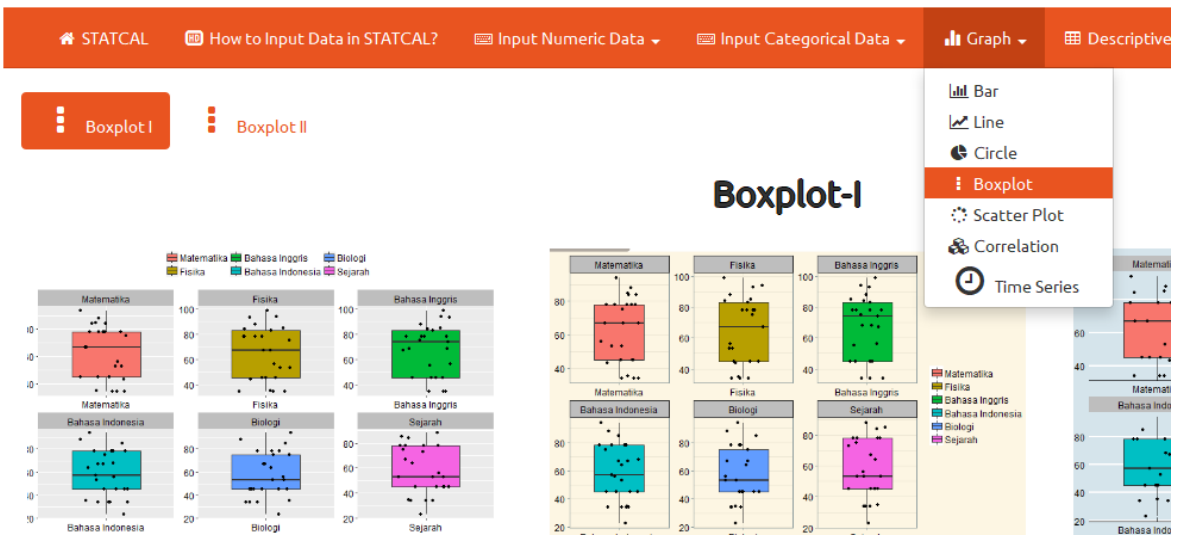

Gambar 1.5 Menu Boxplot-I

Lakukan pemilihan variabel pada bagian Choose Variable (Gambar 1.6).

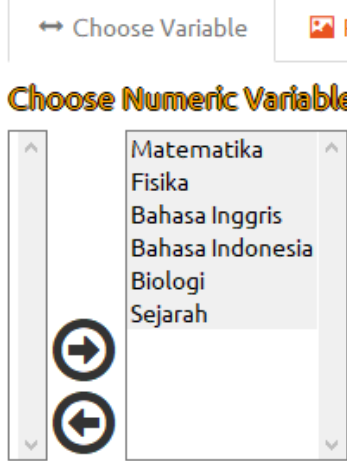

Gambar 1.6 Pemilihan Variabel 
Hasil dari grafik boxplot dapat dilihat pada bagian Result (Gambar 1.7).
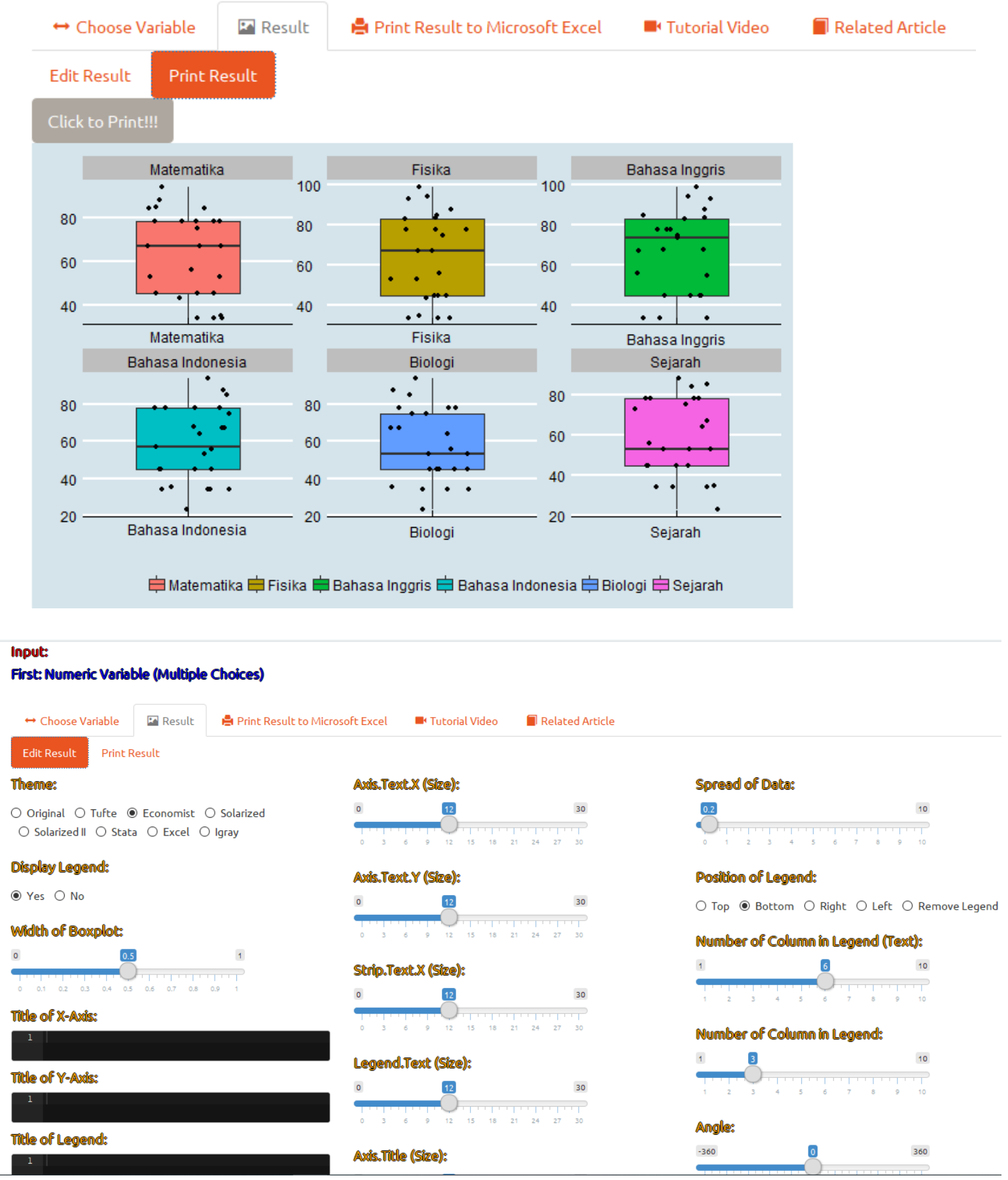

Gambar 1.7 Result 


\section{Mengolah Data dengan} Program Aplikasi Statistika
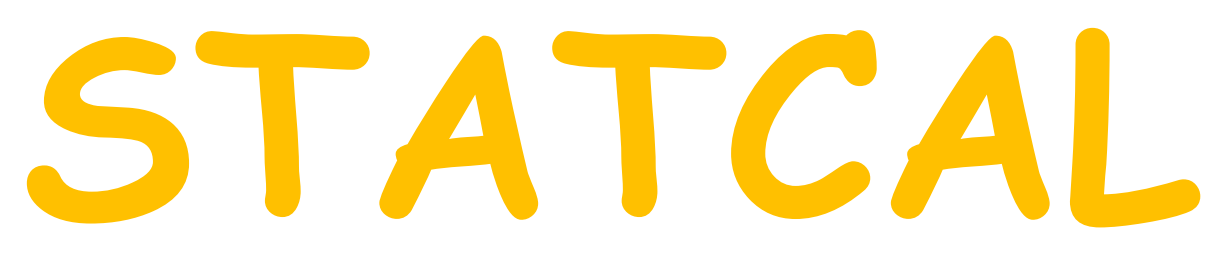

Membuat Grafik Sebaran Data dengan Menu

$$
\text { Boxplot-II }
$$

Oleh Prana Ugiana Gio

Founder \& CEO STATCAL

Created by Prana Ugiana Gio \& Rezzy Eko Caraka

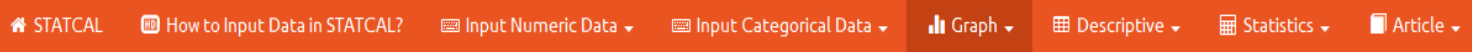

\section{Boxplotl : Boxplotll}

\section{Boxplot-II}
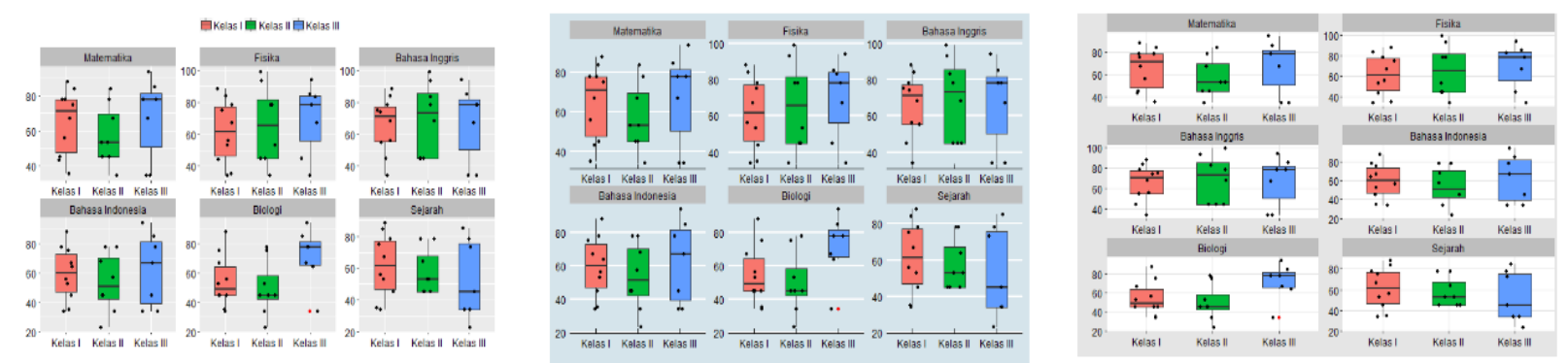
Grafix boxplot dapat digunakan untuk melihat sebaran data terhadap rata-ratanya. Apakah suatu data menyebar cukup jauh atau dekat terhadap rata-ratanya dapat dilihat secara visual melalui grafik boxplot. Gambar 1.1 merupakan grafik boxplot untuk nilai Matematika, Fisika, Bahasa Inggris, Bahasa Indonesia, Biologi dan Sejarah berdasarkan Kelas I, Kelas II dan Kelas III.

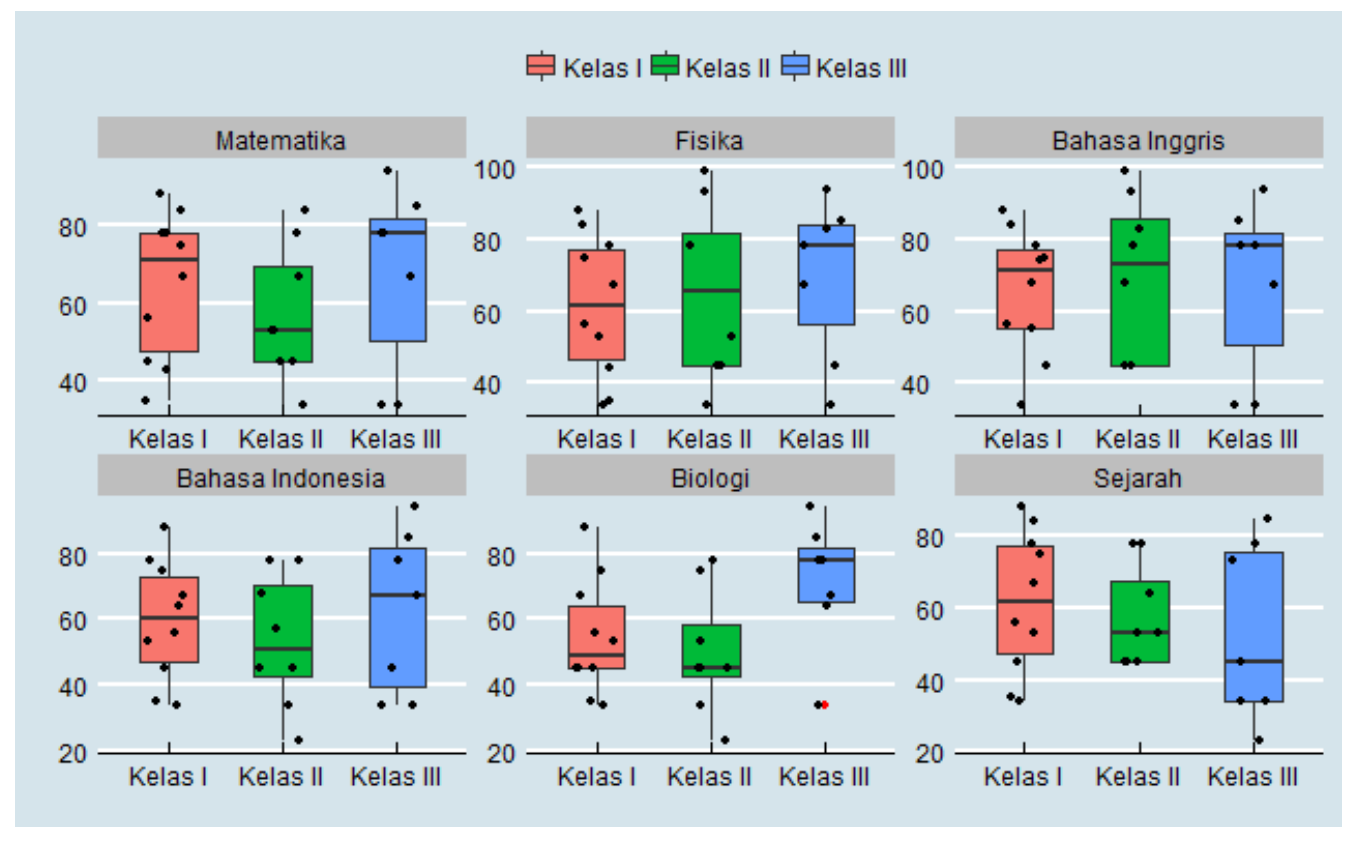

\section{Gambar 1.1 Grafik Boxplot}

Pada Gambar 1.2, diberikan contoh, pada data nilai Matematika, Kelas I, terdapat data ekstrim (titik yang berwarna merah). 


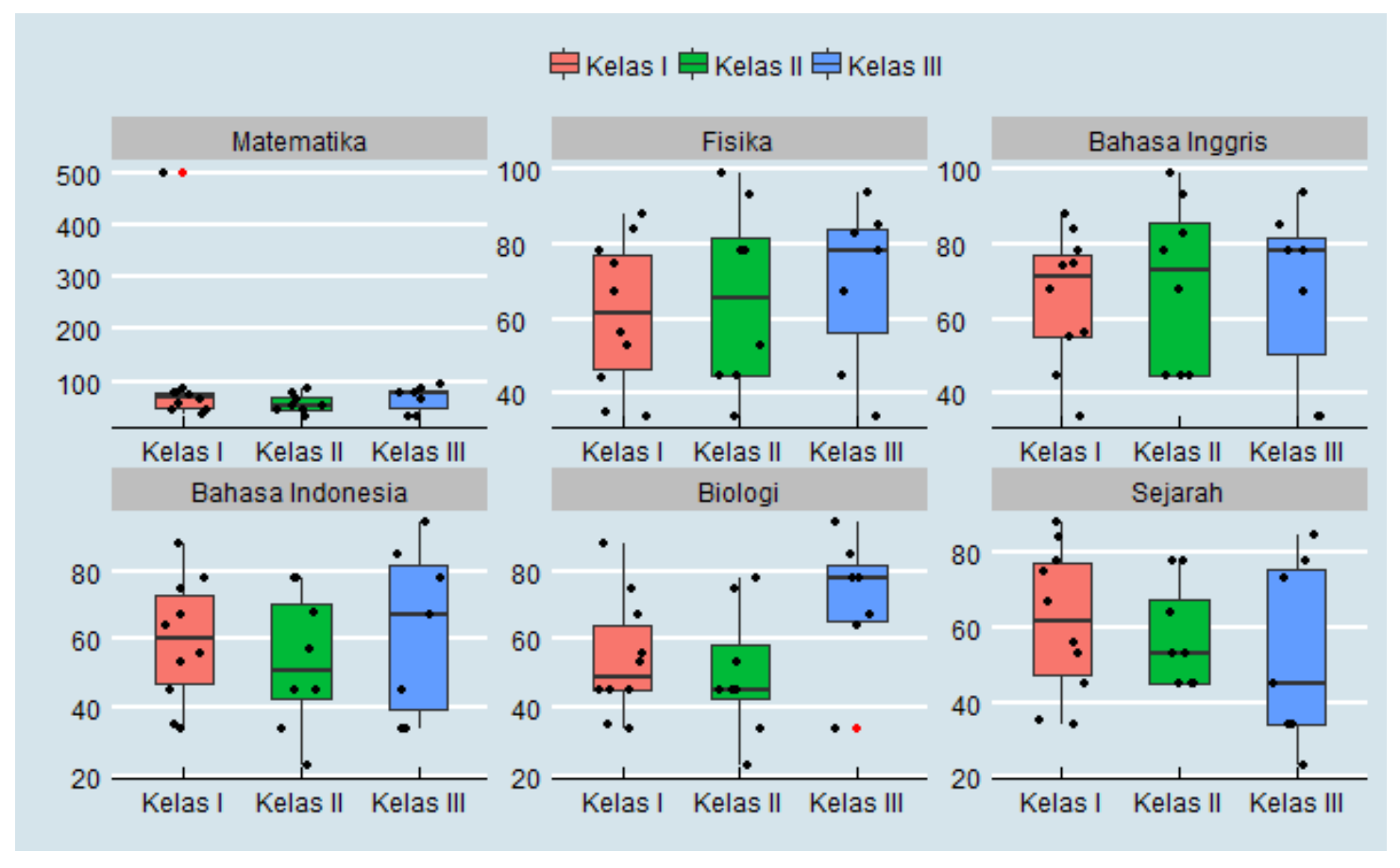

Gambar 1.2

Untuk membuat grafik boxplot seperti pada Gambar 1.1, input data pada Tabel 1.1 ke dalam STATCAL, seperti pada Gambar 1.3 (input data numerik) dan Gambar 1.4 (input data kategori).

Tabel 1.1 Contoh Data

\begin{tabular}{|c|c|c|c|c|c|c|}
\hline Kelas & Matematika & Fisika & Bahasa Inggris & Bahasa Indonesia & Biologi & Sejarah \\
\hline 1 & 56 & 56 & 56 & 56 & 56 & 56 \\
\hline 1 & 75 & 75 & 75 & 75 & 75 & 75 \\
\hline 1 & 45 & 44 & 45 & 45 & 45 & 45 \\
\hline 1 & 78 & 88 & 88 & 88 & 88 & 88 \\
\hline 1 & 84 & 35 & 74 & 35 & 35 & 35 \\
\hline 1 & 43 & 78 & 78 & 78 & 45 & 78 \\
\hline 1 & 67 & 34 & 68 & 34 & 34 & 34 \\
\hline 1 & 88 & 67 & 55 & 67 & 67 & 67 \\
\hline 1 & 35 & 84 & 84 & 64 & 45 & 84 \\
\hline 1 & 78 & 53 & 34 & 53 & 53 & 53 \\
\hline 2 & 34 & 45 & 45 & 57 & 75 & 45 \\
\hline 2 & 67 & 78 & 78 & 78 & 78 & 78 \\
\hline 2 & 84 & 53 & 93 & 68 & 23 & 53 \\
\hline
\end{tabular}




\begin{tabular}{|l|l|l|l|l|l|l|}
2 & 53 & 45 & 99 & 45 & 45 & 45 \\
\hline 2 & 45 & 78 & 45 & 78 & 45 & 78 \\
\hline 2 & 78 & 34 & 83 & 34 & 34 & 64 \\
\hline 2 & 53 & 93 & 68 & 23 & 53 & 53 \\
\hline 2 & 45 & 99 & 45 & 45 & 45 & 45 \\
\hline 3 & 78 & 45 & 78 & 45 & 78 & 45 \\
\hline 3 & 34 & 83 & 34 & 34 & 64 & 34 \\
\hline 3 & 67 & 67 & 67 & 67 & 67 & 73 \\
\hline 3 & 85 & 85 & 85 & 85 & 85 & 85 \\
\hline 3 & 34 & 34 & 34 & 34 & 34 & 34 \\
\hline 3 & 78 & 78 & 78 & 78 & 78 & 78 \\
\hline 3 & 94 & 94 & 94 & 94 & 94 & 23 \\
\hline
\end{tabular}

\begin{tabular}{|c|c|}
\hline Angka & Kelas \\
\hline 1 & Kelas I \\
\hline 2 & Kelas II \\
\hline 3 & Kelas III \\
\hline
\end{tabular}

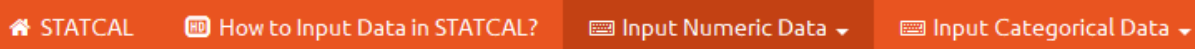

Numeric Data

\begin{tabular}{|c|c|c|c|c|c|c|c|c|c|}
\hline \multirow{2}{*}{ Nanne of Variable } & \multicolumn{9}{|c|}{ Sett Nuñber of Columon } \\
\hline & \multicolumn{4}{|c|}{ Sett Nuniber of Row } & \multicolumn{4}{|c|}{$\begin{array}{ll}1 & 30\end{array}$} & \\
\hline \multirow{13}{*}{$\begin{array}{l}\text { Matematika } \\
\text { Fisika } \\
\text { Bahasa Inggris } \\
\text { Bahasa Indonesia } \\
\text { Biologi } \\
\text { Sejarah }\end{array}$} & \multicolumn{9}{|c|}{$1 \quad 100$} \\
\hline & & V1 & V2 & V3 & V4 & V5 & V6 & V7 & V8 \\
\hline & 1 & 56.00 & 56.00 & 56.00 & 56.00 & 56.00 & 56.00 & & \\
\hline & 2 & 75.00 & 75.00 & 75.00 & 75.00 & 75.00 & 75.00 & & \\
\hline & 3 & 45.00 & 44.00 & 45.00 & 45.00 & 45.00 & 45.00 & & \\
\hline & 4 & 78.00 & 88.00 & 88.00 & 88.00 & 88.00 & 88.00 & & \\
\hline & 5 & 84.00 & 35.00 & 74.00 & 35.00 & 35.00 & 35.00 & & \\
\hline & 6 & 43.00 & 78.00 & 78.00 & 78.00 & 45.00 & 78.00 & & \\
\hline & 7 & 67.00 & 34.00 & 68.00 & 34.00 & 34.00 & 34.00 & & \\
\hline & 8 & 88.00 & 67.00 & 55.00 & 67.00 & 67.00 & 67.00 & & \\
\hline & 9 & 35.00 & 84.00 & 84.00 & 64.00 & 45.00 & 84.00 & & \\
\hline & 10 & 78.00 & 53.00 & 34.00 & 53.00 & 53.00 & 53.00 & & \\
\hline & 11 & 34.00 & 45.00 & 45.00 & 57.00 & 75.00 & 45.00 & & \\
\hline
\end{tabular}

Gambar 1.3 Input Data Numerik 


\section{Categorical Data}

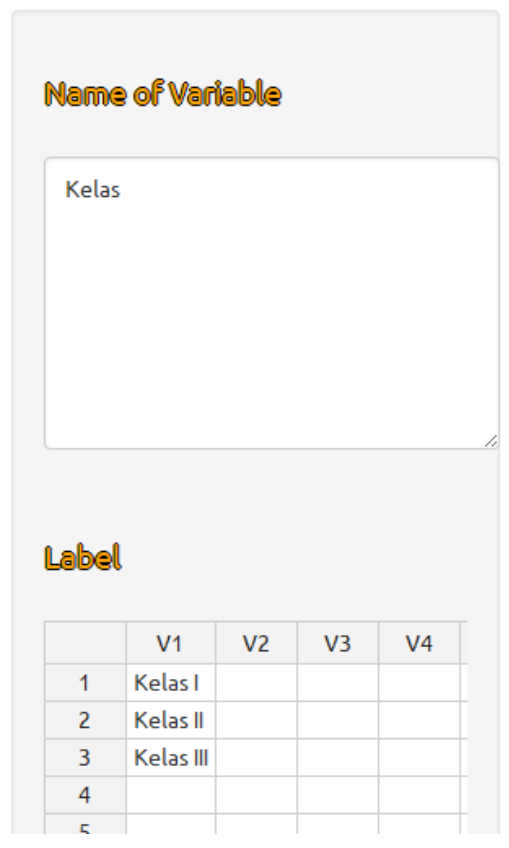

\section{selt Nunnber of Columo}
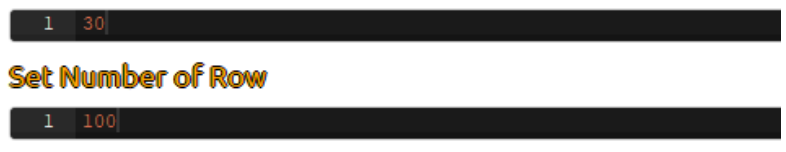

\begin{tabular}{|c|c|c|c|c|c|c|c|c|c|}
\hline & V1 & V2 & V3 & V4 & V5 & V6 & V7 & V8 & V \\
\hline 1 & 1.00 & & & & & & & & \\
\hline 2 & 1.00 & & & & & & & & \\
\hline 3 & 1.00 & & & & & & & & \\
\hline 4 & 1.00 & & & & & & & & \\
\hline 5 & 1.00 & & & & & & & & \\
\hline 6 & 1.00 & & & & & & & & \\
\hline 7 & 1.00 & & & & & & & & \\
\hline 8 & 1.00 & & & & & & & & \\
\hline 9 & 1.00 & & & & & & & & \\
\hline 10 & 1.00 & & & & & & & & \\
\hline 11 & 2.00 & & & & & & & & \\
\hline 12 & 2.00 & & & & & & & & \\
\hline 13 & 2.00 & & & & & & & & \\
\hline 14 & 2.00 & & & & & & & & \\
\hline 15 & 2.00 & & & & & & & & \\
\hline
\end{tabular}

\section{Gambar 1.4 Input Data Kategori}

Selanjutnya pilih Graph => Boxplot (Gambar 1.5).

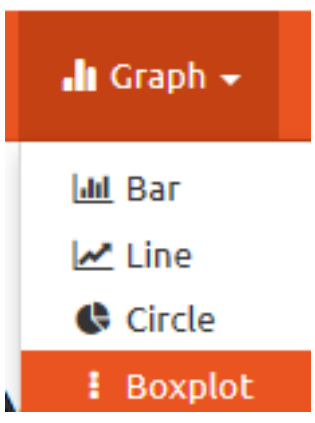

Gambar 1.5 Menu Boxplot

Pilih menu Boxplot-I (Gambar 1.6). 


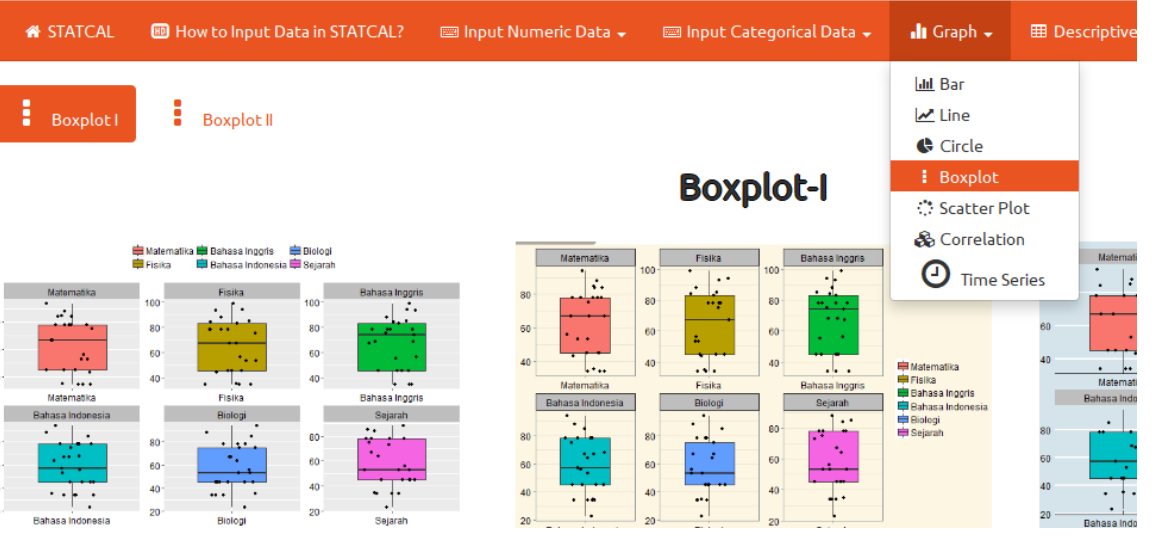

Gambar 1.6 Menu Boxplot-I

Lakukan pemilihan variabel pada bagian Choose Variable (Gambar 1.7).

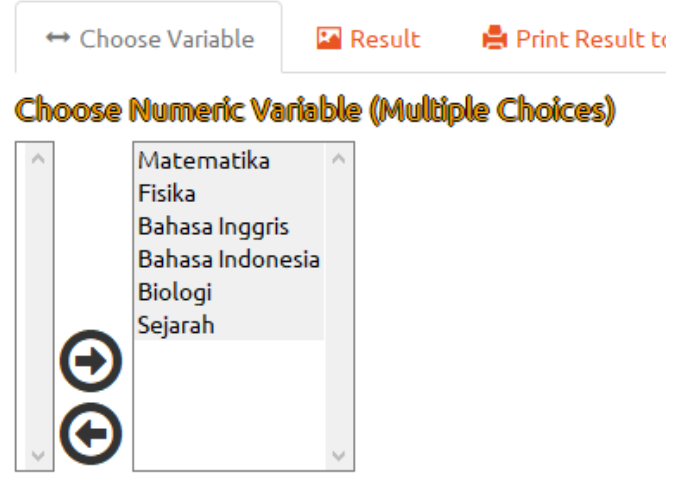

Gambar 1.7 Pemilihan Variabel

Hasil dari grafik boxplot dapat dilihat pada bagian Result (Gambar 1.8). 


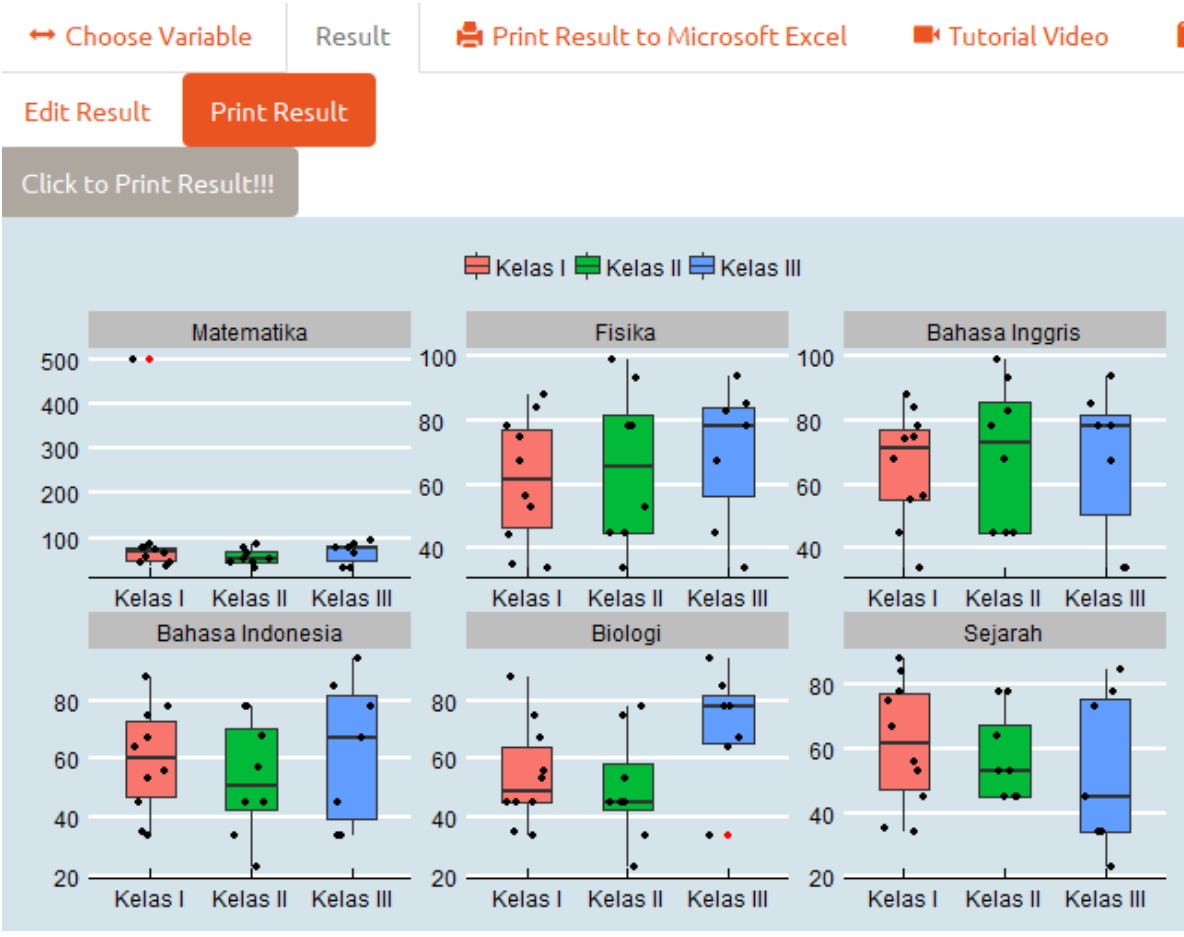

Gambar 1.8 Result 


\title{
Mengolah Data dengan Program Aplikasi Statistika
}

Membuat Grafik Korelasi dengan Menu

\author{
Correlation-I
}

Oleh Prana Ugiana Gio

Founder \& CEO STATCAL

Created by Prana Ugiana Gio \& Rezzy Eko Caraka

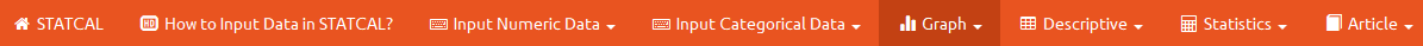

3 Correlation-1

Correlation-I
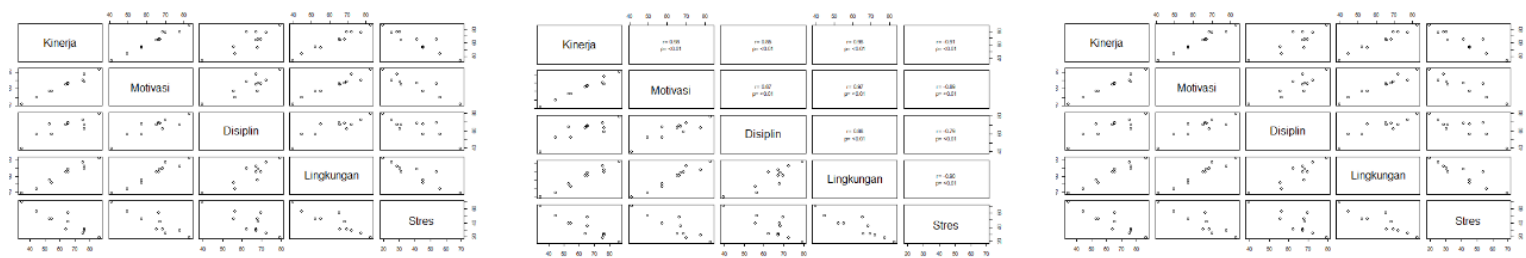
Misalkan diberikan contoh data seperti pada Tabel 1.1.

Tabel 1.1 Contoh Data

\begin{tabular}{|c|c|c|c|c|c|}
\hline No & Kinerja & Motivasi & Stres & Gaji & Berat Badan \\
\hline 1 & 75 & 71 & 45 & 74 & 55.34 \\
\hline 2 & 65 & 60 & 65 & 67 & 65.34 \\
\hline 3 & 72 & 78 & 55 & 70 & 45.45 \\
\hline 4 & 84 & 79 & 55 & 80 & 71.21 \\
\hline 5 & 74 & 69 & 54 & 74 & 54.45 \\
\hline 6 & 59 & 55 & 76 & 59 & 48.53 \\
\hline 7 & 83 & 80 & 37 & 80 & 76.45 \\
\hline 8 & 55 & 45 & 75 & 52 & 76.45 \\
\hline 9 & 65 & 78 & 68 & 67 & 56.43 \\
\hline 10 & 73 & 77 & 54 & 70 & 63.34 \\
\hline
\end{tabular}

Dengan menggunakan menu Correlation-I, disajikan grafik seperti pada Gambar 1.1.

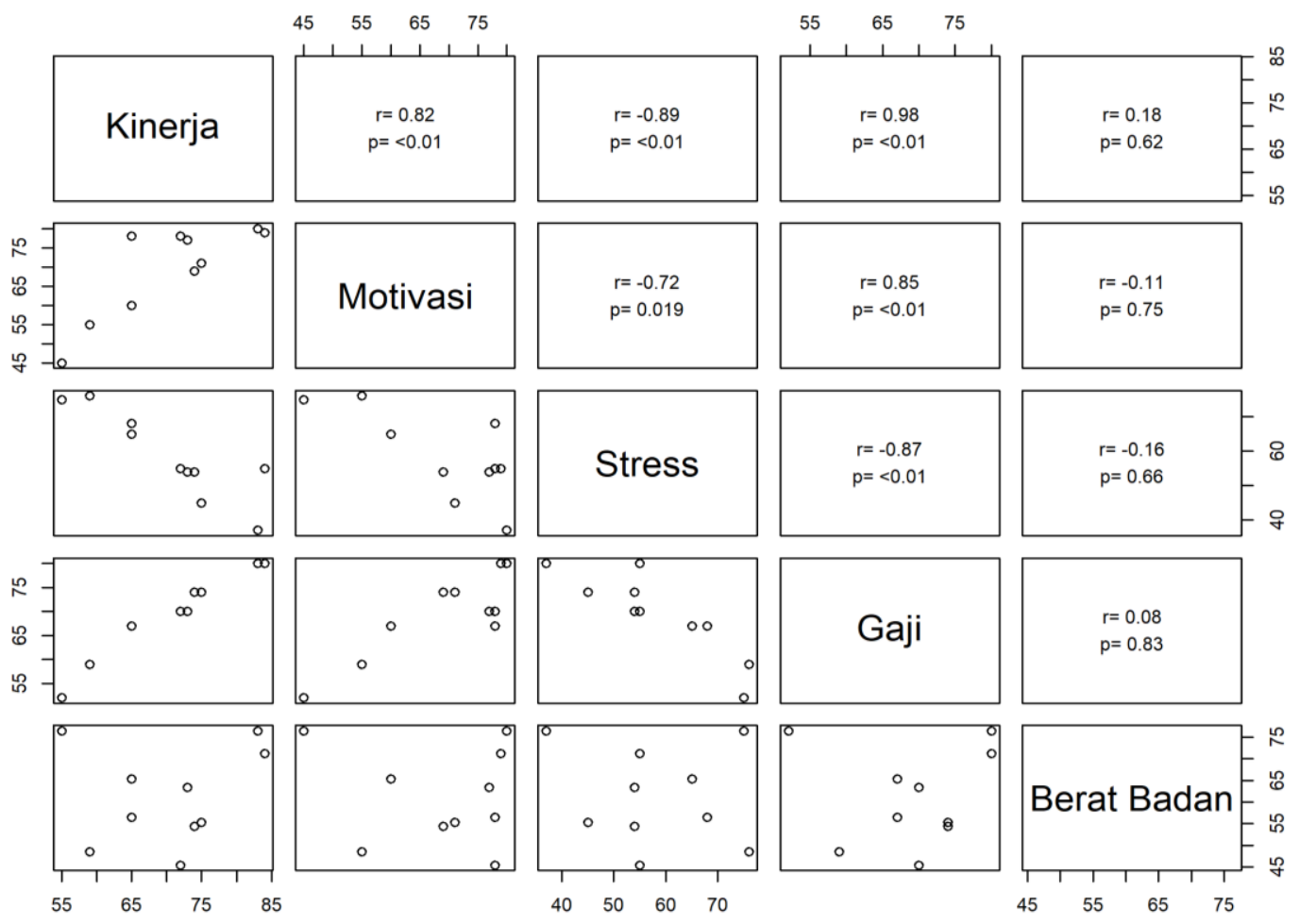

Gambar 1.1 Grafik Sebaran Data beserta Nilai Korelasi Pearson 
Gambar 1.1 merupakan grafik sebaran data untuk setiap dua variabel, beserta nilai korelasi Pearson. Sebagai contoh:

$\Rightarrow$ Pada Gambar 1.1, dapat dilihat sebaran data dua variabel, yakni antara variabel motivasi dan kinerja. Terlihat nilai korelasi Pearson sebesar 0,82, dengan p-value $<0.01$.

$\Rightarrow$ Pada Gambar 1.1, dapat dilihat sebaran data dua variabel, yakni antara variabel motivasi dan stress. Terlihat nilai korelasi Pearson sebesar $-0,72$, dengan $p$-value $=0,019$, dan seterusnya.

Untuk membuat grafik seperti pada Gambar 1.1, input data numerik, seperti pada Gambar 1.2.

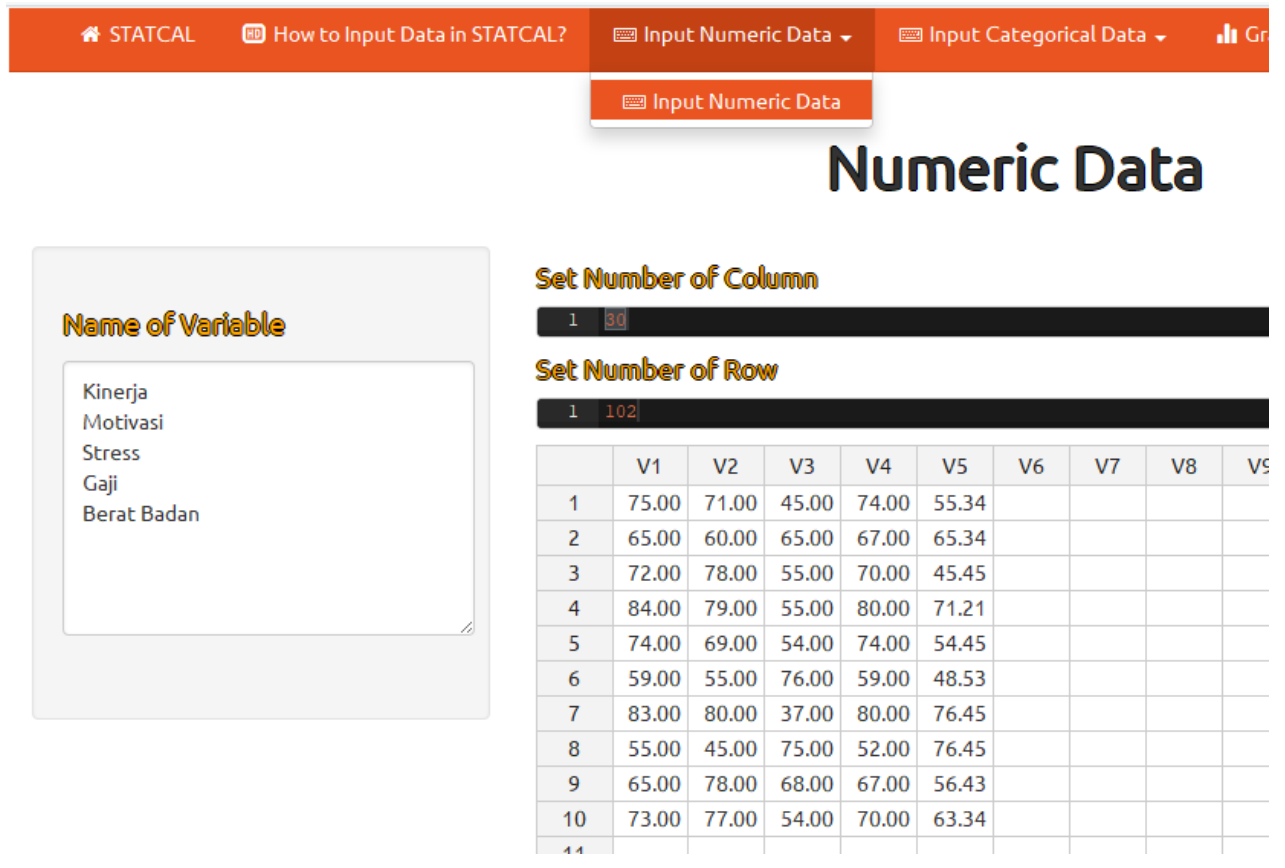

Gambar 1.2 Input Data Numerik

Selanjutnya pilih Graph => Correlation (Gambar 1.3). 


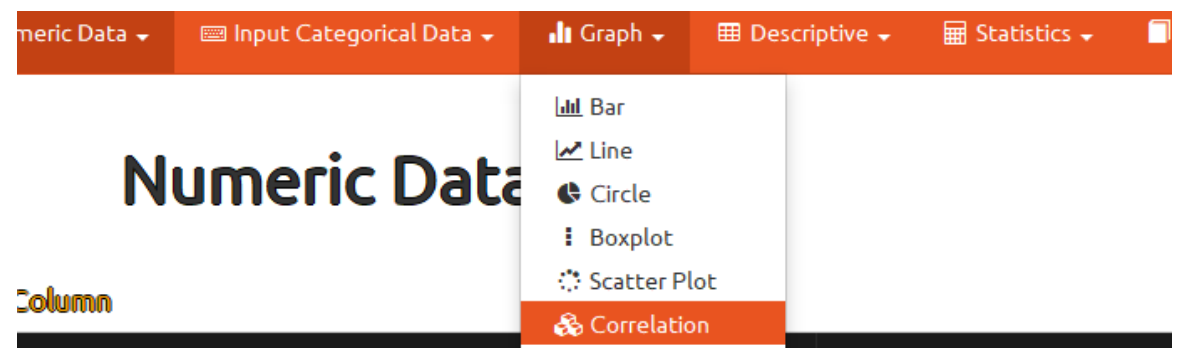

\section{Gambar 1.3 Menu Correlation}

Pilih menu Correlation-I (Gambar 1.4).

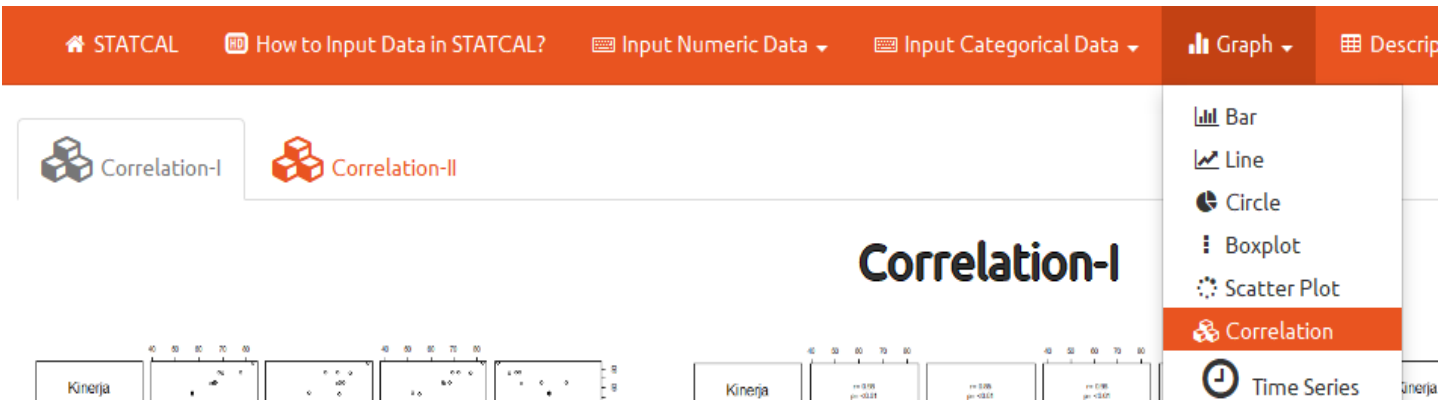

Gambar 1.4 Menu Correlation-I

Lakukan pemilihan variabel seperti pada Gambar 1.5.

Input:

First: Numeric Variable (Multiple Choices)

$\leftrightarrow$ Choose Variable Result $\quad$ Print Result to Microso

Choose Nunieric Variable (Mulliolple Choices)

$\rightarrow \mid$\begin{tabular}{|l|l|}
\hline Kinerja \\
Motivasi \\
Stress \\
Gaji \\
Berat Badan
\end{tabular}

Gambar 1.5 Pemilihan Variabel 
Hasil dari grafik dapat dilihat pada bagian Result (Gambar 1.6).
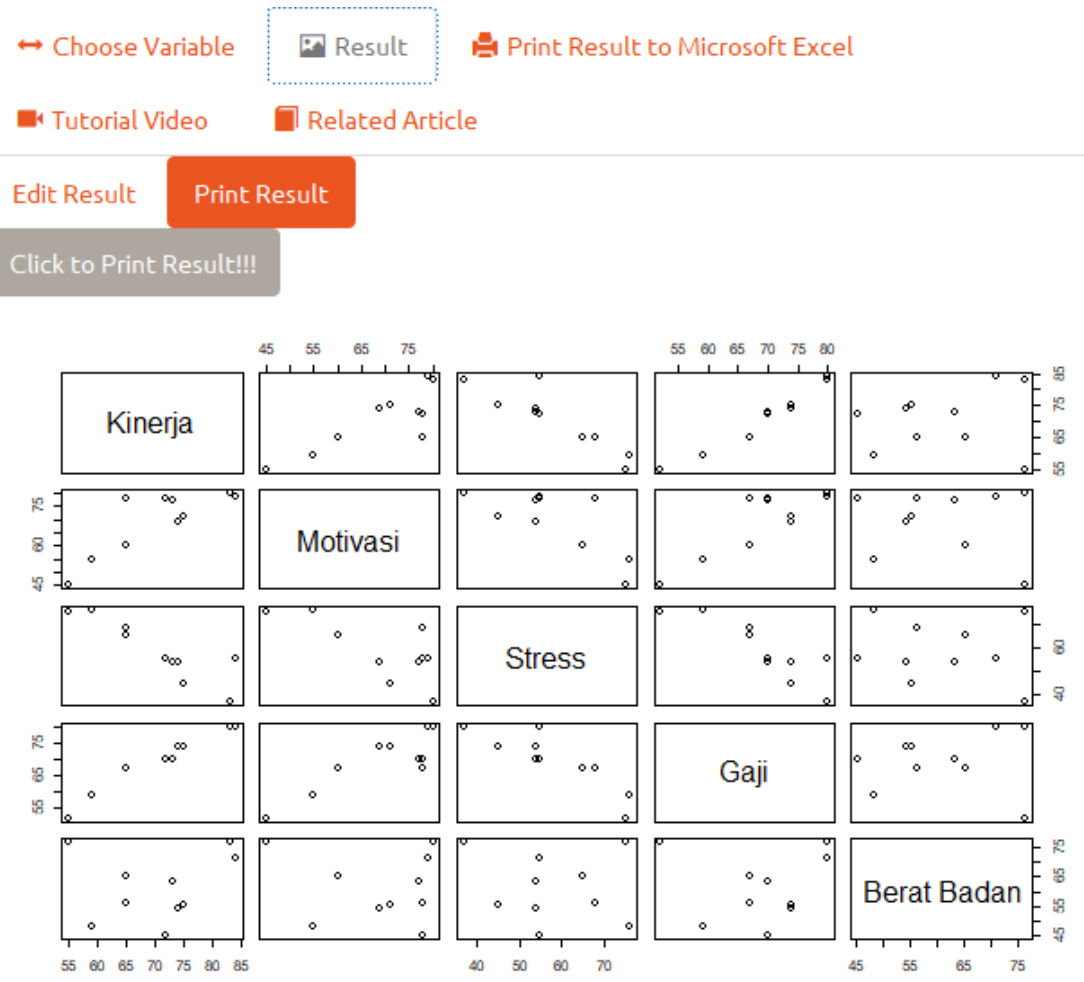

Gambar 1.6 Result 


\section{Mengolah Data dengan}

Program Aplikasi Statistika

Membuat Grafik Korelasi dengan Menu

\section{Correlation-II}

\section{Oleh Prana Ugiana Gio}

Founder \& CEO STATCAL

Created by Prana Ugiana Gio \& Rezzy Eko Caraka

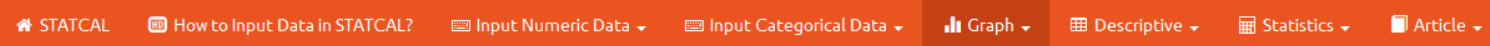

3 Correlation-1 3 Correlation-ll

Correlation-II
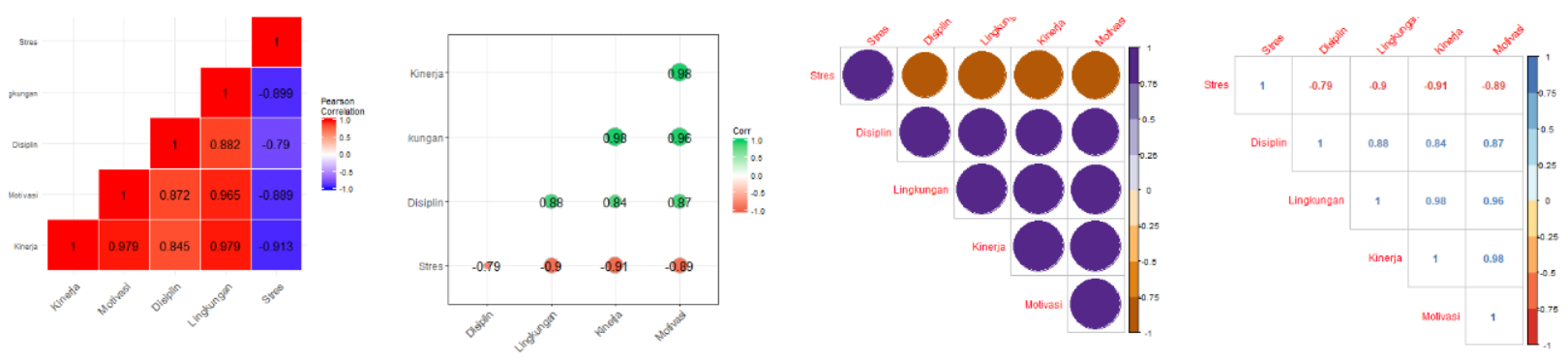
Misalkan diberikan contoh data seperti pada Tabel 1.1.

Tabel 1.1 Contoh Data

\begin{tabular}{|c|c|c|c|c|c|}
\hline No & Kinerja & Motivasi & Stres & Gaji & Berat Badan \\
\hline 1 & 75 & 71 & 45 & 74 & 55.34 \\
\hline 2 & 65 & 60 & 65 & 67 & 65.34 \\
\hline 3 & 72 & 78 & 55 & 70 & 45.45 \\
\hline 4 & 84 & 79 & 55 & 80 & 71.21 \\
\hline 5 & 74 & 69 & 54 & 74 & 54.45 \\
\hline 6 & 59 & 55 & 76 & 59 & 48.53 \\
\hline 7 & 83 & 80 & 37 & 80 & 76.45 \\
\hline 8 & 55 & 45 & 75 & 52 & 76.45 \\
\hline 9 & 65 & 78 & 68 & 67 & 56.43 \\
\hline 10 & 73 & 77 & 54 & 70 & 63.34 \\
\hline
\end{tabular}

Dengan menggunakan menu Correlation-II, disajikan grafik korelasi Pearson antar variabel seperti pada Gambar 1.1 sampai Gambar 1.5.

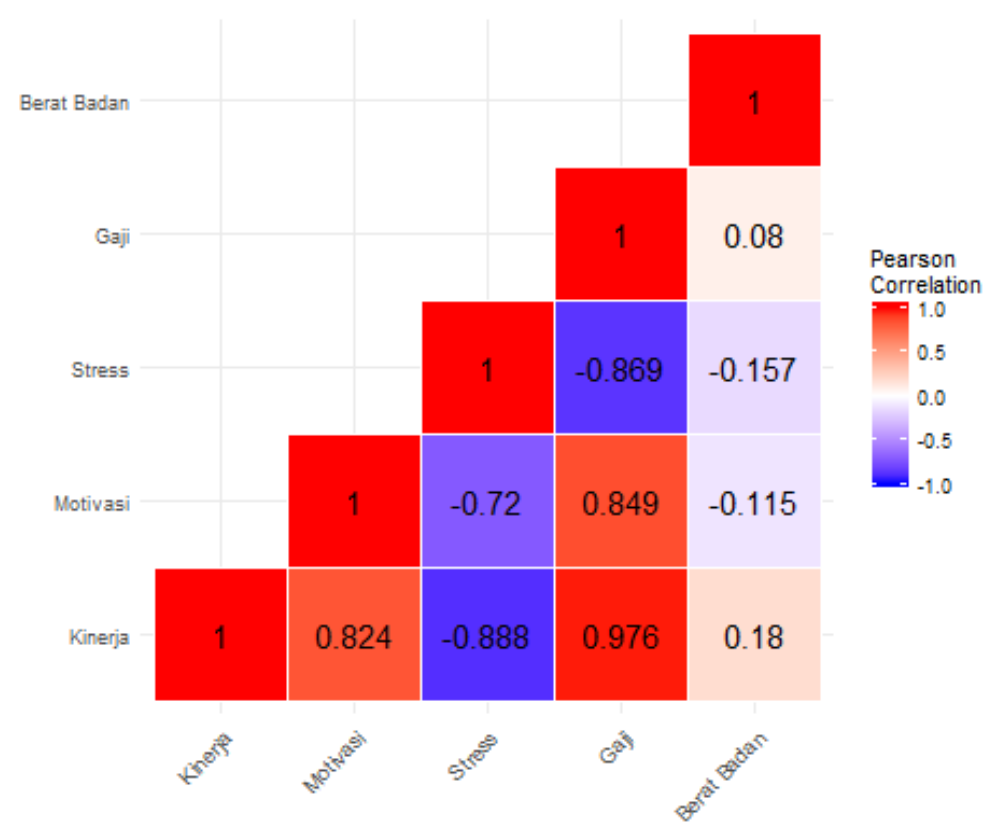

Gambar 1.1 Grafik Korelasi Pearson antar Variabel 


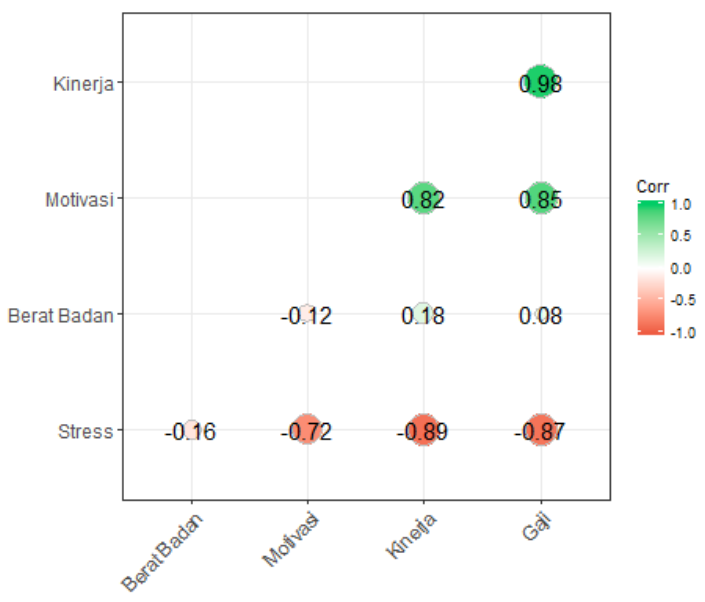

Gambar 1.2 Grafik Korelasi Pearson antar Variabel

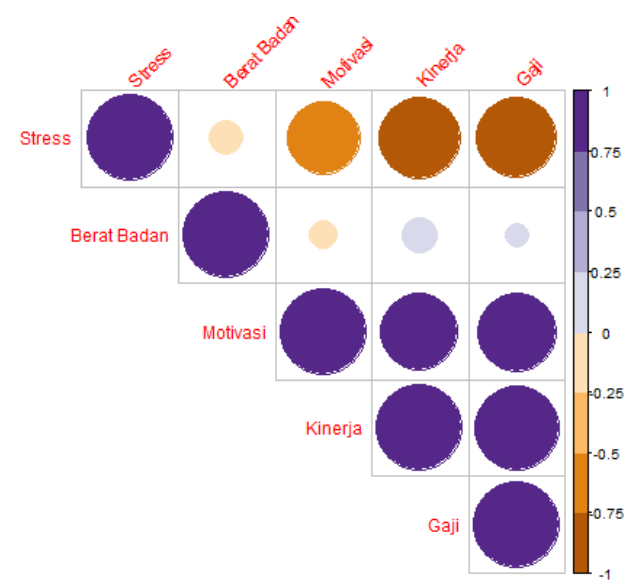

Gambar 1.3 Grafik Korelasi Pearson antar Variabel

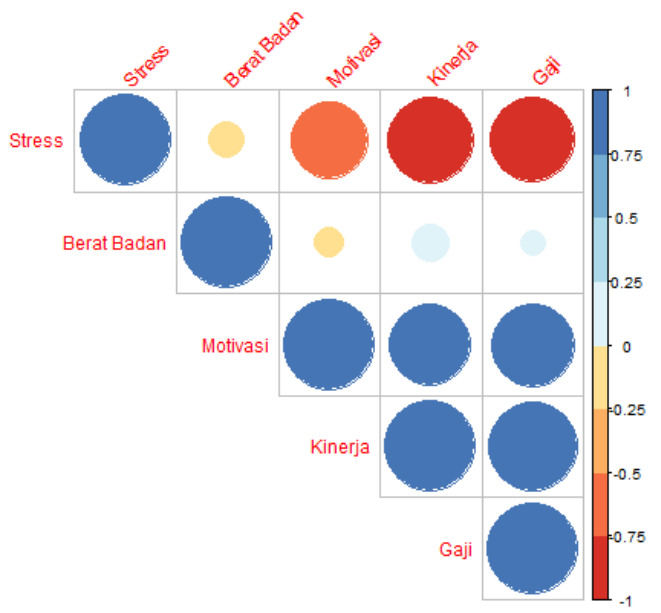

Gambar 1.4 Grafik Korelasi Pearson antar Variabel 


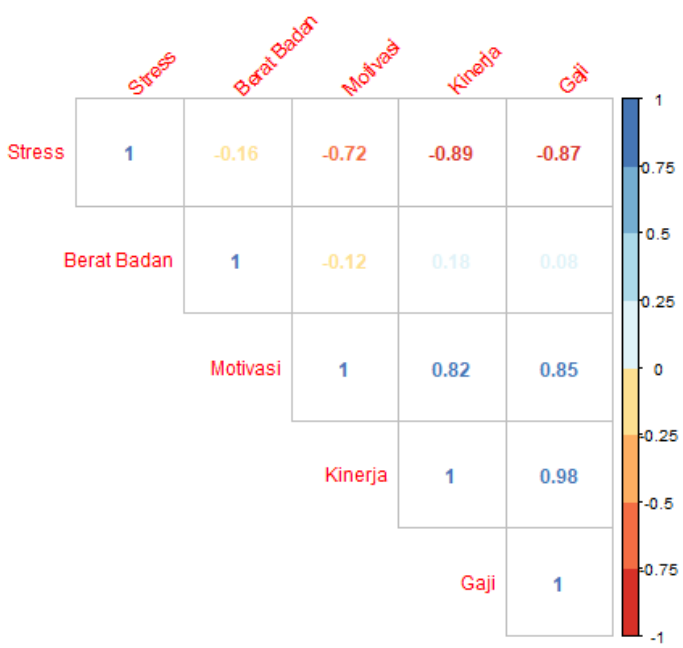

\section{Gambar 1.5 Grafik Korelasi Pearson antar Variabel}

Berdasarkan Gambar 1.1, diketahui:

$\Rightarrow$ Nilai korelasi Pearson antara motivasi dan kinerja sebesar 0,824.

$\Rightarrow$ Nilai korelasi Pearson antara stress dan kinerja sebesar -0,888, dan seterusnya.

Untuk membuat grafik korelasi seperti pada Gambar 1.1 sampai Gambar 1.5, input data numerik, seperti pada Gambar 1.6.

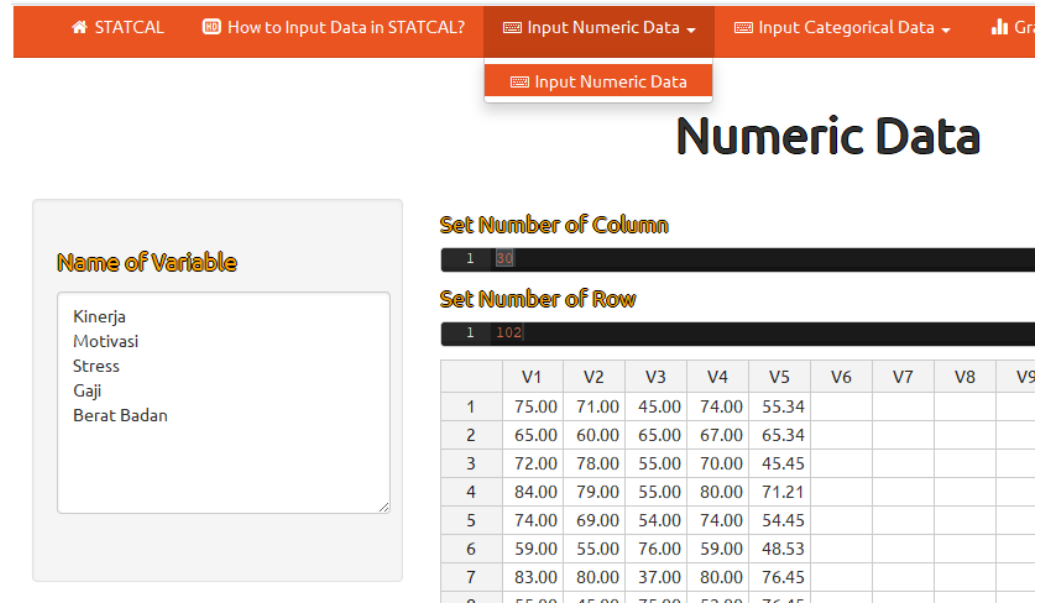

Gambar 1.6 Input Data Numerik 
Selanjutnya pilih Graph => Correlation (Gambar 1.7).

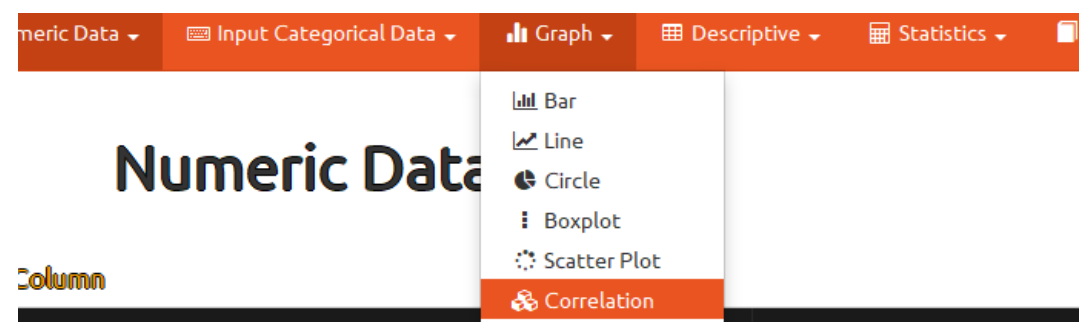

\section{Gambar 1.7 Menu Correlation}

Pilih menu Correlation-I (Gambar 1.8).

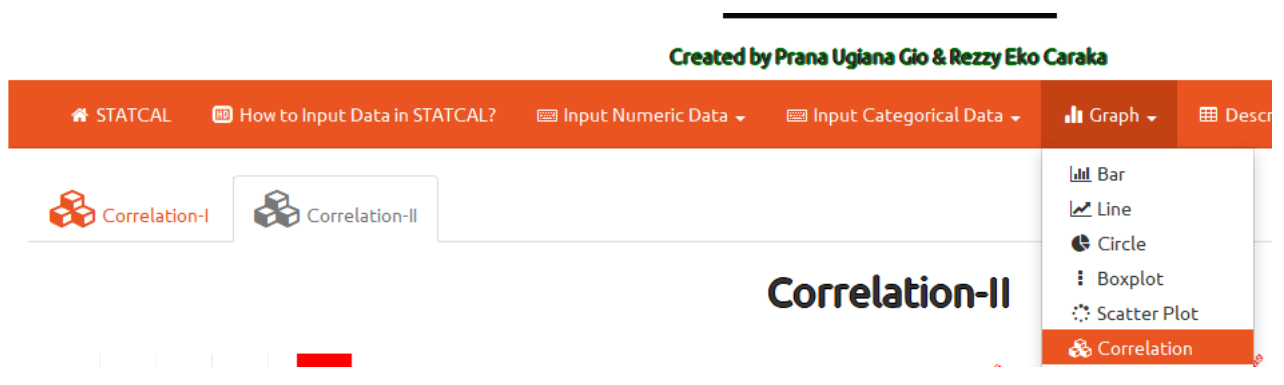

\section{Gambar 1.8 Menu Correlation-II}

Lakukan pemilihan variabel seperti pada Gambar 1.9.

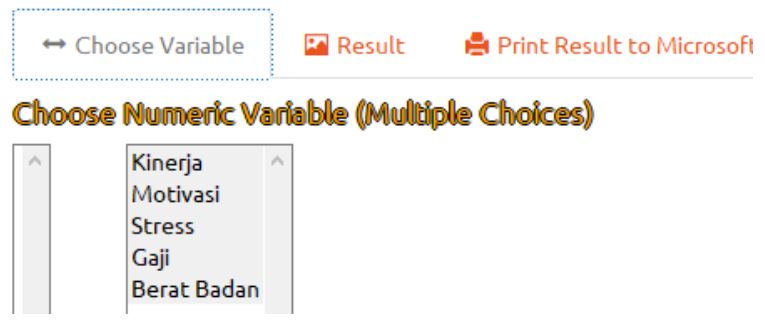

Gambar 1.9 Pemilihan Variabel 
Hasil dari grafik dapat dilihat pada bagian Result (Gambar 1.10).
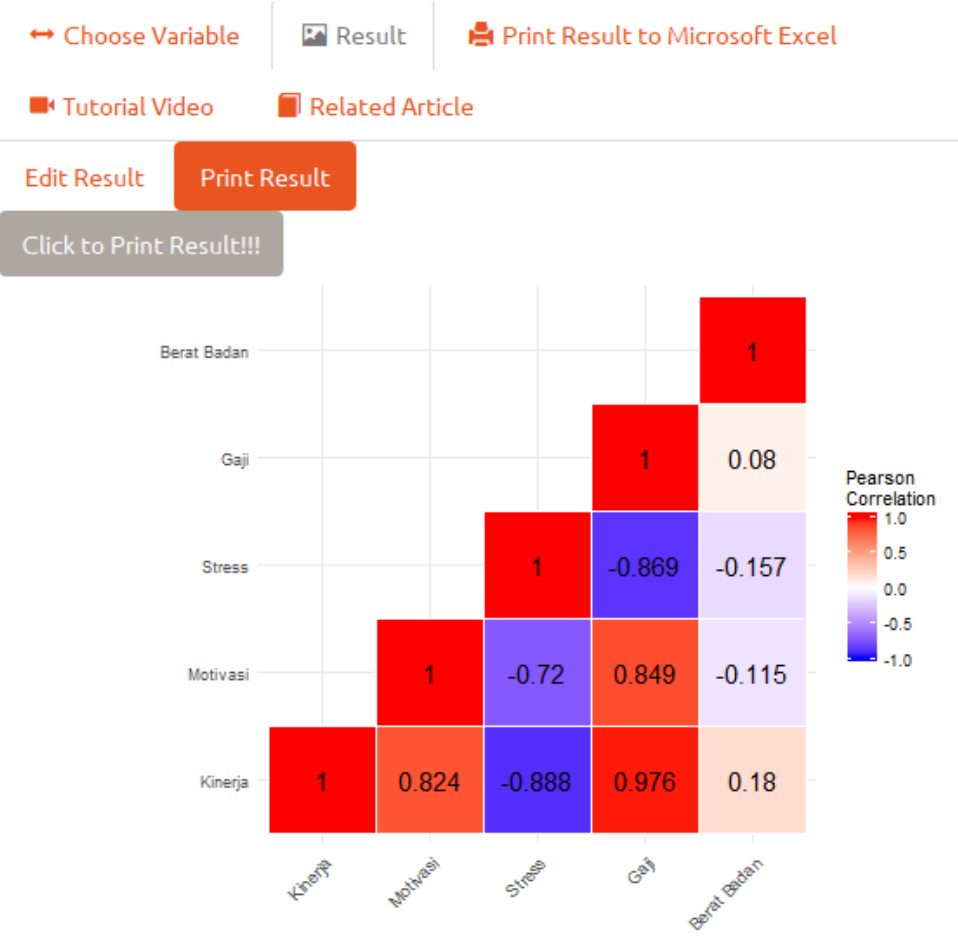

Input:

First: Numeric Voriable (Multiple Choices)

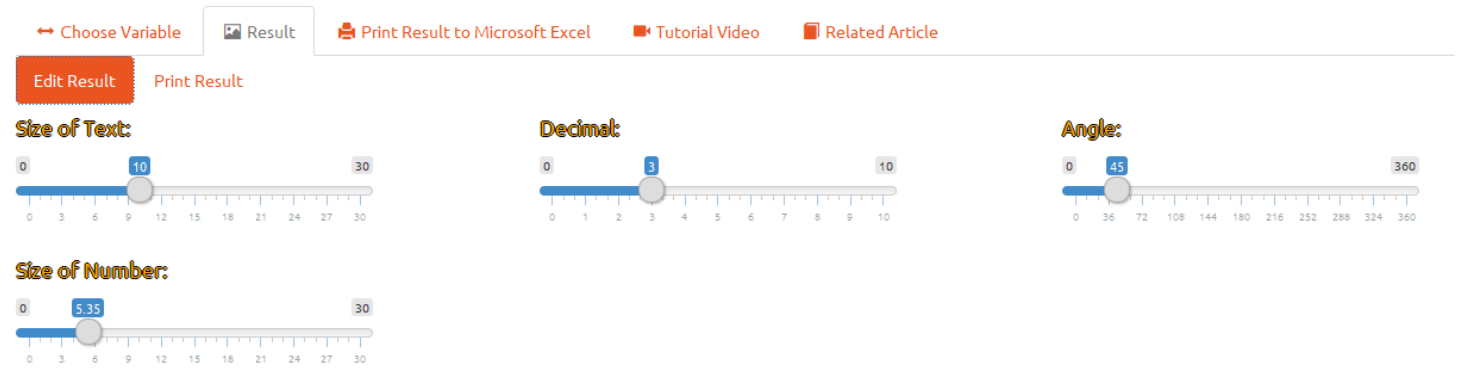

\section{Gambar 1.10 Result}




\section{Mengolah Data dengan} Program Aplikasi Statistika

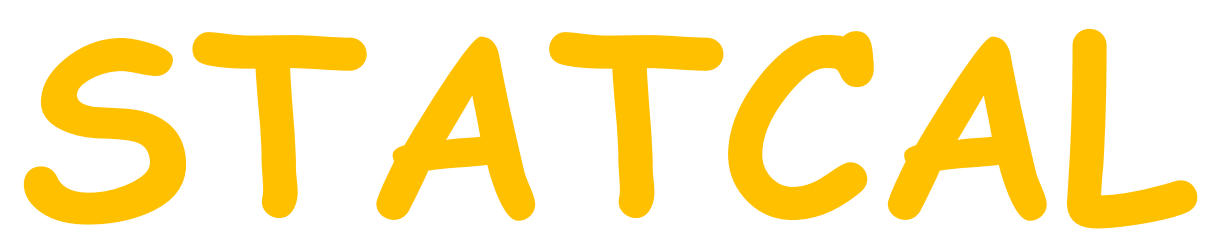

Membuat Grafik Sebaran Data dengan Menu

$$
\text { Scatter Plot-I }
$$

Oleh Prana Ugiana Gio

Founder \& CEO STATCAL

Created by Prana Ugiana Gio \& Rezzy Eko Caraka

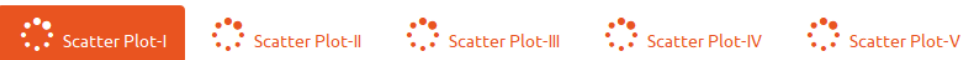

Scatter Plot-I
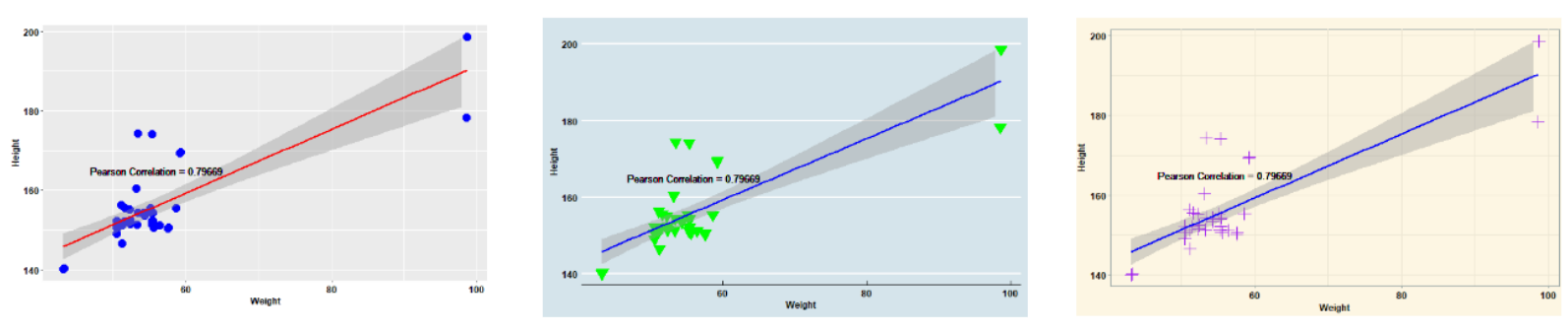
Andaikan diberikan data tinggi badan dan berat badan dari 10 siswa sebagai berikut (Tabel 1.1).

\section{Tabel 1.1 Data Tinggi dan Berat dari 10 Siswa}

\begin{tabular}{|c|c|c|}
\hline Nama & Tinggi Badan & Berat Badan \\
\hline A & 167.42 & 65.24 \\
\hline B & 159.62 & 58.51 \\
\hline C & 171.34 & 69.9 \\
\hline D & 162.12 & 60.63 \\
\hline E & 165.43 & 65.34 \\
\hline F & 166.23 & 67.53 \\
\hline G & 170.12 & 67.42 \\
\hline H & 151.53 & 50.41 \\
\hline I & 153.43 & 55.51 \\
\hline J & 163.23 & 63 \\
\hline
\end{tabular}

Berdasarkan data pada Tabel 1.1, disajikan grafik sebaran data antara tinggi badan dan berat badan, seperti pada Gambar 1.1.

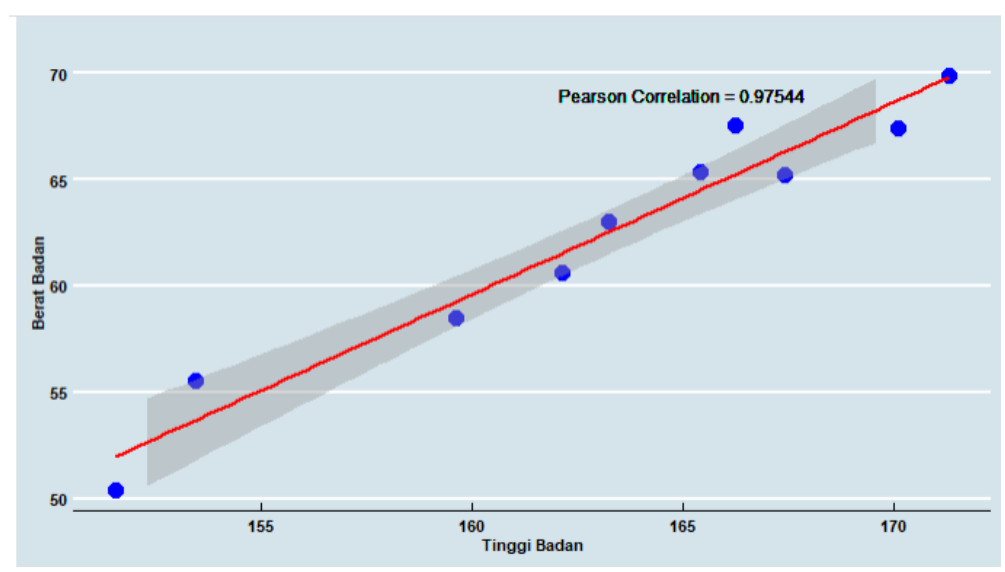

\section{Gambar 1.1 Grafik Sebaran Data antara Tinggi dan Berat}

Berdasarkan grafik sebaran data pada Gambar 1.1, terlihat bahwa sebaran data cenderung menyebar dari kiri bawah, menuju kanan atas. Dengan kata lain, semakin meningkat tinggi 
badan, terdapat kecenderungan, berat badan juga ikut meningkat. Diketahui juga bahwa nilai korelasi Pearson sebesar 0,97544. Untuk membuat grafik sebaran seperti pada Gambar 1.1, input data pada Tabel 1.1 ke dalam STATCAL, seperti pada Gambar 1.2.

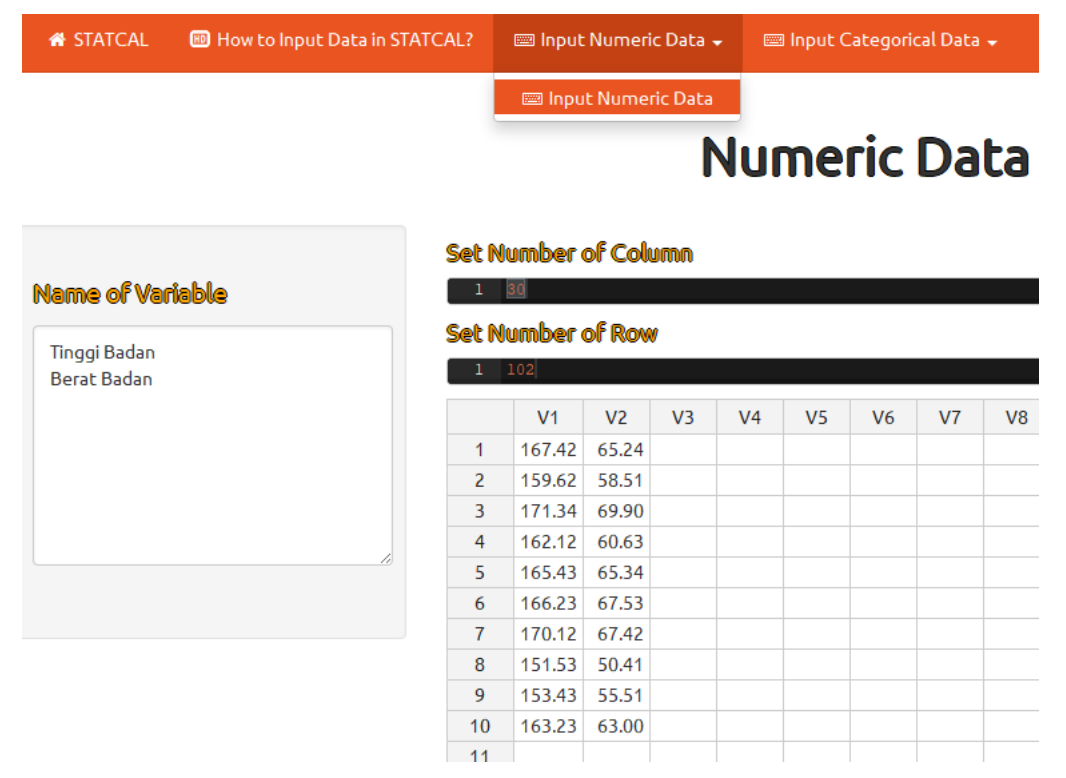

Gambar 1.2 Input Data Numerik

Selanjutnya pilih Graph => Scatter Plot (Gambar 1.3).

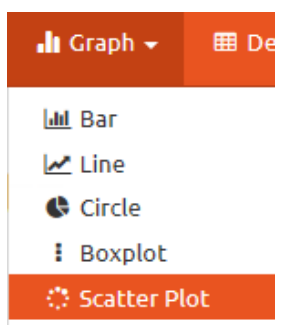

Gambar 1.3 Menu Scatter Plot 
Pilih menu Scatter Plot-I (Gambar 1.4).

Created by Prana Ugiana Gio \& Rezzy Eko Caraka
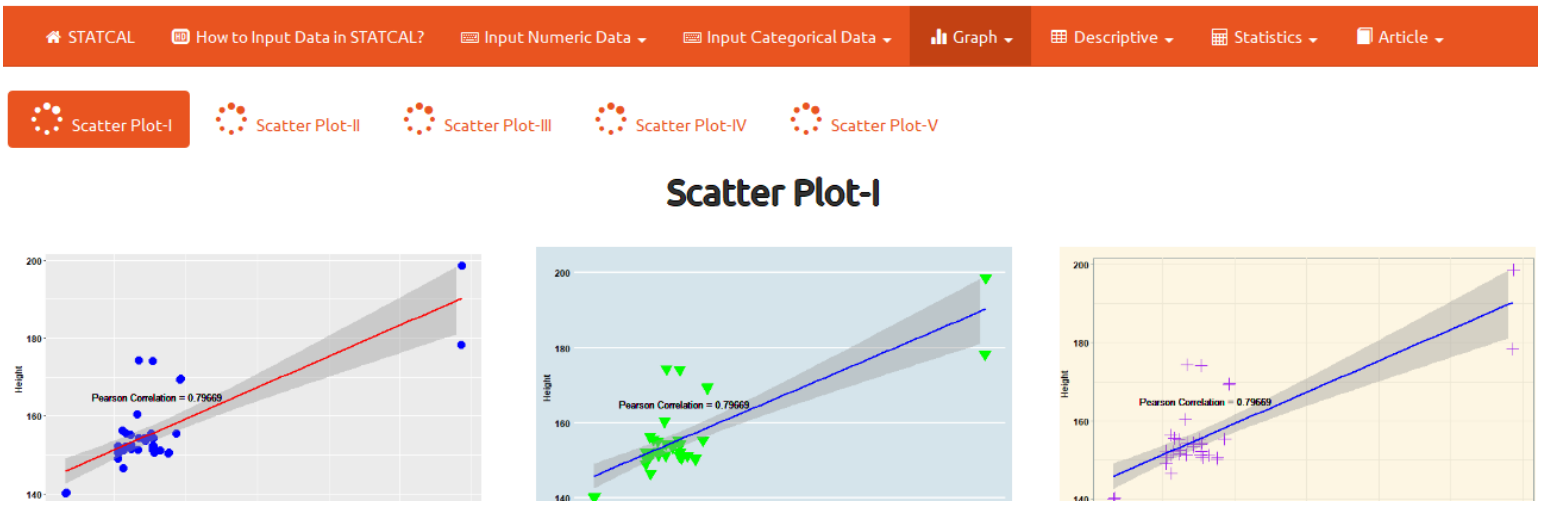

Gambar 1.4 Menu Scatter Plot-I

Perhatikan Gambar 1.5.

$\Rightarrow$ Pindahkan variabel tinggi badan ke kotak sebelah kanan pada bagian Choose Numeric Variable (Single Choice) (X-Axis).

$\Rightarrow$ Pindahkan variabel berat badan ke kotak sebelah kanan pada bagian Choose Numeric Variable (Single Choice) (Y-Axis).

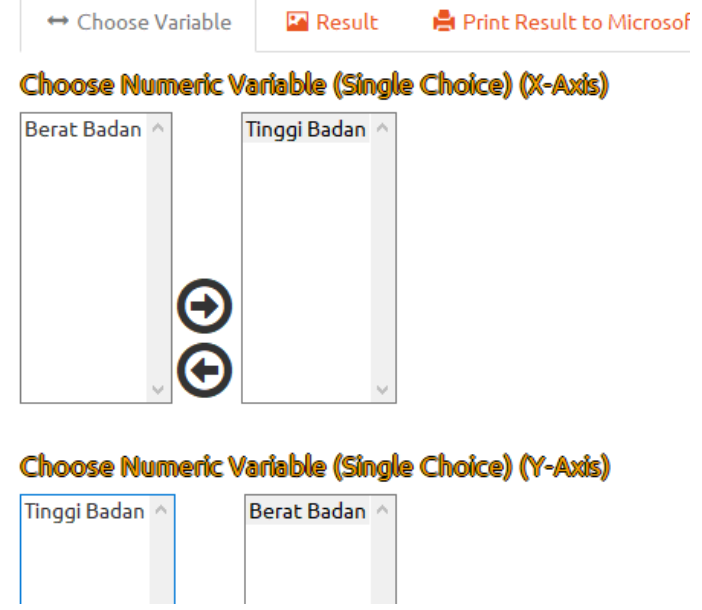

Gambar 1.5 Pemilihan Variabel 
Hasil dari grafik sebaran data dapat dilihat pada bagian Result (Gambar 1.6).

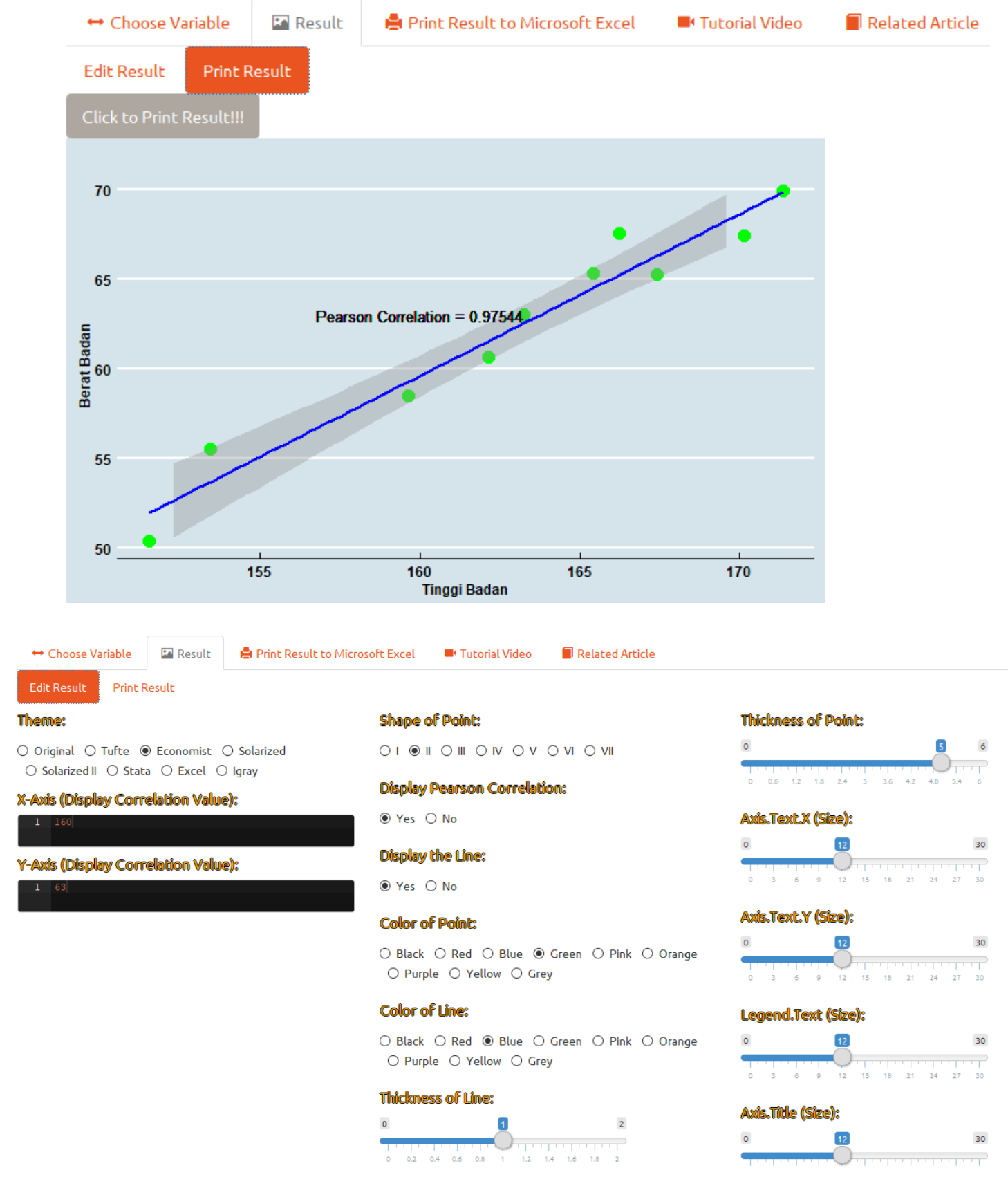

Gambar 1.6 Result 


\section{Mengolah Data dengan} Program Aplikasi Statistika
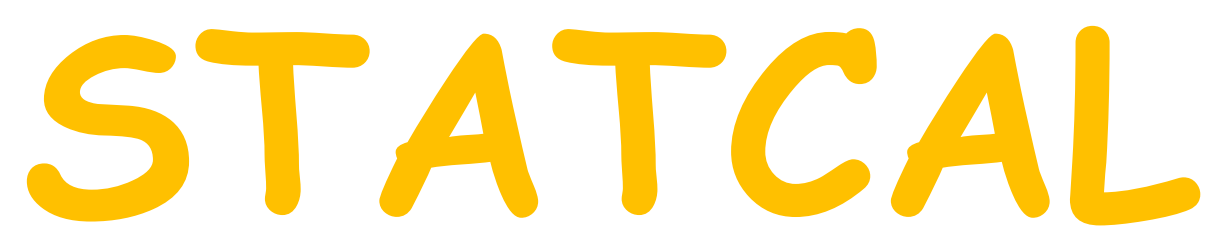

Membuat Grafik Sebaran Data dengan Menu

$$
\text { Scatter Plot-II }
$$

Oleh Prana Ugiana Gio

Founder \& CEO STATCAL

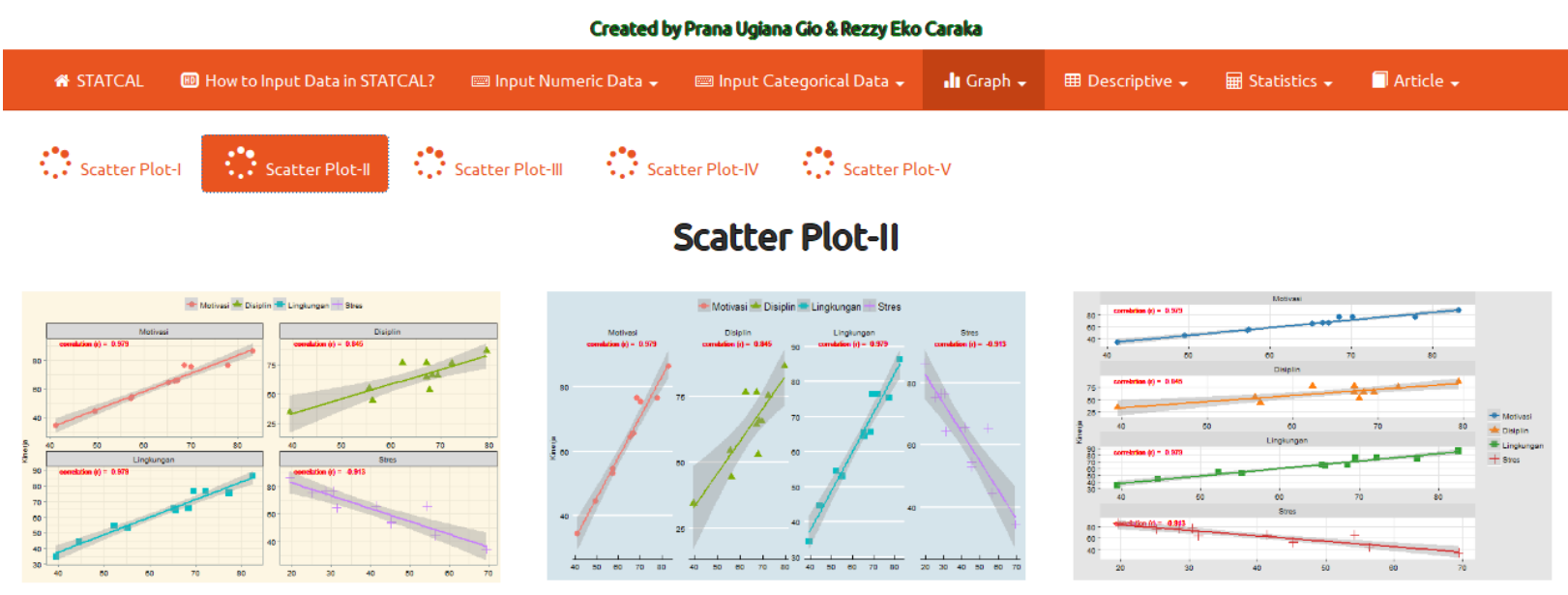


Misalkan diberikan data mengenai pengeluaran per-bulan, pendapatan per-bulan dan jumlah anak berdasarkan 10 keluarga (Tabel 1.1).

Tabel 1.1 Data Pengeluaran, Pendapatan dan Jumlah Anak dari 10 Keluarga (Data Fiktif)

\begin{tabular}{|c|c|c|c|}
\hline Responden & $\begin{array}{c}\text { Pengeluaran } \\
\text { (dalam jutaan) }\end{array}$ & $\begin{array}{c}\text { Pendapatan } \\
\text { (dalam jutaan) }\end{array}$ & Jumlah Anak \\
\hline 1 & 3.5 & 8.6 & 3 \\
\hline 2 & 4.2 & 6.5 & 3 \\
\hline 3 & 3.5 & 7.3 & 2 \\
\hline 4 & 2.7 & 6.4 & 2 \\
\hline 5 & 7.5 & 12.6 & 7 \\
\hline 6 & 2.5 & 5.3 & 1 \\
\hline 7 & 4.1 & 8.3 & 5 \\
\hline 8 & 3.6 & 7.4 & 2 \\
\hline 9 & 2.5 & 5.7 & 1 \\
\hline 10 & 4.1 & 7.4 & 4 \\
\hline
\end{tabular}

Berdasarkan data pada Tabel 1.1, disajikan grafik sebaran data sebagai berikut (Gambar 1.1).

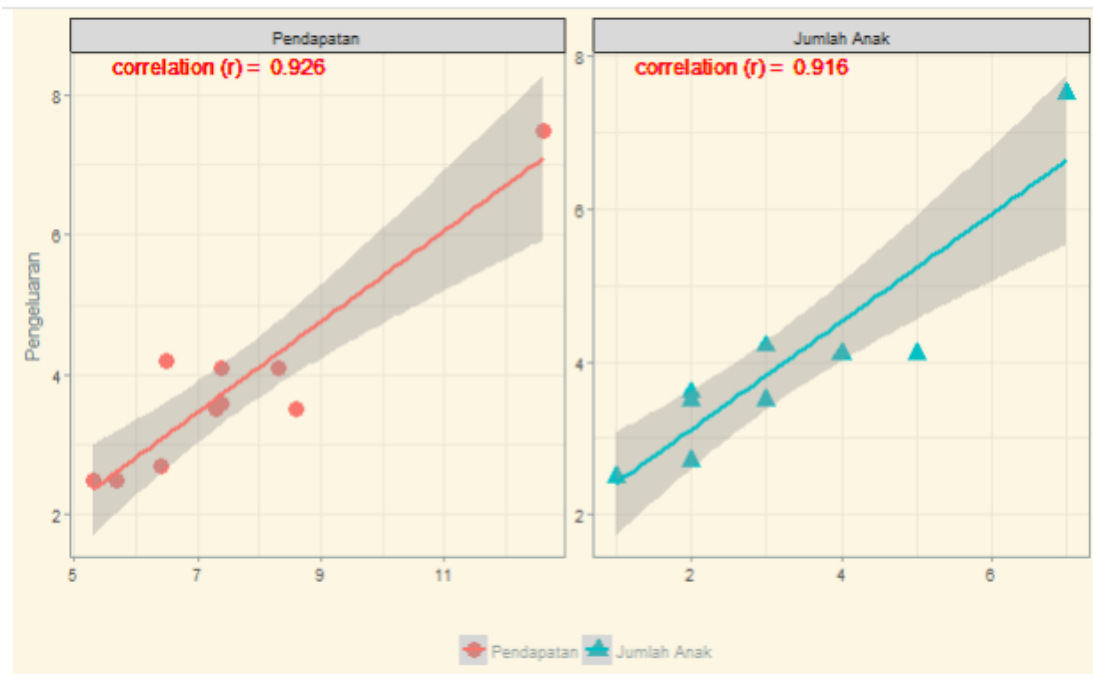

Gambar 1.1 Grafik Sebaran Data 
Perhatikan bahwa Gambar 1.1 merupakan grafik sebaran data antara pendapatan dan pengeluaran (warna merah), serta antara jumlah anak dan pengeluaran (warna hijau). Terlihat bahwa sebaran data antara pendapatan dan pengeluaran menyebar dari kiri bawah, menuju kanan atas. Dengan kata lain, pendapatan yang semakin meningkat, cenderung, pengeluaran juga meningkat. Begitu juga dengan jumlah anak. Jumlah anak yang semakin banyak, cenderung, pengeluaran meningkat.

Untuk membuat grafik sebaran seperti pada Gambar 1.1, input data pada Tabel 1.1 ke dalam STATCAL, seperti pada Gambar 1.2.

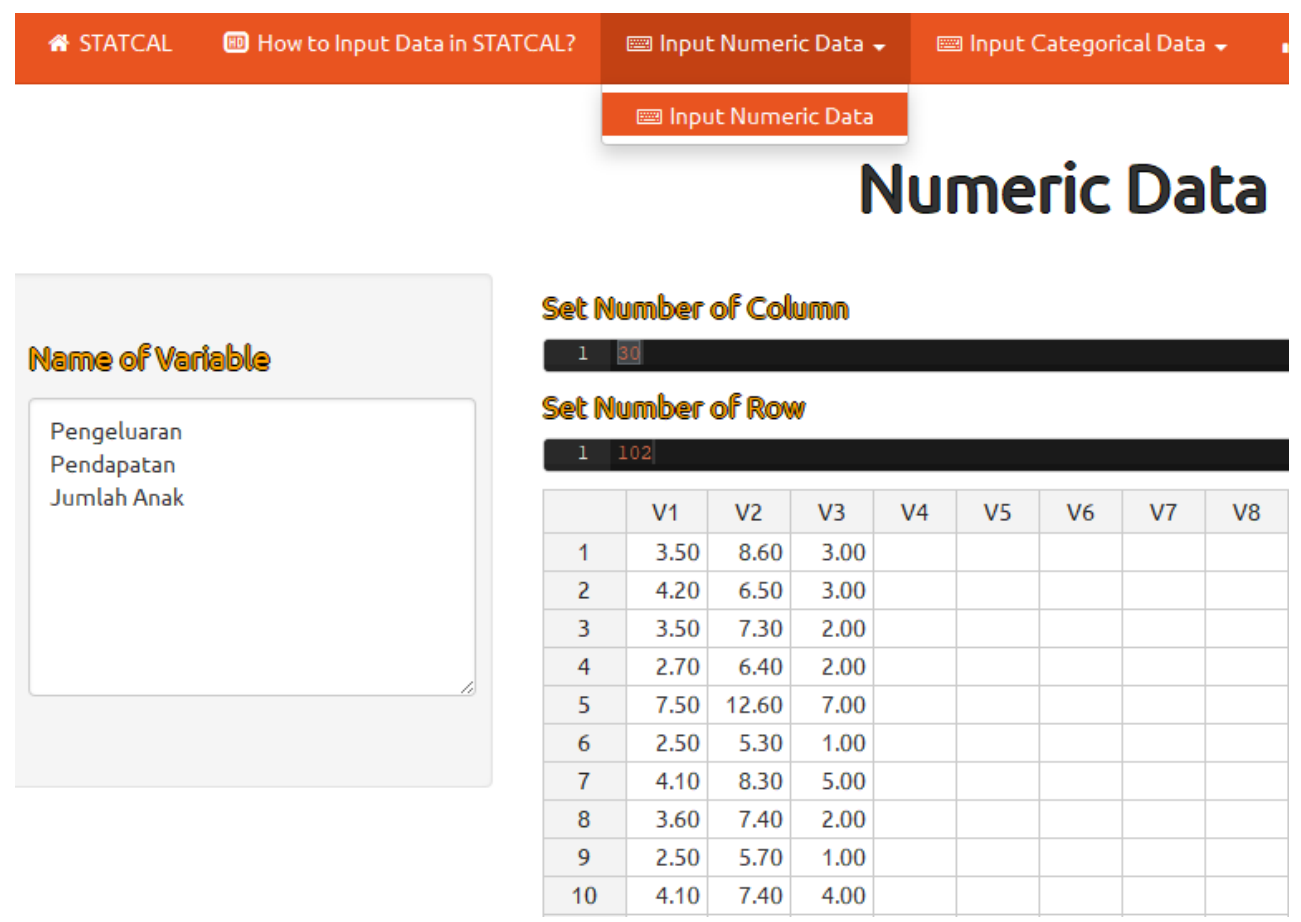

\section{Gambar 1.2 Input Data Numerik}

Selanjutnya pilih Graph => Scatter Plot (Gambar 1.3). 


\section{dl Graph - 四 D \\ Wlll Bar \\ L Line \\ Circle \\ ! Boxplot \\ Scatter Plot}

\section{Gambar 1.3 Menu Scatter Plot}

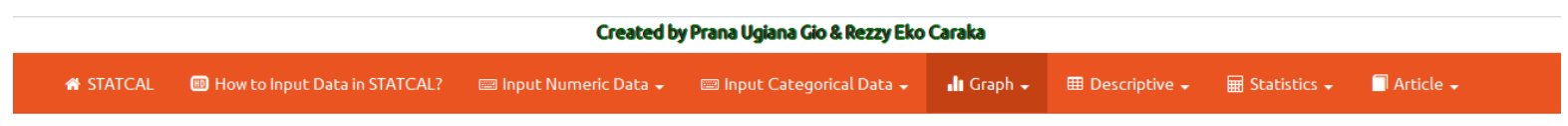

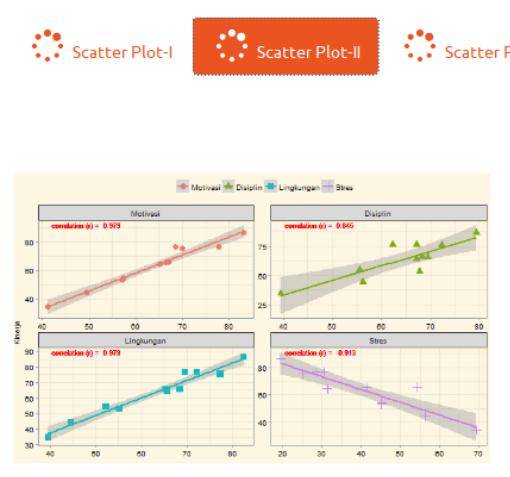

$\because \because$ scatter Plot-IV $\quad \because \because 9$ scatter Plot-V

\section{Scatter Plot-II}
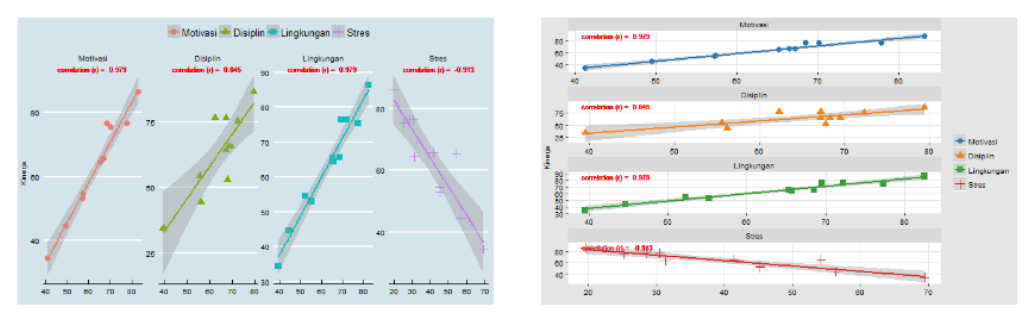

Gambar 1.4 Menu Scatter Plot-II

Pada Gambar 1.5:

$\Rightarrow$ Pindahkan variabel pendapatan dan jumlah anak ke kotak sebelah kanan pada bagian Choose Numeric Variable (Multiple Choices) (X-Axis).

$\Rightarrow$ Pindahkan variabel pengeluaran ke kotak sebelah kanan pada bagian Choose Numeric Variable (Single Choice) (Y-Axis). 

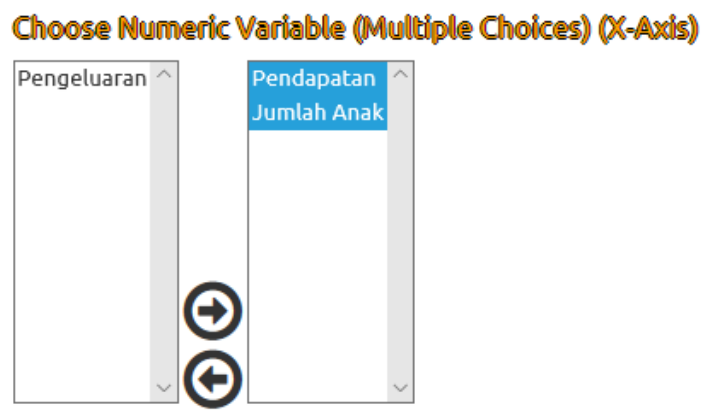

Choose Nunneric Variable (S5ingle Choice) (M-Axis)

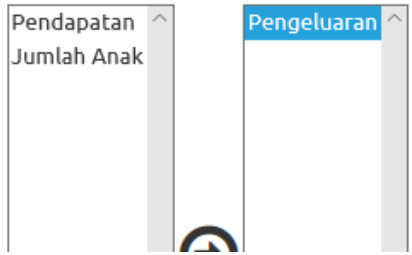

Gambar 1.5 Pemilihan Variabel

Hasil dari grafik sebaran data dapat dilihat pada bagian Result (Gambar 1.6).

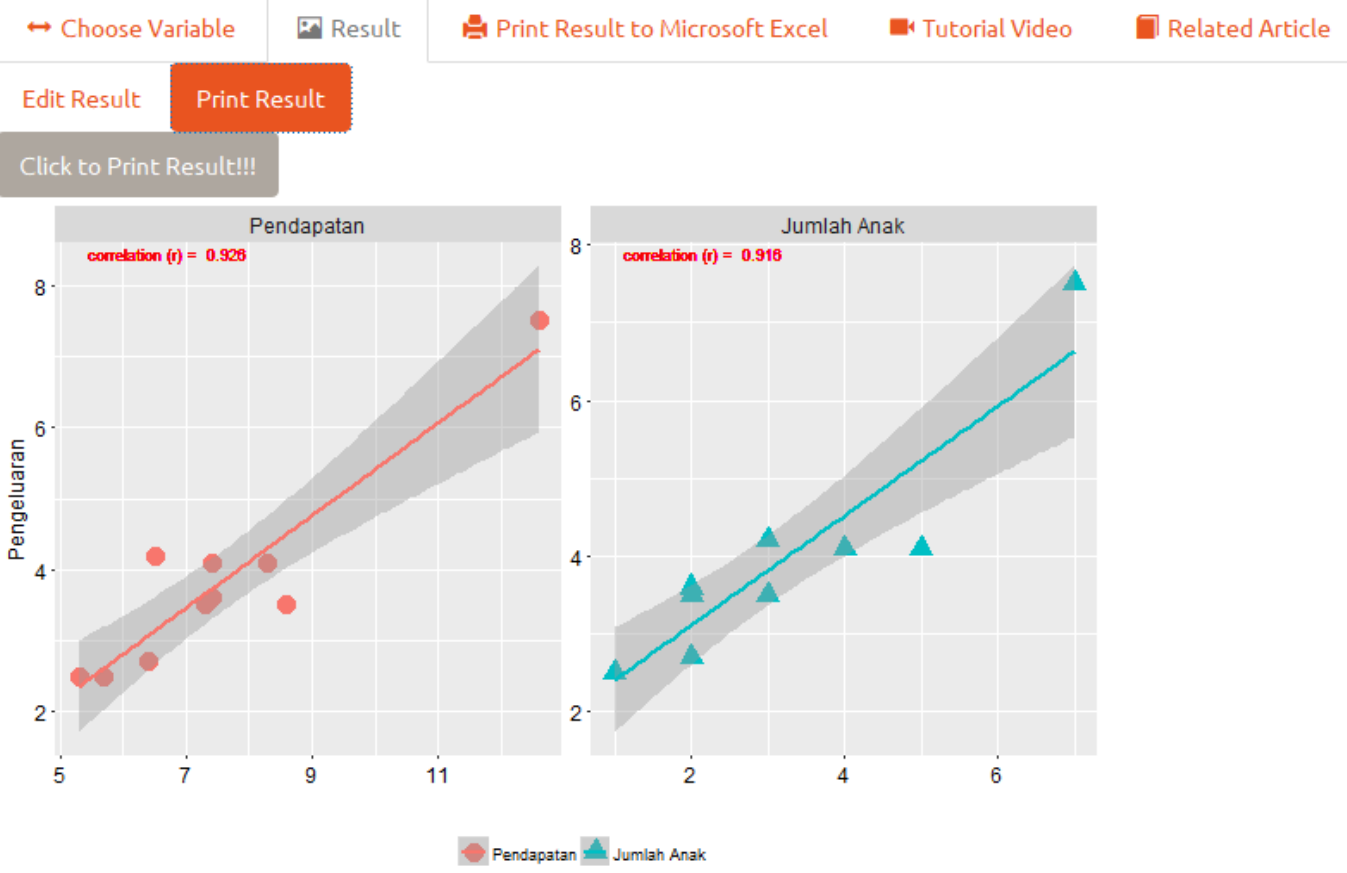

Gambar 1.6 Result 


\section{Mengolah Data dengan} Program Aplikasi

\section{Statistika}

Membuat Grafik Sebaran Data dengan Menu

$$
\text { Scatter Plot-III }
$$

\section{Oleh Prana Ugiana Gio}

Founder \& CEO STATCAL

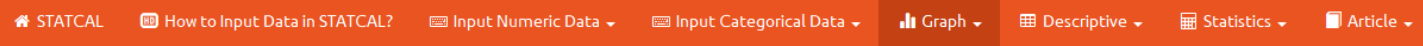
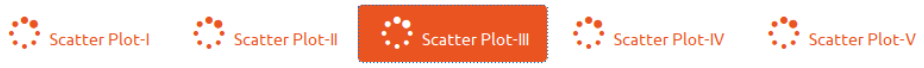

Scatter Plot-III

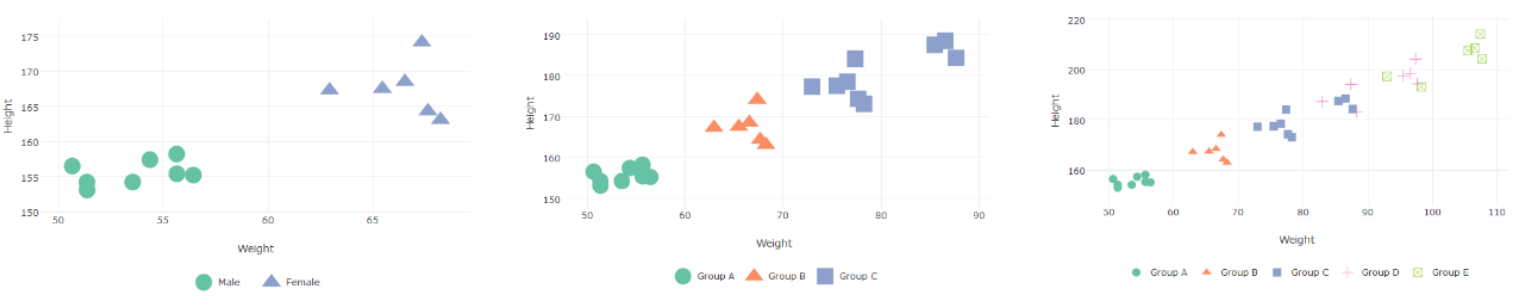


Misalkan diberikan data mengenai berat badan dan tinggi badan berdasarkan kelas A, kelas B dan kelas C (Tabel 1.1).

Tabel 1.1 Data Berat Badan dan Tinggi Badan dari 18 Siswa berdasarkan Kelas A, Kelas B dan Kelas C

\begin{tabular}{|c|c|c|c|}
\hline Nama & Kelas & Berat Badan $(\mathrm{Kg})$ & Tinggi Badan $(\mathrm{Cm})$ \\
\hline Andi & 1 & 56.23 & 156.42 \\
\hline Ani & 1 & 56.32 & 150.43 \\
\hline Suci & 1 & 56.43 & 155.43 \\
\hline Widya & 1 & 54.32 & 154.23 \\
\hline Sari & 1 & 55.43 & 152.46 \\
\hline Putri & 1 & 55.52 & 164.34 \\
\hline Intan & 2 & 55.52 & 162.31 \\
\hline Ugi & 2 & 54.26 & 160.74 \\
\hline Egi & 2 & 55.18 & 163.17 \\
\hline Wawan & 2 & 53.91 & 161.35 \\
\hline Sakti & 2 & 55.84 & 163.15 \\
\hline Cici & 2 & 55.15 & 180.43 \\
\hline Didi & 3 & 67.53 & 163.31 \\
\hline Wiwid & 3 & 66.24 & 163.35 \\
\hline Vivi & 3 & 64.64 & 167.31 \\
\hline Amar & 3 & 67.42 & 163.64 \\
\hline Odi & 3 & 68.51 & 167.52 \\
\hline Oman & 3 & 66.25 & 166.41 \\
\hline & & & \\
\hline
\end{tabular}

\begin{tabular}{|c|c|}
\hline Value & Label untuk Kelas \\
\hline 1 & Kelas A \\
\hline 2 & Kelas B \\
\hline 3 & Kelas C \\
\hline
\end{tabular}

Berdasarkan data pada Tabel 1.1, diketahui Andi dari kelas A, memiliki berat badan 56,23 $\mathrm{kg}$ dan tinggi badan 156,42 cm, Ugi dari kelas B, memiliki berat badan 54,26 kg dan tinggi badan 160,74 cm, dan seterusnya. Berdasarkan data pada Tabel 1.1, disajikan grafik sebaran data seperti pada Gambar 1.1. 


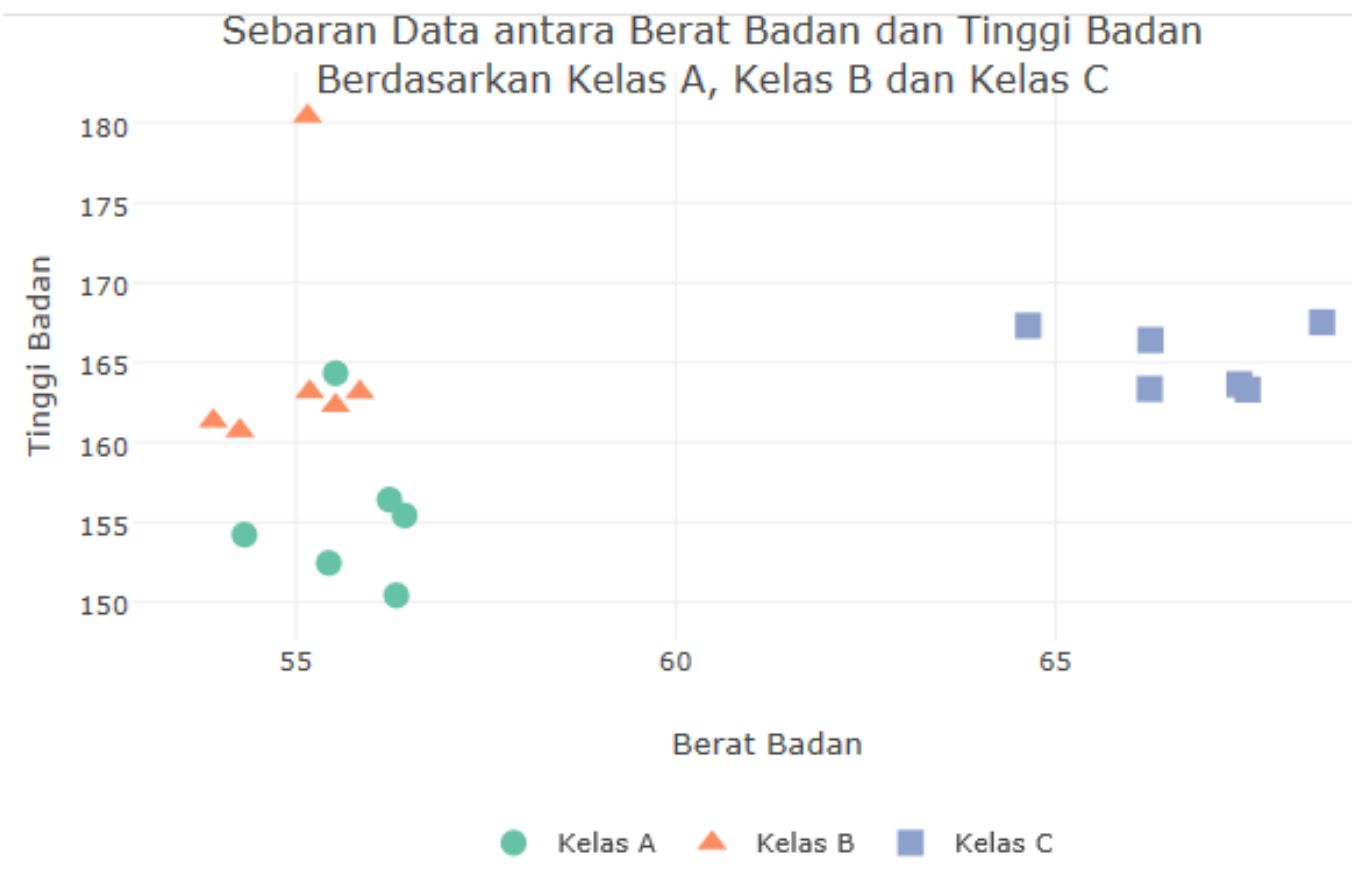

\section{Gambar 1.1 Sebaran Data Berat Badan dan Tinggi Badan Berdasarkan Kelas A, Kelas B dan Kelas C}

Berdasarkan sebaran data pada Gambar 1.1, terlihat bahwa mayoritas responden pada kelas C memiliki berat badan yang lebih tinggi, dibandingkan responden pada kelas A dan kelas B. Mayoritas responden pada kelas $\mathrm{C}$ juga memiliki tinggi badan yang lebih tinggi, dibandingkan kelas A. Pada kelas B, terdapat satu responden yang tinggi badannya di atas 180. Untuk membuat grafik sebaran seperti pada Gambar 1.1, input data pada Tabel 1.1 ke dalam STATCAL, seperti pada Gambar 1.2 dan Gambar 1.3. 


\section{Numeric Data}

\begin{tabular}{|c|c|c|c|c|c|c|c|c|c|c|}
\hline \multirow{4}{*}{$\begin{array}{l}\text { Nanne of Variable } \\
\text { Berat Badan } \\
\text { Tinggi Badan }\end{array}$} & \multicolumn{10}{|c|}{ Set' Nuñoer of Coluñon } \\
\hline & \multirow{2}{*}{\multicolumn{10}{|c|}{ Selt Number of Row }} \\
\hline & & & & & & & & & & \\
\hline & \multicolumn{10}{|c|}{$\begin{array}{ll}1 & 102\end{array}$} \\
\hline & & V1 & V2 & V3 & V4 & V5 & V6 & v7 & V8 & $\mathrm{V} !$ \\
\hline & 1 & 56.23 & 156.42 & & & & & & & \\
\hline & 2 & 56.32 & 150.43 & & & & & & & \\
\hline & 3 & 56.43 & 155.43 & & & & & & & \\
\hline & 4 & 54.32 & 154.23 & & & & & & & \\
\hline & 5 & 55.43 & 152.46 & & & & & & & \\
\hline & 6 & 55.52 & 164.34 & & & & & & & \\
\hline & 7 & 55.52 & 162.31 & & & & & & & \\
\hline & 8 & 54.26 & 160.74 & & & & & & & \\
\hline & 9 & 55.18 & 163.17 & & & & & & & \\
\hline & 10 & 53.91 & 161.35 & & & & & & & \\
\hline & 11 & 55.84 & 163.15 & & & & & & & \\
\hline & 12 & 55.15 & 180.43 & & & & & & & \\
\hline & 13 & 67.53 & 163.31 & & & & & & & \\
\hline & 14 & 66.24 & 163.35 & & & & & & & \\
\hline
\end{tabular}

Gambar 1.2 Input Data Numerik

Categorical Data
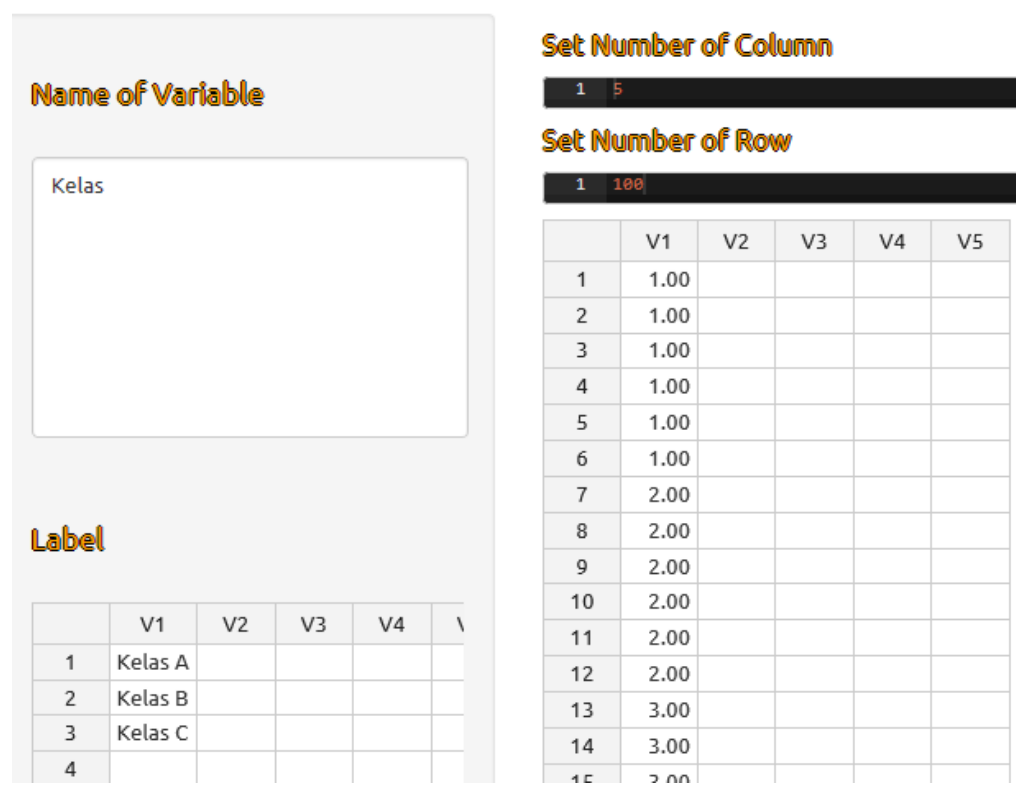

Gambar 1.3 Input Data Kategori 
Selanjutnya pilih Graph => Scatter Plot (Gambar 1.4).

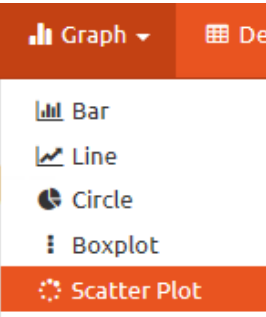

Gambar 1.4 Menu Scatter Plot

Perhatikan Gambar 1.5. Pilih menu Scatter Plot-III.

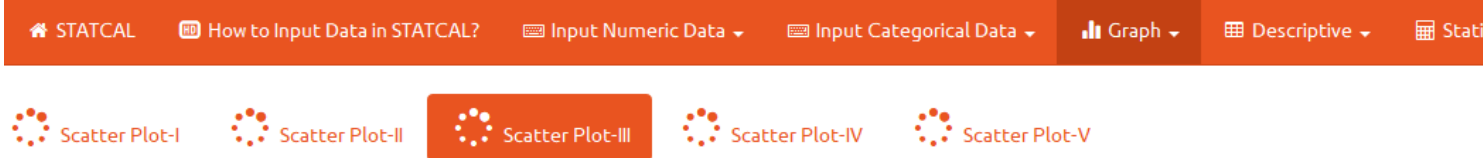

Scatter Plot-III

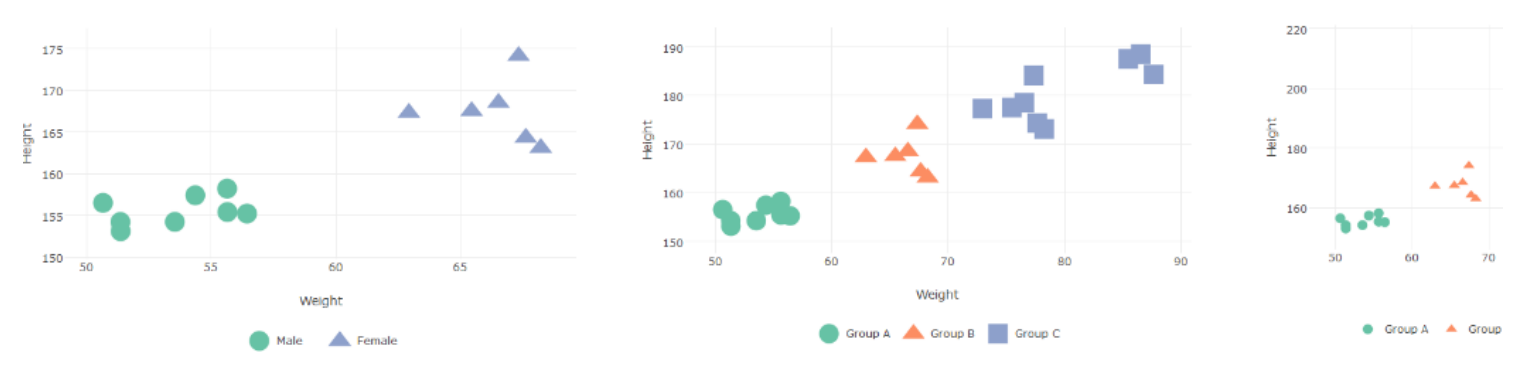

Gambar 1.5 Menu Scatter Plot-III

Pada Gambar 1.6:

$\Rightarrow$ Pindahkan variabel kelas ke kotak sebelah kanan, pada bagian Choose Categorical Variable (Single Choice).

$\Rightarrow$ Pindahkan variabel berat badan ke kotak sebelah kanan pada bagian Choose Numeric Variable (Single Choice) (X-Axis). 
$\Rightarrow$ Pindahkan variabel tinggi badan ke kotak sebelah kanan pada bagian Choose Numeric Variable (Single Choice) (Y-Axis).
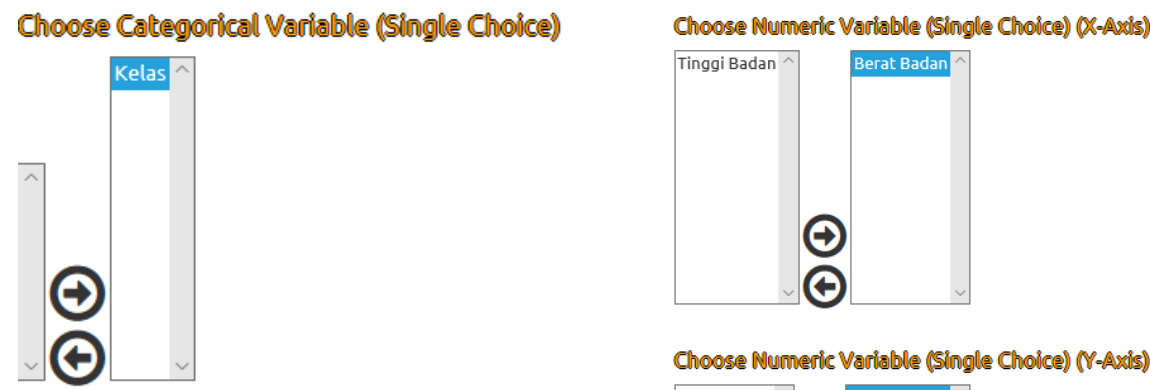

Choose Nunieric Variable (ISingle Choice) (X-Axis) Tinggi Badan ^ Berat Badan
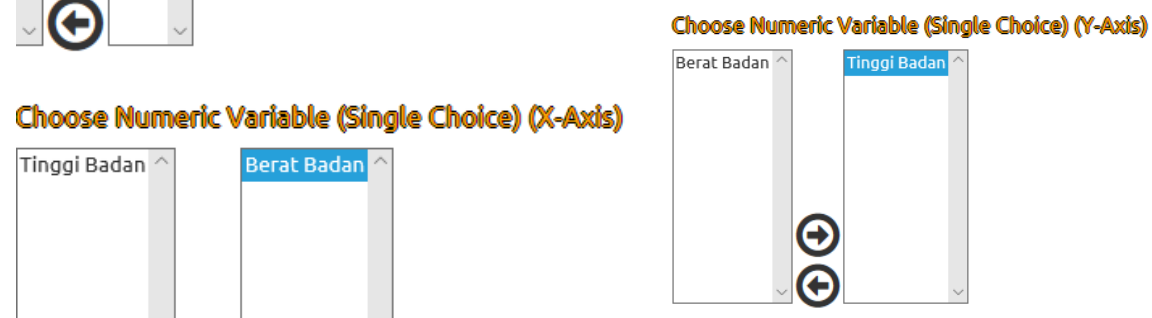

Gambar 1.6 Pemilihan Variabel

Hasil dari grafik sebaran data dapat dilihat pada bagian Result (Gambar 1.7).
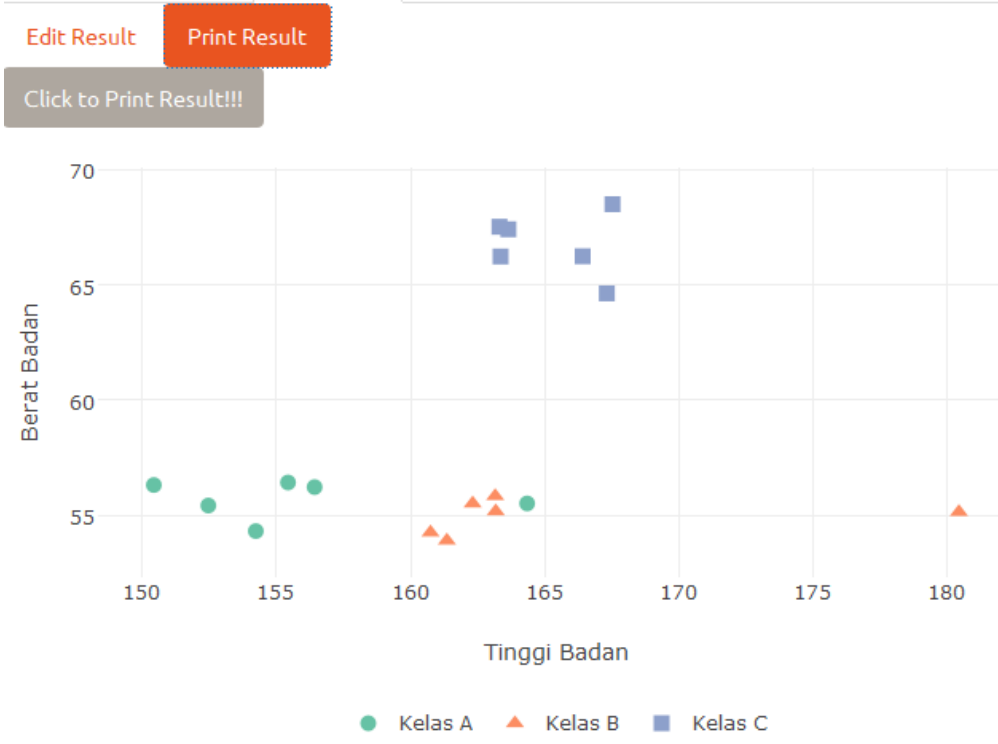

\section{Gambar 1.7 Result}




\section{Mengolah Data dengan} Program Aplikasi Statistika
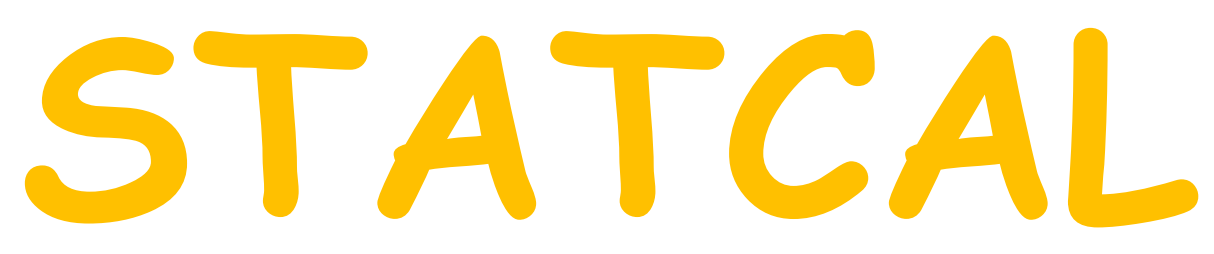

Membuat Grafik Sebaran Data dengan Menu

$$
\text { Scatter Plot-IV }
$$

Oleh Prana Ugiana Gio

Founder \& CEO STATCAL

Created by Prana Ugiana Gio \& Rezzy Eko Caraka

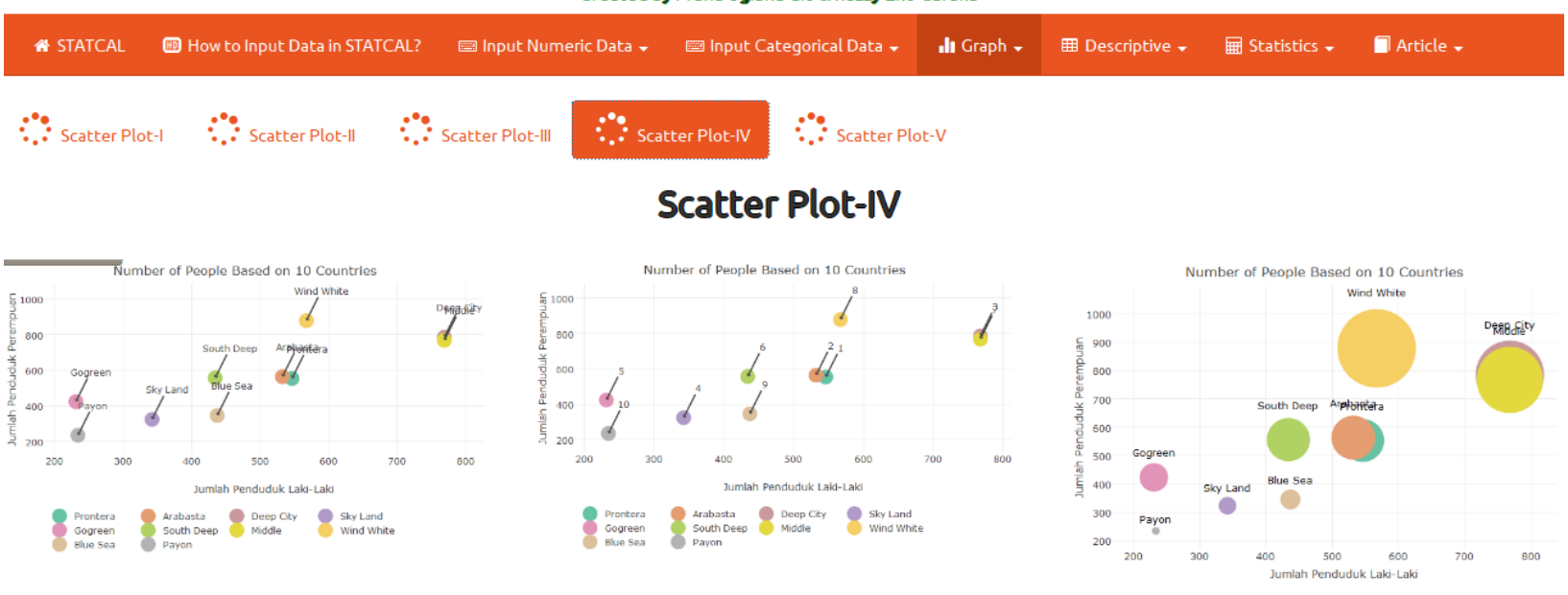


Misalkan diberikan data jumlah penduduk laki-laki dan perempuan berdasarkan 8 negara (Tabel $1.1)$.

\section{Tabel 1.1 Jumlah Penduduk Laki-Laki dan Perempuan berdasarkan 8 Negara (Data Fiktif)}

\begin{tabular}{|c|c|c|c|}
\hline Negara (Value) & Label & Jumlah Laki-Laki & Jumlah Perempuan \\
\hline 1 & Wakanda Jaya & 4523 & 4123 \\
\hline 2 & Prontera & 1235 & 2323 \\
\hline 3 & Payon & 5235 & 3352 \\
\hline 4 & Arabasta & 4523 & 2356 \\
\hline 5 & Api & 9875 & 9567 \\
\hline 6 & Wklandia & 4526 & 2634 \\
\hline 7 & Timur Barat & 5774 & 5223 \\
\hline 8 & Utara Selatan & 1345 & 1344 \\
\hline
\end{tabular}

Berdasarkan data pada Tabel 1.1, disajikan grafik sebaran data seperti pada Gambar 1.1 sampai Gambar 1.3.

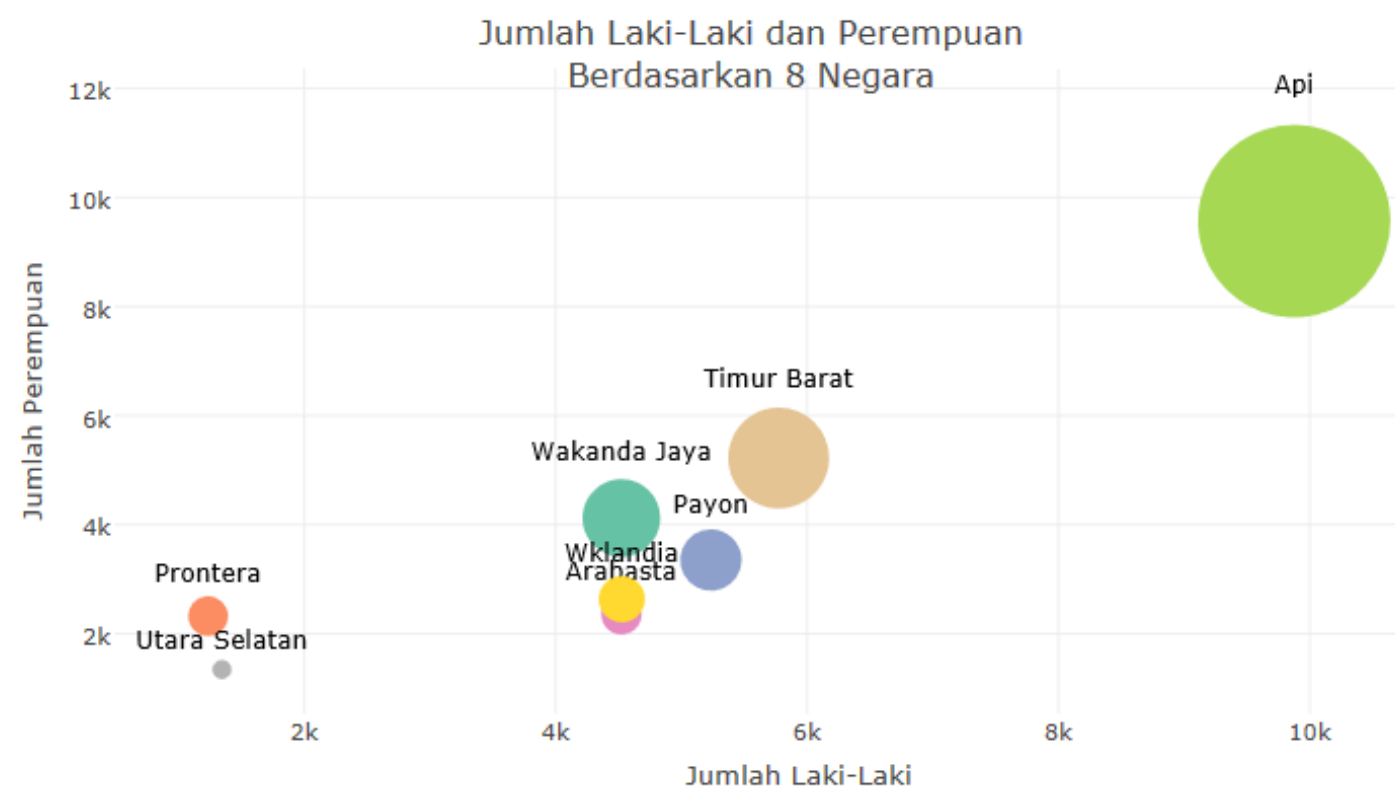

Gambar 1.1 Jumlah Penduduk Laki-Laki dan Perempuan Berdasarkan 8 Negara 


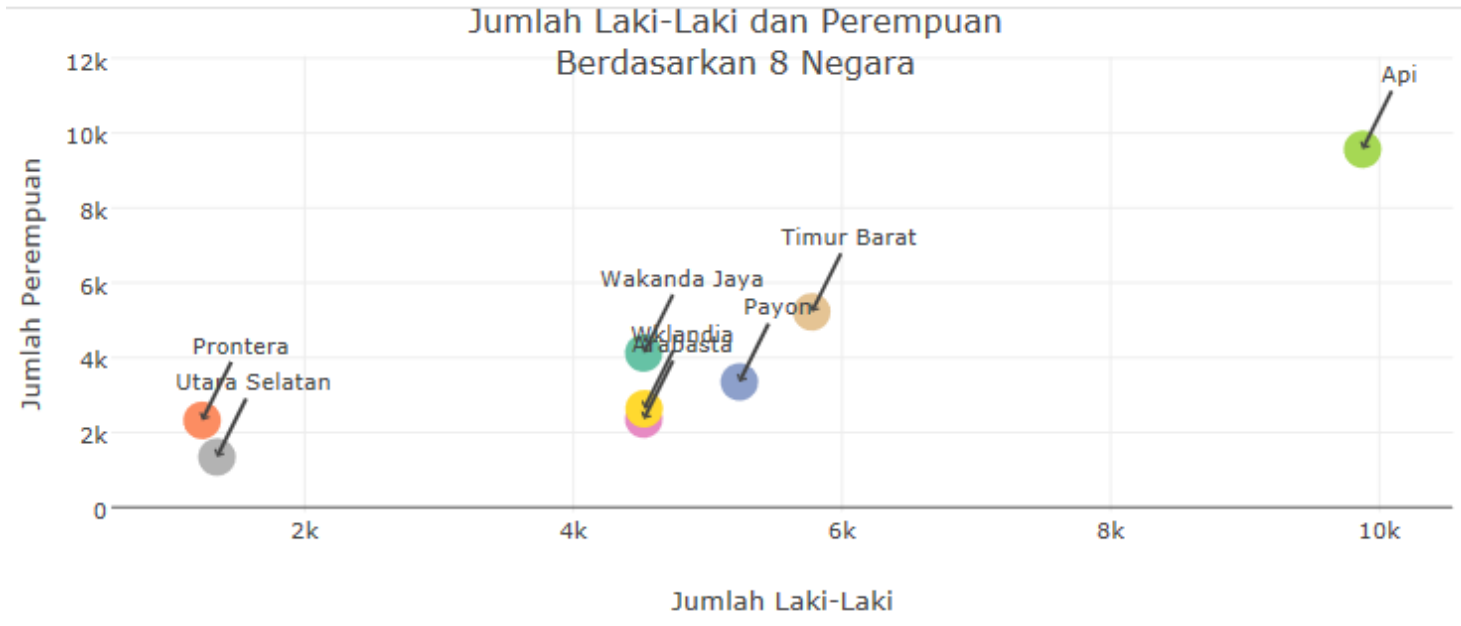

\section{Gambar 1.2 Jumlah Penduduk Laki-Laki dan Perempuan Berdasarkan 8 Negara}

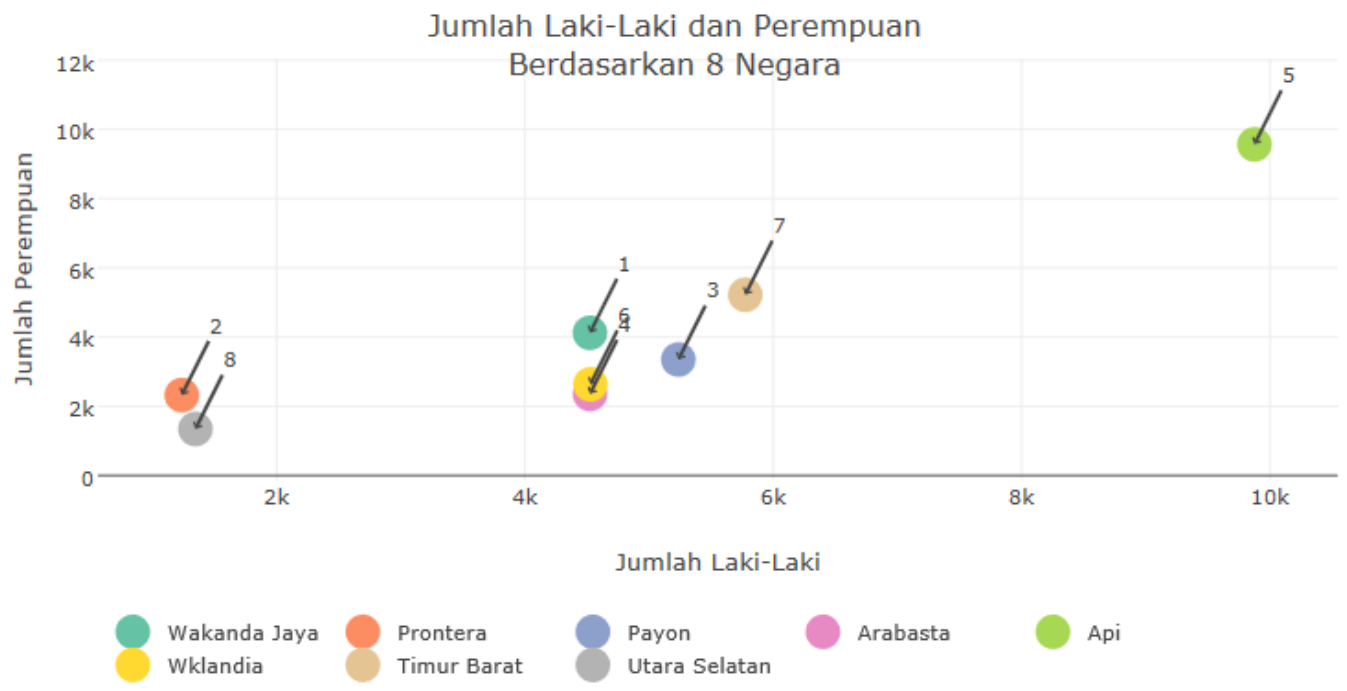

\section{Gambar 1.3 Jumlah Penduduk Laki-Laki dan Perempuan Berdasarkan 8 Negara}

Untuk membuat grafik sebaran seperti pada Gambar 1.1 sampai Gambar 1.3, input data pada

Tabel 1.1 ke dalam STATCAL, seperti pada Gambar 1.4 dan Gambar 1.5. 


\section{STATCAL 四 How to Input Data in STATCAL? 㻁 Input Numeric Data v 回 Input Categorical Data v}

\section{慖 Input Numeric Data}

Numeric Data

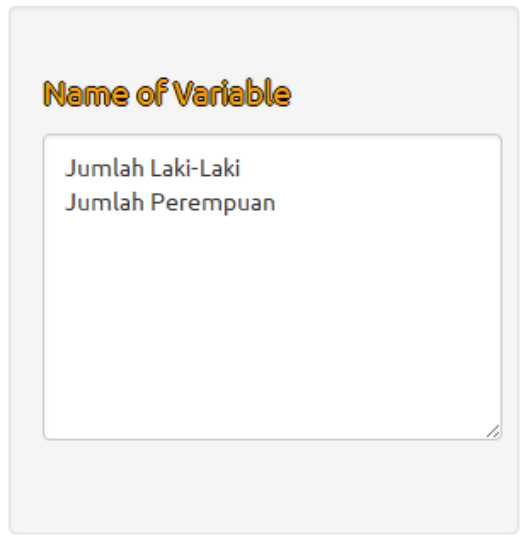

Set' Number of coluño

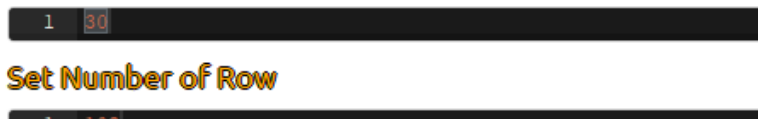

\begin{tabular}{|c|c|c|c|c|c|c|c|}
\hline \multicolumn{1}{|c|}{102} & V2 & V3 & V4 & V5 & V6 & V7 & I \\
\hline 1 & 4523.00 & 4123.00 & & & & & \\
\hline 2 & 1235.00 & 2323.00 & & & & & \\
\hline 3 & 5235.00 & 3352.00 & & & & & \\
\hline 4 & 4523.00 & 2356.00 & & & & & \\
\hline 5 & 9875.00 & 9567.00 & & & & & \\
\hline 6 & 4526.00 & 2634.00 & & & & & \\
\hline 7 & 5774.00 & 5223.00 & & & & & \\
\hline 8 & 1345.00 & 1344.00 & & & & & \\
\hline$n$ & & & & & & \\
\hline
\end{tabular}

Gambar 1.4 Input Data Numerik

\section{Categorical Data}

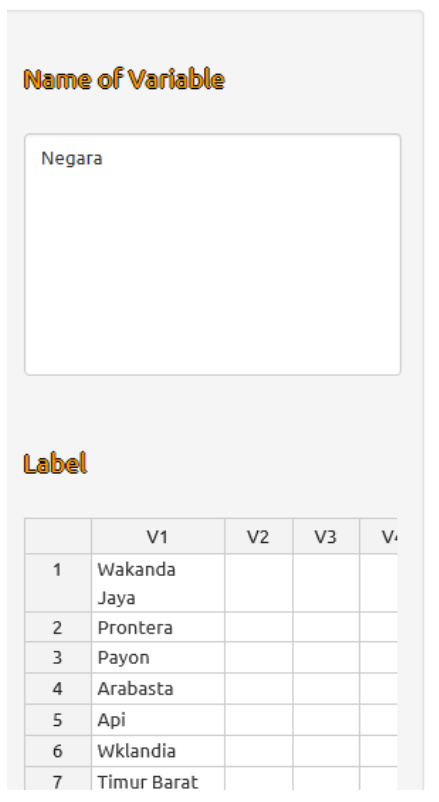

Set' Number of Colunon

\section{Sett Number of Row}
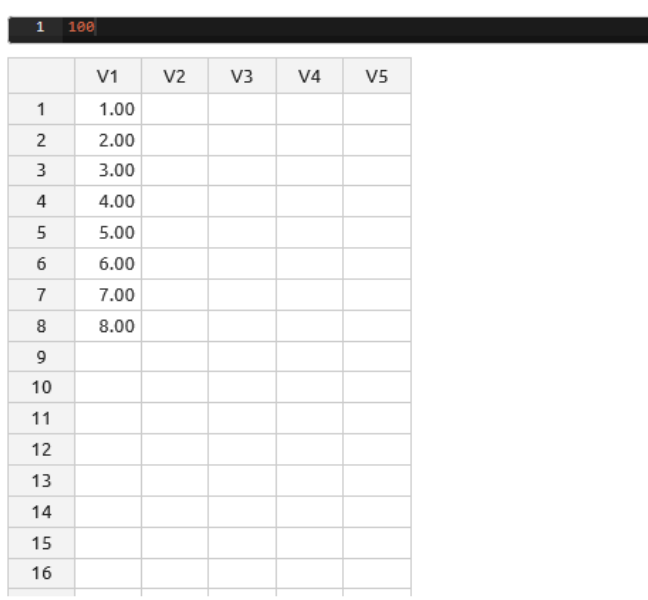

Gambar 1.5 Input Data Kategori

Selanjutnya pilih Graph => Scatter Plot (Gambar 1.6). 


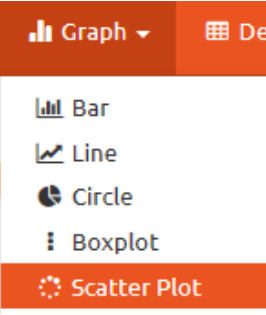

\section{Gambar 1.6 Menu Scatter Plot}

Perhatikan Gambar 1.7. Pilih menu Scatter Plot-IV.

Created by Prana Ugiana Gio \& Rezzy Eko Caraka

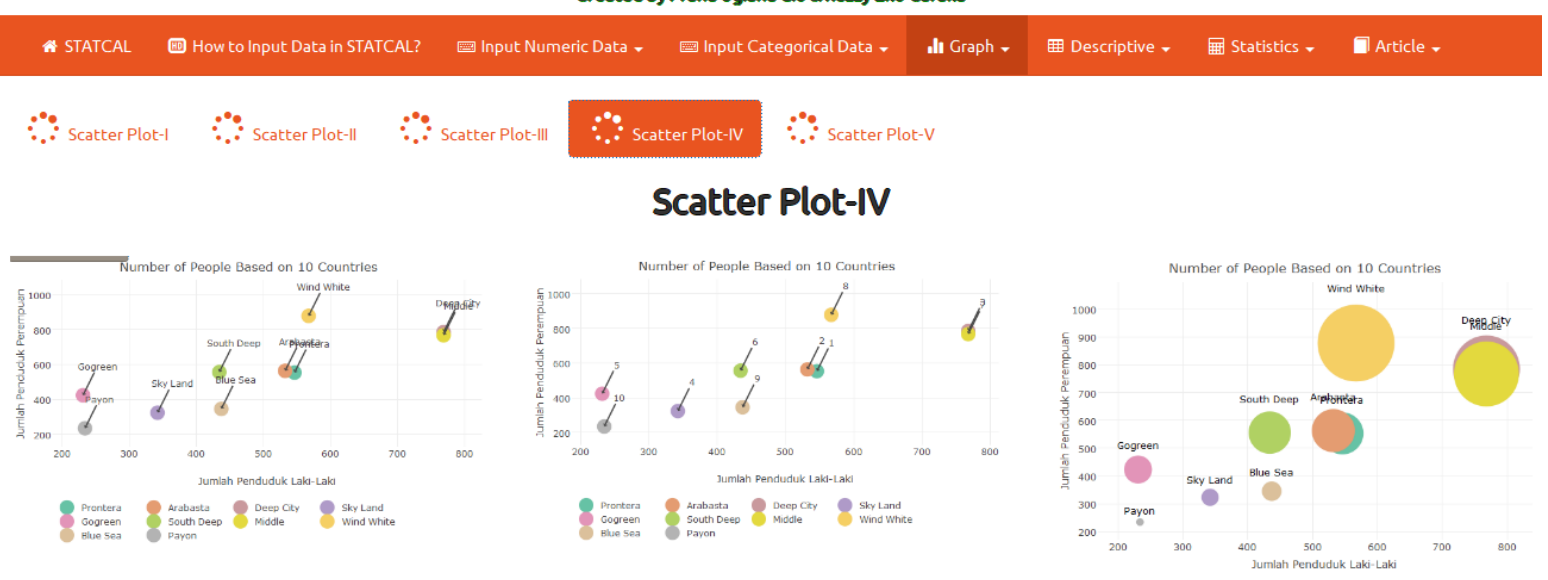

\section{Gambar 1.7 Menu Scatter Plot-IV}

Pada Gambar 1.8:

$\Rightarrow$ Pindahkan variabel kelas ke kotak sebelah kanan, pada bagian Choose Categorical Variable (Single Choice).

$\Rightarrow$ Pindahkan variabel berat badan ke kotak sebelah kanan pada bagian Choose Numeric Variable (Single Choice) (X-Axis).

$\Rightarrow$ Pindahkan variabel tinggi badan ke kotak sebelah kanan pada bagian Choose Numeric Variable (Single Choice) (Y-Axis). 
Choose Numeric Variable (SIlngle Choice) (XX-Axxis)

Choose Cattegorical Variable (Slingle Choice)
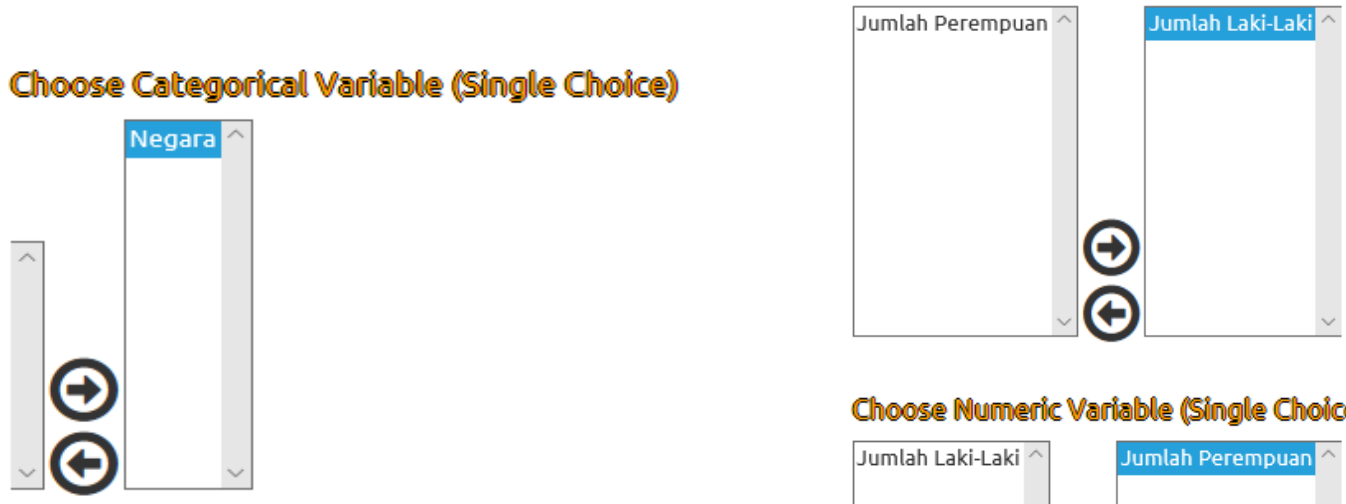

Choose Numeric Variable (SIlngle Choice) (MaAxis)

Choose Nunieric Variable (ISlingle Choice) (X-Axxis)
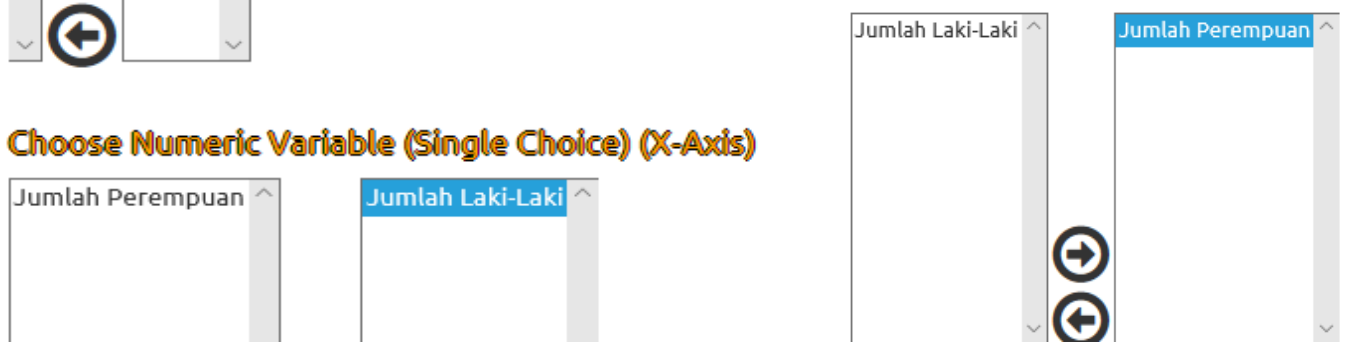

Gambar 1.8 Pemilihan Variabel

Hasil dari grafik sebaran data dapat dilihat pada bagian Result. 


\section{Mengolah Data dengan} Program Aplikasi Statistika

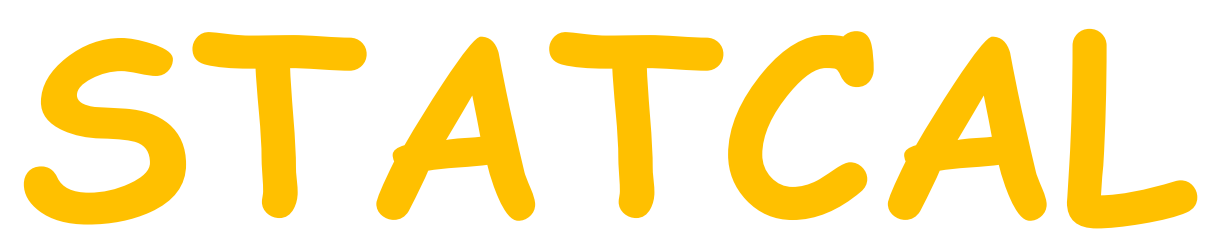

Membuat Grafik Sebaran Data dengan Menu

$$
\text { Scatter Plot-V }
$$

Oleh Prana Ugiana Gio

Founder \& CEO STATCAL

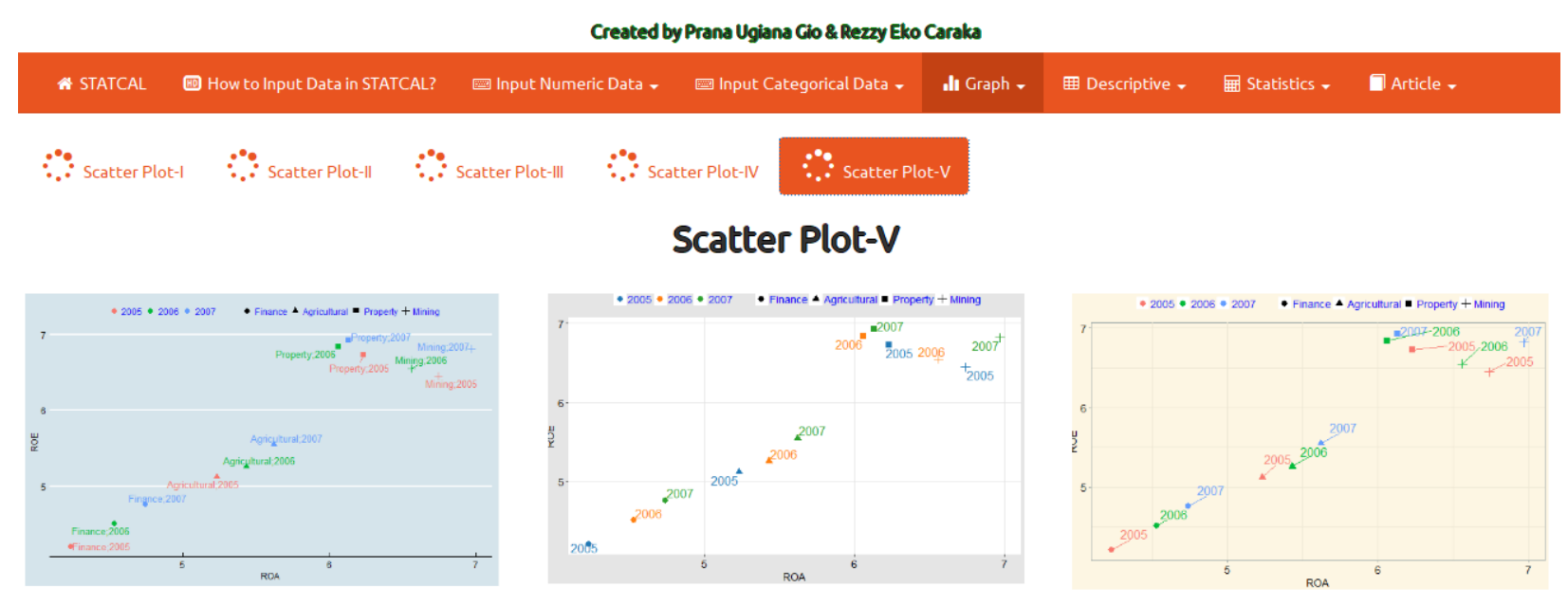


Misalkan diberikan data jumlah penduduk laki-laki dan perempuan berdasarkan 4 negara, dari tahun 2015-2017 (Tabel 1.1).

Tabel 1.1 Jumlah Penduduk Laki-Laki dan Perempuan berdasarkan 4 Negara, Tahun 2015-2017 (Data Fiktif)

\begin{tabular}{|c|c|c|c|}
\hline Negara & Tahun & Jumlah Laki-Laki & Jumlah Perempuan \\
\hline 1 & 1 & 146 & 164 \\
\hline 1 & 2 & 157 & 179 \\
\hline 1 & 3 & 173 & 200 \\
\hline 2 & 1 & 264 & 274 \\
\hline 2 & 2 & 278 & 321 \\
\hline 2 & 3 & 300 & 347 \\
\hline 3 & 1 & 756 & 843 \\
\hline 3 & 2 & 777 & 890 \\
\hline 3 & 3 & 800 & 1003 \\
\hline 4 & 1 & 545 & 675 \\
\hline 4 & 2 & 578 & 700 \\
\hline 4 & 3 & 600 & 853 \\
\hline
\end{tabular}

\begin{tabular}{|c|c|c|}
\hline Angka & Negara & Tahun \\
\hline 1 & Wakanda & 2015 \\
\hline 2 & Alberta & 2016 \\
\hline 3 & Prontera & 2017 \\
\hline 4 & Arabasta & \\
\hline
\end{tabular}

Berdasarkan data pada Tabel 1.1, disajikan grafik sebaran data seperti pada Gambar 1.1 dan Gambar 1.2. 


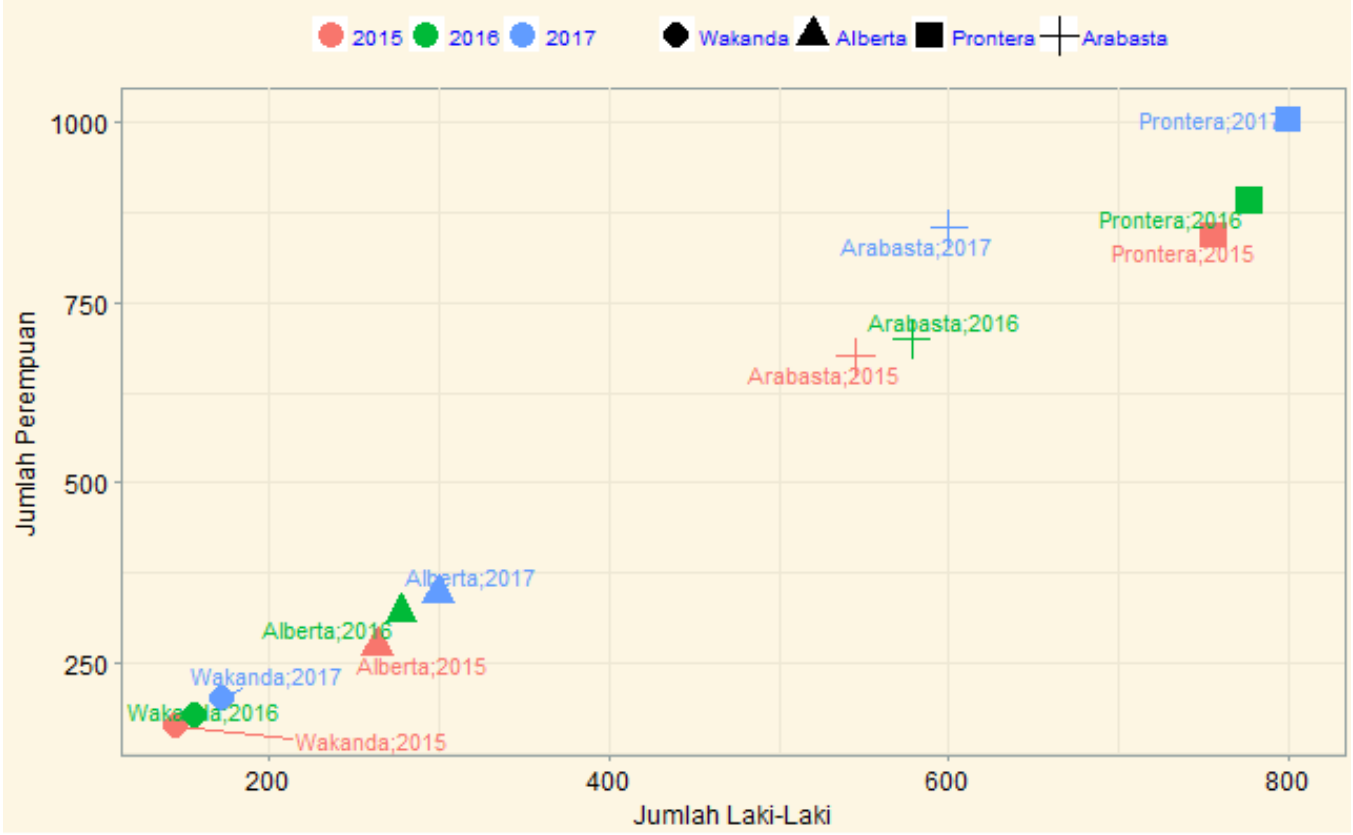

Gambar 1.1 Jumlah Penduduk Laki-Laki dan Perempuan Berdasarkan 4 Negara, Tahun 2015-2017

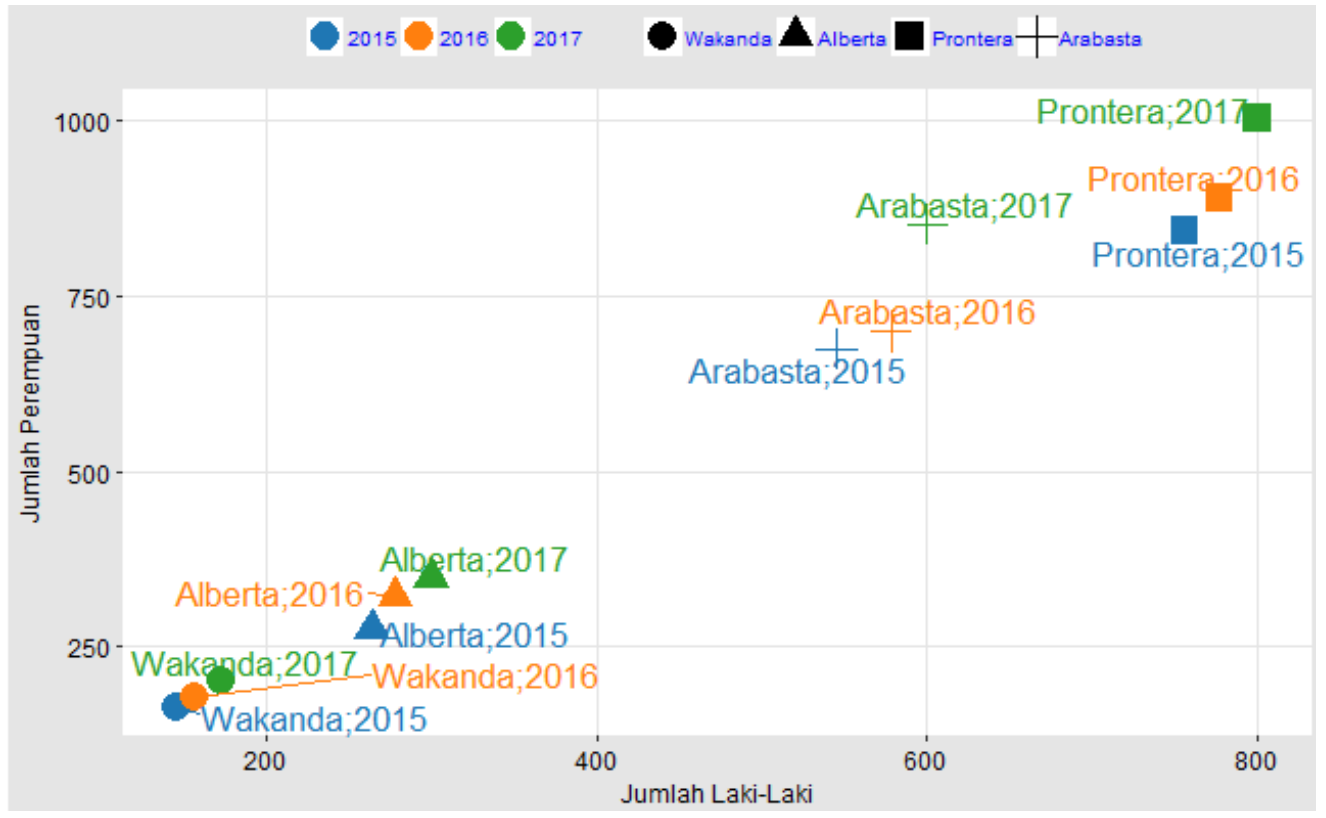

Gambar 1.2 Jumlah Penduduk Laki-Laki dan Perempuan Berdasarkan 4 Negara, Tahun 2015-2017 
Untuk membuat grafik sebaran seperti pada Gambar 1.1 dan Gambar 1.2, input data pada Tabel 1.1 ke dalam STATCAL, seperti pada Gambar 1.3 dan Gambar 1.4.

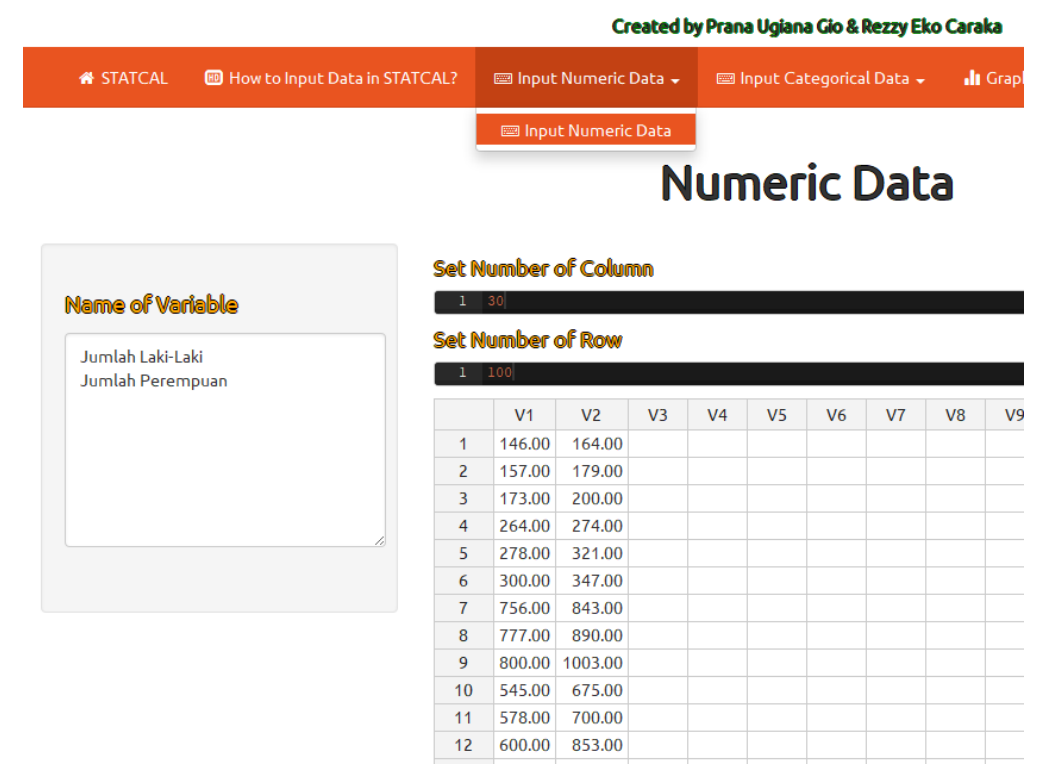

Gambar 1.3 Input Data Numerik

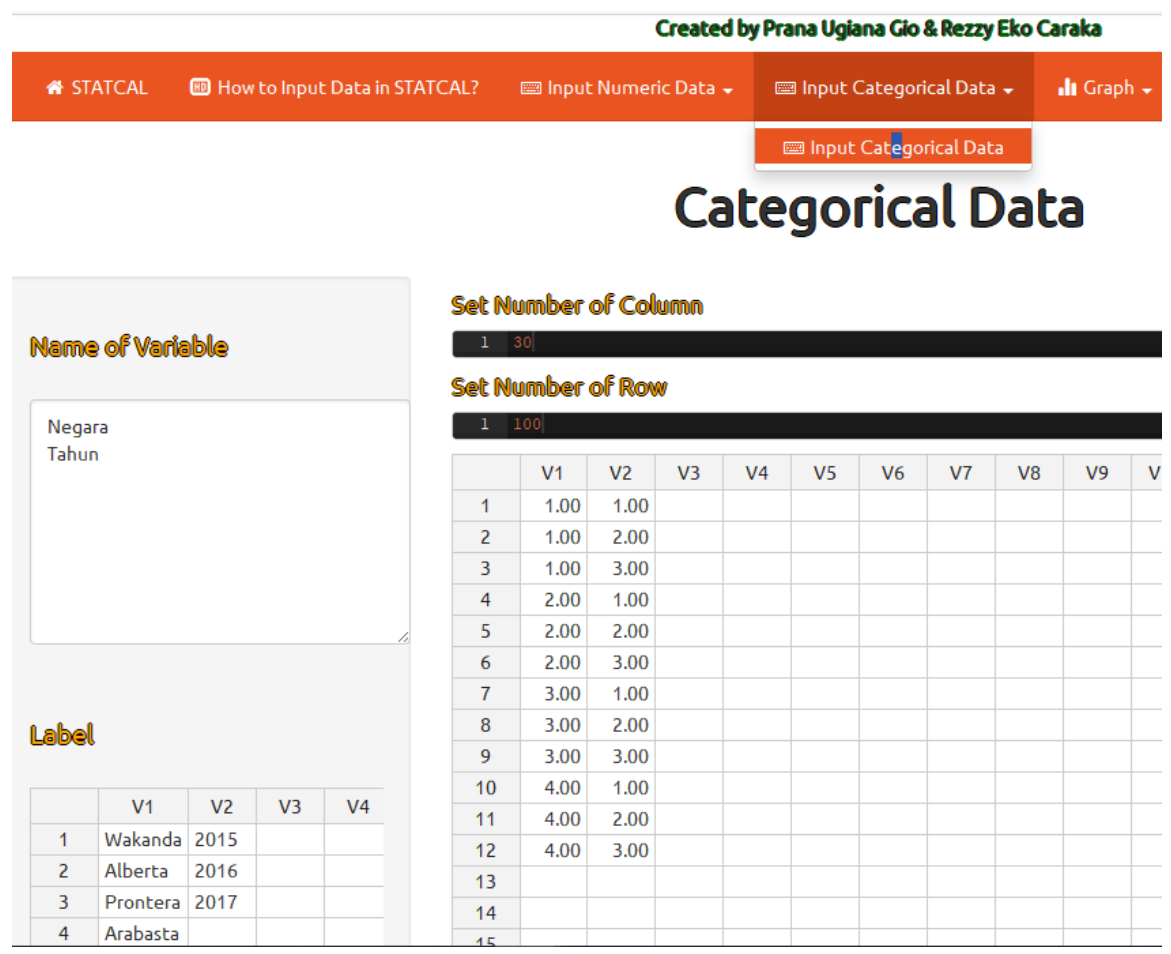

Gambar 1.4 Input Data Kategori 
Selanjutnya pilih Graph => Scatter Plot (Gambar 1.5).

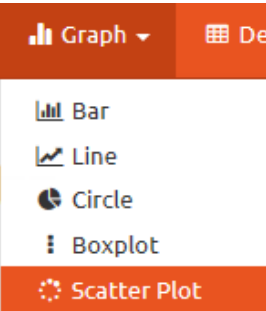

Gambar 1.5 Menu Scatter Plot

Perhatikan Gambar 1.6. Pilih menu Scatter Plot-V.

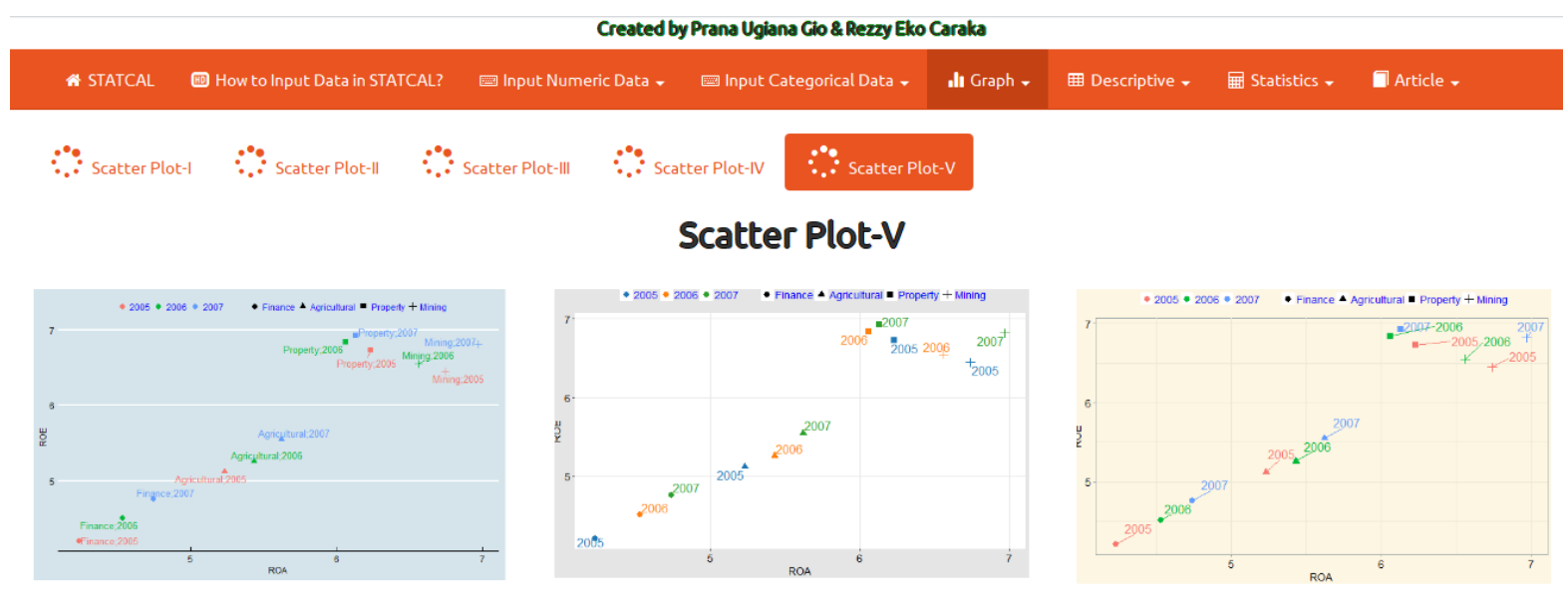

Gambar 1.6 Menu Scatter Plot-V

Lakukan pemilihan variabel seperti pada Gambar 1.7. 


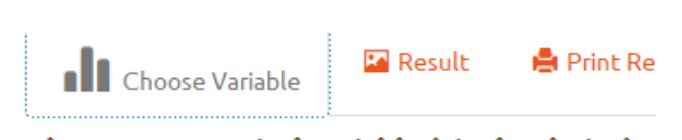

Choose Categorical Variable (Single Choice)
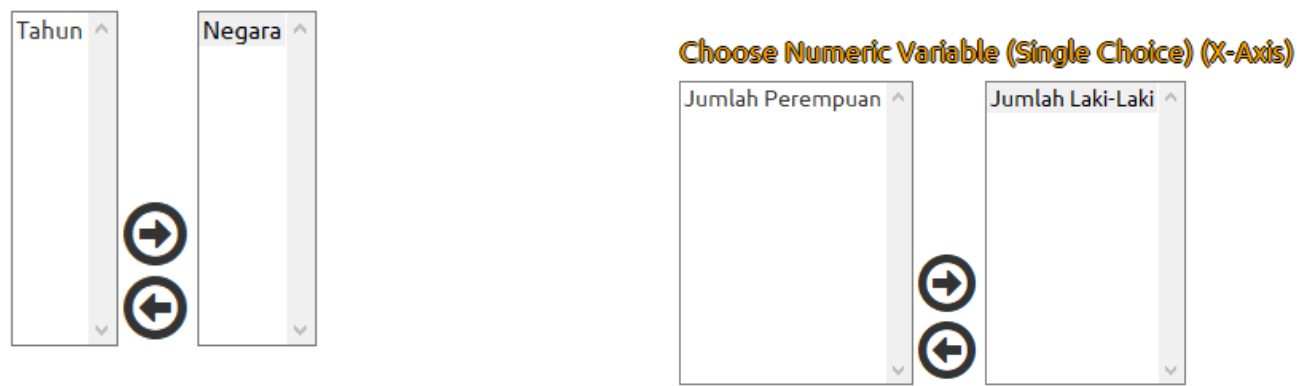

Choose Categorical Variable (Single Choice)

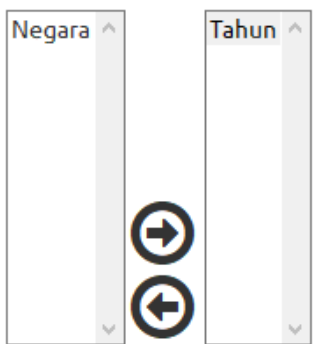

Choose Nuneric Variable (Single Choice) (Y-Axis)

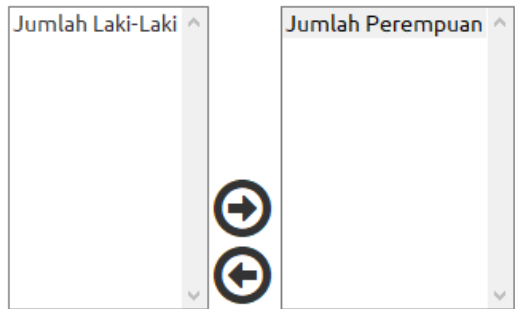

\section{Gambar 1.7 Pemilihan Variabel}

Hasil dari grafik sebaran data dapat dilihat pada bagian Result (Gambar 1.8).

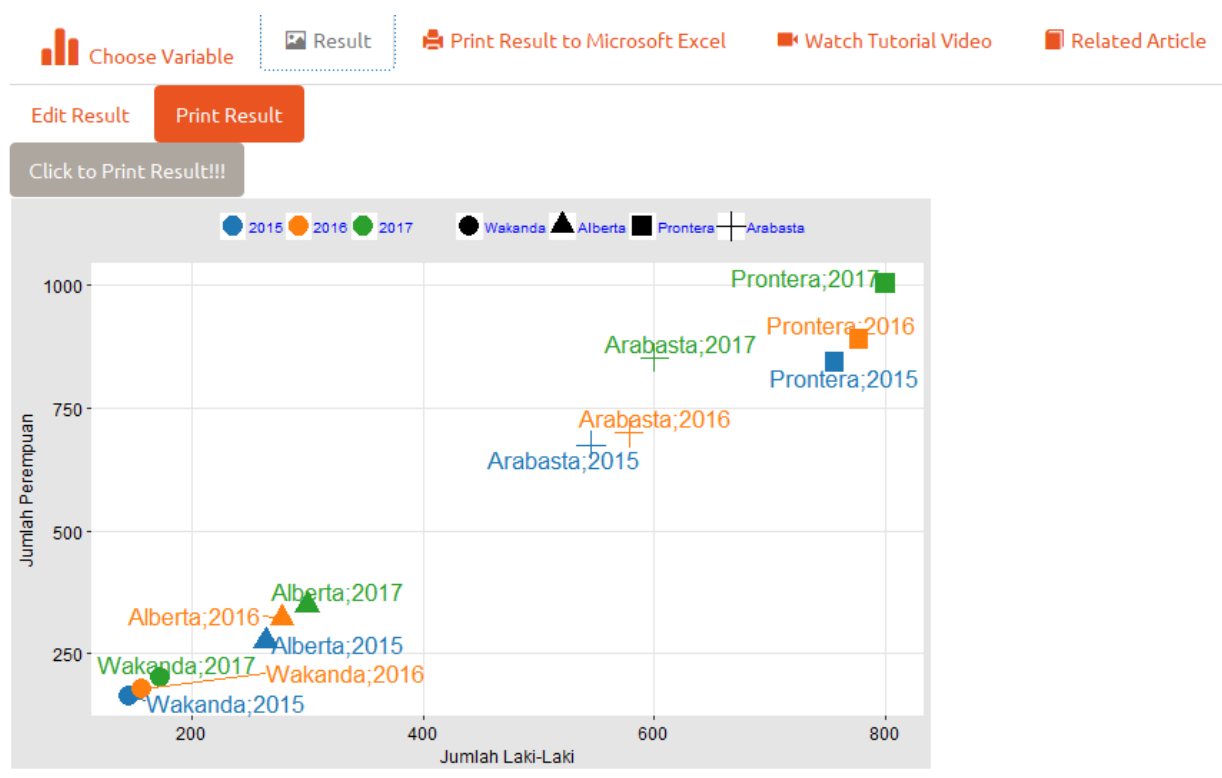

\section{Gambar 1.8 Result}




\section{Mengolah Data dengan}

Program Aplikasi Statistika
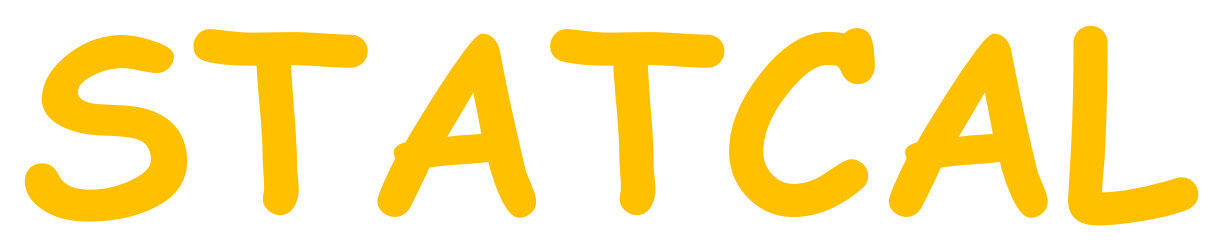

Membuat Grafik Time Series dengan Menu

Time Series-I

\section{Oleh Prana Ugiana Gio}

Founder \& CEO STATCAL

Created by Prana Ugiana Gio \& Rezzy Eko Caraka

Time Series I
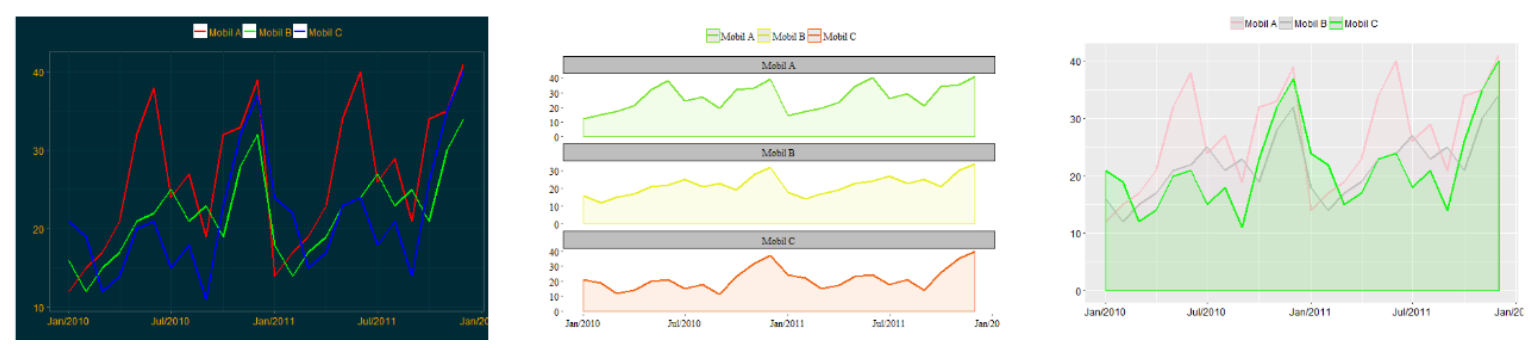
Pada pembahasan kali ini, akan dipaparkan bagaimana membuat grafik time series dengan STATCAL, menggunakan menu Time Series I. Misalkan diberikan contoh data hasil penjualan mobil A, B dan C mulai dari tahun 2010 sampai dengan tahun 2011 (Tabel 1.1).

Tabel 1.1 Jumlah Mobil A, B dan C yang Terjual dari Tahun 2010-2011

\begin{tabular}{|c|c|c|c|}
\hline Waktu & Mobil A & Mobil B & Mobil C \\
\hline 1-Jan-2010 & 12 & 16 & 21 \\
\hline 1-Feb-2010 & 15 & 12 & 19 \\
\hline 1-Mar-2010 & 17 & 15 & 12 \\
\hline 1-Apr-2010 & 21 & 17 & 14 \\
\hline 1-May-2010 & 32 & 21 & 20 \\
\hline 1-Jun-2010 & 38 & 22 & 21 \\
\hline 1-Jul-2010 & 24 & 25 & 15 \\
\hline 1-Aug-2010 & 27 & 21 & 18 \\
\hline 1-Sep-2010 & 19 & 23 & 11 \\
\hline 1-Oct-2010 & 32 & 19 & 23 \\
\hline 1-Nov-2010 & 33 & 28 & 32 \\
\hline 1-Dec-2010 & 39 & 32 & 37 \\
\hline 1-Jan-2011 & 14 & 18 & 24 \\
\hline 1-Feb-2011 & 17 & 14 & 22 \\
\hline 1-Mar-2011 & 19 & 17 & 15 \\
\hline 1-Apr-2011 & 23 & 19 & 17 \\
\hline 1-May-2011 & 34 & 23 & 23 \\
\hline 1-Jun-2011 & 40 & 24 & 24 \\
\hline 1-Jul-2011 & 26 & 27 & 18 \\
\hline 1-Aug-2011 & 29 & 23 & 21 \\
\hline 1-Sep-2011 & 21 & 25 & 14 \\
\hline 1-Oct-2011 & 34 & 21 & 26 \\
\hline 1-Nov-2011 & 35 & 30 & 35 \\
\hline 1-Dec-2011 & 41 & 34 & 40 \\
\hline
\end{tabular}

Berdasarkan data pada Tabel 1.1, diketahui pada 1 Januari 2010, mobil A terjual sebanyak 12 unit, mobil B terjual sebanyak 16 unit dan mobil C terjual sebanyak 21 unit. Gambar 1.1 
disajikan berbagai grafik time series mengenai jumlah mobil $\mathrm{A}, \mathrm{B}$ dan $\mathrm{C}$ yang terjual dari tahun 2010 hingga tahun 2011.

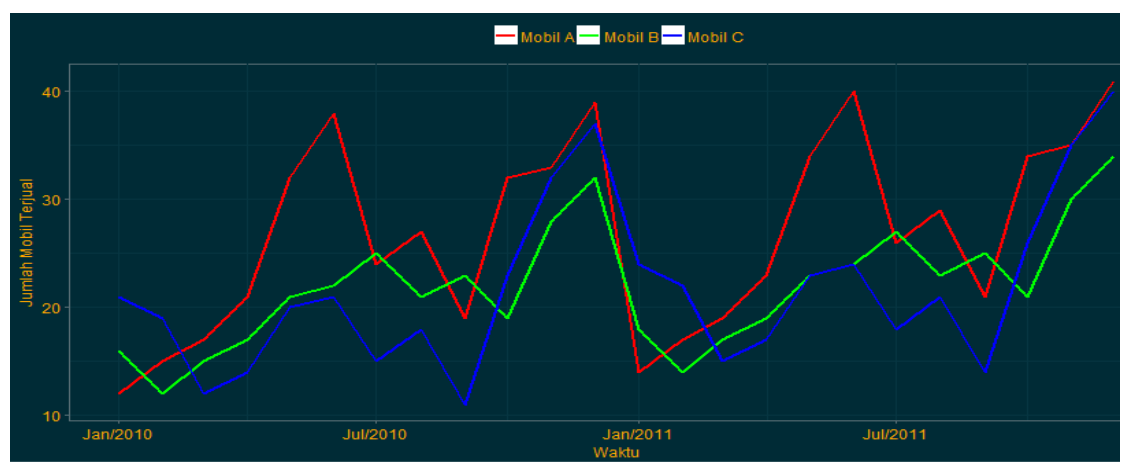

曰Mobil A
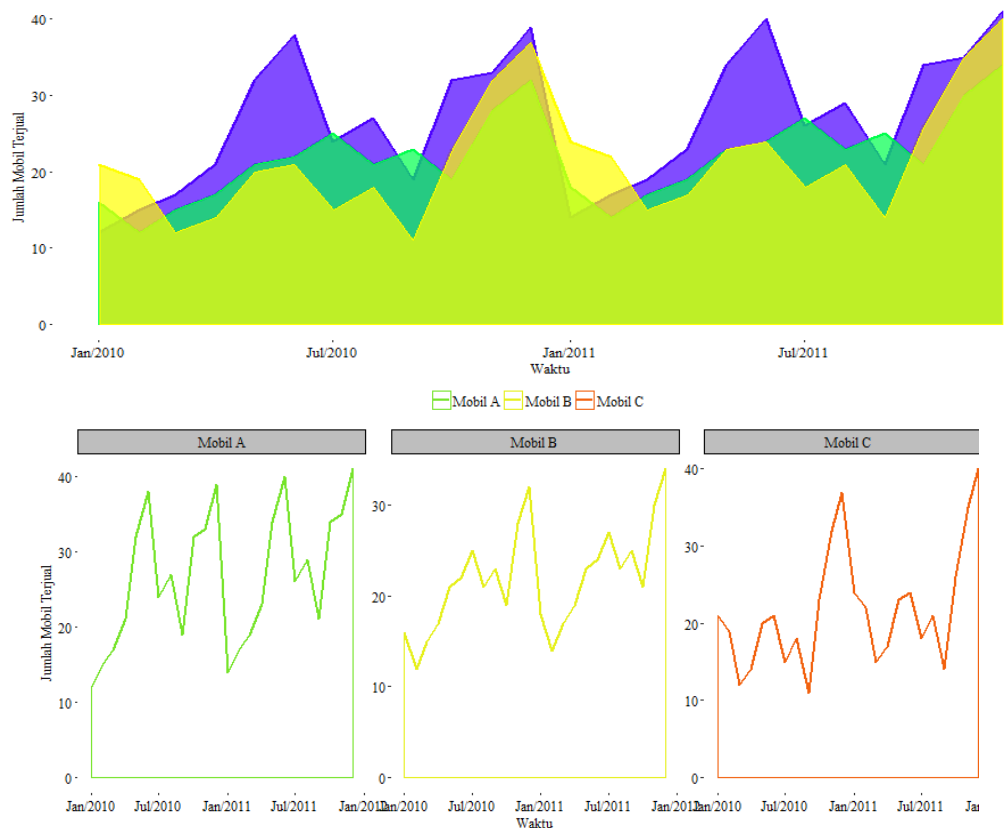

프리 A $=$ Mobil B - Mobil C

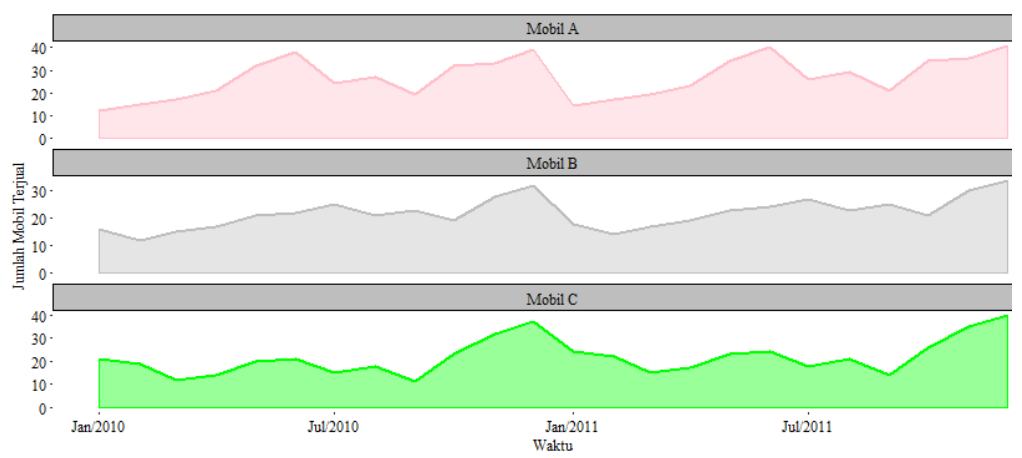

Gambar 1.1 Berbagai Grafik Time Series 
Untuk membuat grafik time series seperti pada Gambar 1.1, pilih Graph => Time Series (Gambar 1.2).

Created by Prana Ugiana Gio \& Rezzy Eko Caraka

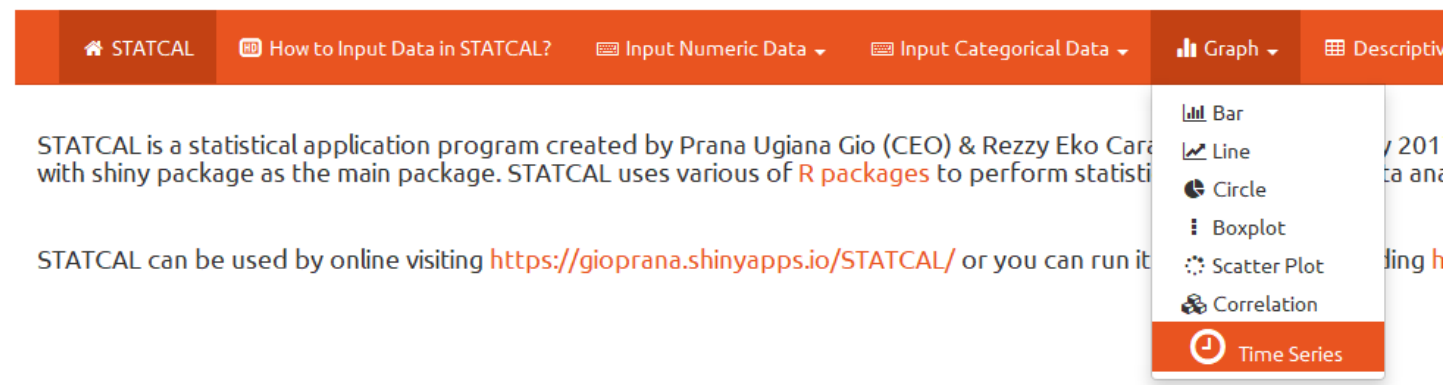

Gambar 1.2 Menu Time Series

Perhatikan Gambar 1.3. Pilih Time Series I.

Created by Prana Ugiana Gio \& Rezzy Eko Caraka

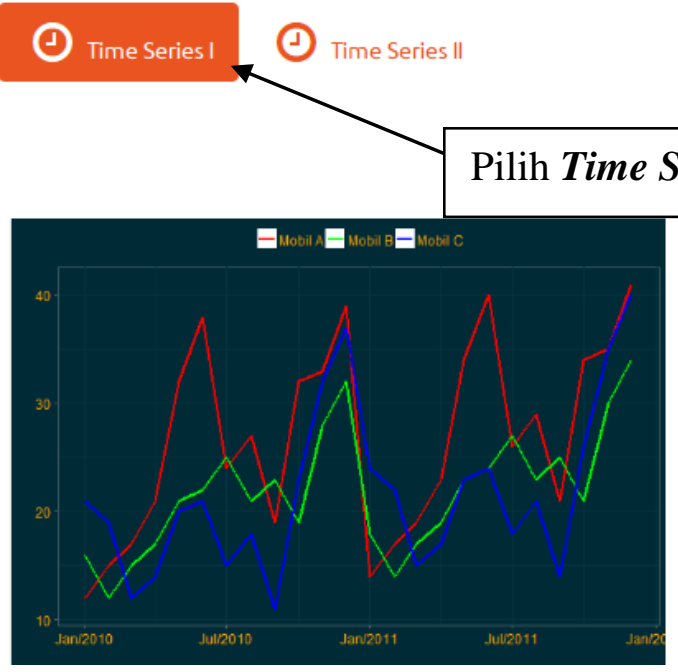

\section{Time Series I}

Gambar 1.3 Pilih Menu Time Series I 
Kemudian input data seperti pada Gambar 1.4, Gambar 1.5, dan Gambar 1.6.

\section{Input: Time (d-mm-yyy, example:}

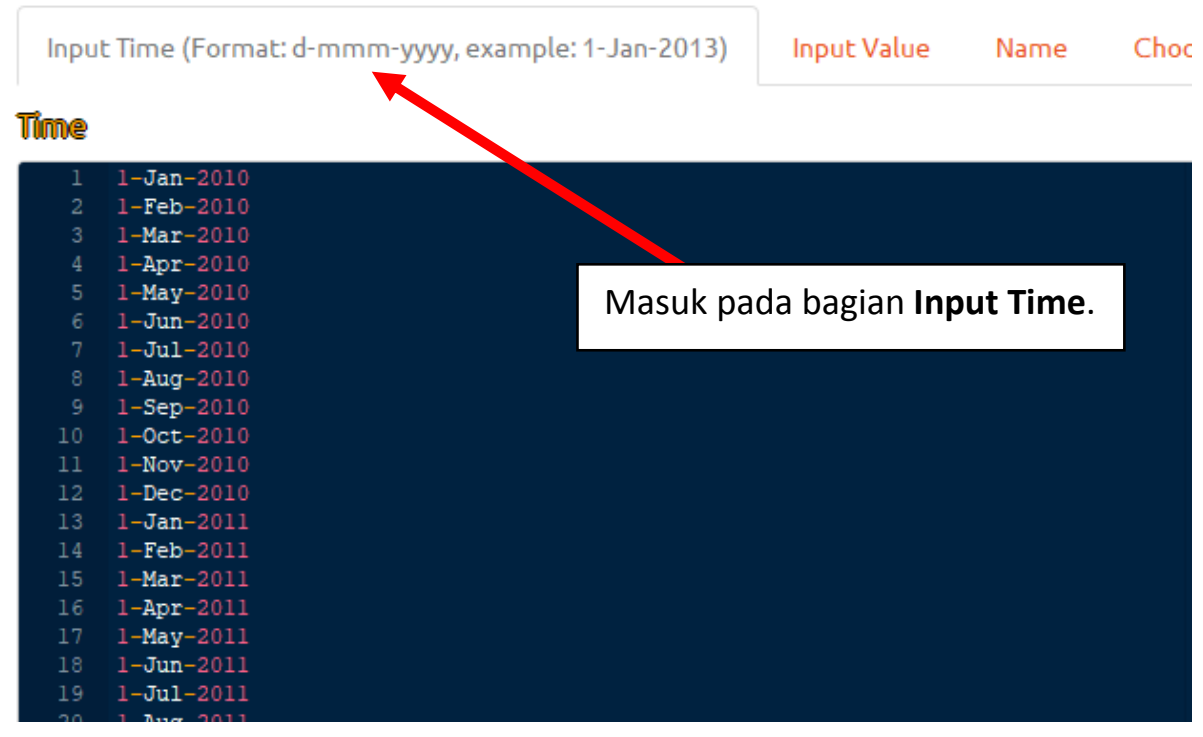

Gambar 1.4 Menginput Data Waktu

\section{Input: Time (d-mm-yyy, example: 1-DeI}

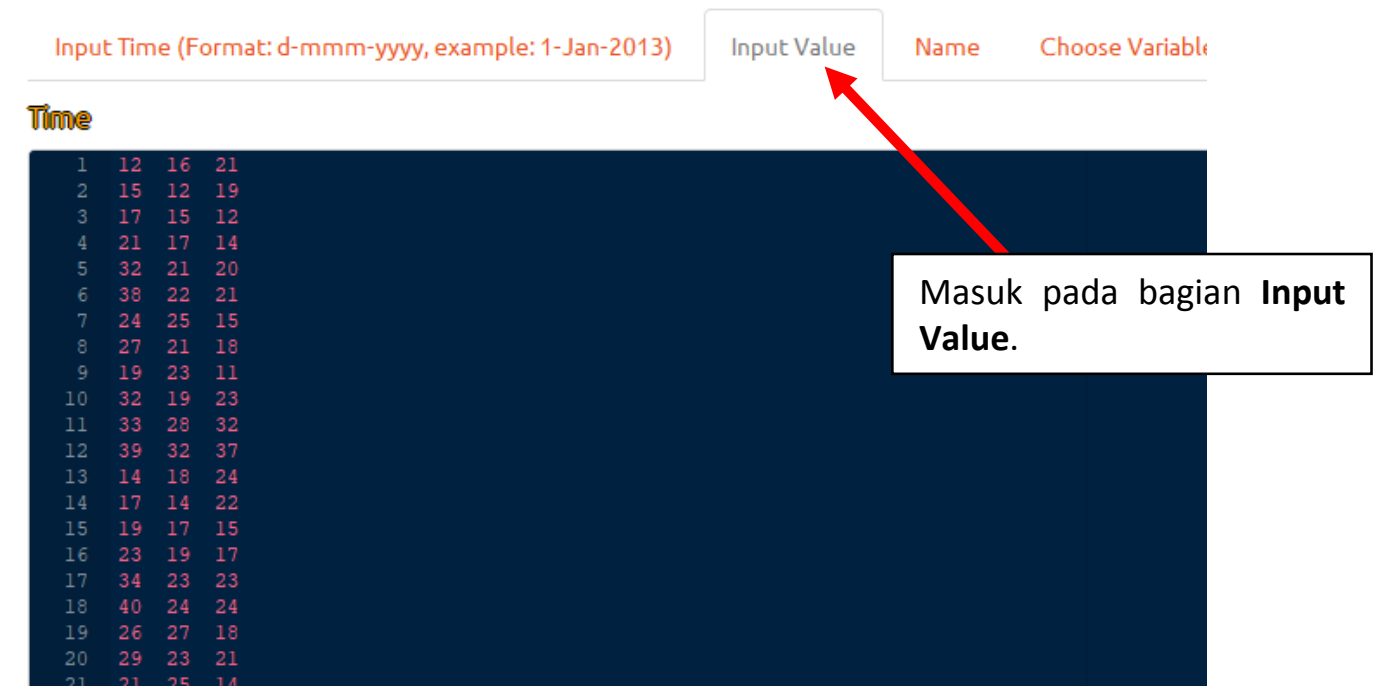

Gambar 1.5 Menginput Data Penjualan Mobil A, B dan C 


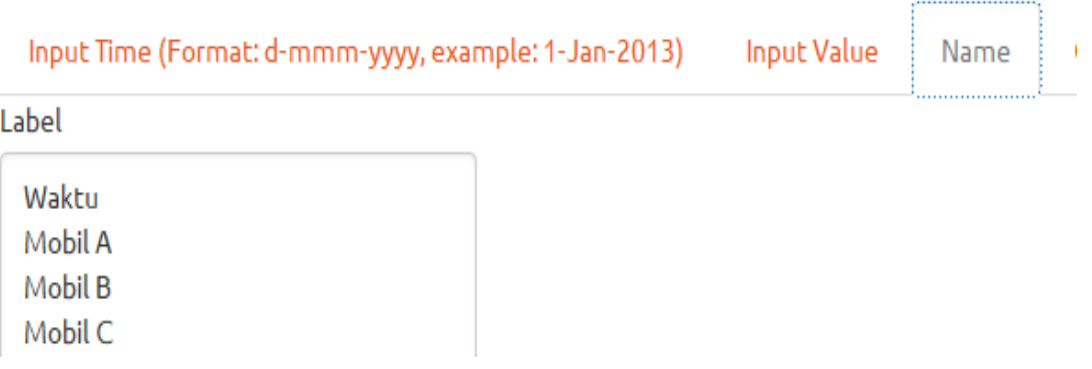

Gambar 1.6 Menginput Nama Variabel

Perhatikan Gambar 1.7. Pada Gambar 1.7, masukkan variabel mobil A, B dan C ke kotak sebelah kanan Choose Numeric Variable (Multiple Choices), sementara masukkan variabel waktu ke kotak sebelah kanan Choose Time (Single Choice).

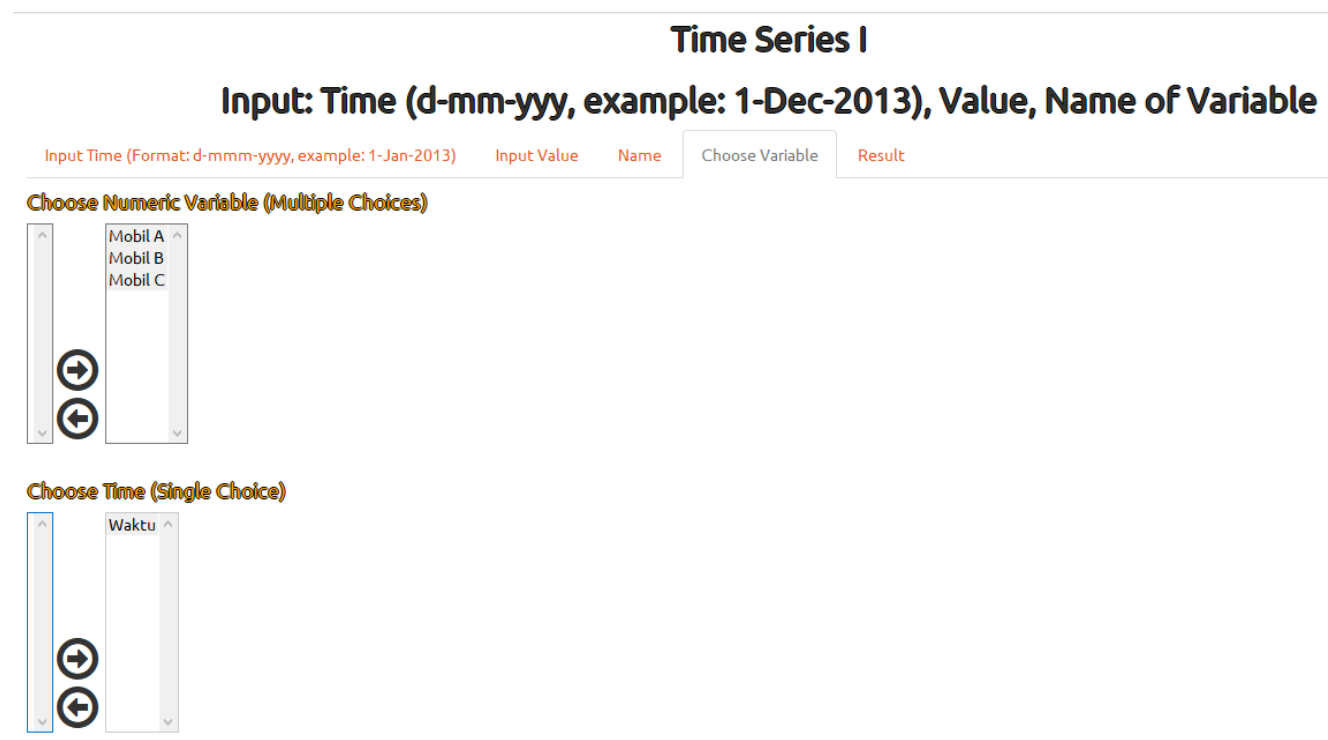

Gambar 1.7 Pemilihan Variabel

Hasil grafik time series I dapat dilihat pada bagian Result (Gambar 1.8). 


\section{Input: Time (d-mm-yyy, example: 1-Dec-2013), Value, Name of Variable}

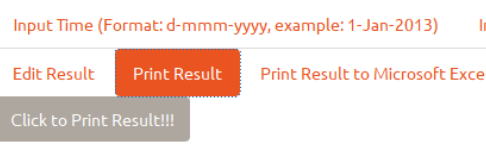

\begin{tabular}{ll|l} 
& \\
Input Value Name Choose Variable Result
\end{tabular}

Watch Tutorial Video

\section{Click to Print Result!!!}

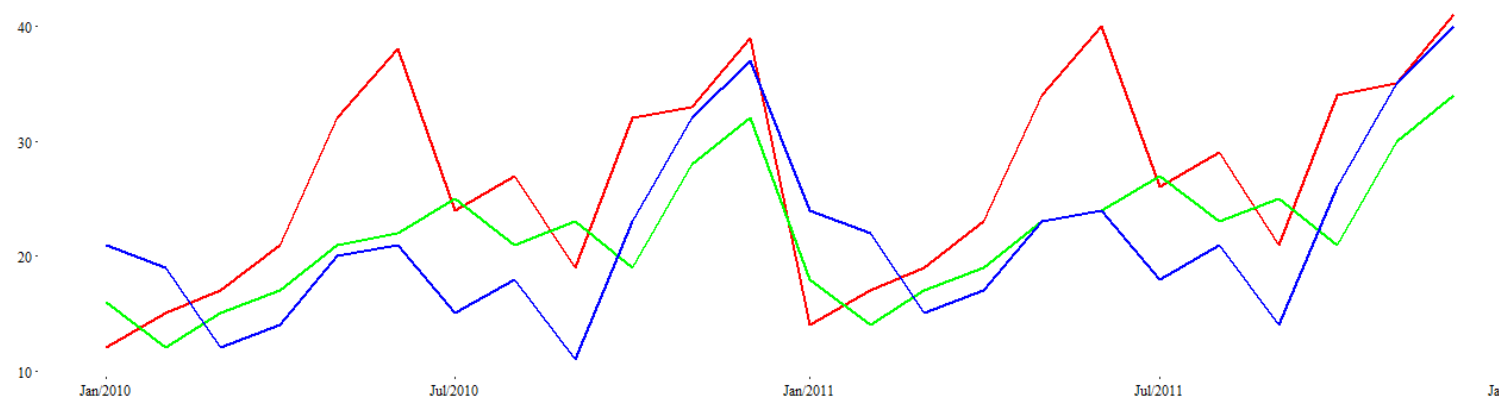

Input: Time (d-mm-yyy, example: 1-Dec-2013), Value, Name of Variable

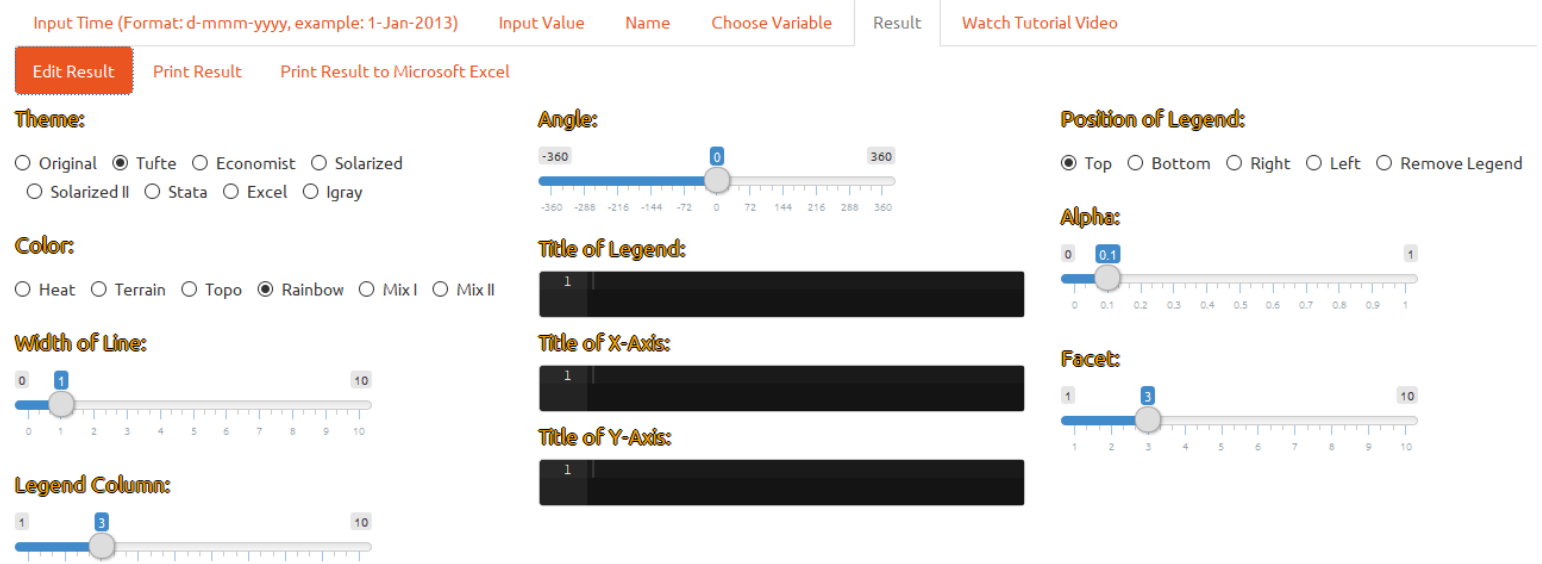

Gambar 1.8 Result 


\section{Mengolah Data dengan} Program Aplikasi Statistika
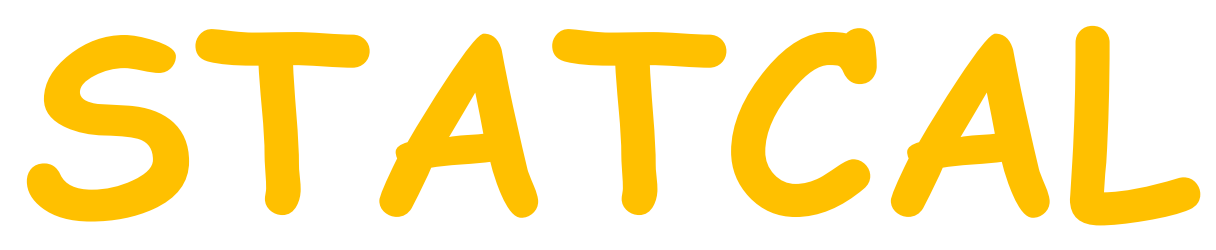

Membuat Grafik Time Series dengan Menu

$$
\text { Time Series-II }
$$

\section{Oleh Prana Ugiana Gio}

Founder \& CEO STATCAL

Created by Prana Ugiana Gio \& Rezzy Eko Caraka

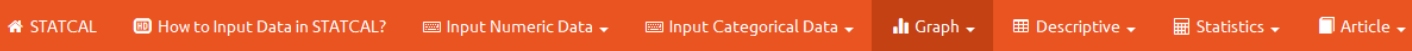

$$
\text { (1) Time Series1 (- Time Series II }
$$

Time Series II
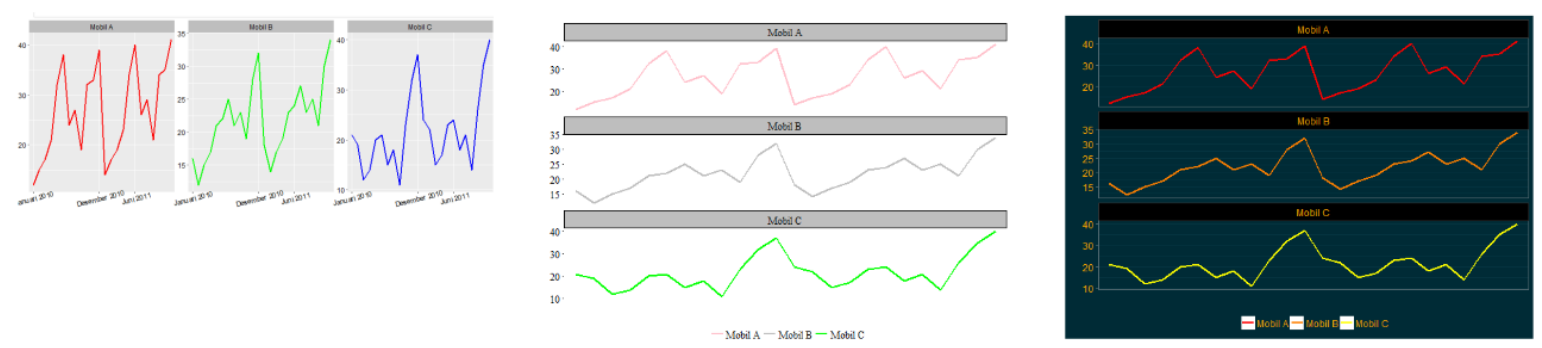
Misalkan diberikan contoh data hasil penjualan mobil A, B dan C mulai dari tahun 2010 sampai dengan tahun 2011 (Tabel 1.1).

Tabel 1.1 Jumlah Mobil A, B dan C yang Terjual dari Tahun 2010-2011

\begin{tabular}{|c|c|c|c|}
\hline Waktu & Mobil A & Mobil B & Mobil C \\
\hline Januari 2010 & 12 & 16 & 21 \\
\hline Februari 2010 & 15 & 12 & 19 \\
\hline Maret 2010 & 17 & 15 & 12 \\
\hline April 2010 & 21 & 17 & 14 \\
\hline Mei 2010 & 32 & 21 & 20 \\
\hline Juni 2010 & 38 & 22 & 21 \\
\hline Juli 2010 & 24 & 25 & 15 \\
\hline Agustus 2010 & 27 & 21 & 18 \\
\hline September 2010 & 19 & 23 & 11 \\
\hline Oktober 2010 & 32 & 19 & 23 \\
\hline November 2010 & 33 & 28 & 32 \\
\hline Desember 2010 & 39 & 32 & 37 \\
\hline Januari 2011 & 14 & 18 & 24 \\
\hline Februari 2011 & 17 & 14 & 22 \\
\hline Maret 2011 & 19 & 17 & 15 \\
\hline April 2011 & 23 & 19 & 17 \\
\hline Mei 2011 & 34 & 23 & 23 \\
\hline Juni 2011 & 40 & 24 & 24 \\
\hline Juli 2011 & 26 & 27 & 18 \\
\hline Agustus 2011 & 29 & 23 & 21 \\
\hline September 2011 & 21 & 25 & 14 \\
\hline Oktober 2011 & 34 & 21 & 26 \\
\hline November 2011 & 35 & 30 & 35 \\
\hline Desember 2011 & 41 & 34 & 40 \\
\hline
\end{tabular}

Berdasarkan data pada Tabel 1.1, diketahui pada Januari 2010, mobil A terjual sebanyak 12 unit, mobil B terjual sebanyak 16 unit dan mobil C terjual sebanyak 21 unit. Gambar 1.1 disajikan berbagai grafik time series mengenai jumlah mobil A, B dan C yang terjual dari tahun 2010 hingga tahun 2011. 
- Mobil A - Mobil B - Mobil C
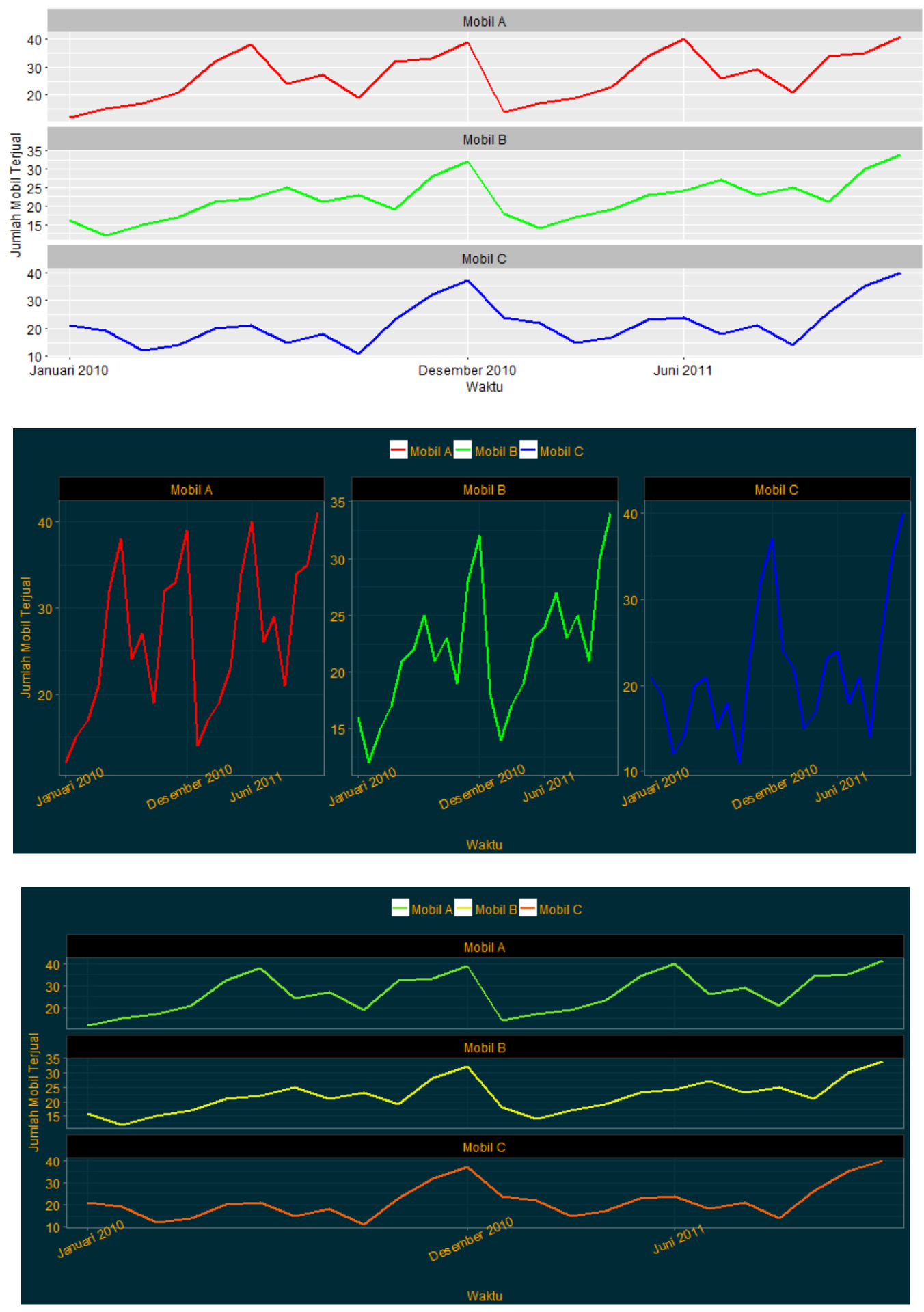

Gambar 1.1 Berbagai Grafik Time Series 
Untuk membuat grafik seperti pada Gambar 1.1, pilih Graph => Time Series (Gambar 1.2).

Created by Prana Ugiana Gio \& Rezzy Eko Caraka

\begin{tabular}{|c|c|c|c|}
\hline N STATCAL & How to Input Data in STATCAL? & all Graph v & 囵 Descriptiv \\
\hline \multirow{4}{*}{\multicolumn{2}{|c|}{$\begin{array}{l}\text { STATCAL is a statistical application program created by Prana Ugiana Gio (CEO) \& Rezzy Eko Cara } \\
\text { with shiny package as the main package. STATCAL uses various of R packages to perform statisti }\end{array}$}} & Llll Bar & \\
\hline & & L Line & 201 \\
\hline & & e Circle & ta anc \\
\hline & & : Boxplot & \\
\hline \multirow{3}{*}{\multicolumn{2}{|c|}{ STATCAL can be used by online visiting https://gioprana.shinyapps.io/STATCAL/ or you can run it }} & $\because$ Scatter Plot & ling $h$ \\
\hline & & Correlation & \\
\hline & & (อ) Time Series & \\
\hline
\end{tabular}

Gambar 1.2 Menu Time Series

Perhatikan Gambar 1.3. Pilih Time Series II.

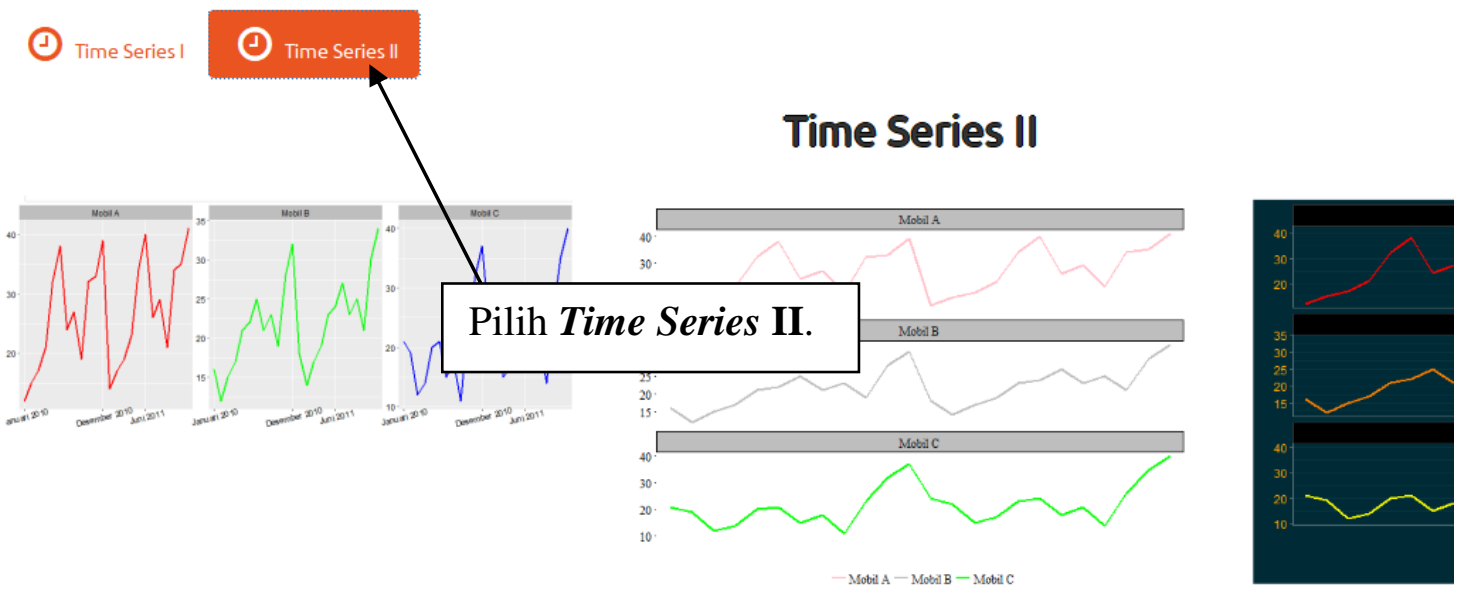

Gambar 1.3 Pilih Menu Time Series II 
Kemudian input data seperti pada Gambar 1.4, Gambar 1.5, dan Gambar 1.6.

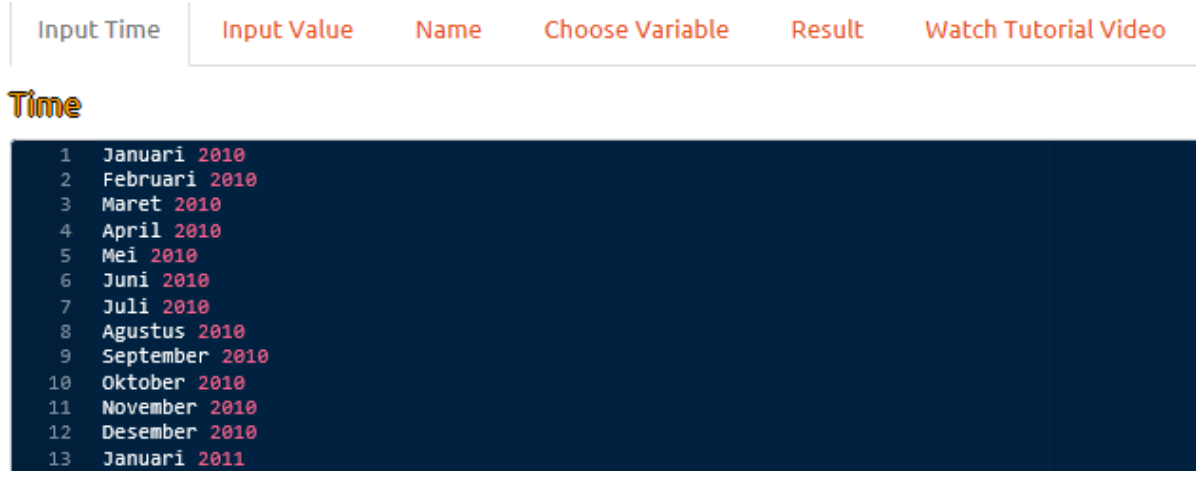

Gambar 1.4 Menginput Data Waktu

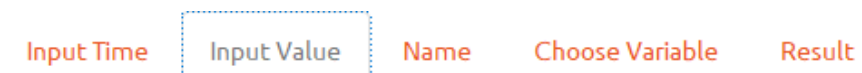

\section{Tักิกอ}

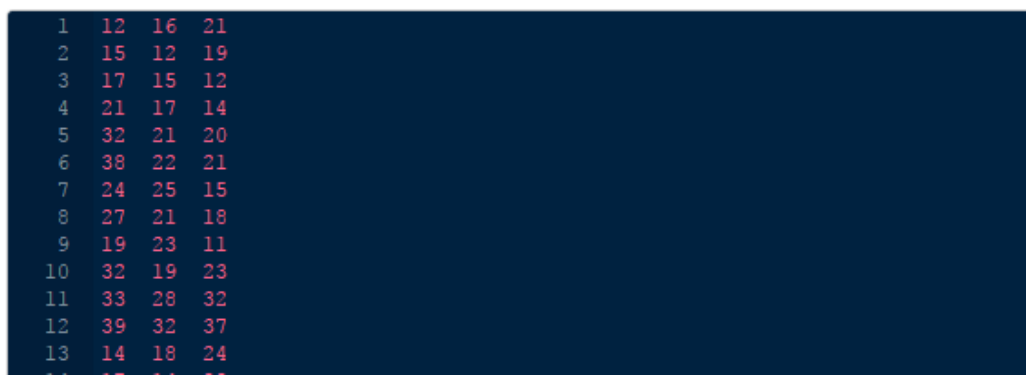

Gambar 1.5 Menginput Data Penjualan Mobil A, B dan C

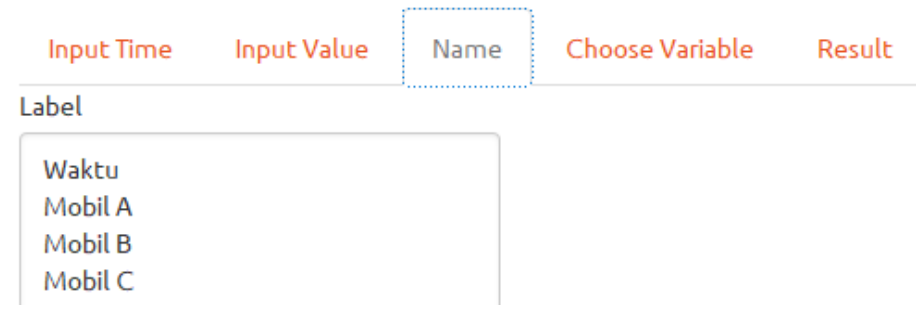

\section{Gambar 1.6 Menginput Nama Variabel}

Perhatikan Gambar 1.7. Pada Gambar 1.7, masukkan variabel mobil A, B dan C ke kotak sebelah kanan Choose Numeric Variable (Multiple Choices), sementara masukkan variabel waktu ke kotak sebelah kanan Choose Time (Single Choice). 


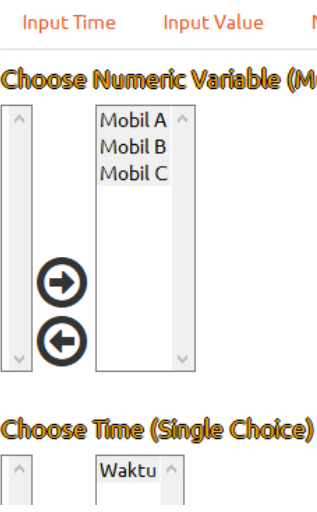

\section{Gambar 1.7 Pemilihan Variabel}

\section{Input: Time, Value, Name of Variable}
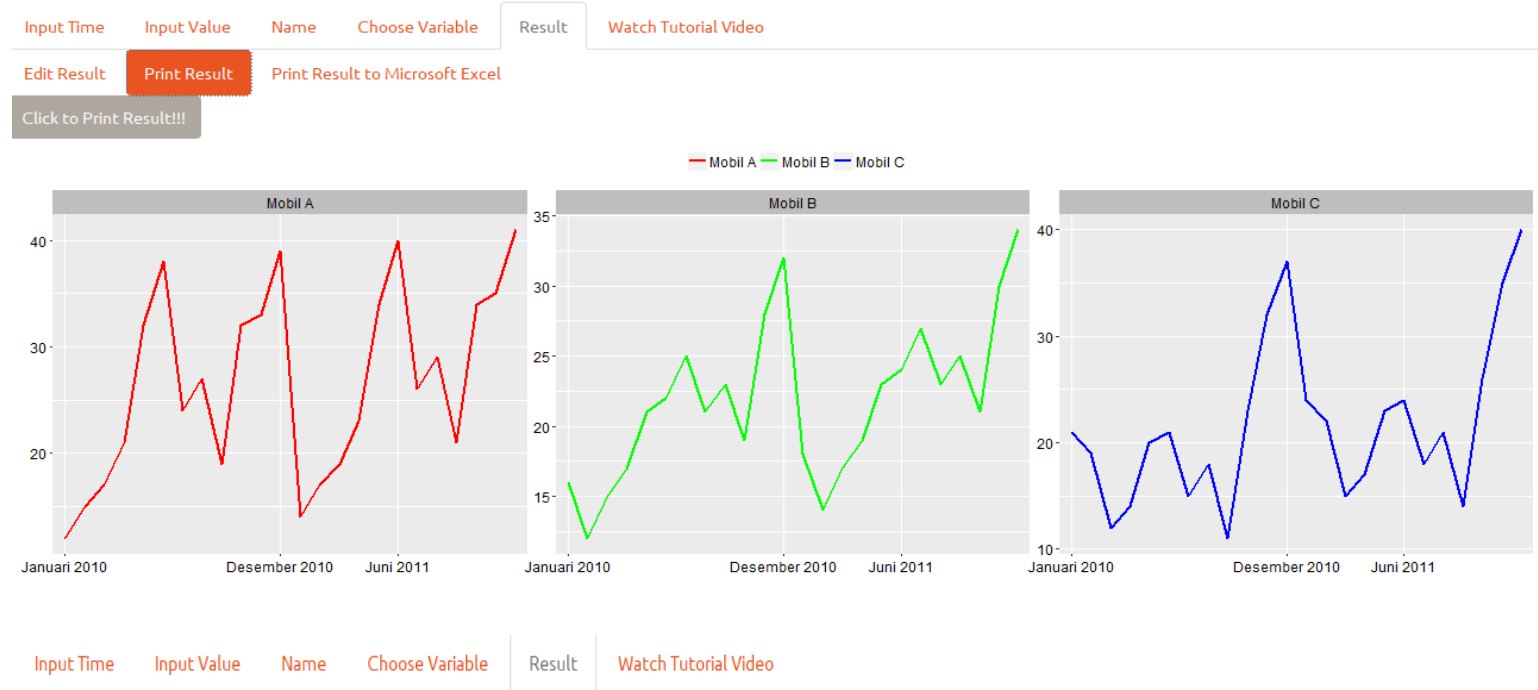

Edit Result Print Result Print Result to Microsoft Excel

\section{Theme:}

( ) Original $O$ Tufte $O$ Economist $O$ solarized

O Solarized $\|$ O Stata $O$ Excel $O$ Igray

Color:

O Heat $\bigcirc$ Terrain $\bigcirc$ Topo $\bigcirc$ Rainbow $\bigcirc$ Mix $\bigcirc$ Mix II

Whidth of line:

00

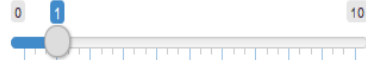

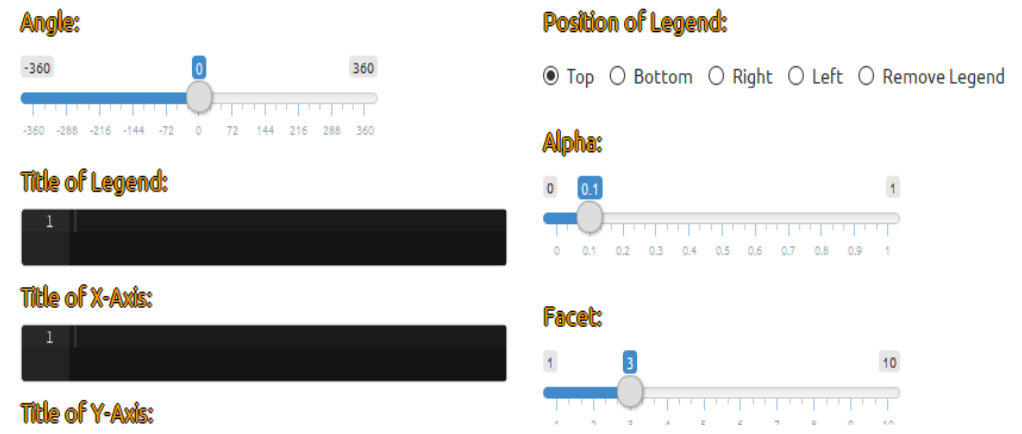

Gambar 1.8 Result

Hasil grafik time series II dapat dilihat pada bagian Result (Gambar 1.8). 
